Jana Javorčíková - Michael E. Dove

\title{
EXPLORATIONS IN AMERICAN LIFE AND CULTURE
}

Coursebook

Banská Bystrica

2021 
Authors: doc. PaedDr. Jana Javorčíková

Mgr. Michael E. Dove

Reviewers: $\quad$ prof. Ruslan Saduov, Ph.D.

doc. PhDr. Anna Zelenková, Ph.D.

Richard Amidon Betts, Ph.D.

Consulted experts: Mgr. Ivan Zelenka (The Composition of US Society), Mgr. Mikuláš Gürtler (The Legal System), Richard A. Betts, Ph.D., Michael Seward, Ph.D. (The Political System), Michael E. Dove (The School System), Sandra Hall, Ph.D. (The School System)

The university-level textbook Explorations in American Life and Culture, by doc. PaedDr. Jana Javorčíková, Ph.D. and Mgr. Michael E. Dove, is licensed under the Creative Commons 4.0 Attribution-No Derivative Works BY-ND.

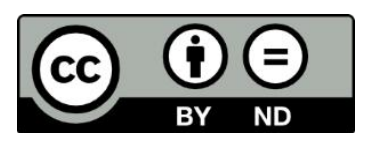

DOI https://doi.org/10.24040/2021.9788055718606

Cover design: $\quad$ Karol Demuth

Cover photograph: C Charles Hészely (Downtown Minneapolis)

Copyediting: $\quad$ Michael E. Dove; Chapters $2 \& 11$ : Paul Wood, Gloria M. Dove

Layout \& typesetting: Karol Demuth

Publisher: $\quad$ Belianum: Matej Bel University Press

Edition: $\quad 3$ rd edition

1 st electronic edition

Publication year: 2021

Format: A4

Page count: 236

ISBN９78-80-557-1860-6

(C) Javorčíková - Dove, 2021

Published in conjunction with research conducted as part of the grant KEGA 033UMB-4/2017: (Im)migration as a Political, Ethical, Linguistic and Cultural Phenomenon in the Era of Globalisation. 


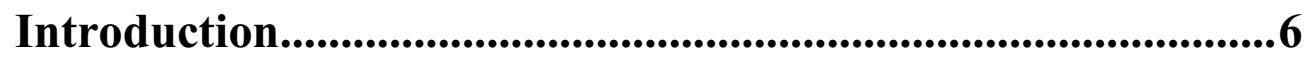

1 Methodological Basis - The Subject of American Studies.9

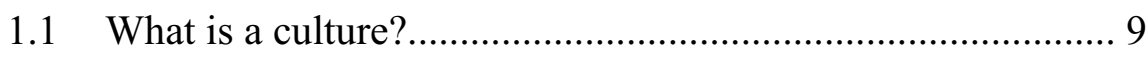

1.2 Why do linguists and philologists study culture?................. 10

1.3 What is cultural studies? What is American studies?............ 12

2 American Geography - the US Landscape Compared with Europe (by Michael E. Dove)........................................................................... 14

2.1 The USA within the Americas............................................. 14

2.2 The US Compared to Europe.............................................. 17

2.3 US Cities..................................................................... 19

3 Immigration to the USA - The Making of a "Nation of Immigrants" 26

3.1 Immigration to the USA in Dates....................................... 26

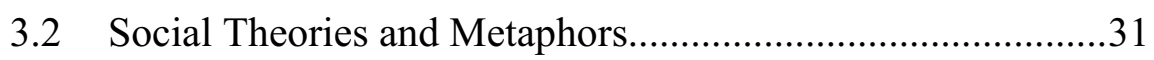

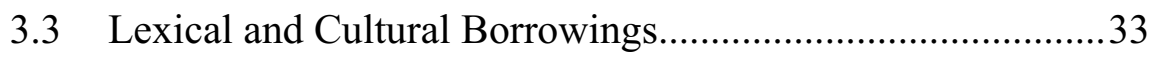

3.3.1 American English......................................................... 35

3.3.2 Borrowings from other cultures and languages.............. 38

4 The Composition of US Society............................................ 44

4.1 Who are the Americans? Popular St6ereotypes about the USA44

4.2 The American Majority and Minorities................................. 48

5 Institutions - The Political System.........................................55

5.1 Political Parties..................................................................... 54

5.1.1 Selected Historical Milestones of the US Political Parties54

5.1.2 Republican and Democratic Political Platforms Today..56

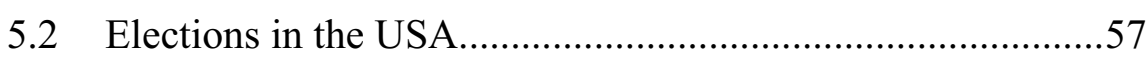

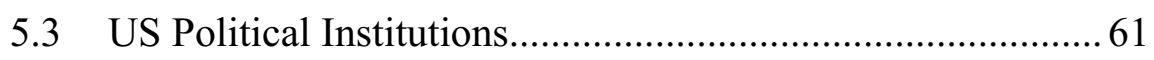

5.3.1 The Executive Branch...................................................61

5.3.2 The Legislative Branch..................................................62

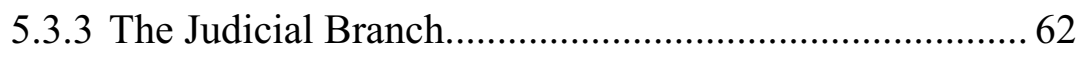

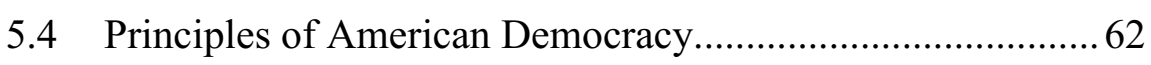

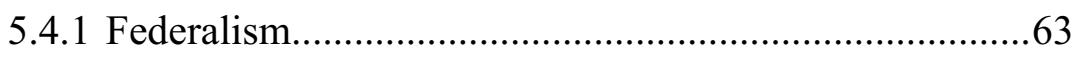

5.4.2 Separation of Powers - Checks and Balances................ 63 
5.4.3 Limited Government

5.4.4 Judicial Review. .65

6 The Economic System......................................................68

6.1 Historical Milestones in the US Economy............................68

6.2 Economic Schools and Famous Thinkers who have Influenced US Economic Thought. .72

7 The Legal System..............................................................

7.1 Basic Legal Documents....................................................... 76

7.2 The Constitutional Liberties and Famous Legal Principles... 79

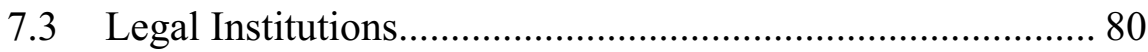

8 The School System.................................................... 83

8.1 Historical Milestones in US Education.................................83

8.2 Educational Principles of US Schools.................................... 85

8.3 Educational Philosophy of US Schools................................. 86

9 American Art........................................................................89

9.1 US Visual Arts (Painting and Sculpture).............................89

9.1.1 Historical Milestones in American Visual Art.............. 89

9.1.2 US Fine Arts in the 20th century.................................. 91

9.2 US Performing Arts - Theatre, Film, Music and Dance........92

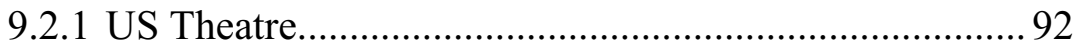

9.2.2 American Film and TV.............................................. 93

9.2.3 American Music and Dance.............................................93

10 Famous Holidays, Events and People............................. 96

10.1 Famous American Holidays.................................................96

10.1.1 Major holidays: religious holidays.............................. 96

10.1.2 Major holidays: political and patriotic holidays........... 98

10.1.3 Minor holidays: political and historical holidays......... 99

10.1.4 Minor holidays: unofficial and family holidays......... 100

10.2 Famous People in US History........................................... 101

11 Food and Agriculture (by Michael E. Dove).................... 109

11.1 What Americans (among others) eat: New World crops..... 109

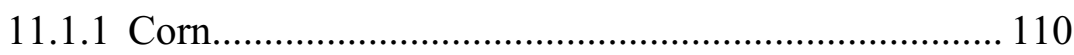

11.1.2 Selective breeding (continued).................................. 111

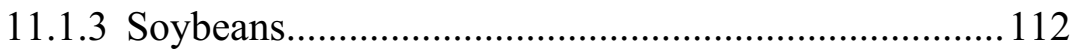


11.2 What Americans eat, revisited: Regional cuisines. 113

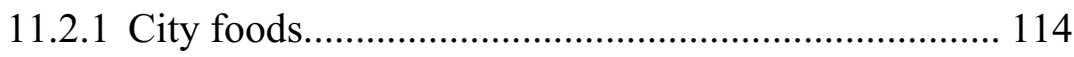

11.3 When Americans eat: Mealtimes........................................ 115

11.4 Where Americans eat....................................................... 116

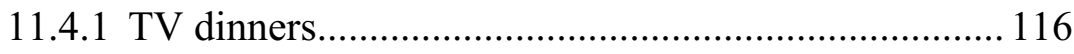

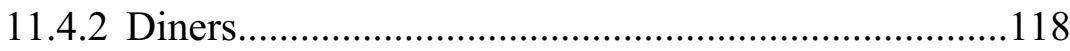

11.5 Some US/UK vocabulary differences................................. 120

12 US Regions (by Michael E. Dove)........................................122

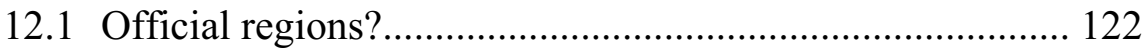

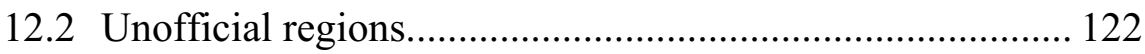

12.3 A brief tour of the US..................................................... 123

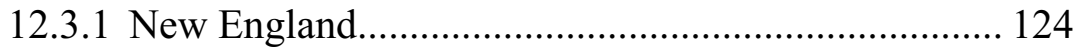

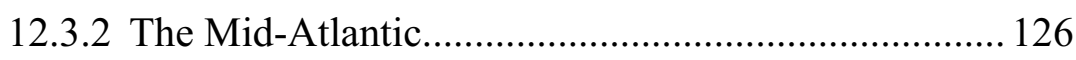

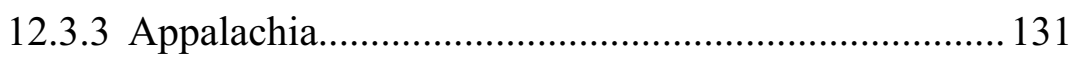

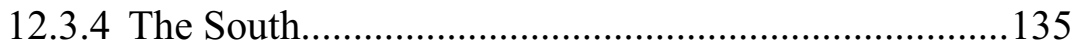

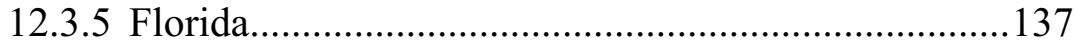

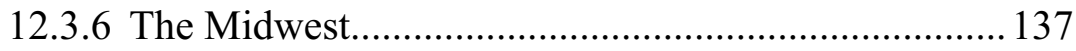

12.3.7 The Great Plains.......................................................... 140

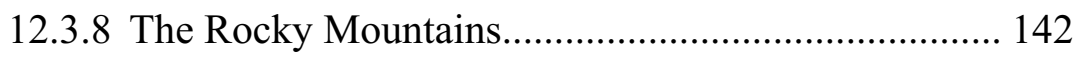

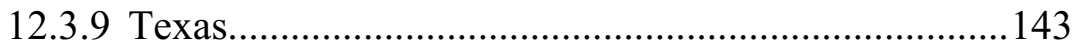

12.3.10 The Southwest.................................................... 144

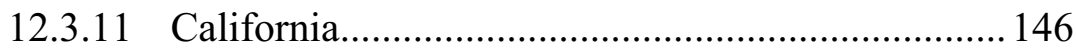

12.3.12 The Pacific Northwest.......................................... 151

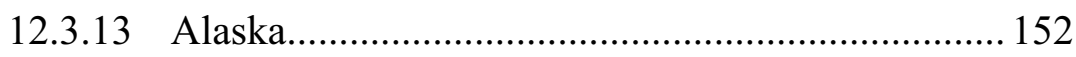

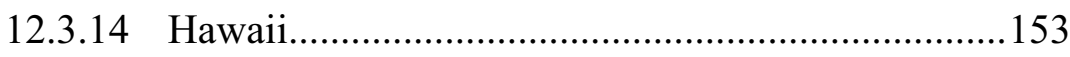

Appendix A The US Anthem............................................ 155

Appendix B US States, Capitals, Nicknames and the Etymology of Selected State Names............................................................................ 156

Appendix C I Have a Dream (extract)..............................159

Appendix D Sample Essay in American Studies.................163

Works Cited................................................................................167 


\section{Introduction}

It is impossible to learn a foreign language without acquiring the culture it embraces. Even by teaching the first words and the simplest conversational patterns, teachers perpetuate different cultural concepts and modes of behaviour. For example, the basic concept lunch has a very different meaning in Slovakia (where it usually means a two-dish meal, served at a table), in Britain (where it could refer to a bag of vinegar-flavoured crisps) and in the USA (where it often means a quick stop at Subway or Chipotle). A response to the question How are you? also differs from country to country. In some countries, the only socially acceptable answer is simple and pre-formatted (I'm fine); in others it is almost impolite not to go into great length, and not to mention individual members of one's family, their medical condition, job and social life. Thus, proper functioning in the new culture might be even more important than mere mastering the linguistic rules of a foreign language.

Needless to say, such social competencies expand regular day-to-day informal situations. In business, closing a contract often depends on prompt, properly formulated and culturally sensitive reactions to various proposals. Interpreters also greatly profit from cultural awareness; they often function not only as transmitters of the discourse but also as cultural "bridges", merging two or more different cultures. For example, the direct and brief answer "no" may in some cultures sound impolite and disrespectful. It is the interpreter's task to re-formulate it into a socially more palatable style and form of response.

A competent language speaker has to be both "languagewise" and "culturewise" in order to understand the multiple forms of use of a foreign language in various unrehearsed situations and to be able to react spontaneously yet appropriately. Therefore some scholars speak about "the art of crossing cultures." Whether culture can be taught is an unresolved question. Some believe acquiring a new culture is a life-long process. The aim of this coursebook is ambitious; it attempts to provide information related to many areas of daily life in the USA such as politics, economics, law, education and arts, to name a few, including necessary vocabulary accompanied by Slovak translations and explanations. The coursebook, however, is not all-inclusive; students are welcomed to extend their competence via recommended web-pages and sources. It is the hope of the authors that students will develop a passion for learning new facts about the USA, but also an academic and objective attitude and tolerance towards new cultures which they would further disseminate to their students and peers. Teaching and learning cultural studies should promote better understanding among people and nations, not only by learning about differences, but also the similarities that connect them.

I would like to express my gratitude to all who contributed to this coursebook, by written text, advice, inspiration or understanding its importance. These include:

- Richard Betts, PhD., who lectured on American studies at Matej Bel University from 1997 to 2008 and who helped to enrich the American Studies programme at the Department of English and American Studies by student and teacher exchanges, book donations and visiting lectures;

- Michael E. Dove, who currently co-teaches American studies at Matej Bel University and who contributed this book's entire geographical and food sections;

- Sandra Hall, PhD., a great teacher and fighter for high-quality education about the US for all;

- Jane Norman, a fellow traveller who showed me the most remarkable places in the USA;

- Ivan Zelenka, who taught culture and literature of the English-speaking world at Matej Bel University and helped to build the department of English from the very beginning;

- The Fulbright Foundation, which allowed me to explore American culture and teach at Minneapolis Community and Technical College in 2005 and 2006;

- The Transatlantic Grant, awarded in 2001 and the ACFR Grant awarded in 2006, which allowed me to travel the USA and gather invaluable materials for this coursebook. 
Among the many people who made this book possible, I would like to thank artist Christophe Chabert (MSc. in International Management and Economics, HEC Business School) for granting us his permission to use his handsome map of Silicon Valley (p. 149).

Michael E. Dove 


\section{How to Use This Book}

Each chapter starts with a set of introductory questions that are directly or indirectly answered in that chapter. New vocabulary is presented in the grey box at the beginning of each chapter. However, some words are not directly mentioned in the text of the chapter; students are to look up these individually.

Some cultural studies terminology and related vocabulary is difficult to translate into Slovak, so the Slovak translation of the more complicated terms are included in brackets (usually in italics and indicated by the abbreviation "SK") when we feel they facilitate understanding of the issue in question.

The coursebook is primarily aimed at Slovak students of American studies; therefore, many data or phenomena are compared to those in Slovakia. Nevertheless, the text is also understandable to those who are not acquainted with Slovak "realia" and who want to extend their knowledge of American culture.

As the book is designed to stimulate discussion, each chapter is accompanied by a Follow-up section in which one or several sets of questions are suggested for pair or group work or classroom discussion.

Note: The sections written by Michael E. Dove use American English. The sections written by Jana Javorčíková use British English. 


\title{
1 Methodological Basis - The Subject of American Studies
}

In this chapter you will learn:

- What is a culture? The etymology and history of the term.

- Why do linguists and philologists study culture?

- What is cultural studies? What is American studies?

\author{
Study and explain the following terms: \\ culture \\ intercultural \\ languagewise, culturewise \\ cultural studies \\ cultural effectiveness \\ American studies \\ minimum content
}

\subsection{What is a culture?}

Etymology and history of the term: Etymologically, the word "culture" comes from the Latin word cultura, meaning cultivation, improvement and enrichment. Cicero, a Roman philosopher, political theorist and orator, is believed to be the first to use the phrase "cultivation of the soul" (cultura animi) in his Tusculanae Disputationes (45 BC) in the metaphorical sense of the word.

In modern times, Cicero's original use of the term "culture" has been extended to "all the ways in which human beings overcome their original barbarism, and through artifice, become fully human." Nowadays, the term "culture" encompasses the teachings of many theorists and philosophers (e.g. Jean Jacques Rousseau and Emanuel Kant). In common speech "culture" usually refers to (1) identity (e.g. of a region, group of people, nation) or (2) cultivation of the original, authentic "self".

Culture, however, is also a subject of professional research for many disciplines such as anthropology (the study of mankind, its origins, development and customs), ethnology (the study of different ethnicities), sociology, political sciences and many others.

Modern definitions of "culture": Some scholars recognize over 200 definitions of the term "culture". Let us explore three of these - a linguistic (dictionary) definition, a sociological definition and a political definition:

1. Dictionary definition: A. S. Hornby (1989): "Culture [means]:

1.1 ...a refined understanding and appreciation of art, literature, etc. (for example: a university should be a centre of culture).

1.2 ...the state of intellectual development of a society (for example: mass culture, 20th-century culture).

1.3 ...a particular form of intellectual expression, e.g. in arts and literature (for example: Greek culture).

1.4 ...the customs, arts, social institutions, etc. of a particular group of people (for example: Eskimo culture)". 
2. Sociological (anthropological) definition: R. Murphy (1986): "Culture means the total body of tradition borne by a society and transmitted from generation to generation. It thus refers to the norms, values, and standards by which people act, and it includes the ways distinctive in each society of ordering the world and rendering it intelligible. Culture is [...] a set of mechanisms for survival, but it provides us also with a definition of reality. It is the matrix into which we are born, it is the anvil upon which our persons and destinies are forged."

3. Political definition: The official UNESCO definition (2002): “...culture should be regarded as the set of distinctive, material, intellectual and emotional features of society or a social group, and that it encompasses, in addition to art and literature, ways of living together, value systems, traditions and beliefs."

The changeable nature of culture: All these definitions - linguistic, sociological and political broaden the core of the term "culture" from their own perspective. Thus, studying culture from a political perspective (focused on fundamental documents, institutions and mechanisms of the examined society) inevitably differs from studying the same culture from the perspective of literature, education or the fine arts.

Not only the focus of attention of cultural studies but also the method of acquiring cultural information differs from other academic subjects. According to Michael Byram, the study and acquisition of culture includes information gathered consciously (by learning, practicing), but also subconsciously (by experience, imitating). Byram writes that mastering culture reaches "from the commonest greetings through use of public services [...] non-verbal behaviour, and the expectations of conversation turn-taking, rules of politeness and the maxims of normal communication", and is as significant for successful communication as the native speakers' conscious knowledge (historical, geographical, sociological, etc.) about their society along with linguistic knowledge. (Ibid.).

What is more, some scholars point out that culture is not an "invariate and static entity made up of accumulated, observable, thus eminently teachable and learnable facts but a variable entity, changing with times and new social phenomena". As a result, cultural studies differs from all other academic disciplines: its subject of research is interdisciplinary and modified by the purpose of the study; unlike other disciplines, cultural studies examines both conscious and unconscious cultural knowledge of the target country and its inhabitants, and the focus of research is changeable and needs perpetual updating.

\subsection{Why do linguists and philologists study culture?}

Studying foreign languages inherently incorporates the study of culture of the respective language. In this observation we rely on the research of Michael Byram, who observes that language has no function independent of the context in which it is used, and thus always refers to something beyond itself: the cultural context. Slovak scholars Otrísalová and Gazdík also observe that "translations are not made in a vacuum but arise in a given culture at a given time." Here are some examples:

- Historical and geographical cultural context: The lexica of many languages contain words that have rich and interesting historical backgrounds. Many of these words were originally borrowed from other languages and, therefore, often lack a Slovak (or European language) equivalent. For example, the first settlers in America borrowed many Indian words (mostly referring to regional flora, fauna and the way of life in America) which completely lacked any equivalent in Slovak (or any other European language). Instead of being translated, the original word has been used up to the present. For example: catalpa (a Catawba Indian word for a specific plant) is referred to in Slovak as katalpa obyčajná. Mere translation thus does not help to understand the meaning of the word; we need to learn more about American flora to know its shape, colour, flavour and use.

- Linguistic-cultural context (grammatical, phonetic, morphological etc.: As the English language "travelled" across oceans to America, Australia, Africa and many other regions of the world, many 
grammatical, phonetic, morphological and other types of changes occurred. For example, the pronunciation of the final " $r$ " sound in the word "car" depends on the region where the word is used. Morphological and lexical changes also occurred, both internationally and nationally. For example, in most of the USA you stand in line but in New York you stand on line.

- Social-cultural context: mastering a foreign language means more than mastering its linguistic rules. As Ivan Zelenka notes, it is equally important to master the "culturewise" level of the language. That incorporates many verbal and non-verbal elements (including proximity, gestures and movements, facial expressions and many others), social skills, codes and taboos, for example:

- proximity: how close people stand to each other,

- how loudly or softly someone speaks;

- when to and when not to make eye contact;

- socially acceptable and inacceptable topics for formal/informal situations;

- formulations of excuses, how to respond to feedback;

- how directly or indirectly one may ask for help or clarification of instructions, how to treat people of a different gender, sexual orientation, race, culture or age;

- how to say no;

- in what manner (tone, pitch, style) to criticize or praise other people's performance;

- when to be casual and when to be formal;

- how to interpret the meaning of others' behaviour.

Mastering non-verbal communication is also essential for successful use of a foreign language. $\mathrm{R}$. M. Paige introduces the term "cultural effectiveness", referring to one's ability to function in the foreign culture. That is the major aim of students of cultural studies.

\subsection{What is cultural studies? What is American studies?}

The Gist of Culture Learning: Paige and Jorstad define culture learning as "the process of acquiring the culture-specific and culture-general knowledge, skills, and attitudes required for effective communication and interaction with individuals from other cultures. It is a dynamic, developmental, and ongoing process which engages the learner cognitively, behaviourally, and affectively."

The Subject of Cultural Studies: Cultural studies (in Europe also known as "realia courses" and country studies) is an interdisciplinary subject that integrates information from many fields of research, such as sociology, politics, economics, geography, history, and the arts, as well as literature, philosophy, law, photography, gender studies and many others.

In 1994, Byram formulated what he called minimum content, i.e. the minimal scope of culture-based information and data that would provide the learner with the minimum necessary extent of data needed to successfully function in a new culture. These are:

a) social identity, social groups (age, sex, class, region, profession);

b) social interaction (verbal and non-verbal behaviour, familiarity);

c) faith and behaviour (routine, natural group behaviour, moral and religious faiths);

d) social and political institutions (state institutions and their values, law, health care);

e) social and public life (family, schools, professions, religion, military service);

f) national history (including present and historical events that are regarded as important by the members of the society); 
g) national geography;

h) national cultural heritage;

i) stereotypes and national identity (roots for stereotypes, their comparison).

American studies is thus an interdisciplinary field that explores many areas of American political, social, cultural and daily life. American studies does have its own terminology (e.g. the term Americanization); however, it also borrows some terminology and research methods from other disciplines such as law, economics, political sciences, arts, and many others.

French Americanist Marc Chenetier, however, warns against merely accumulating data from various fields; instead he advocates the internalization of cultural studies and the necessity of a comparative approach. The authors of this coursebook, in accordance with notable Slovak and international scholars, also understand cultural studies as an interdisciplinary and comparative discipline, exploring a broad scope of USA-related data such as main historical and political events, the structure and functioning of fundamental institutions and organizations, the significance of major American documents, artistic, literary and technological achievements, nationally recognized holidays, famous American people in history and many other areas. Understanding these concepts will help the students to better and more competently use the English language in practical use as well as in translating.

\section{Follow-up}

1. Discuss the following statements. Do you agree, partly agree or disagree? Explain why:

\begin{tabular}{|l|l|l|l|l|}
\hline & AGREE & $\begin{array}{c}\text { PARTLY } \\
\text { AGREE }\end{array}$ & DISAGREE \\
\hline a) & $\begin{array}{l}\text { What seems to be logical, sensible, } \\
\text { important and reasonable to a person in } \\
\text { one culture may seem stupid, irrational } \\
\text { and unimportant to an outsider. }\end{array}$ & $\begin{array}{l}\text { When people talk about other cultures, } \\
\text { they tend to describe the differences and } \\
\text { not the similarities. }\end{array}$ & $\begin{array}{l}\text { Personal observations and reports of } \\
\text { cultures should be regarded with a great } \\
\text { deal of scepticism. }\end{array}$ & $\begin{array}{l}\text { It is probably necessary to know the } \\
\text { language of a foreign culture to } \\
\text { understand the culture in depth. }\end{array}$
\end{tabular}

2. Discuss the values and priorities expressed in the US anthem (for the full text, see Appendix A). 


\section{American Geography - the US Landscape Compared with Europe (by Michael E. Dove)}

This is a new nation, based on a mighty continent, of boundless possibilities.

(Theodore Roosevelt)

In this chapter you will learn:

- What are some of the geographical similarities and differences between the USA and Europe?

- How is the USA's population distributed?

- What is unique about US cities?

$\begin{array}{ll}\text { Study and explain the following terms: } & \\ & \\ \text { the lower } 48 \text { states } & \text { high-rise } \\ \text { the Gulf Stream } & \text { skyscraper } \\ \text { population density } & \text { skyline } \\ \text { rural } & \text { white-collar } \\ \text { urban } & \text { urban sprawl } \\ \text { downtown } & \text { suburb } \\ \text { financial district } & \text { highway } \\ \text { commute } & \end{array}$

\subsection{The USA within the Americas}

\section{The American Continent(s)?}

In a textbook intended for university students, one might think we could skip a discussion of Earth's continents. But even in such a basic and seemingly unequivocal subject, we are met with subtle differences between the US and Europe. Case in point: How many continents are there? If you're from Europe, you may have answered six: Europe, Asia, Africa, Australia, Antarctica, and America. I, on the other hand, like most other Americans, was taught that there are seven continents, with America divided into South America and North America.

Now before we get entangled in a petty argument about elementary geography, it needs to be said that this is not a question with a clear right or wrong answer - like many, it's a subjective question, not an objective one, no matter how much the geography tests of our schooldays argue otherwise. And there are many more such questions - and answers - to come in this course. That's why, when learning about a different culture, you have to put your judgments aside, and be prepared to learn about a new, different way of looking at the world, one that is no better or worse, no more right or wrong, than 
yours - simply different. And this even goes for US culture, one that most of you are already quite familiar with through its widely distributed media.

Why is it important for you to learn about US culture? If you're planning on teaching English, you should understand that part of teaching a foreign language is teaching about the cultures it lives in. Though there is a wide variety of Anglophone countries and cultures, and I encourage you to delve into those which appeal to you, the fact is that the United States is the country home to the most native speakers of English, not to mention one of the world's most influential cultures, Anglophone or otherwise.

For future translators, an understanding of the source-language as well as the target-language culture is invaluable. The example of the number of continents is but one of countless discrepancies that a diligent translator of English should be aware of, regardless of the type of texts they translate. And the same naturally goes for prospective interpreters, who need to recognize cultural references and navigate subtle cultural differences on the fly.

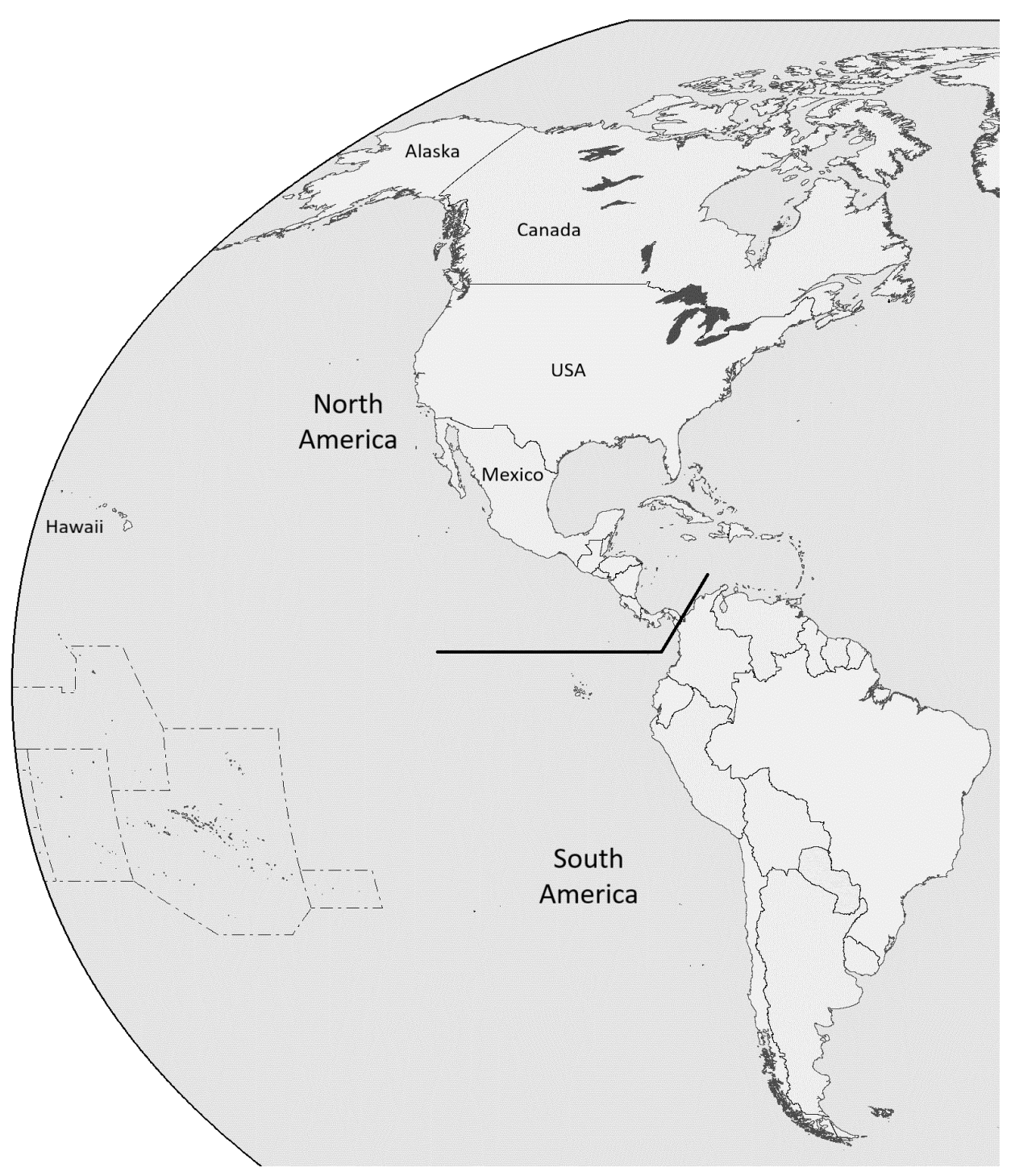

Figure 1: The Americas

\section{North America}

In Fig. 1, you can see that the North American continent is dominated by three large countries: Canada, the United States, and Mexico, bordered to the south by seven smaller countries that form the isthmus known as Central America, as well as the Caribbean islands. Thus the US in itself borders 
only two other countries: Canada to the north and Mexico to the south. This isolated position has had a major influence on the country's history and foreign policy, as you have already seen in your US history course.

\section{The USA's Three Parts}

Finally, note that the USA is made up of three separate areas:

* Alaska - a region to the west of Canada that comprises the USA's largest state.

* Hawaii - a long archipelago in the Pacific Ocean which is located approximately 4000 kilometers west of Mexico and is also a state in its own right.

The states between Canada and Mexico are technically known as "the contiguous United States", but often referred to colloquially as "the continental US" or "the lower 48 states". Why 48 ? Well, the country as a whole is made of up 50 states, and if we exclude the states of Alaska and Hawaii, $50-2=48$.

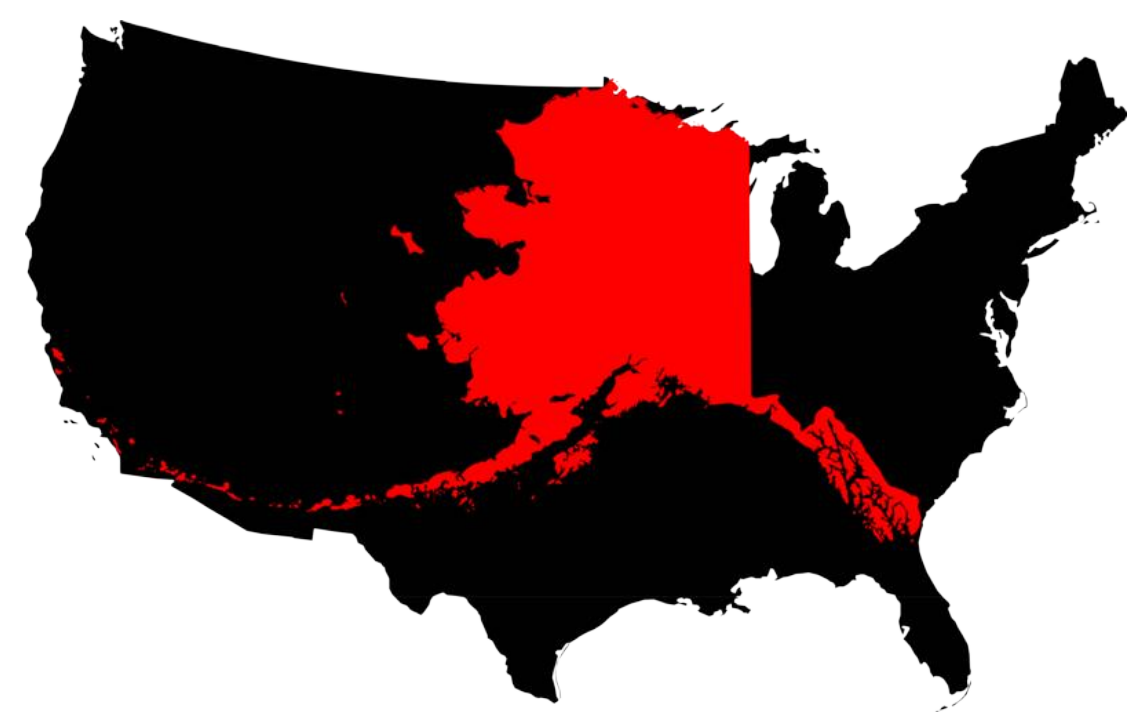

Figure 2: The relative sizes of Alaska and the Lower 48 States

With Alaska superimposed over the Lower 48, Fig. 2 shows how the largest state makes up a significant portion of the USA's total area, about $17 \%$ percent to be more precise. Its population, however, is roughly 730,000 - only about $0.2 \%$ of the country's 328 million people (see Fig. 4 ). 


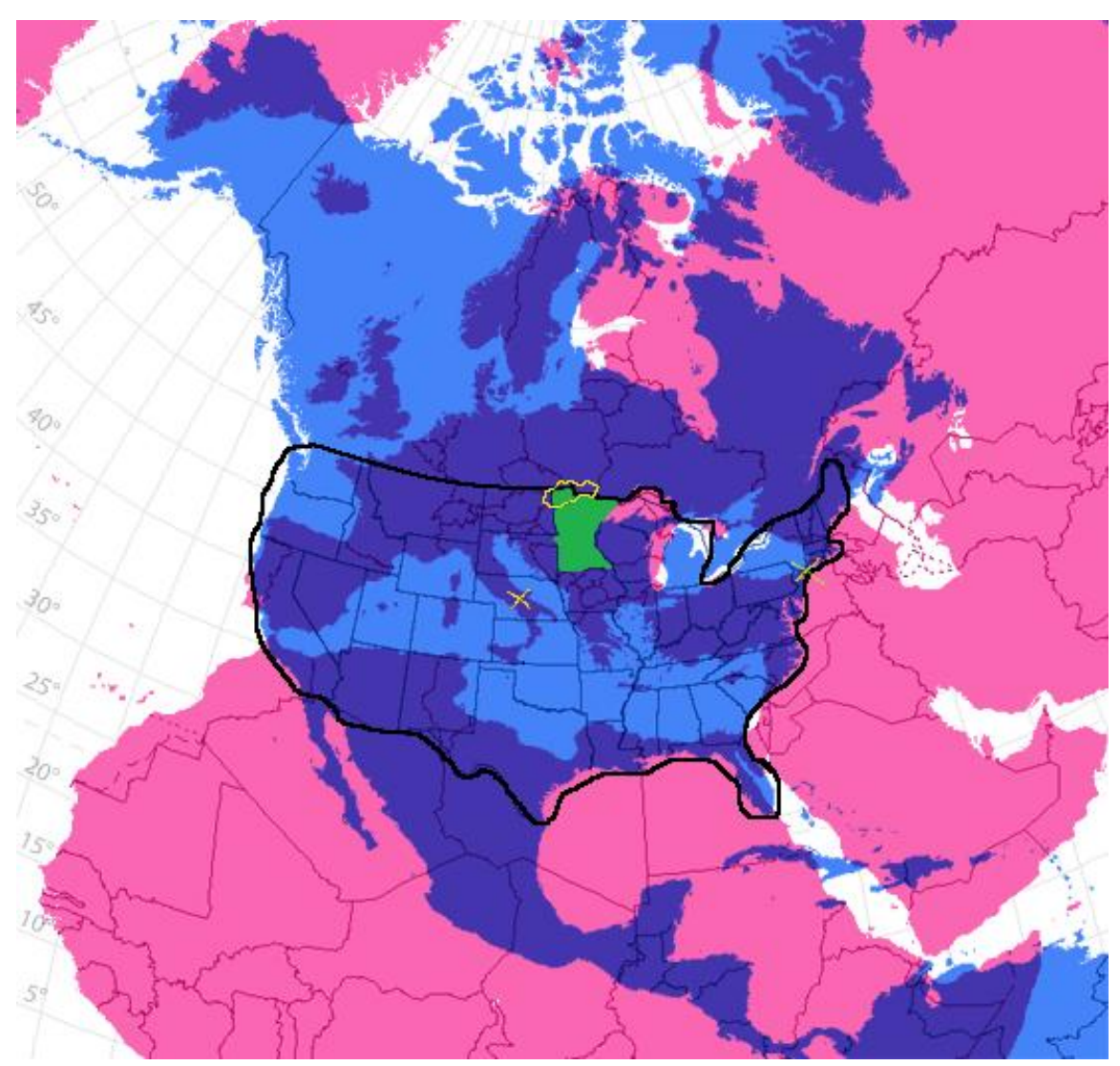

Figure 3: The relative size and latitude of the United States and Europe

\subsection{The US Compared to Europe}

\section{Geographic Size}

Fig. 3 superimposes North America over Europe, showing how the United States is about the same size as the European continent, defined as the European peninsula stretching westward from the Ural Mountains of Russia. In fact, even in exact area, they are strikingly similar: the United States covers $9,826,675 \mathrm{~km}^{2}$, while Europe encompasses 10,180,000 $\mathrm{km}^{2}$.

\section{Climate}

Now look at the map from a different perspective, keeping in mind that it maintains both continents' actual latitude. This highlights some surprising differences between their climates. It is common knowledge that Western Europe's climate is made milder by the Gulf Stream, but few realize that this effect extends to Central Europe as well, including Slovakia. To illustrate this, draw an imaginary line from Slovakia across the Atlantic Ocean to the US, and you'll see that it lines up with northern Minnesota, a state near the center of the USA's border with Canada. In Banská Bystrica, located at $48^{\circ} 43^{\prime} 57^{\prime \prime} \mathrm{N}$ and 362 meters above sea level, the average January low is $-6^{\circ} \mathrm{C}$. In International Falls, Minnesota, located at $48^{\circ} 36^{\prime} 6.01^{\prime \prime} \mathrm{N}$ and 342 meters above sea level, the average January low is a frigid $-21.4^{\circ} \mathrm{C}$, though its summers are similar to Banská Bystrica's, with a July average high of $25.4^{\circ} \mathrm{C}$ compared with BB's $26^{\circ} \mathrm{C}$.

A US city with winters more comparable to Banská Bystrica's is the university town of Bloomington, Indiana, located at $39^{\circ} 9^{\prime} 44^{\prime \prime} \mathrm{N}$ (marked in Fig. 3 by an X). Bloomington's summers, however, are much hotter than Banská Bystrica's: the average high in July is $30.7^{\circ} \mathrm{C}$, and combined with the high humidity, the effect is truly sweltering. 
This is a trend that can effectively describe the entire eastern half of the Lower 48: extreme seasonal differences, with snowy winters (except in the subtropical south) and hot, humid summers. Beginning with the Great Plains, which rise up to the Rocky Mountains, the western half of the Lower 48 is characterized by desert, mountain ranges, and a mild coastal climate caused by the Kuroshio Current, the Pacific Ocean's equivalent of the Gulf Stream.

\section{Climate Zones of the Contiguous United States}

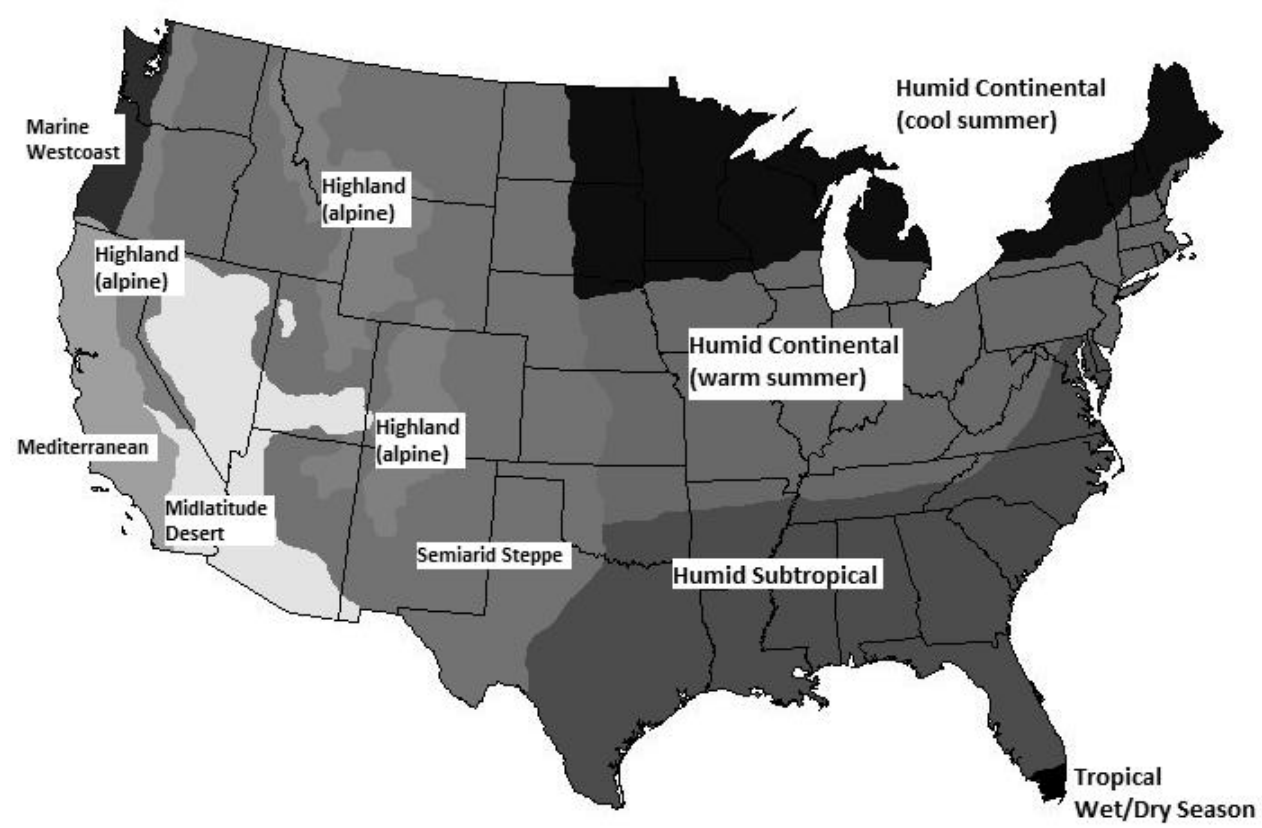

Figure 4

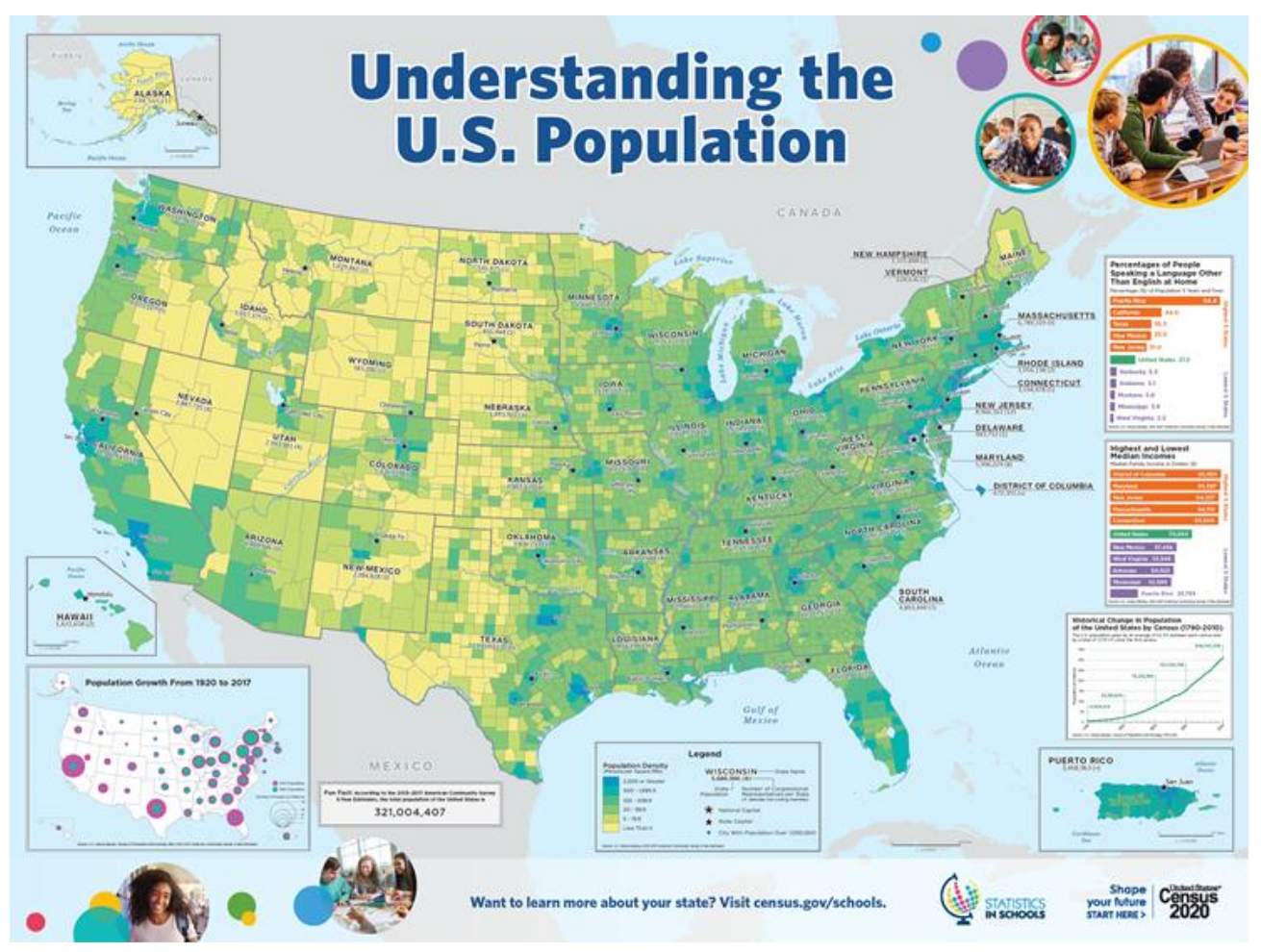

Figure 5: Population distribution 


\section{Population Density}

Though Europe and the USA are of similar geographic size, the USA is less than half Europe's size population-wise: 328 million people vs. 746 million. Given their similar area, it's clear that the US has a lower population density - less than half that of Europe.

Fig. 5 shows the distribution of the USA's population - the darker the color, the higher the population density. The black spots correspond to large cities, and you can see a clear distinction between the densely-populated east and the wide rural expanses to the west, with the exception of the West Coast. These sparsely-populated areas, along with Alaska, are the main reason for the country's low density compared with Europe.

\section{A Big-City Country?}

This brings us to a common European misconception of the USA: that it is a country of big, bustling cities. Such a perception is doubtlessly influenced by the number of Hollywood movies that take place in New York City or Los Angeles, the country's two largest cities. In fact, Europe has far more big cities than the United States. Europe is home to 39 cities with over one million inhabitants, while the US has only nine such cities.

Nonetheless, the big three - New York, Los Angeles and Chicago (all three circled in Fig. 6) - truly do warrant the title "metropolis", with eight million, four million, and three million people respectively.

\subsection{US Cities}

\section{Defining the US City}

This also raises the question: what is a city? This is another deceptively obvious question that is surprisingly difficult to answer. The fact is that Europeans and Americans differ greatly in their perceptions and expectations of their cities and the urban lifestyles of their inhabitants.

Clearly, the regions' differing histories play a major role. Many European cities trace their roots back to the Middle Ages or even antiquity, and these roots are often clearly visible in their historical centers. In fact, one could argue that a historical center, usually including one or more pedestrian zones, is among the criteria for a European city. That is not the case in the USA. There are cities with historical buildings, even districts, though these only date back to the 16th century at the earliest. The main difference, however, is that even among the oldest US cities such as Boston, New York City and Charleston, South Carolina, very few are concentrated in a clearly-defined historical center. 


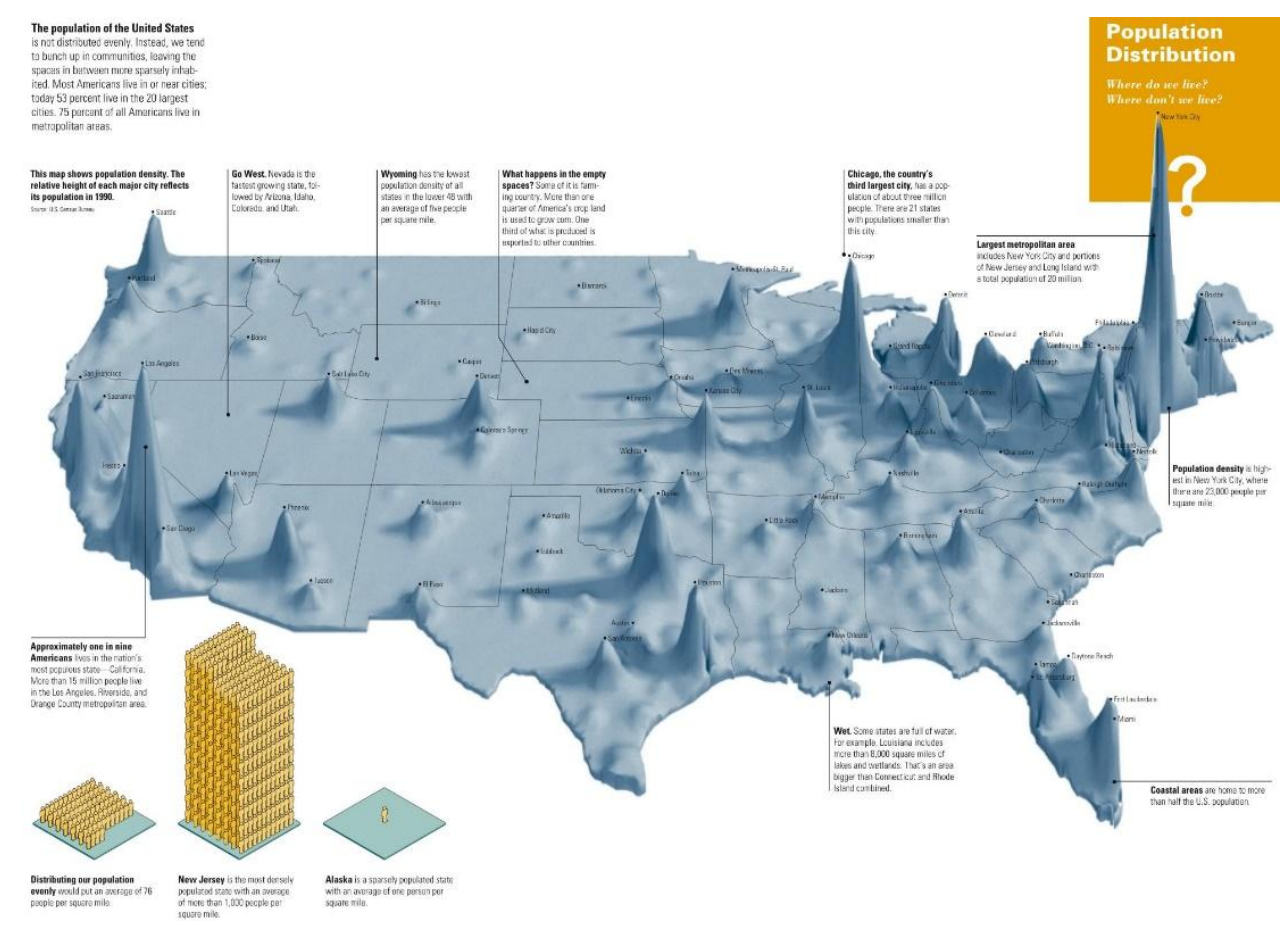

Figure 6: Major urban areas (from AGNEW-MOYER, 1999)

\section{Downtown}

The image most people have of a US downtown is a high-rise district dominated by towering skyscrapers, and this is a stereotype that does in fact mirror reality. Instead of being represented by a historical center or a main square, US cities are typically identified by their skyline: a panoramic silhouette of the city's tallest buildings. A product of both intentional planning and chance, a US city's skyline is something like its fingerprint.

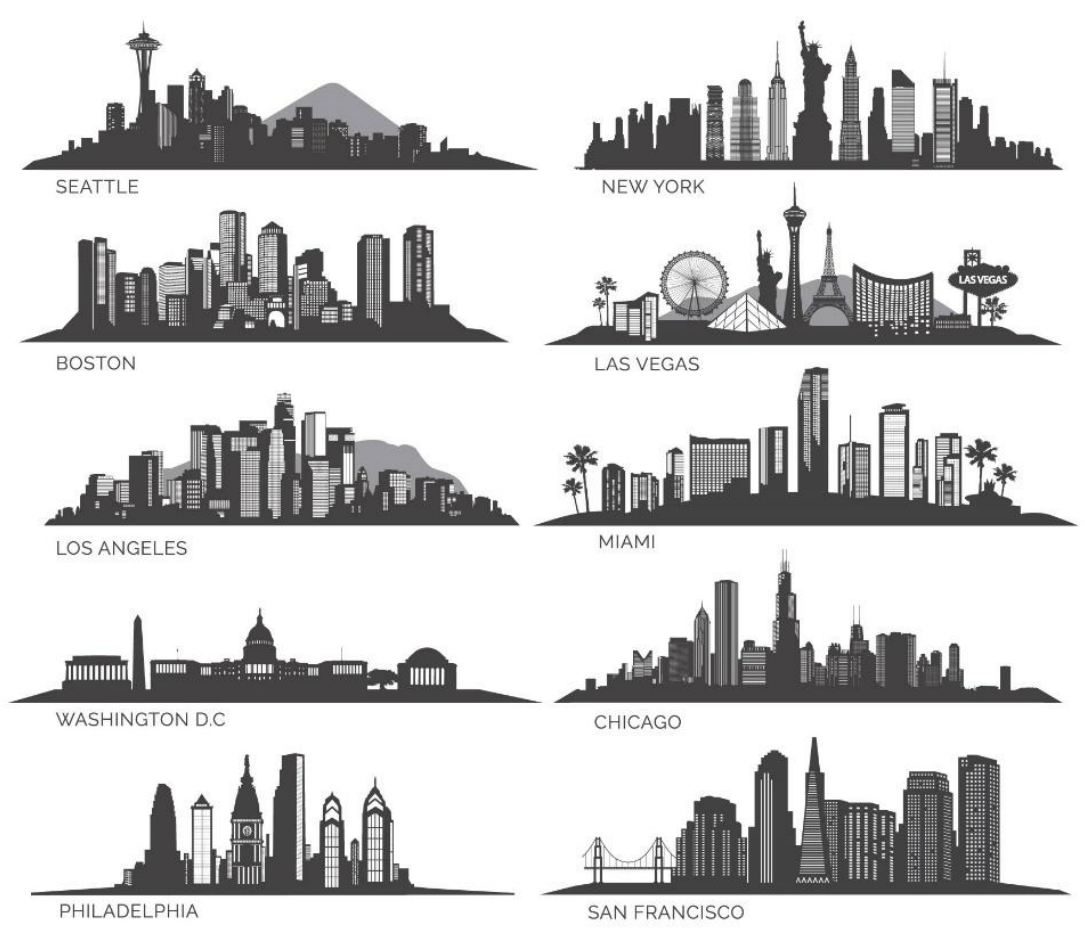


According to art historian Martin Kemp, "during the inter-war years, New York became linked to the notion of modernity. In the mid-1920s Georgia O'Keeffe produced images that emphasized the colossal grandeur of the city's skyline..." Her portrait of New York's Radiator Building projects an imposing verticality that has made its way into our imaginations. Through art and especially film, US cities have built up a reputation for being modern, quintessentially urban environments, which may explain Europeans' perception of the USA as more urban than Europe. On numerous occasions I've been faced with disbelief here when trying to explain that cities like Boston, San Francisco, Seattle and Denver are home to less than a million people. Perhaps part of this disbelief is rooted in the big impression their skylines make.

Click here to see Georgia O'Keeffe's painting “Radiator Building - Night, New York” (1927).

But what are these buildings, and how are these areas actually used? The areas they inhabit are generally referred to as financial districts, and the high-rises and skyscrapers are home to the headquarters of major corporations, especially financial institutions such as banks and insurance companies. In essence, these are places where white-collar professionals work. Not where they usually live, mind you, nor where they usually spend their leisure time. The result is a city center that can be quite bustling during the day, but is often shockingly empty in the evening.

One clear reason for building such tall structures is to conserve space. The modern American downtown was born in Chicago in the late 19th century in a construction boom that was galvanized by the city's (at the time) limited commercial space. But like nearly all architecture, including the most apparently utilitarian, these buildings also symbolize a range of ideas. Early skyscraper architect Louis Sullivan is probably best known for coining the modernist tenet "form follows function", but when reflecting on his own commanding creations he could be remarkably idealistic:

"The social significance of the tall building is in finality its most important phase. In and by itself, considered solus so to speak, the lofty steel frame makes a powerful appeal to the architectural imagination where there is any...The appeal and the inspiration lie, of course, in the element of loftiness, in the suggestion of slenderness and aspiration, the soaring quality as of a thing rising from the earth as a unitary utterance, Dionysian in beauty."

Or, as the employees of the Metropolitan Life Insurance Company sang in their company anthem:
We're the guardians of "The Tower,"
And the light which it enveils;
It's the symbol of our power
To its height no other scales.

The creators, denizens, admirers and critics of the USA's skyscrapers have held an enormous variety of opinions on what these edifices truly represent. On the other hand, at this point they have become more or less status quo, part and parcel of any self-respecting international metropolis. It is Europe that remains the glaring exception to this rule. Despite boasting 39 million-plus cities, Europe is oddly underrepresented among the world's 50 tallest cities, with only Moscow, Istanbul and Paris making the list at all. Yet again, it is looking at America that shows us what makes Europe such a unique place. The question I leave you with is: if skyscrapers are no longer anything special, and the lack thereof makes a more striking statement, then what is Europe saying by having so relatively few of them?

It hasn't always been this way, though, as you can see from an artist's recreation of medieval Bologna, Italy below. 


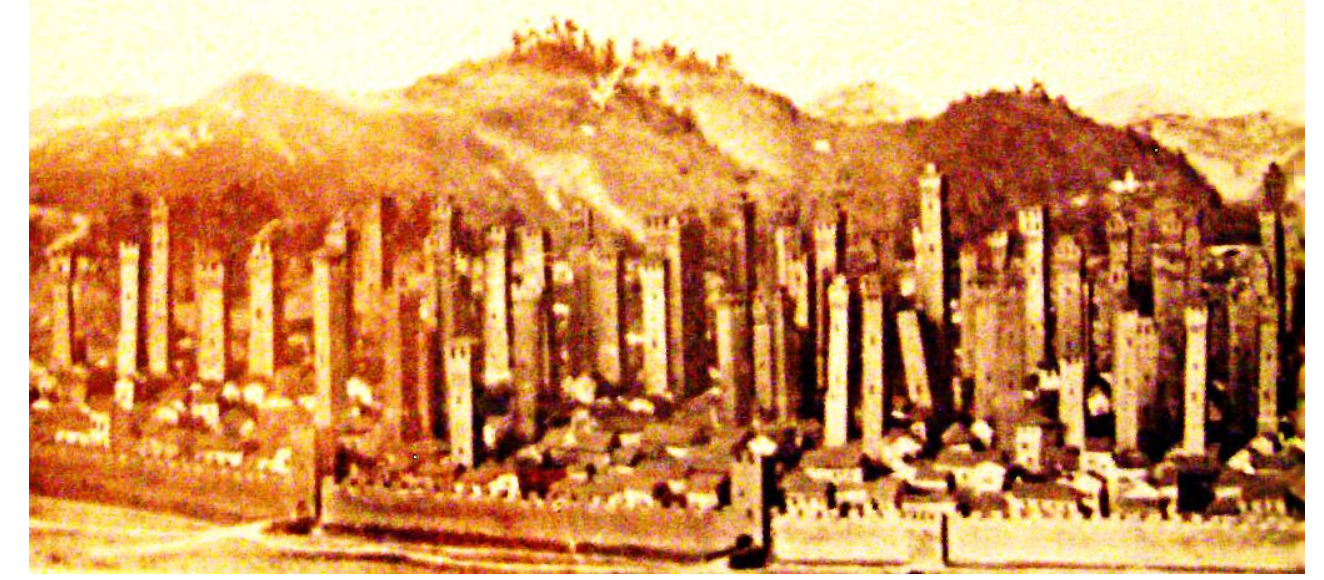

Figure 8: Angelo Finelli: "Model of Bologna at the Time of Dante" (Pianta topografica di Bologna nella seconda cerchia, 1917)

\section{Urban Sprawl}

While US cities are often visually associated with their upward growth, it is in fact their outward growth that has had the greatest effect on the lives of most Americans. Much of this spread has occurred in the form of suburbs.

Suburbs in some form have existed around cities for millennia, but since WWII they have taken on a more specific form in the US. Why was WWII such a pivotal event for urban development? Firstly, through the G.I. Bill, war veterans were given special benefits making it easier for them to take out loans and buy property. This led to a major real-estate boom that coincided with the post-WWII baby boom. Basically, soldiers came home, bought houses, started families - and bought cars.

At the same time, in the name of national safety, the government began constructing what would become the world's most extensive high-speed road network: the US Interstate Highway System. This meant that workers could live further from the cities where they worked. Before the highways existed, this commutable distance around US cities had been limited by the reach of their public transportation systems. By 1969, 83\% of American workers drove to work, and their commute averaged $15 \mathrm{~km}$. Fast-forward to 2010, and the average American worker's commute had reached 30 $\mathrm{km}, 91 \%$ of which were made by car.

The housing boom and the construction of the highway system combined to allow for a new type of suburb, bringing with it a car-oriented lifestyle that would come to define the newer, fast-growing metropolitan areas of the late 20th and early 21 st centuries. One well-known example of a post-WWII suburb is Levittown, New York (see Figure 9 below).

One of the most distinctive aspects of US urban planning is the clear separation of residential and commercial areas, a layout both favored by homebuyers and enforced by local zoning laws. The effect is that, especially in suburbs, residential areas are made up of street after street with nothing but houses, whose distance from one another grows with the wealth of the community. This is a place where privacy, so highly valued by Americans, comes first. This is a place for families, separate from the hustle and bustle of work and shopping. In fact, the closest shop of any kind can be quite a distance away. While in European countries like Slovakia, even village-dwellers are used to having a grocery store within walking distance, this is not the case for most Americans, even in urban areas.

Which brings us back to the car. The aforementioned statistics regarding commuting in the US indicate a broader phenomenon: Americans mostly move by car. This is partially due to the layout of our communities, but it is also influenced by our infrastructure: our extensive road system on the one hand, and our limited public transportation on the other. 


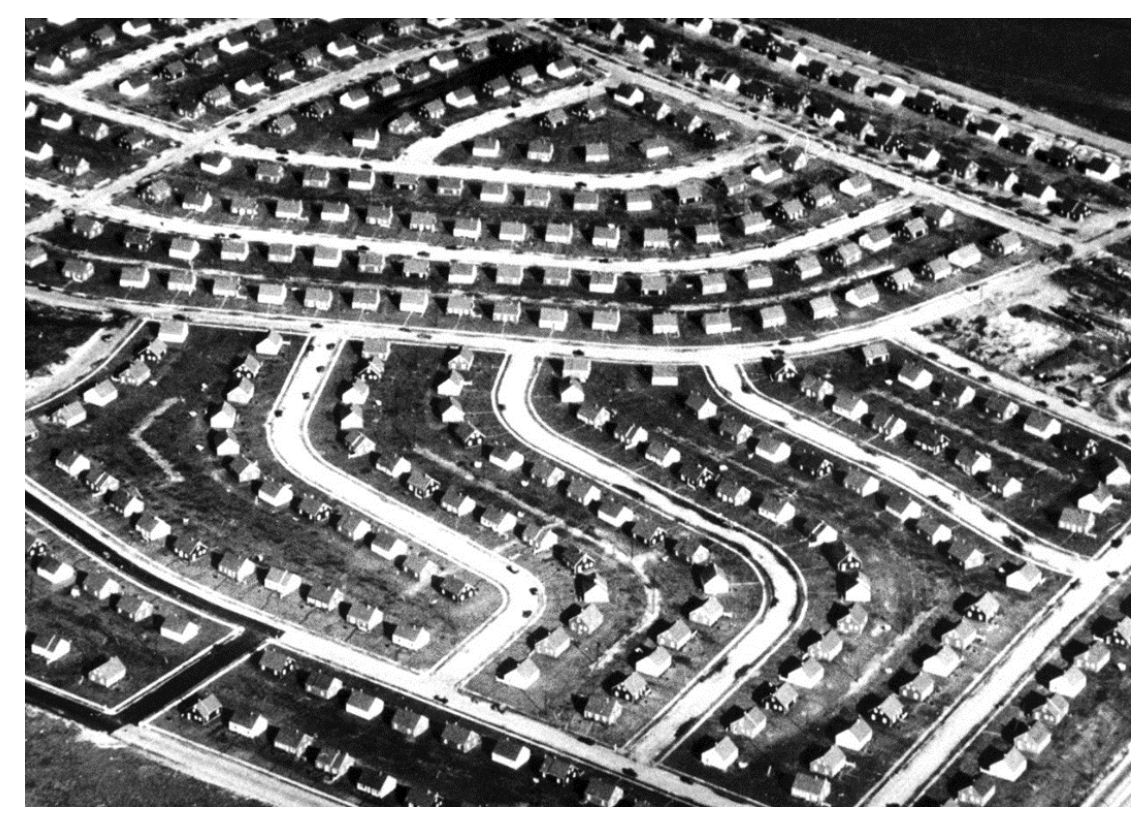

Figure 9: Levittown, New York in 1948

(AP Photo/Levittown Public Library, File)

\section{Public Transportation Use}

A 2008 study showed that only 5\% of Americans used public transportation "every day or most days", while $57 \%$ of them never used it. This is a major difference from all other countries studied. In Hungary, for example, the numbers are 37\% (every/most days) vs. 7\% (never) respectively, and other European countries display similar statistics.

Thus it is clear that public transportation plays a minimal role in the lives of most Americans. Nonetheless, looking at the statistics from 2012, an interesting trend is apparent: in nearly all European countries studied, public transportation use has decreased significantly since 2008. In the US, on the other hand, it has seen an increase of $6 \%$. Is this the beginning of a reverse trend, with Europeans driving more and more and Americans driving less and less? If it is, both "sides of the pond" still have a ways to go. 


\section{Follow-up}

1. How do the USA and Europe compare in terms of geographic size? What about in terms of population?

2. New York City is south of Rome, so why is it so much colder?

3. What parts of the US are the most densely populated?

4. How are US cities different from European cities? What are some of the historical reasons for this? Which type of urban planning makes more sense to you?

5. What examples of urban sprawl do you see in Europe? 


\section{Immigration to the USA - The Making of a "Nation of Immigrants"}

Americans are a nation born of an idea; not the place, but the idea, created the US government. (T. H. White)

In this chapter you will learn:

- What were some of the immigration patterns in the USA?

- What is paradoxical about the phrase "a nation of immigrants"?

- Who are some of the modern minorities in the USA?
Study and explain the following terms:
old immigration
new immigration
"birds of passage"
national-origin quotas
hemispheric quotas

\subsection{Immigration to the USA in Dates}

Patterns of immigration - Four Waves of Immigration

Immigration to the USA affected not only American history but even more so, American culture as well. From a historical perspective, scholars distinguish two types of immigration (pre- and postColumbian immigration) and four waves of immigration to the USA:

\section{Pre-Columbian immigration:}

- The pre-Columbian period (which, however, did not consist of a single wave, but many isolated events);

\section{Post-Columbian immigration:}

- The early colonists (who, however, did not yet comprise a wave);

- the First Wave of immigration (1680-1776);

- the Second Wave of immigration (1820-1890);

- the Third Wave of immigration (1890-1930);

- the Fourth Wave of immigration (1965-the present). 


\section{Pre-Columbian Immigration (40,000 years ago)}

The very first immigration of humans to the Americas likely started 40,000 years ago when people from Asia (Siberia) crossed the Bering Strait and came to present-day Alaska. Then they peopled North America and the entire western hemisphere. These people are called Indians or Native Americans (because they were the first to live in America, they are "native" there). It is estimated that approximately one to three million Indians lived in America when Columbus arrived in the New World. Generally, they represented well-developed cultures: some tribes built adobe houses, grew crops and produced artistic objects. Their lifestyles and values, however, were very different from those of the first colonizers. Compare:

\section{\begin{tabular}{l|l}
\hline The Indians: & The Puritans:
\end{tabular}}

\begin{tabular}{|l|l|l|l|}
\hline $\begin{array}{l}\text { were } \\
\text { polytheists: }\end{array}$ & $\begin{array}{l}\text { Worshipped many } \\
\text { gods and divinities. }\end{array}$ & $\begin{array}{l}\text { were } \\
\text { monotheists: }\end{array}$ & $\begin{array}{l}\text { Worshipped a } \\
\text { single god. }\end{array}$ \\
\hline $\begin{array}{l}\text { were } \\
\text { pantheists: }\end{array}$ & $\begin{array}{l}\text { Respected nature, } \\
\text { left it unharmed, } \\
\text { unchanged. }\end{array}$ & $\begin{array}{l}\text { believed in the } \\
\text { Bible/Scriptures } \\
\text { and Manifest } \\
\text { Destiny: }\end{array}$ & $\begin{array}{l}\text { Had a religious duty } \\
\text { cultivate the } \\
\text { wilderness in order } \\
\text { to transform it into a } \\
\text { "Garden of Eden" }\end{array}$ \\
$\begin{array}{l}\text { respected a are } \\
\text { egalitarian } \\
\text { hierarchy: }\end{array}$ & $\begin{array}{l}\text { Respected the } \\
\text { chief, the elders. }\end{array}$ & $\begin{array}{l}\text { more } \\
\text { social rigid } \\
\text { hierarchy: a }\end{array}$ & $\begin{array}{l}\text { Respected } \\
\text { hierarchical pyramid: } \\
\text { God, white men, } \\
\text { white women, } \\
\text { people of colour, } \\
\text { savages. }\end{array}$ \\
\hline
\end{tabular}

Different priorities resulted in great cultural misunderstanding and the gradual decimation of the Indian population: In 1860, there were only 340,000 Indians, and by 1910 , as few as 220,000 Indians in the USA. By the 1970 census, however, the Indian population had climbed to some 650,000. At present, 550 Indian tribes are recognized in the USA. These include: the Plains Indians (Arapaho, Blackfoot, Cheyenne, Comanche, Crow and Sioux), the Cherokee, the Navajo, the Apache and many others. Some of them live on reservations, land given by the government. 


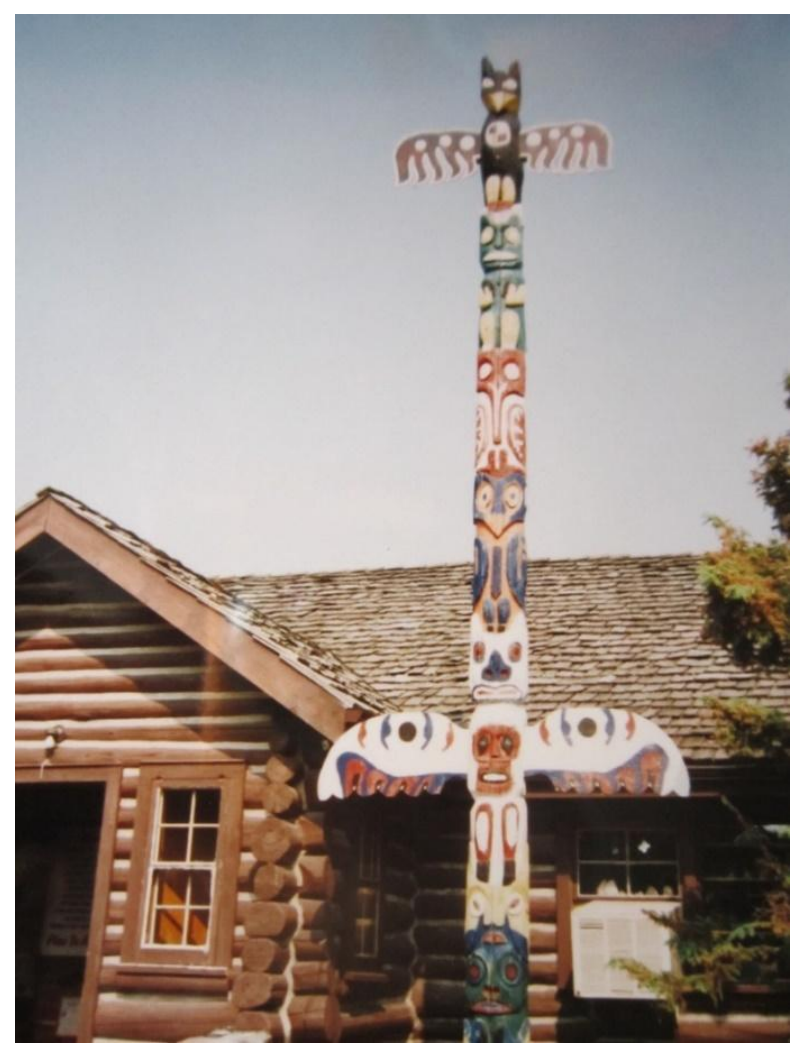

Figure 10: An Indian totem pole in front of a log cabin. For Native Americans in the Pacific Northwest, a totem pole was an equivalent of a present-day curriculum vitae: Indians could read their family history and important tribal events in them. Photo: Jana Javorčíková.

\section{The Early Colonists (1607-1680s)}

Between 1604 and 1607, the first European settlers came to the present-day United States; however, only the 1607 settlement (Jamestown, Virginia, named after King James I) managed to survive the winter and is, therefore, understood as the first permanent English settlement in America. In 1621 the Pilgrims came on a ship named "The Mayflower" and established a settlement. They set up the first political establishment resembling an early democracy known as the "Mayflower Compact." John Smith was one of their political leaders. A Puritan, Mary Rowlandson, was among the first to write about her captivity at the hands of Indians.

The early colonists, however, did not, strictly speaking, constitute a wave of immigration; their arrivals were random, scanty and far from the later "waves" of newcomers.

\section{The First Wave of Immigration (1680s-1776)}

What is sociologically considered the first influx of immigrants began in the 1680s after the European settlers' initial technical and political problems had been solved and some misconceptions about America had been clarified (e.g. lions were wrongly reported to be seen in Massachusetts).

These immigrants supplied the most desired commodity in the colonies: cheap labour force. Many Europeans (e.g. the Irish) were escaping harsh living conditions and famine back home. In order to pay for their journey to America, they often agreed to indentured servitude (SK: vazalstvo, nevol'níctvo) - a fixed number of years of work for the person who brought them over.

The Afro-Americans were another ethnicity who compensated for the lack of labour force. Unlike the Europeans (who were asked for their consent as indentured servants), the Afro-Americans were violently captured in Africa, and few of them survived the journey to America. The slave trade 
increased enormously after 1662. In 1671, one in 20 residents of Virginia was black; by 1770, four in 10 were.

The First Wave of immigration was put to an end with the War of Independence - in that period America was regarded as an unsafe country unfit to emigrate to.

\section{The Second Wave of Immigration (1820s-1890s)}

After the political scene calmed down following the War of Independence, another great influx of immigrants aimed at the American coasts. The development of industry and the opening of the territory to the West created new opportunities for masses of people. By 1850, the population numbered 23 million. Only 10 years later it totalled 31 million (Ibid.). These immigrants were mostly northern Europeans, specifically Scandinavians and Germans (the Germans were the largest 19thcentury immigrant group). Due to the colour of their skin, prevalent religion and origin as well as their lifestyle (the Germans, for example created communities with old-world institutions, such as music halls, beer gardens and athletic societies), they were called "the old immigration."

The Irish were another big 19th century group; unlike the Germans, they were the poorest community. Their lifestyle was very different from the WASPs, which created a lot of social tension.

\section{The Third Wave of Immigration (1890s-1930s)}

In the late $1820 \mathrm{~s}$, the incoming people started to differ in their ethnicity, origin and also reasons for coming. No more were they predominantly "white" - many of them came from Eastern and Southern Europe (Italy, Spain, Bulgaria and Romania) and visually were of darker complexion. They often viewed the USA as a land of opportunity and a place where one "gets rich quick" and wished to come for short periods only to earn money and then return back home. Therefore, they were called the "birds of passage" or "new immigration" to distinguish them from the previous generations of immigrants. The relations between the "old" and "new" immigration were quite antagonistic; "new immigrants" were often looked down upon or downright discriminated against.

During the Third Wave of immigration, there were the first attempts to regulate and organize immigration to America:

- In 1870, "night schools" for immigrants were established where they could learn basic English. However, immigrants were mostly taught nothing but instructions they needed at work (e.g. simple words such as Start!, Finish!, End of break!); oftentimes they could not communicate about general topics at all.

- In 1892, the "Pledge of Allegiance" (SK: Prisaha vernosti vlajke) to the flag was established to strengthen newcomers' relationship towards the USA.

- In the 1930s, the most severe regulations of immigration occurred; immigrants from certain regions (e.g. China) were banned from coming or subjected to national-origin quotas numbers of admissions per country (SK: národné pristahovalecké kvóty).

The Civil War and the abolition of slavery also changed the social hierarchy in the USA; the largest minority group in the nation's history (Afro-Americans) was created. However, the abolition of slavery led to many paradoxes: former slaves were liberated and theoretically could compete with other minorities for jobs; however, they were unskilled and untrained, and thus they had to orientate towards low-paid types of work.

\section{The Fourth Wave of Immigration}




\section{(after the Second World War; 1965 to the present)}

After the Second World War, hemispheric as well as regional quotas were established; these regulated the number of immigrants per country or per hemisphere (SK: kvóty pre južnú/severnú pologulu). However, hemispheric and regional quotas were later taken as discriminatory. Today, each request for a US visa or citizenship is evaluated individually, according to the individual needs of the requester. As a result, several categories of immigrants are recognized and referred to formally or informally in the media, e.g.:

immigrant/emigrant: refers to a person who comes to a country to live there permanently.

migrant: a person who only stays in the target country for a limited period of time or trespasses into the country.

refugee: a person who seeks asylum in the target country, usually due to a military conflict or unrest in their home country.

DP: a "displaced person", somebody who physically lost their home or native land due to war, famine, natural disaster, etc.

boat people: these are mostly illegal Cuban immigrants heading for Miami, Florida. They are called "boat people" because in order to escape Fidel Castro's regime, they often use unsafe boats, rafts and makeshift floating devices.

The skills and education of the asylum or visa seeker also play an important role in the process of acquiring American citizenship or a green card (a card permitting one to work legally in the USA). The USA successfully recruits skilled professionals from around the world, which logically reduces the skilled workforce in their home countries; this phenomenon is called "brain drain". Before starting a job, each applicant has to fill in an official form called an I-9 form that confirms the applicant's right to work in the USA.

The common phrase "nation of immigrants" (based on the title of a 1958 book by US president John F. Kennedy) thus refers to a popular paradox: immigrants (meaning newcomers from all corners of the world) historically could not form a nation (usually defined as a community of people sharing a common history, language and living in a particular territory under one government); yet, after many historical events, social changes, civil rights movements and perpetual struggle for equality for all, they have formed a modern, historically unprecedented type of nation - the Americans.

\subsection{Social Theories and Metaphors}

Immigration has been analysed by many professional sociologists. Immigration to the USA has been explained with the use of several social theories and metaphors, which explain and illustrate the attitude of mainstream society toward immigrants (marginal groups) in various periods of US history. The most famous ones describe various ways in which cultures merge (such as integration and acculturation) and include:

- $\quad$ the Melting Pot metaphor;

- the Pizza metaphor, the Salad Bowl metaphor, the Vegetable Soup metaphor, the Orchestra, Mosaic metaphors;

- $\quad$ the Hybrid metaphor (see the next table).

\begin{tabular}{|l|l|l|l|}
\hline Decade & Soc. theory & Soc. metaphor & Example \\
\hline
\end{tabular}




\begin{tabular}{|l|l|l|l|}
\hline $1920 \mathrm{~s}$ & $\begin{array}{l}\text { Americanisation } \\
\text { assimilation }\end{array}$ & $\begin{array}{l}\text { the Melting Pot } \\
(1908, \text { I. Zangwill })\end{array}$ & the Slovaks \\
\hline $1960-80$ & $\begin{array}{l}\text { acculturation } \\
\text { (reciprocal } \\
\text { cult. borrowings) }\end{array}$ & $\begin{array}{l}\text { Salad Bowl } \\
\text { Pizza, Vegetable Soup } \\
\text { Mosaic } \\
\text { Orchestra }\end{array}$ & the Japanese \\
\hline $1980-90$ & $\begin{array}{l}\text { cultural pluralism } \\
\text { multiculturalism }\end{array}$ & the Hybrid, grafting & African Americans \\
\hline
\end{tabular}

Social theories known as "Americanization", "assimilation", "acculturation", "multiculturalism" and "cultural pluralism" refer to the relationship between the mainstream (e.g. the dominant group in the society, such as the WASPs) and marginal groups (e.g. Ukrainian immigrants).

Americanization and assimilation were theories popular at the beginning of the 20th century. Those who believed in the Americanization of immigrants assumed that newcomers were eager and willing to shed their national or religious traits (visible - dress code, turbans, burqas, religious symbols; and invisible - way of life, arranged marriages, family hierarchy, omerta) in order to fully integrate into mainstream American society. In 1908, journalist Israel Zangwill wrapped the phenomenon of Americanization/assimilation into the famous metaphor called the "Melting Pot." In this, he compared the Americans to various ingredients (such as vegetables, meat and spices) that differ in taste, texture and colour; however, once they end up in the melting pot (meaning the USA), they "melt" into a single body and lose their differences. Generally, the Slovaks permanently living in the USA could serve as an example of Americanization and assimilation; visually, they do not differ from what many believe a "typical" American looks like and they usually do not maintain any dramatically distinctive personal or religious features that would differ them from the Americans. Oftentimes, they adopt many American habits; for example, they celebrate Independence Day and Thanksgiving, they adopt the American cuisine and dress code. On the other hand, the Melting Pot theory has been criticized on the grounds of marginalizing, dispossessing, displacing and forgetting some cultures.

Americanization and assimilation were criticized by professional sociologists in the liberal 1960s. Unlike the Slovaks, there are many nationalities in the USA who represent so-called "visible minorities." That means their nationality and religion are visible (e.g. their skin colour, shape of their eyes, nose or lips or clothes - wearing turbans, saris, burqas, etc.).

For visible minorities, it is often culturally or religiously unacceptable to melt into another culture. Thus sociologists in the 1960s suggested another social theory, acculturation, which seemed less restrictive than the Melting Pot. Acculturation believes in tolerant co-existence and reciprocal cultural borrowings among cultures. These concepts can be described using three different metaphors: "Pizza", "Vegetable Soup" and "Salad Bowl". In all of these, the original ingredients (meaning the newcomers and their individual and cultural traits) are still visible, and they enrich the final dish (society); however, they do not melt (shed their differences). The Japanese minority in the USA serves as an example; they have adopted the American way of life but also preserved many of their Japanese cultural traits (e.g. family hierarchy). On top of that, they have also enriched American society by introducing and popularizing Japanese cuisine across the USA. On the other hand, the Japanese identified with American society and values so well that they proudly fought for the USA in 
the Second World War, even though at the same time thousands of Japanese Americans were forcibly relocated to US internment camps.

The postmodern tendencies of the 1990s advocated an even more liberal attitude towards the coexistence of cultures called multiculturalism. Multiculturalism is the support of cultural diversity and belief in the peaceful and tolerant co-existence of cultures. One of the social metaphors related to multiculturalism is called the "Hybrid". The hybrid metaphor involves fusion, the creation of a new form which can be set against the old form of which it is partly made up. A hybrid society is an organic system, and a new culture grows into the already existing system through "grafting". As a result, both cultures become interconnected, and though differences are visible, they are inseparable and benefit from each other. The African American minority in the USA has integrated into the mainstream this way: they have enriched the language and the way of life in such an immense way that it is difficult to treat them as a minority.

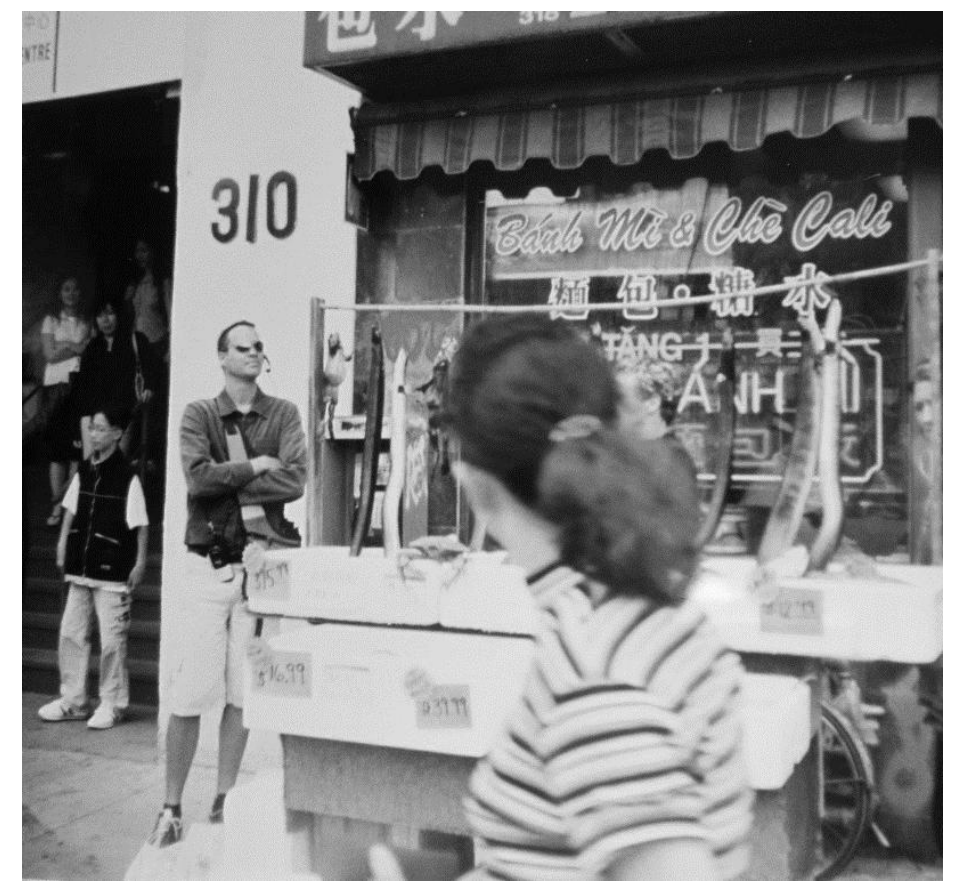

Figure 11: Cultural borrowings: mainstream Americans shopping for exotic food and ingredients at a Vietnamese street market. Photo: Jana Javorčíková.

A variant of multiculturalism called cultural pluralism advocates extreme tolerance and even accepts extreme demonstrations of individual cultures such as arranged marriages (SK: dohodnuté sobáše), female circumcision (SK: ženská obriezka) and omerta (SK: krvná pomsta). However, such tolerance might lead to serious legal problems.

\subsection{Lexical and Cultural Borrowings}

As a result of extended immigration to the USA, many cultural and lexical borrowings have occurred. The term "lexical borrowing" denotes a new word adopted from the lexicon of a foreign language, for example fondue (French), dim sum (Cantonese Chinese) and robot (Czech). A "cultural borrowing" denotes the adoption of an entire cultural phenomenon, technique, habit or tradition. For example, the German tradition of decorating a coniferous tree on Christmas Day has been adopted in many households in America. Thus the Americans learned from immigrants not only new words but also entirely new habits and procedures denominated by them (see the following table): 


\begin{tabular}{|c|c|c|c|c|}
\hline NATIONALITY & $\begin{array}{c}\text { TECHNOLOGIES } \\
\text { INVENTIONS }\end{array}$ & $\begin{array}{l}\text { HOLIDAYS } \\
\text { CUSTOMS }\end{array}$ & $\begin{array}{c}\text { SOCIAL } \\
\text { INSTITUTIONS }\end{array}$ & CUISINE \\
\hline the French & $\begin{array}{l}\text { dancing } \\
\text { portage }\end{array}$ & & bureau & chowder \\
\hline the Germans & lumber industry & $\begin{array}{c}\text { Christmas } \\
\text { tree }\end{array}$ & kindergarten & $\begin{array}{l}\text { hamburger } \\
\text { frankfurter } \\
\text { sausage } \\
\text { sauerkraut }\end{array}$ \\
\hline the Italians & wine processing & & mafia & $\begin{array}{c}\text { pasta } \\
\text { pizza, lasagna } \\
\text { minestrone }\end{array}$ \\
\hline the Japanese & $\begin{array}{c}\text { karate } \\
\text { ikebana }\end{array}$ & & & $\begin{array}{c}\text { sushi } \\
\text { teriyaki }\end{array}$ \\
\hline the Dutch & tulip cultivation & $\begin{array}{l}\text { Santa Claus } \\
\text { ice-skating }\end{array}$ & boss & $\begin{array}{l}\text { cookie } \\
\text { doughnut } \\
\text { coleslaw }\end{array}$ \\
\hline
\end{tabular}

The word to portage is an example of both lexical and cultural borrowing, as the Americans adopted early transport technologies from the French.

to portage $=$ to carry boats or goods overland between two

rivers, lakes, especially on a canoeing trip.

At the same time as adopting the technology, however, they adopted the French word for it and thus it entered the lexicon of American English.

There are many words in American English that have an interesting history. Some of these are:

\section{hamburger}

At the end of the 19th century, many immigrants left for the USA. They set off from various European ports and Hamburg, Germany was one of the most popular ones. To provide themselves with a longlasting and practically packaged food, the immigrants developed a habit of placing a piece of meat inside a halved bun. This meal was named, accordingly, a "hamburger". Further linguistic history of the word is even more interesting. As the meal grew popular, there was a demand for a greater variety of flavours and fillings. Thus, the final part of the word, burger, was taken as a meaningful word (despite that no such word existed in English) and new nouns were added to it to form a new compound, e.g.:

$$
\begin{gathered}
\text { cheese-burger } \\
\text { fish-burger }
\end{gathered}
$$

According to the word-formation of hamburger, the word frankfurter was later coined. 
Unlike hamburger, teenager is a word that the Americans coined and exported overseas. Until the 1950s, young people were not important (in the financial sense of the word) in American society and thus there was no word for them. They were called and treated as children until they became adults. However, in the 1950s the American economy was on the upswing. Young adults started to work parttime, and they could keep their pocket money and spend it at drive-in cinemas, fast food restaurants and music shops. For the first time in the country's history, they became a demographic with purchasing power and thus needed a name to be identified with within the economic system. The suffix -teen was combined with the noun age and the nominalising suffix -er, and the word teenager was coined.

\subsubsection{American English}

So many different people speak English in the world that there are many different "Englishes", e.g. Australian English, Canadian English and the Cockney dialect of English:

- Standard British English (also called “the Queen's English") is the language of educated English speakers; it is most often spoken by members of the Government, the BBC and the prestigious universities.

- American English is the variant of English used in the USA. It is sometimes referred to as General American English (GA). This is the form of English used most often in American TV programmes on national television.

Professional scholars, however, have not yet decided whether American English (AmE) is an entirely new language or just a regional variety of standard British English $(\mathrm{BrE})$. As scholars have it, "written English is more or less the same in both Britain and the USA and in everyday speech the two peoples have little difficulty in understanding one another". However, AmE differs from BrE in several areas:

- the phonetic level: pronunciation; intonation

- the orthographic level: spelling

- the lexical level: vocabulary

- the grammatical level

Reasons for differences between BrE and AmE: On the east coast of America, the speech of the first settlers reflected the changing speech patterns of British English, given that commerce, travel and education were in close contact. Slowly, this contact was interrupted or broken due to political changes, lost commercial ties between the two countries, but also due to new influences on AmE. Here are some of them:

a) the emergence of a new (and urgent) linguistic need to name previously unknown phenomena such as topographic and climatic phenomena, flora and fauna; the settlers either invented a word (e.g. jimson weed) or borrowed an Indian word (e.g. raccoon, skunk, pecan, hickory, wigwam, teepee).

b) contact with other nationalities, religions and languages intensified; many lexical borrowings were made from other languages, e.g.:

Dutch: Yankee (Jan Kees is a Dutch local fool; SK: Hlúpy Jano)

French: bayou (SK: pomalá voda, mŕtve rameno), caribou (SK: severoamerický sob), prairie, calumet 
Spanish: mesa, arroyo, ranch, lasso, sombrero, rodeo

West African languages: boogie-woogie, banjo, voodoo, jazz

c) The southern and northern varieties of $\mathbf{A m E}$ started to diverge as well. The North maintained a closer relationship with England; in the South, the contact with England was more scanty and random and that inevitably influenced the language used in these parts of America. Interestingly, the reasons for preserving the relationship with England were rooted in the geography of the region.

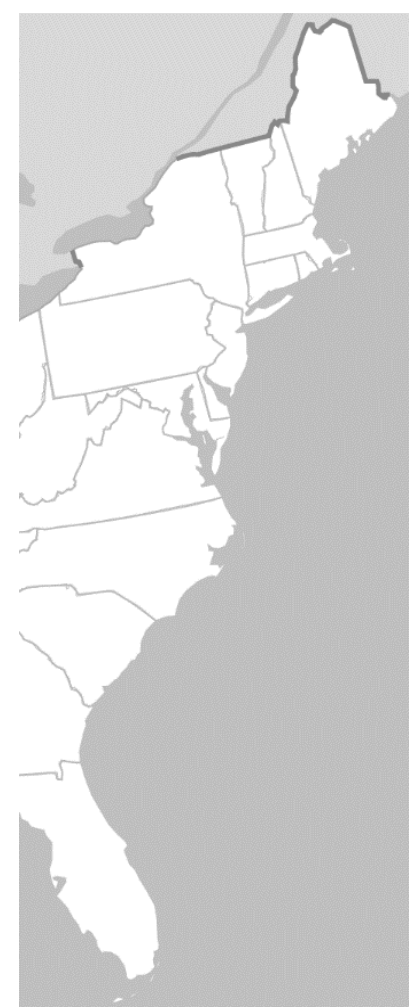

Figure 12: The rugged northern coastline, the even southern coastline

As we can see in the map, in the north, the coastline is rugged (SK: členitá, rozoklaná) and uneven, which gives the opportunity to build safe harbours. These harbours enabled the import and export of goods, materials, and people, as well as mail, and thus in the north there was a closer relationship with England, and BrE was preserved.

The coastline in the south is more even, exposed to the high tide. As a result, harbours were scanty, and that inevitably restricted contact with England. Therefore, Southern American English differs from standard British English much more.

Lexical and semantic differences between $\mathrm{AmE}$ and $\mathrm{BrE}$ : Differences between $\mathrm{AmE}$ and $\mathrm{BrE}$ are multiple. They include:

- the phonetic level: pronunciation; intonation

- orthography: spelling

- the lexical level: vocabulary

- the grammatical level

Phonetic level: pronunciation; intonation: 
AmE pronunciation differs from the BrE in similar fashion as Slovak and Czech. When native English speakers hear somebody speaking English spontaneously, they are immediately able to identify whether the person is English or American. Some Americans, for example, have a tendency to skip the $/ \mathrm{t} /$ sound after an $/ \mathrm{n} /$ in some words, for example: internet, international.

\section{Orthography: differences in spelling:}

The following table shows the most striking differences between the BrE and AmE spelling:

\begin{tabular}{|c|c|}
\hline Standard British English & American English \\
\hline centre & center \\
\hline metre & meter \\
\hline colour & color \\
\hline neighbour & neighbor \\
\hline travelling & traveling \\
\hline
\end{tabular}

\section{Lexical level: differences in vocabulary:}

Some word pairs are simply different words for the same concept; some also reflect a slightly different "reality." Linguistically different word pairs are, for example:

\begin{tabular}{|c|c|c|c|}
\hline Lexical Field & British English & American English & Slovak \\
\hline \multirow[t]{4}{*}{ Buildings: } & flat & apartment & byt \\
\hline & bed-sitter & one-room apartment & garsónka \\
\hline & surgery & doctor's office & ordinácia \\
\hline & ground floor & first floor & prízemie \\
\hline \multirow{6}{*}{$\begin{array}{l}\text { Transport } \\
\text { (BrE)/ } \\
\text { Transportation } \\
\text { (AmE) }\end{array}$} & crossroads & intersection & križovatka \\
\hline & flyover & overpass & nadjazd \\
\hline & zebra crossing & crosswalk & priechod \\
\hline & pavement & sidewalk & chodnik \\
\hline & motorway & highway, expressway & d'ial'nica \\
\hline & railway & railroad & železnica \\
\hline \multirow{2}{*}{$\begin{array}{l}\text { Means of } \\
\text { transport/ } \\
\text { transportation: }\end{array}$} & lift & elevator & výt'ah \\
\hline & tram & streetcar & električka \\
\hline
\end{tabular}




\begin{tabular}{|l|l|l|l|}
\hline \hline & lorry & truck & $\begin{array}{l}\text { nákladné } \\
\text { auto }\end{array}$ \\
\hline
\end{tabular}

However, there are also many culturally motivated words in which the semantic difference lies in different "realia." For example, the American drugstore sells a wider variety of products and services than a traditional Slovak drogéria; one may also purchase a variety of medications and pills, have photographs printed or, more recently, even get a vaccination shot.

Grammatical level: Popular stereotype has it that in AmE, there is a general tendency toward simplification of the English language. That includes, for example, the tendency toward monosyllabism (active use and preference of short, phrasal words to Latin and Greek root words). However, such a statement would require lengthy research which has not been conducted yet. A grammatical difference that is seen as more common in AmE is the position of the word "also" at the end of a sentence. Another difference is the position of the word River. In AmE it usually comes after the river's name (the Colorado River), while in BrE it precedes it (the River Thames).

\subsubsection{Borrowings from other cultures and languages}

Lexical and cultural borrowings from various cultures and languages, including Indian languages, represent a special chapter in the development of AmE. When the first colonizers and settlers entered America, there were an immense number of phenomena (flora, fauna, Indian objects and constructions) that urgently needed a name. The first settlers solved the problem by one of the following:

1. They adopted an Indian word (and preserved or altered its pronunciation due to phonetic reasons). Such originally Indian words that entered the AmE lexicon are:

Animals: raccoon (small furry animal; SK: mýval), woodchuck (a marmot; SK: svišt'), chipmunk (squirrel; SK: deňka), opossum (SK: vačica)

Plants: hickory, pecan, catalpa, tapioca

Constructions: wigwam, teepee

Cultural institutions: powwow (an Indian meeting; SK: rokovanie), podunk (village)

Means of transport: canoe, toboggan (sledge used on snow);

Clothes, shoes: anorak, moccasin

2. Adopted an Indian concept, but they translated it to English e.g.:

to bury the hatchet $=$ to stop fighting

war paint = face paint worn during a battle or competition

fire-water $=$ spirits, whiskey 
3. Adopted or borrowed a word from another language, e.g. French. The word portage is an example of such an occurrence.

4. Translated a word from another language to AmE. For example, German ausfüllen became to fill out instead of the British to fill in, though some Britons now use fill out.

5. Invented a word (a neologism). This occurred rarely, however; the name of the state Idaho is an example of a made-up word that is supposed to resemble an Indian word. Another word invented for a local plant is jimson weed.

On the other hand, the Americans not only borrowed words and cultural phenomena from other languages but also exported many words and phrases to other languages. This "cultural lease" occurred mostly during both world wars and also after them via films, tourism and globalization. The following words, nowadays widely used worldwide, are of purely American origin: teenager, boyfriend, downtown, radio, commuter, fan (in football), right away (at once), let's face it (let's admit), be in the red (in debt to your bank) and way of life. Also, the phrase Have you got a pen? sounds more British than its American counterpart, Do you have a pen?

Black English (also called African American Vernacular English, or AAVE) is a special variant of American English, rooted in the slavery days. It is spoken by some African Americans (most often when they talk to other African Americans) and in the days prior to the Civil Rights Movement it was considered incorrect. Nowadays it is treated with more respect. Some AAVE expressions are:

\begin{tabular}{|l|l|}
\hline Standard American English: & AAVE: \\
\hline good, excellent & hot, cool \\
\hline bad & cool \\
\hline I don't have any money. & $\begin{array}{l}\text { I ain't got no money (several } \\
\text { negatives) }\end{array}$ \\
\hline help (pronounced: help) & $\begin{array}{l}\text { pronounced: /heop/ (dropping } \\
\text { the /L/ sound) }\end{array}$ \\
\hline self (pronounced: self) & pronounced: /scof/ \\
\hline
\end{tabular}

In the past, AAVE for many mainstream Americans indicated a lack of education; nowadays it is tolerated at some schools as it helps the African American students understand and communicate better.

New trends in American English: English all around the world has been influenced by another recent political trend called "political correctness" (also abbreviated as "PC"). It is a trend of avoiding certain attitudes, actions and forms of expression that might sound offensive, chauvinist, or discriminatory or relate to only one of sexes. The idea of PC developed in the 1980s and 1990s; however, it is rooted in the thoughts of the 1960s civil rights movement that protested against sexual and racial harassment. PC language also avoids stereotyping (having fixed ideas about people or groups of people). Politically correct alternatives to certain expressions include: 


\begin{tabular}{|l|l|}
\hline Politically incorrect: & Politically correct: \\
\hline $\begin{array}{l}\text { Miss (single), Mrs. (married), } \\
\text { (indicate marital status) }\end{array}$ & Ms. (pronounced /mIz/) \\
\hline waiter/waitress & server \\
\hline steward/stewardess & flight attendant \\
\hline fireman & firefighter \\
\hline mailman & mail carrier \\
\hline anchorman & anchor(person) \\
\hline chairman & chair(person) \\
\hline
\end{tabular}

Other groups of words that tend to be modified in order to avoid possibly negative connotations are:

\begin{tabular}{|c|c|c|}
\hline $\begin{array}{l}\text { Semantic field } \\
\text { (topics, issues): }\end{array}$ & Politically incorrect: & Politically correct: \\
\hline \multirow[t]{3}{*}{$\begin{array}{l}\text { Words for } \\
\text { ethnicities: }\end{array}$} & $\begin{array}{l}\text { - black (in certain } \\
\text { contexts) }\end{array}$ & $\begin{array}{ll}\text { - } & \text { Afro-American } \\
\text { - } & \text { Black (in certain } \\
\text { contexts) }\end{array}$ \\
\hline & $\begin{array}{l}\text { - Indian (in certain } \\
\text { contexts) }\end{array}$ & - Native American \\
\hline & - coloured (people) & - person of colour \\
\hline \multirow[t]{3}{*}{$\begin{array}{l}\text { Words referring } \\
\text { to someone's } \\
\text { disabilities or } \\
\text { medical } \\
\text { conditions: }\end{array}$} & - crippled & $\begin{array}{ll}\text { - } & \text { disabled } \\
\text { - } & \text { differently abled }\end{array}$ \\
\hline & - blind & $\begin{array}{l}\text { - visually impaired } \\
\text { (SK: zrakovo } \\
\text { znevýhodneni) }\end{array}$ \\
\hline & - deaf & - hearing impaired \\
\hline
\end{tabular}




\begin{tabular}{|l|l|l|}
\hline $\begin{array}{l}\text { Words referring } \\
\text { to one's age: }\end{array}$ & - old & - senior citizen \\
\hline $\begin{array}{l}\text { Words referring } \\
\text { to one's financial } \\
\text { situation: }\end{array}$ & $-\begin{array}{l}\text { housing for the } \\
\text { poor }\end{array}$ & $\begin{array}{l}\text { low-income } \\
\text { housing (SK: } \\
\text { nizkoprahové byty) }\end{array}$ \\
\hline
\end{tabular}

Interestingly, the term differently abled is nowadays more widely used in the USA to recent handicapped, as it is felt to be even less offensive and stressing one's abilities rather than inabilities. Public speakers (especially in inaugural and other official addresses) try to avoid politically incorrect expressions.

However, a language-user and professional translator has to be aware of humorous expressions that take political correctness to a ridiculous extreme. Among these are: vertically challenged (short), differently sized (fat), economically exploited (poor), involuntarily leisured (unemployed) and even domestic operator (housewife). 


\section{Follow-up}

1. Think about the cultural and technological borrowings from the other countries to the USA/the world. Complete the table with the following words:

\section{- horse raising \\ - cattle raising \\ - shepherding}

\begin{tabular}{|c|c|c|c|}
\hline Nationality & $\begin{array}{c}\text { Technologies } \\
\text { Inventions }\end{array}$ & $\begin{array}{l}\text { Holidays } \\
\text { Customs }\end{array}$ & $\begin{array}{c}\text { Cultural } \\
\text { Institutions }\end{array}$ \\
\hline
\end{tabular}

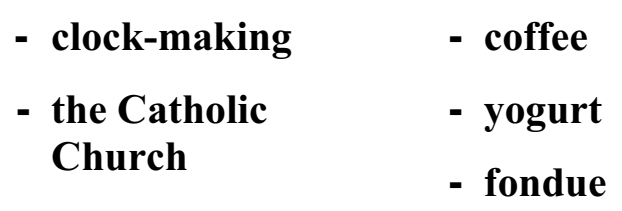

- labour unions

the English

the Swiss

the Turks

the Irish

the Slovaks 


\section{The Composition of US Society}

E pluribus unum - one from many

(The Great Seal of the USA)

In this chapter you will learn:

- What is a stereotype?

- What is a national stereotype?

- What are some generalizations referring to the American culture?

$\begin{array}{ll}\text { Study and explain the following terms: } & \\ \text { stereotype } & \text { direct discrimination } \\ \text { positive stereotype } & \text { smiling discrimination } \\ \text { negative stereotype } & \text { mainstream } \\ \text { generalization } & \text { marginal group } \\ \text { minority } & \text { race } \\ \text { visible minority, invisible minority } & \text { ethnicity }\end{array}$

\subsection{Who are the Americans? Popular Stereotypes about the USA}

Teaching the subject of cultural studies inevitably includes some generalizations, for example drawing general conclusions from case studies and individual facts. Such generalizations, however, are predetermined by the very nature of cultural studies; studying culture is to some point subjective. Aristotle disputed the aspects of precision in various sciences in The Nicomachean Ethics: "We must not expect more precision than the subject-matter admits." Thus, he continues, it is as unwise to expect an approximate outcome from a mathematician as it is to ask for precise reasoning from a rhetorician. Academic explorations of other cultures are thus inevitably based on some subjective grounding, such as case studies (SK: prípadové štúdie); nevertheless, professional researchers should distinguish between ungrounded overgeneralizations and necessary, well-evidenced ones. Renowned Nigerian author and human rights activist Chinua Achebe also warns against stereotypes:

"The whole idea of a stereotype is to simplify. Instead of going through the problem of all this great diversity - that it's this or maybe that - you have just one large statement; it is this."

One way of defeating stereotypes is to learn more about the issue in question, and to use the stereotypes not as a shortcut to simplified and hasty conclusions but as results of grounded research. This is also one of the aims this chapter sets for itself.

A stereotype is generally defined as an "image, idea, character, etc. that has become fixed or standardized in a conventional form without individuality (and is therefore perhaps false)." People who think stereotypically usually use phrases such as: "all Americans tend to...", "the Asians never...", "The Blacks always..." and "I can spot a gay man when I see one." Some traditional stereotypes relate to gender and appearance, for example: Men are better drivers than women; all blondes are dumb. 
A cultural stereotype is a culturally based belief (e.g. one referring to attributes of culture including race, ethnicity, religion, sometimes also sexual orientation or appearance) that everybody who is a member of a certain group tends to behave in some fixed pattern traditionally (and often falsely) attributed to that group. Cultural stereotypes can be positive or negative, for example:

\begin{tabular}{|c|c|}
\hline POSITIVE STEREOTYPES: & NEGATIVE STEREOTYPES: \\
\hline $\begin{array}{l}\text { - All Asians are good at math. } \\
\text { - All Asians respect their elders. } \\
\text { - All black people can dance. } \\
\text { - All black people are good at } \\
\text { basketball. } \\
\text { - All Italians and French love to drink } \\
\text { lots of wine and enjoy lengthy meals } \\
\text { together. } \\
\text { - All Germans are precise and } \\
\text { punctual. }\end{array}$ & $\begin{array}{l}\text { - All black people are always } \\
\text { late. } \\
\text { - No white people can dance. } \\
\text { - All Slavic nationalities are } \\
\text { untidy and slovenly. } \\
\text { - All Russians drink lots and lots } \\
\text { of vodka. } \\
\text { - All homosexuals are } \\
\text { effeminate and have a sway in } \\
\text { their walk. }\end{array}$ \\
\hline
\end{tabular}

Needless to say, positive stereotypes can be as harmful as the negative ones. Many similar stereotypes are attributed to Americans. Americans in general are stereotypically viewed as:

\begin{tabular}{|c|c|}
\hline POSITIVE STEREOTYPES: & NEGATIVE STEREOTYPES: \\
\hline $\begin{array}{ll}\text { - } & \text { friendly } \\
\text { - } & \text { optimistic } \\
\text { - } & \text { outgoing } \\
\text { - } & \text { informal } \\
\text { - } & \text { hardworking } \\
\text { - } & \text { religious } \\
\text { - } & \text { wealthy } \\
\text { - } & \text { extravagant }\end{array}$ & $\begin{array}{ll}\text { - } & \text { loud } \\
\text { - } & \text { boastful } \\
\text { - } & \text { rude } \\
\text { - } & \text { superficial } \\
\text { - } & \text { wasteful } \\
\text { - } & \text { ignorant of other countries } \\
\text { - } & \text { disrespectful of authority } \\
\text { - } & \text { lacking class consciousness } \\
\text { - } & \text { racially prejudiced }\end{array}$ \\
\hline
\end{tabular}

It is clear that many of these aforementioned attributes (for example "loud") depend on personal taste, the eye of the beholder or one's individual experience and therefore cannot be taken objectively. For some of these stereotypes, however, there are historical reasons and explanations students of cultural studies should be aware of. Let us have a closer look at three of them: American friendliness, informality and lack of geographical knowledge:

- American friendliness: Some Europeans might find Americans extremely friendly, outgoing and informal: they almost immediately call others by their first names, they do not use the respectful second person plural used in some European languages, e.g. German and Slovak (SK: vykanie). However, a non-American person should not understand this as a sign of disrespect; the grammatical structure of the English language simply does not distinguish between a formal and 
informal way of addressing others. If an American wants to address someone more formally (e.g. a student to a teacher), they use "Mr.", "Mrs.", "Miss", "Ms." or "Professor", combined with their last names.

- American informality, disrespect towards authorities and lack of class consciousness: All these attributes are also rooted in American history. Among the most fundamental documents that helped to shape the United States, such as John Locke's The Second Treatise on Civil Government (1689), and also in the wording of key political texts such as The Declaration of Independence, the ideas of democracy and equality have been frequently pointed out. Compare, for example, several texts that shaped the thought during the period when the American nation was born:

James I of England (1610):

Kings are justly called gods for they exercise a manner of resemblance of Divine power upon earth. For if you will consider the attributes of God, you shall see how they agree in a person of a King. God hath power to create, or destroy, make or unmake at his pleasure, to give life, or send to death, to judge all, and to be judged nor accountable to none, to raise low things, and make things high at His pleasure and to God are both Soul and body due. And the like power have Kings.
John Locke: The Second Treatise on Civil Government (1689):

...Men being $[\ldots]$ by nature all free, equal and independent, no one can be put out of this estate, and subjected to other political power or another without his consent. The only way by which anyone diverts himself of his natural liberty and puts on the bonds of civil societies by agreeing with other men to join and unite into a community for their comfortable, safe and peaceable living one amongst another, in a secure enjoyment of their properties, and a greater security against any that are not of it.

\section{The Declaration of Independence} (1776):

We hold these truths to be selfevident, that all men are created equal, that they are endowed by their Creator with certain unalienable Rights, that among these are Life, Liberty and the pursuit of Happiness.

\footnotetext{
Abraham Lincoln: The Gettysburg Address (1689):

"...the government [...] of the people, by the people, for the people..."
} 
The idea of equality and democracy thus historically resonates in American society. As a result, many Americans do not respect the same sense of social hierarchy as some European and Asian cultures. For example, in a US classroom, one may observe a more democratic atmosphere than in most Slovak classrooms: students interrupt the teacher more often, ask more questions and disagree more frequently than in a traditional Slovak classroom. Also, it is quite rare to see public school facilities (such as restrooms and school canteens) divided into teachers' and students' sections - every space is equally accessible to everybody.

There is at least one more stereotype that is explainable in the broader context of American history and lifestyle - a certain reported ignorance of other countries. Popular media and dubious opinionmakers such as YouTube contributors often mock the ignorance of certain people they stop in the street and ask various political and geographical questions. However, when thinking of what an average American in the street knows about the other countries, one should take into consideration at least a couple of phenomena that affect the relationship between the USA and the rest of the world:

1. The size of the USA: Some people forget to realize the size of the USA. It is a "continent-sized" country with a land area of $3,615,122$ miles $^{2}\left(9,363,123 \mathrm{~km}^{2}\right)$. Here are some more geographical facts that make the enormous size of the USA more manageable:

- The USA is about the same size as the entire European continent; the Americans do not even use car number plates designating their entire country (as the Europeans used to in some countries prior to EU unification);

- San Francisco is about as far away from New York (4,500 km) as Paris from Baghdad;

- Between San Francisco and New York, there are four time zones; a fast train (traveling 96 $\mathrm{km} /$ hour) takes more than 48 hours to cross the USA; a passenger jet takes about 6 hours;

- Montana is about the size of Germany, Texas is the size of France, Arizona is the size of Italy, Maine is the size of Hungary, and West Virginia is a bit larger than Slovakia.

Therefore, American geography classes are naturally more oriented towards the geography of the USA. Moreover, the population of the USA is more than $300,000,000$. Therefore, the key word to understand the American way of life is diversity.

2. Language: Imagine if the same language were used from France, to Poland, Russia and Turkey the same area the English language covers in the USA. Consequently, the Americans do not have the same urge to learn foreign languages and, therefore, do not explore other cultures to the extent of regular language learners.

3. Lack of national curriculum: American schools follow various curricula with different time and scope allocated for geography and world politics. Thus some American students might be very competent in world history and politics; others might be more aware of the US geographical and political circumstances.

4. Pragmatic educational philosophy of US schools: Instead of theoretical information, the American way of learning is more focused on a practical, hands-on approach to teaching and learning. Instead of memorizing a lot of data regarding various countries and political institutions, students at American schools are often asked to prepare various projects or solve practical problems. Thus, some American students are more prepared to explain how the system works than to provide its historical and theoretical background.

Understanding these differences and analysing their effects on successful communication are some of the goals of intercultural studies. Intercultural studies help language learners to become more competent communicators and to acquire intercultural communicative competence. $G$. Chen and 
W. Starosta define intercultural communicative competence as "the ability to effectively and appropriately execute communication behaviours that negotiate each other's cultural identity or identities in a culturally diverse environment." R. Wiseman further notes that "interactive communicative competence includes many data, skills, and motivation necessary for effective and appropriate interaction with people coming from different cultures and environments." "Intercultural communicative competence also helps in analysing the situation (context) and selecting the correct mode of behaviour." Slovak researchers E. Henčeková and A. Zelenková both understand the study of interculture as an indispensable part of foreign language acquisition.

The aim of cultural studies is thus to understand cultural differences, to explore the new culture better and to learn historical and social reasons for its functioning. This will help academics as well as language users to divorce themselves from overgeneralizations, stereotypes and ungrounded opinions, to explore American culture fairly and objectively and to react accordingly in various intercultural situations.

\subsection{The American Majority and Minorities}

The USA is the third most populous country in the world (after China and India). The population of the USA is measured by a census (administered by the United States Census Bureau) every ten years. The resident population as of January 1, 2019 was estimated to be 328,231,337 inhabitants. The most densely populated states are:

\section{District of Columbia (with $10,357.7$ people per square mile)}

\section{New Jersey}

\section{Rhode Island}

4. Massachusetts

\section{Connecticut}

6. Maryland

\section{Delaware}

8. New York (with 415.3 people per square mile; the overall population of New York in 2012 was 19,570,261 people).

The demographic composition of US society is very diverse. Here are some interesting footnotes:

- Sex: There were 155.6 million females in the United States in 2009. The number of males was 151.4 million.

- Age: At age 85 and older, there were more than twice as many women as men. People under 20 years of age made up over a quarter of the U.S. population $(27.3 \%)$, and people age 65 and over made up one-eighth (12.8\%) in 2009. The national median age was 36.8 years.

- Ancestry: The United States Census Bureau defines white people as those "having origins in any of the original peoples of Europe, the Middle East, or North Africa. It includes people who reported 'White' or wrote in entries such as Irish, German, Italian, Lebanese, Near Easterner, Arab, or Polish." Whites constitute the majority of the U.S. population, with a total of 
$223,553,265$ or $72.4 \%$ of the population in the 2010 United States Census. $(72.4 \%=63.7 \%$ "White + Not Hispanic or Latino" + 8.7\% "White + Hispanic or Latino").

- Despite major changes due to illegal and legal immigration since the 1960s and the higher birth-rates of non-whites, the overall current majority of American citizens are still white and American-English-speaking, though regional differences exist.

One cannot fail to notice the rather vague and imprecise data regarding the ethnic composition of the US society. This may be because Americans can claim more than one ancestry in the census (e.g. Finnish-Indian).

Before we examine the main minorities in the US society, we need to explore some basic terms: Race refers to any of several large subdivisions of mankind seen as sharing physical characteristics, e.g. colour of skin, colour and type of hair, shape of eyes and nose. Though most scientists now consider race a social construct, Americans traditionally recognize the Caucasian/White (SK: biela, belošská rasa), Asian, Black, Hispanic, and Native American races, as well as mixed race.

Ethnicity refers to features of a national, racial or tribal group that have a common cultural tradition. Race and ethnicity may differ; for example, a Korean child adopted by Slovak parents would be an ethnic Slovak.

Some recognized minorities in the USA are:

- African Americans

- Native Americans (also called indigenous people)

- Spanish-speaking (Hispanic) Americans, including Mexican Americans (Chicanos)

- the East Asians (Chinese, Japanese, Korean, Vietnamese Americans, etc.)

Ethnically and racially diverse societies, however, face many challenges resulting from their heterogeneous composition. Therefore, a more delicate differentiation between sociological terms is necessary. Some of the new terms reflecting modern demographic and social problems include the terms: minority, visible and invisible minority, discrimination, direct and hidden (smiling) discrimination:

Minority linguistically refers to a smaller number; however, in sociological terms it relates to the way how the mainstream culture treats marginal groups. If we understand a minority as a group that does not enjoy the same rights as the mainstream (i.e. is discriminated against), then women and disabled people also qualify as minorities in the USA. Some scholars also distinguish between invisible and visible minorities: A member of a visible minority is somebody whose difference (e.g. race or religion) can be seen immediately.

Discrimination refers to when a person or a group of people are treated differently (usually worse) than the others. Racial minorities are among the historically discriminated groups in the USA. The 1960s Civil Rights Movement put an end to many forms of direct discrimination (e.g. denying AfroAmericans access to public schools, restrooms, restaurants and libraries). However, in some multicultural societies, direct discrimination has mutated into indirect forms such as "smiling discrimination.” 
Smiling discrimination (SK: nepriama, skrytá diskriminácia) denotes a concealed form of racism, such as housing and job discrimination, promotion restrictions or greater law enforcement surveillance of visible minorities. For discrimination in any of these fields, the sociologist M. Codjoe suggests the term smiling racism, which he understands as "the covert type [of racism when] persons making covert, racially biased decisions do not explicitly broadcast their intentions; instead, they veil them or provide reasons that society will find more palatable." However, once the problem has been identified and named, there is active anti-discrimination policy conducted in the USA. The government urges people via various posters and campaigns to report any form of discriminatory behaviour.

\section{Follow-up}

1. Would you agree with any of the following statements? Why? Why not? Discuss. Try to find historical, cultural and social reasons for these stereotypes:

Some people say that the Americans are:

- Optimistic

- Religious

- Hard-working
- Underdressed

- Loud

- Boastful

2. Read and discuss the Indian life and values compared to the White Man's: Chief Flying Hawk, a Sioux Indian, nephew of Sitting Bull (1852-1931). He fought at Little Big Horn:

The white people never cared for land or deer or bear. When the Indians kill meat, we eat it all up. When we dig roots we make little holes. When we build houses, we make little holes. We shake down acorns and pine nuts. But the white people plow up the ground, pull down the tree, kill everything. The tree says "Don't. I am sore. Don't hurt me." But they chop it down and cut it up. The Indians never hurt anything, but the white people destroy all. How can the spirit of the earth like the White man? Everywhere the White man has touched it, it is sore.

The Tipi is much better to live in - always clean, warm in winter, cool in summer-easy to move. The White man builds big house, cost much money, like big cage, shut on sun, can never move; always sick. Indians and animals know better how to live than white man; nobody can be in good health if he does not have all the time fresh air, sunshine and good water. If the Great Spirit wanted man to stay in one place he would make the world stand still. The White man does not obey the Great Spirit; that is why the Indians could never agree with him.

3. Read the lyrics of the famous musical West Side Story (lyrics by Stephen Sondheim and music by Leonard Bernstein) about the Puerto Ricans sharing their experience of living in the USA. Fill 
in the missing words: accent, small, fight, white, charge twice, side, wipe, shine, twelve, slamming, there, here.

1 I like to be in America,

Okay by me in America.

Ev'rything free in America.

For a

America. fee in

3 Skyscrapers bloom in America.

Have a lot soon in America.

Industry boom in America.
2 Buying on credit is so nice.

One look at us and they

I'd have my own washing machine.

What will you have though to keep clean?

4 Lots of new housing with more space.

Lots of doors in our face.

I'll get a terraced apartment.

Better get rid of your

5 Life can be bright in America - 6 Here you are free and you If you can in America. have pride-

Life is all right in America -

If you're in America.

7 Everywhere grime in America. 8 I think I'll go back to San Juan.

Organized crime in America.

I know a boat you can get on.

Terrible time in America.

You forget I'm in America.

Everyone there will give big cheer!

Everyone will have moved

4. Think about discrimination. Read the following internet "joke". What type of discrimination (direct - indirect - smiling discrimination) does it mock?

In an American school, a teacher teaches children how to spell words.

Teacher: Mary, alright, could you spell "CAT”?

Mary: See $-E i-T e e$. 
Teacher: Good little Mary, there's something sweet for you. Now, John. Could you spell "DOG"?

John: Dee-Ou-Gee.

Teacher: Bravo, John. There's something sweet for you, too... Now Xiang, could you spell "RACE DISCRIMINATION”?

- Can you guess the nationality/ethnicity/origin of students in the class?

- Are there any minorities? Are they visible or invisible?

- Why do you think the teacher asked different types of questions? 


\section{Institutions - The Political System}

...the government

of the people, by the people, for the people...

(Abraham Lincoln)

In this chapter you will learn:

- What are the basic political principles in the USA?

- What are the basic sources of law?

- How do the Republican and Democratic political platforms differ?

- What are the major political institutions and events in the USA?

\begin{tabular}{ll} 
Study and explain the following terms: & \\
\hline political platform & swing states \\
Republican, Democratic platform & winner-takes-all \\
third parties & Secretary of State \\
checks and balances & impeachment \\
the Electoral College & clemency \\
national convention & pardon
\end{tabular}

\subsection{Political Parties}

\subsubsection{Selected Historical Milestones of the US Political Parties}

Similarly to the British system, the American political system is a two-party system. Third parties (e.g. the Dixiecrats, the Prohibition Party) spring up frequently; however, they do not last long. On the issue of the difference between parties in the US, J. Allen writes:

"People who lived in the colonies tended to divide themselves into two groups. In one group were many of the wealthy landowners, professionals and business leaders. For the most part, these people supported the British colonial government. The second group was made up of shopkeepers, wage earners, and people with small farms. In many cases, these were the people who helped stir up the revolt against the British government."

The difference between the American political parties lies in the nature of their programmes (called platforms) and the political goals they want to achieve. Compare the issues that controlled the political platforms in various periods of the US history:

\begin{tabular}{|l|l|l|}
\hline No parties & $\mathbf{1 7 8 8}$ & No parties \\
\hline
\end{tabular}




\begin{tabular}{|c|c|c|}
\hline $\begin{array}{c}\text { the Federalists } \\
\text { (Followed Hamilton's policies - } \\
\text { believed in a strong central } \\
\text { government, well developed } \\
\text { business and industry) }\end{array}$ & $\begin{array}{c}\mathbf{1 7 9 2} \\
\text { Control of } \\
\text { power }\end{array}$ & $\begin{array}{c}\text { the Democratic- } \\
\text { Republican Party } \\
\text { (Followed Jefferson - } \\
\text { believed in state } \\
\text { governments, helping } \\
\text { farmers and workers) }\end{array}$ \\
\hline $\begin{array}{c}\text { In the 1830s - the Federalists were } \\
\text { replaced by } \\
\text { the Whig Party - died out in the }\end{array}$ & I950s & $\begin{array}{c}\text { In the 1830s - the } \\
\text { Democratic- } \\
\text { Republican Party was } \\
\text { replaced by } \\
\text { the Democratic } \\
\text { Party }\end{array}$ \\
\hline $\begin{array}{c}\text { In 1854 - the Republican Party } \\
\text { formed; opposing slavery. }\end{array}$ & Slavery & $\begin{array}{c}\text { (led by Andrew } \\
\text { Jackson) }\end{array}$ \\
\hline $\begin{array}{c}\text { Platforms formed: } \\
\text { immigration and state intervention } \\
\text { into the economy }\end{array}$ & Depression \\
DEMOCRATIC PLATFORM, ELECTORATE & $\begin{array}{c}\text { Gupported slavery } \\
\text { and state intervention } \\
\text { into the economy }\end{array}$ \\
\hline
\end{tabular}

Nowadays, statistically the Democrats are supported by: minorities (religious and ethnic), immigrants, intellectuals, gays and lesbians. They are generally liberal in their views. Lyndon B. Johnson, a Democratic president (1964), and his economic and social programme are good examples of democratic priorities: he wanted to create "the Great Society" where all Americans would be equal and there would be no poverty. In order to achieve this, he started the Medicare and Medicaid programmes (health programmes for people with low income), the Head Start educational programme for poor children and adjusted several laws regulating housing.

\section{REPUBLICAN PLATFORM, ELECTORATE AND SUPPORTERS:}

The Republicans are supported by WASPs, rich businessmen and skilled professionals, as well as the socially conservative, e.g. conservative Christians. They are generally moderate to conservative in their views.

\subsubsection{Republican and Democratic Political Platforms Today}


The political platforms of the Democratic and Republican parties have been formed on the basis of their historical standing and also on the basis of current social issues that resonate in American society. Compare the issues that were of top importance in the 2000 elections and where the Republicans and Democrats stood on them:

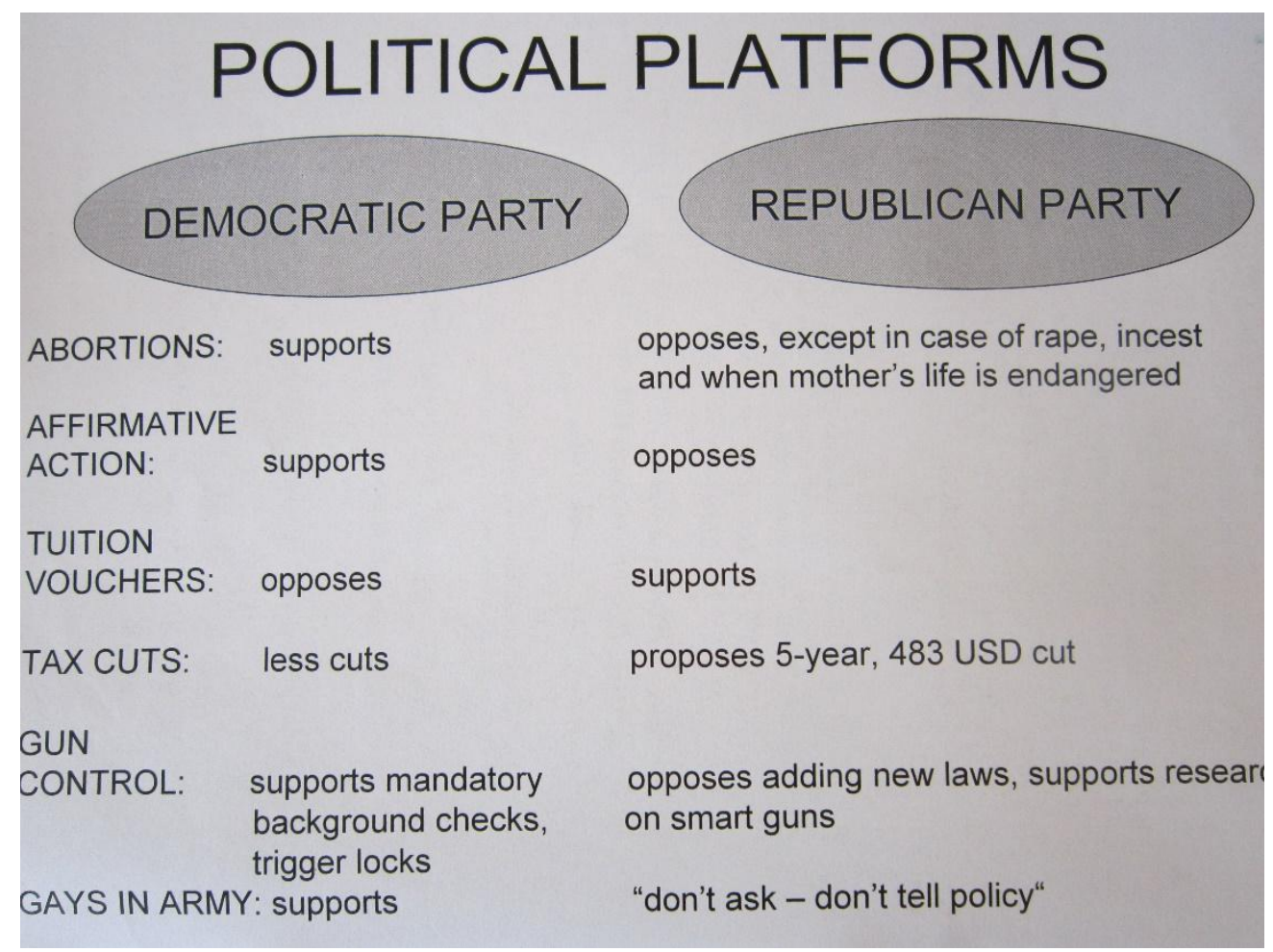

Figure 13: Political platforms in 2000

The political and economic issues that divide American society today include:

- governmental intervention into the economy; solution to the economic crisis

- drilling in Alaska: should Alaska's nature reserves be treasured as national parks or should they serve as a natural resource of oil, gas and ores?

- international politics: should the USA interfere in the conflicts in places like Syria, or maintain its military presence in Afghanistan, for example?

Organization of political parties: Both parties are organized at the national, state and local levels. That means they have a national leader, committee and mass meetings, a state leader, committee and mass meetings and a local leader, committee and mass meetings.

\subsection{Elections in the USA}




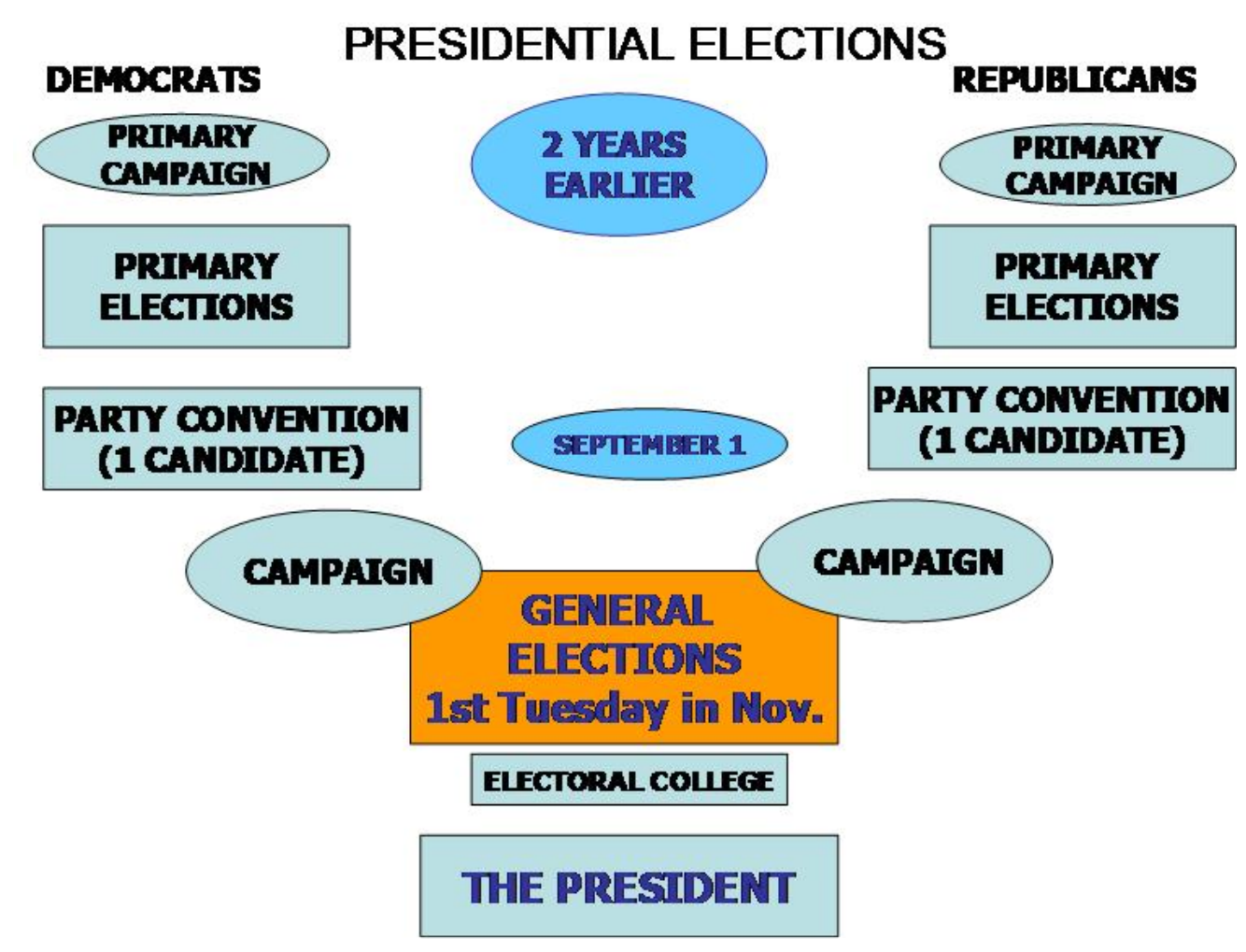

Figure 14: The Elections

Presidential elections in the USA run through three stages:

1st Stage: During the summer of the election year, the nominating process starts; each party chooses its candidate for the presidency and vice-presidency at their national convention. The national convention (SK: Národné zhromaždenie) is the means by which US political parties nominate their candidates for president and vice president. They are held every 4 years in late summer. The delegates at each convention have two aims: (1) to nominate a candidate and (2) to adopt a platform. The number of delegates as well as the system of their nomination varies from state to state.

In many states, delegates are chosen directly by voters in special primary elections (many other states have preferential primaries) (SK: preferenčné primárky). The final choice at a convention is not made until one candidate has received the votes of more than half of the candidates. If nobody gets the majority, a second ballot is held, then a third one, etc.

2nd Stage: From September to early November the two chosen candidates campaign against each other. There are usually two main presidential candidates, though the independent ones sometimes attract media attention as well.

$3^{\text {rd }}$ Stage: The date of the American presidential elections is fixed by law - every four years on the first Tuesday after the first Monday in November. On that day, people choose between the Democratic and Republican candidates. The president and the vice president are elected as a team.

The Electoral College: (SK: zbor volitel'ov): American presidents are elected by an electoral college (an institution that has survived since the founding of the nation despite more than 100 attempts to alter or abolish it) which gathers in December, long after the Americans know the outcome of the presidential elections. Each state is allotted the same number of electors in the college as it has members in the Senate and the House of Representatives. To become a president, the candidate must receive at least 270 electoral votes. On January 6 the Senate and the House of Representatives count the electoral votes of each state. If no candidate for the president has a majority, the president is chosen from among the three highest candidates.

Electoral votes and "winner takes all": 
Every state has a certain number of electoral votes, determined by population every 10 years when the US Census is conducted (See Figure 16 below). However, instead of being allocated to candidates proportionally, nearly all states (with the exception of Nebraska and Maine) use a "winner-takes-all" system. This means that the presidential candidate who wins in the state receives all of its electoral votes, regardless of the actual number of votes they received. For example, if candidate A receives $40 \%$ of the votes, candidate $\mathrm{B}$ receives $35 \%$ and candidate $\mathrm{C}$ receives $25 \%$, candidate A still gets all the state's electoral votes.

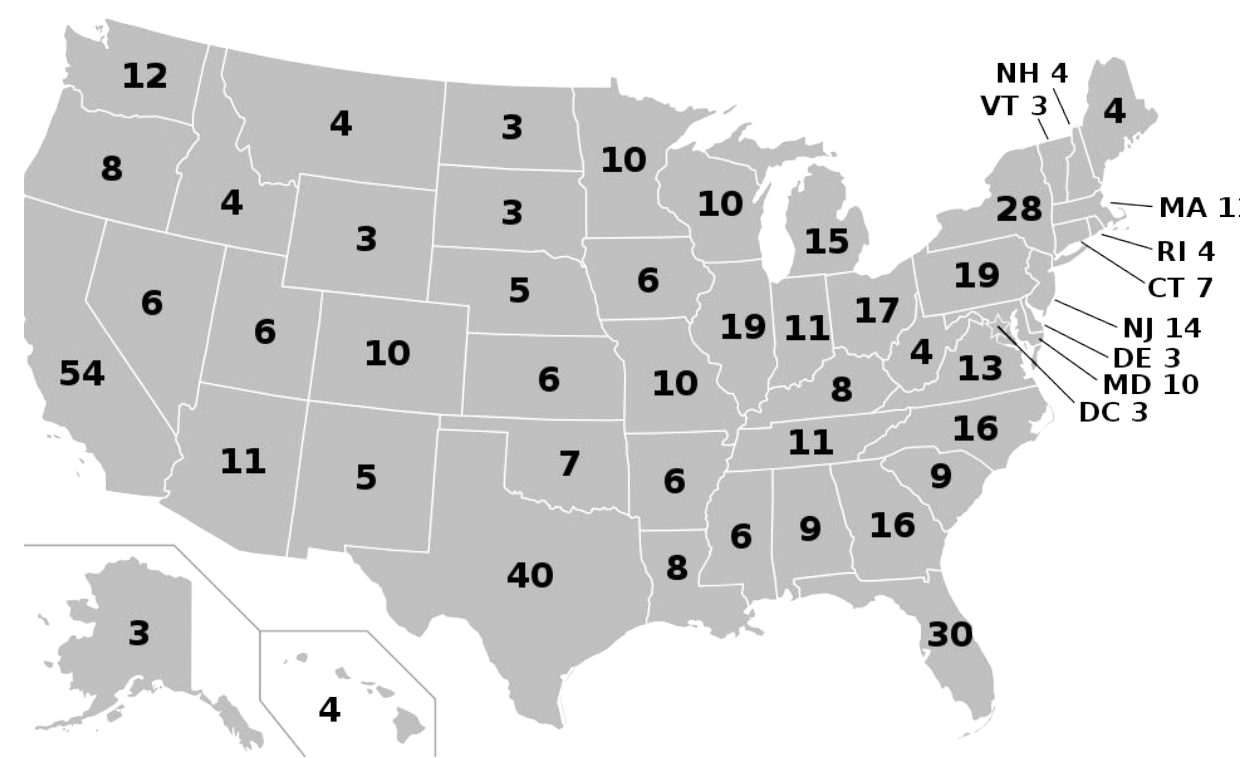

Figure 15: Electoral votes per state 2021-2028 (public domain, https://commons.wikimedia.org/wiki/File:ElectoralCollege2024.svg)

The winner-takes-all system has several significant implications:

1. Potential discrepancy between the popular vote and the election results: It is possible for a presidential candidate to gain the most electoral votes, i.e. win the election, without gaining the most actual votes, i.e. winning the popular vote. This has actually happened five times in US history, including the 2000 election of George W. Bush (who won the election despite receiving $0.51 \%$ less votes than his opponent, Al Gore) and the 2016 election of Donald Trump (who received 2.1\% less votes than Hillary Clinton).

But how is this possible? Allow me to demonstrate with a simplified example. Imagine a country called Democria, population: 300, made up of three states, all with the same population: 100 people. Based on its population, each state receives the same number of electoral votes: 10.

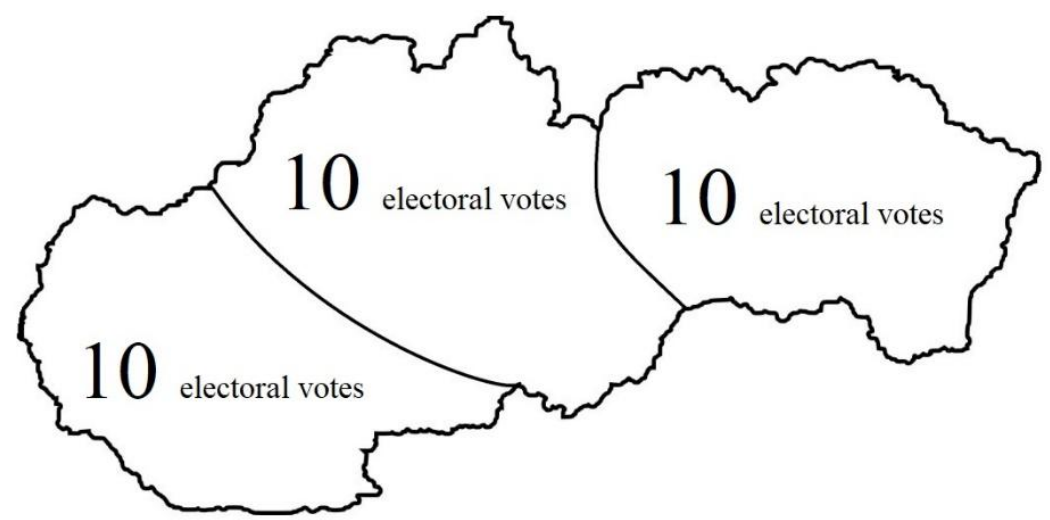


In the Democria's latest election, there were two main candidates, A and B. Let's have a look at the results of the popular vote.

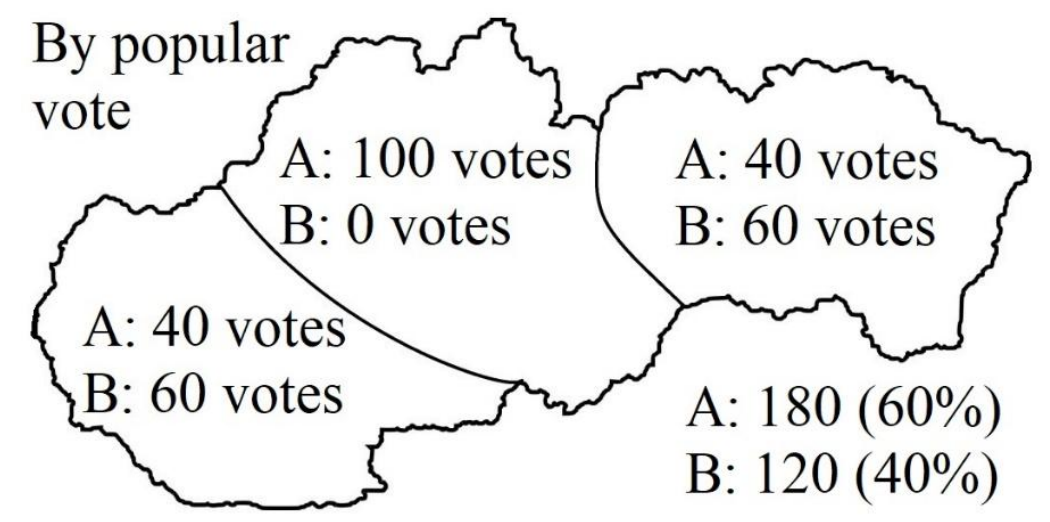

Clearly, Candidate A won more votes by a large margin. However, given the winner-takes-all electoral system, the final election results are quite different.

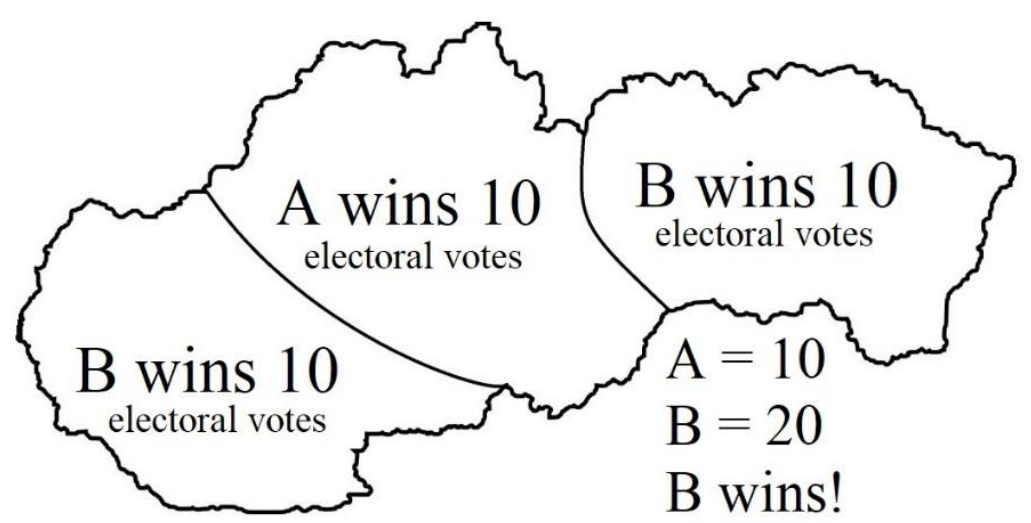

Candidate A gets 10 electoral votes for the single state it won, while Candidate B, which won in two states, gets 20 electoral votes, winning the election, despite receiving only $40 \%$ of the popular vote.

This is, of course, an extreme and simplified situation. The real-life examples have been much closer.

2. Campaign strategy: Candidates are naturally aware of the winner-takes-all system and its implications, and plan their campaigns accordingly. For example, since winning a state even by $0.1 \%$ will still earn a candidate all of its electoral votes, there is essentially no strategic difference between winning $50.1 \%$ of the vote, winning $75 \%$ and winning $100 \%$. At the same time, losing a state means losing all of its electoral votes, no matter how many or how few votes one loses by. The result is that there is no point to campaigning or otherwise wooing voters in states with a clear favorite - neither for the projected winner, nor for the projected loser.

California, for example, is the US's most populous state, with a population of roughly 39 million people in 2016. Accordingly, it is allocated the most electoral votes: 55 in total. On one hand, this might seem like a very tempting place to campaign, given the chance to win 55 electoral votes. On the other hand, California hasn't been won by a Republican since 1988, and generally goes to Democrats by a very large margin. Which for the reasons described above means that it simply isn't worth it for either party to campaign there - and they don't. In the 2016 election, Donald Trump held one event in 
California, and Hillary Clinton held none. Yet Clinton still ended up winning the state by a wide margin.

So which states do candidates campaign in? States with no clear preference, ones which could go either way, often referred to as swing states (or "battleground states"). In the 2012 elections, the presidential campaigns spent $96.2 \%$ of their television advertisement budgets in just 10 states - all of which are considered swing states: Florida, Virginia, Ohio, North Carolina, Colorado, Iowa, Nevada, Wisconsin, New Hampshire and Michigan. Some of these are even quite small, such as New Hampshire, with only four electoral votes.

Some voters see this system as unfair to the roughly $76 \%$ of Americans living in non-swing states, depriving them of presidential candidates' attention and even, according to some, disenfranchising them - "my vote doesn't count" is a common sentiment among such voters.

The winner-takes-all system is not set in stone, however; it wasn't until 1836 that nearly all the states had implemented it. And there is currently an effort underway to introduce a popular vote system which has already been ratified by 11 states.

On the other hand, legal scholars like Richard Posner see several advantages to the current system:

With winner-takes-all, the final election results are less likely to be contested, since it nearly always results in a clear winner. For example, in the 2016 election, Trump lost the popular vote, but he beat Clinton by 77 electoral votes.

In the electoral college system, as opposed to a popular vote system, candidates can't depend on winning a single region with a large population, forcing them to gain cross-country appeal.

Inauguration: According to the Constitution, inauguration of a new president always takes place at noon on January 20.

\subsection{US Political Institutions}

\subsubsection{The Executive Branch}

The Executive Branch is responsible for administering and executing the laws. The President is the head of the government as well as head of state. The President may be removed from his office by a bill of impeachment brought by the House of Representatives.

The President controls the national executive administration through the secretaries of 12 governmental departments. These secretaries are called the Cabinet. The members of the Cabinet usually belong to the President's political party. The Cabinet includes, among others:

\begin{tabular}{|l|l|l|l|}
\hline Official name & $\begin{array}{l}\text { Department } \\
\text { head }\end{array}$ & Area of authority & $\begin{array}{l}\text { Slovak counterpart } \\
\text { or translation }\end{array}$ \\
\hline $\begin{array}{l}\text { the Department } \\
\text { of State }\end{array}$ & $\begin{array}{l}\text { the Secretary of } \\
\text { State }\end{array}$ & $\begin{array}{l}\text { Advises the } \\
\text { President on foreign } \\
\text { relations, handles } \\
\text { visas }\end{array}$ & $\begin{array}{l}\text { Ministerstvo } \\
\text { zahraničných veci }\end{array}$ \\
\hline $\begin{array}{l}\text { the Treasury } \\
\text { Department }\end{array}$ & $\begin{array}{l}\text { the Secretary of } \\
\text { the Treasury }\end{array}$ & $\begin{array}{l}\text { Manages finances, } \\
\text { collects taxes, mints } \\
\text { coins and prints } \\
\text { money }\end{array}$ & Ministerstvo financii \\
\hline
\end{tabular}




\begin{tabular}{|c|c|c|c|}
\hline $\begin{array}{l}\text { the Department } \\
\text { of Defense }\end{array}$ & $\begin{array}{l}\text { the Secretary of } \\
\text { Defense }\end{array}$ & $\begin{array}{l}\text { Responsible for } \\
\text { security }\end{array}$ & Ministerstvo obrany \\
\hline $\begin{array}{l}\text { the Department } \\
\text { of the Interior }\end{array}$ & $\begin{array}{l}\text { the Secretary of } \\
\text { the Interior }\end{array}$ & $\begin{array}{l}\text { Protects nation's } \\
\text { natural resources, } \\
\text { Indian reservations }\end{array}$ & Ministerstvo vnútra \\
\hline $\begin{array}{l}\text { the Department } \\
\text { of Justice }\end{array}$ & $\begin{array}{l}\text { the Attorney } \\
\text { General }\end{array}$ & $\begin{array}{l}\text { Acts for the } \\
\text { government in legal } \\
\text { matters }\end{array}$ & $\begin{array}{l}\text { Ministerstvo } \\
\text { spravodlivosti }\end{array}$ \\
\hline $\begin{array}{l}\text { the Department } \\
\text { of Agriculture }\end{array}$ & $\begin{array}{l}\text { the Secretary of } \\
\text { Agriculture }\end{array}$ & $\begin{array}{l}\text { Aids food } \\
\text { production }\end{array}$ & $\begin{array}{l}\text { Ministerstvo } \\
\text { polnohospodárstva }\end{array}$ \\
\hline $\begin{array}{l}\text { the Department } \\
\text { of Labor }\end{array}$ & $\begin{array}{l}\text { the Secretary of } \\
\text { Labor }\end{array}$ & $\begin{array}{l}\text { Enforces laws on } \\
\text { minimum wages, } \\
\text { maximum hours for } \\
\text { workers }\end{array}$ & $\begin{array}{l}\text { Ministerstvo práce } \\
\text { (sociálnych vecía } \\
\text { rodiny) }\end{array}$ \\
\hline $\begin{array}{l}\text { the Department } \\
\text { of Commerce }\end{array}$ & $\begin{array}{l}\text { the Secretary of } \\
\text { Commerce }\end{array}$ & $\begin{array}{l}\text { Develops domestic } \\
\text { commerce }\end{array}$ & $\begin{array}{l}\text { Ministerstvo } \\
\text { hospodárstva }\end{array}$ \\
\hline $\begin{array}{l}\text { the Department } \\
\text { of Education }\end{array}$ & $\begin{array}{l}\text { the Secretary of } \\
\text { Education }\end{array}$ & $\begin{array}{l}\text { Responsible for } \\
\text { public education }\end{array}$ & Ministerstvo školstva \\
\hline $\begin{array}{l}\text { the Department } \\
\text { of Health and } \\
\text { Human Services }\end{array}$ & $\begin{array}{l}\text { the Secretary of } \\
\text { Health and } \\
\text { Human Services }\end{array}$ & $\begin{array}{l}\text { Responsible for } \\
\text { public health }\end{array}$ & $\begin{array}{l}\text { Ministerstvo } \\
\text { zdravotnictval } \\
\text { Ministerstvo (práce) } \\
\text { sociálnych vecía } \\
\text { rodiny }\end{array}$ \\
\hline $\begin{array}{l}\text { the Department } \\
\text { of Housing and } \\
\text { Urban } \\
\text { Development }\end{array}$ & $\begin{array}{l}\text { the Secretary } \\
\text { of... }\end{array}$ & $\begin{array}{l}\text { Provides adequate } \\
\text { housing for low- } \\
\text { income groups }\end{array}$ & $\begin{array}{l}\text { Ministerstvo } \\
\text { dopravy, výstavby a } \\
\text { regionálneho rozvoja }\end{array}$ \\
\hline $\begin{array}{l}\text { the Department } \\
\text { of Energy }\end{array}$ & $\begin{array}{l}\text { the Secretary } \\
\text { of... }\end{array}$ & $\begin{array}{l}\text { Develops energy } \\
\text { technology }\end{array}$ & $\begin{array}{l}\text { Falls under: } \\
\text { Ministerstvo } \\
\text { hospodárstva }\end{array}$ \\
\hline $\begin{array}{l}\text { the Department } \\
\text { of Homeland } \\
\text { Security }\end{array}$ & $\begin{array}{l}\text { the Secretary } \\
\text { of... }\end{array}$ & $\begin{array}{l}\text { Established after } \\
\text { the } 9 / 11 \text { attacks, } \\
\text { responsible for } \\
\text { domestic security }\end{array}$ & $\begin{array}{l}\text { Translated as: } \\
\text { Ministerstvo } \\
\text { vnútornej } \\
\text { bezpečnosti USA }\end{array}$ \\
\hline
\end{tabular}

\subsubsection{The Legislative Branch}

The function of the Legislative Branch is to make the laws and to finance the operation of the government through levying taxes.

The Congress is bi-cameral (SK: dvojkomorovy): it consists of the House of Representatives (SK: Snemovña reprezentantov) and the Senate. In Europe, the Czech Republic has adopted the most similar system to the US one. 
The Senate: Senators are elected for 6-year terms. The Vice President presides over the Senate. He is not one of the 100 regular members and may vote only in case of a tie (SK: nerozhodný výsledok).

The House of Representatives: The presiding officer of the House of Representatives is the Speaker of the House, elected by the members of the House at the beginning of each new Congress (on January 3 of each odd-numbered year) for a period of two years. The Speaker may vote only in case of a tie.

\subsubsection{The Judicial Branch}

The judicial branch represents the system of US courts. The highest among them is the Supreme Court, residing in Washington, DC. The Supreme Court consists of eight Justices appointed for life and one Chief Justice (SK: najvyšši sudca). It hears cases in which a state is a party or those that involve human rights, constitutional issues or relations towards other countries.

\subsection{Principles of American Democracy}

James Madison, the fourth US president, wrote in the Federalist Papers (1787-1788), "You must first enable the government to control the governed, and in the next place oblige it to control itself." There are several principles in the US government that enable the government to control itself. Three important principles of government were written into the Constitution. A fourth principle emerged through interpretation of the Constitution in the 19th century. The four principles are:

\section{- federalism}

- checks and balances

- limited government

- judicial review

\subsubsection{Federalism}

Federalism is a form of government in which the power is divided and shared by national and state governments. The Constitution (Article IV) gives the national government power in those matters that are of concern to the whole nation. All powers that are not specifically given to the national government belong to the state governments. Thus, the Americans look to the government in Washington to deal with the problems that affect the whole nation (war, for example). State governments deal with matters that seem closer to daily life, such as schools, roads and transport. Trade, however, may fall under the jurisdiction of both governments.

\section{Why was such a complex system set up?}

The writers of the Constitution (a.k.a. the Framers) were thinking in terms of a large republic. They wanted a government that would represent 13 states and the territory in the West. Interestingly, they acted against the beliefs of many important thinkers of the period, who thought that it was not possible to have a republic that covered a large land area and a large number of people. When a republic grew too large, they argued, the national government would need more power to control the nation and that would eventually infringe upon the rights of people. Therefore, the Americans chose Federalism - the system of many governments within one government.

\subsubsection{Separation of Powers - Checks and Balances}

The Constitution divided the national government into three branches: legislative; executive and judicial. Each branch was given some rights and duties. The power is divided and also shared by each branch. Therefore, it is very difficult for one of the branches to take over and become all-powerful: 
THE POLITICAL SYSTEM

\begin{tabular}{|c|c|c|c|}
\hline \multirow[t]{2}{*}{$\begin{array}{l}\text { EXECUTIVE } \\
\text { The President } \\
\text { The Vice-Pres. } \\
\text { Cabinet (15) }\end{array}$} & $\begin{array}{l}\text { LEGISLA } \\
\text { Congr } \\
\text { The House of } \\
\text { Representatives } \\
\text { (435) }\end{array}$ & $\begin{array}{l}\text { e Senate } \\
(100)\end{array}$ & $\begin{array}{l}\text { JUDICIAL } \\
\text { The Supreme Court } \\
\text { Federal Courts } \\
\text { State Courts }\end{array}$ \\
\hline & $\begin{array}{l}\text { The } \\
\text { Representative in } \\
\text { the Congress }\end{array}$ & The Senator & $\begin{array}{l}\text { (Chief Justice and } \\
8 \text { Associate } \\
\text { Justices) }\end{array}$ \\
\hline 4-year term & 2-year term & 6-year term & Appointed for life \\
\hline $\begin{array}{l}\text { Can veto laws } \\
\text { Appoints officials }\end{array}$ & \multicolumn{2}{|c|}{$\begin{array}{l}\text { - Make Federal Laws } \\
\text { - Levy fed. Taxes } \\
\text { - Declare war }\end{array}$} & $\begin{array}{l}\text { Interprets laws } \\
\text { Hears appeal } \\
\text { cases }\end{array}$ \\
\hline
\end{tabular}

Figure 16: Checks and balances

One of the basic principles of the US political system is the separation of powers called checks and balances (SK: systém kontroly a rovnováhy). It is often explained with the use of a triangular diagram:

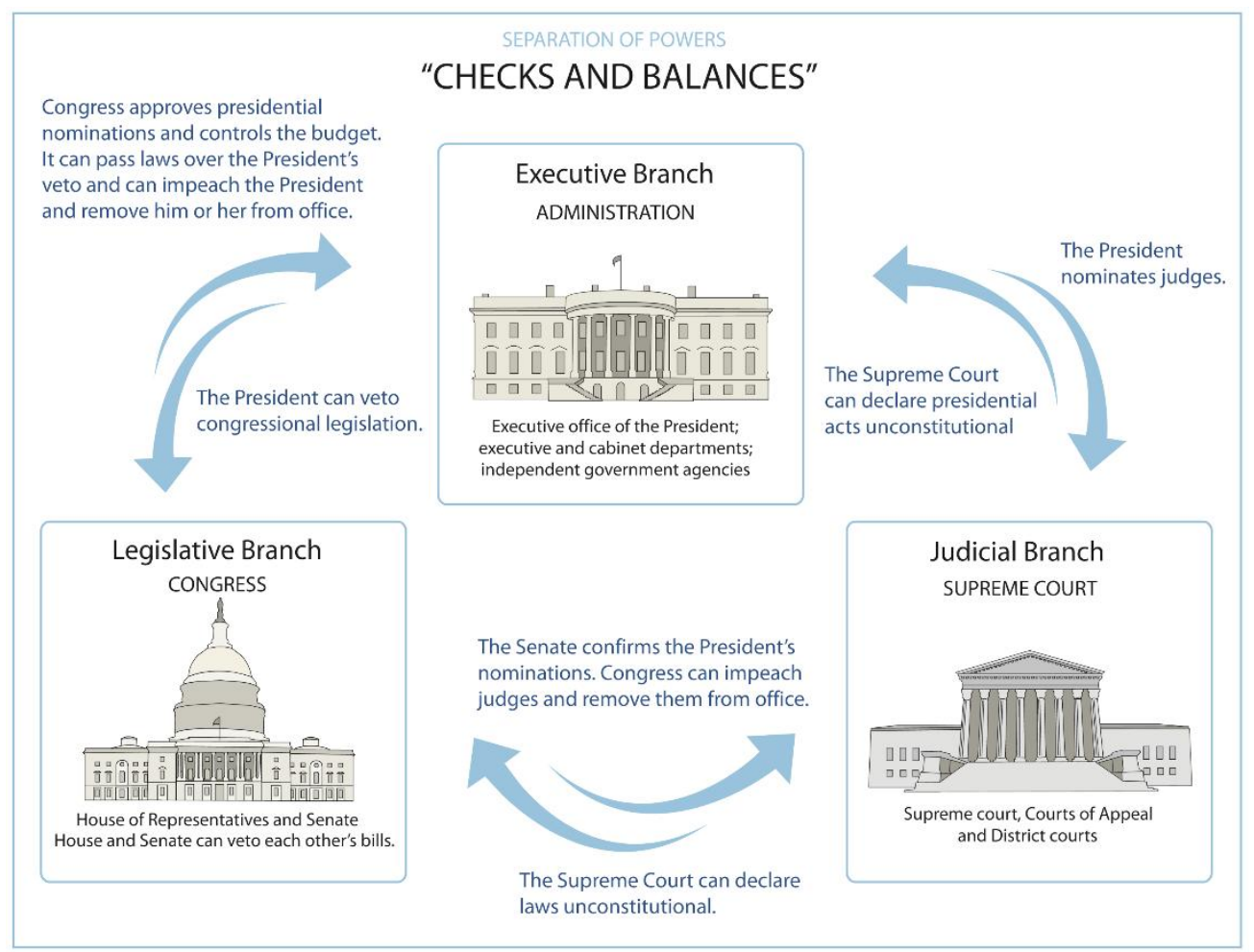

Figure 17: Checks and balances cont. Image from Leverandør: Amendor AS. https://ndla.no/subject:1:4ad7fe49-b14a4caf-8e19-ad402d1e2ce6/topic:1:48d2aed6-03db-4ba7-9670-0f7527490e43/resource:1:6410. Under Creative Commons license Attribution-ShareAlike 4.0 International. Accessed on 09.09.2021 
The legislative and judicial branches have the power to force the president to leave his job if they find his conduct unconstitutional - this trial is called impeachment. Richard Nixon was almost exposed to impeachment after the Watergate scandal, and Bill Clinton was impeached when he was accused of having a sexual affair, but was acquitted (found innocent). Donald Trump was impeached twice, accused of abuse and power and inciting an insurrection, respectively; he was acquitted both times.

The executive branch, on the other hand, has the power to grant clemency. This means the president can pardon (end the punishment of) those convicted of federal crimes, commute (reduce) their prison sentences or remit (cancel) federal fines. This power acts as a check on the judicial branch. Famously and controversially, Richard Nixon, after his near-impeachment and resignation, was pre-emptively pardoned for all crimes by his successor, President Gerald Ford.

\subsubsection{Limited Government}

Another method of preventing the national government from gaining too much power is the limitation of government, in the form of unalienable civil rights written in the Constitution. These are known as "the Bill of Rights."

\subsubsection{Judicial Review}

The principle of judicial review refers to the power of the Supreme Court of the USA to declare an act of Congress, a state or a law unconstitutional, i.e. contrary to the meaning of the Constitution and thus illegal. This principle covers laws passed by national, state and local governments.

\section{Famous US Laws}

The GI Bill of Rights (a.k.a. the GI Bill) is a US law passed in 1944. It gives financial assistance to the veterans from World War II. The money was primarily to be used for housing (in newly-built suburbs) and for education.

\section{Follow-up}

1. Decide: was it a Democrat or a Republican (or both or neither) who made the following statements?

R D Private ownership of guns shall not be restricted.

$\mathrm{R}$ D The military budget shall be reduced in favour of education.

R D Every individual is responsible for his or her health.

R D Housing is an entirely private matter.

R D Increased taxes will help society.

R D The government should not interfere with business.

R D The government should help the unemployed to join training programmes to broaden their qualifications.

$\mathrm{R} \mathrm{D}$ The decision to have children is an entirely private matter. 


\section{R D Federal administration should be simplified. \\ $\mathrm{R} \quad \mathrm{D}$ Gay people can join the army but cannot state it in their application form.}

2. Read Barack Obama's inaugural address at:

https://web.archive.org/web/20090218173557/https://www.whitehouse.gov/blog/inaugural-address/

Which parts or paragraphs...
a) ...deal with America's Puritan past and the period of exploring its territory?
b) ...deal with the US's international relations in the past?
c) ....appeal to opponents, potentially the Republican ones?
d) ...discuss governmental interference with business?
e) ...join Democratic and Republican philosophies?
f) ...appeal to small-town dwellers?
g) ...commemorate soldiers?
h) ....appeal directly to Muslims?
i) ....appeal directly to terrorists and political dissenters of the USA?
j) ...refer to global issues?
k) ...discuss international policy?
1) ...advocate religious tolerance?
m) ...discuss the future of the US policy?

Comment on Obama's style:
a) Does he use any metaphors? To what effect?
b) Does he use any other figures of speech? To what effect?
c) Does he refer to other sources or paraphrase famous thoughts?
d) Does he present facts objectively?
e) Does he present any personal views?

\section{Political puzzles}

\section{Elections:}

a) Why do some states have lots of electoral votes, while others have very few? 
b) How is it possible that five US presidents, including Donald Trump (2017-) and George W. Bush (2001-2009), won the general election without winning the popular vote? For example, in the 2016 election, Hillary Clinton received 65,853,652 votes, while Donald Trump received $62,985,134$ votes - a difference of almost three million votes.

c) Why are the results of US presidential elections so difficult to predict?

Balance of Powers, Checks and Balances:

a) The 2019 Budget: To fulfil a campaign promise, Donald Trump wants to allocate six billion USD for the expansion of the existing barrier on the US-Mexico border. What can get in the Trump administration's way?

b) Trump campaign, 2015: "Donald J. Trump is calling for a total and complete shutdown of Muslims entering the United States until our country's representatives can figure out what is going on." In January 2017, soon after his inauguration, Donald Trump signed Executive Order 13769, "Protecting the Nation from Foreign Terrorist Entry into the United States", banning travel from Iran, Iraq, Libya, Somalia, Sudan, Syria and Yemen. If understood as a "Muslim ban", this violates the free practice of religion as enshrined in the First Amendment of the US Constitution. Who can enforce the Constitution in this case?

c) September 2017: Donald Trump tries to appoint a federal judge who has no trial experience. Who has the power to prevent this inexperienced candidate from serving?

d) 2010: Barack Obama proposes the Affordable Care Act, including a mandate requiring US residents to have health insurance or pay a fine of up to $\$ 2000$ per year. Some consider this to be unconstitutional. Who has the power to stop it?

e) 2011: Barack Obama approves US participation in a unilateral NATO military intervention against the forces of Libyan leader Muammar Gaddafi. What could prevent this?

f) 2015: Congress approves the construction of the Keystone XL Pipeline, carrying oil from Canada, disturbing Lakota tribal burial grounds and putting water sources at risk. Could anyone step in to prevent this?

g) November 21st, 2018: A turkey, despite having committed no crimes, is sentenced to the death penalty. Can anyone save it from certain doom? 


\section{The Economic System}

Let me tell you about the very rich.

They are different from you and me.

Yes, they have more money.

(F. Scott Fitzgerald to Ernest Hemingway)

In this chapter you will learn:

- Which historical milestones (i.e. events) have formed the US economy?

- Which schools of economics and famous thinkers have helped to form American economic thought?

- What is the relationship between the US government and the US economy?

$\begin{array}{ll}\text { Study and explain the following terms: } & \\ \text { stock, stock market } & \text { monetary policy } \\ \text { bear market } & \text { (de)regulation } \\ \text { bull market } & \text { mortgage } \\ \text { share, share-holder } & \text { the Federal Reserve } \\ \text { fiscal policy } & \end{array}$

\subsection{Historical Milestones in the US Economy}

There were four historical periods significant for the economic history of the USA:

- the early economic history

- the period around the War of Independence

- the period between the Civil War and the First World War

- the present

Early economic history: Even though some believe there was no economy on the American continent prior to 1607, the indigenous native inhabitants of North America had various economies such as nomadic food gathering, fishing, hunting and running of agricultural communities, as well as extensive intertribal trade networks.

A similar economy was adopted by colonizers, but later it gradually developed into a more sophisticated agricultural system based on small farms. In 1607, the first settlement was founded in Jamestown; the British settlers were employed by British trading companies that had been granted trading rights by the English Crown (e.g. the Virginia Company that established Jamestown; the Massachusetts Bay Company). The colonies provided England with raw materials but were not 
supposed to compete with their home country in manufacturing. This relationship collapsed when Britain tried to imposed taxation and trade restrictions.

War of Independence period (1783-1861): After the War of Independence, the USA developed its own economic policies and markets. In 1800, the USA was still an agricultural society. Some $95 \%$ of the people lived in rural areas and the economy was based on self-sufficiency, with some exporting. However, in the 19th century, agricultural advances were combined with expanding industrial and manufacturing bases. These were aided by governmental financial support and a transport revolution which established railways, canals and road networks. As a result, agricultural productivity increased. Small farmers made use of transport and specialized in selected crops and cattle. This economic progress was affected by the Civil War when 23 states of the industrial north were opposed by 11 southern agricultural states. A northern victory led to an emphasis on the nation's industry.

The period between the Civil War and the First World War (1865-1914): In this period, the US was rapidly industrialized and became an increasingly urban country. Economic expansion was based on natural resources such as iron and other ores, as well as steam and electric power. Later, the development was taken further by technical advances: the telegraph, the radio, the typewriter, assembly-line production and interchangeable parts technology.

Since there were no trade restrictions in the internal US market, large-scale manufacturing and economy based on production and distribution were established. The export of manufactured goods became more important than the export of raw materials. Such changes led to fierce, unregulated "dog -eat-dog" competition (SK: nelútostná konkurencia). In the 19th century, there was almost no governmental control (called regulation) over the economy, meaning the economy was unregulated.

Big businesses became a central feature of American life. The expanding economy resulted in the creation of corporations (large companies made of smaller ones). They based their production and competition policies on marketing, advertising, advanced technology, cheap products, systematisation of the work process and efficient management organisation. Larger corporations were formed through mergers and takeovers, leading to giant trusts and monopolies that attempted to control competition. The political power of industrialists like the Rockefeller family and Andrew Carnegie influenced the whole economy. The period between 1865 and 1900 became famous as "the Age of Robber Barons" (SK: Vek zbohatlikov) and the "Gilded Age" (SK: Pozlátený vek).

However, monopolies proved to be anti-competitive and therefore the Sherman anti-trust law was passed in 1890. Theodore Roosevelt also tried to break up monopolies by legislation that restricted deals on prices and minimalisation of competition, as well as laws that improved working conditions (e.g. the 8-hour working day was approved). President Woodrow Wilson later passed a new anti-trust law and reduced protective tariffs against foreign competition.

Though the following decade is often referred to as "The Roaring Twenties", a time of prosperity idealised by authors such as F. Scott Fitzgerald, the 1920s "was a period of instability and hardship for many people. [...] There was over-production by factories and farms [...] and financial speculation." The economy collapsed in October 1929, when the Wall Street stock market faced the worse banking crash in its history, marking the start of the Great Depression. That was why this day in history was called "Black Tuesday".

Demands were made for more governmental regulation of business activities. President Franklin D. Roosevelt tried to solve the situation with his programme of economic renewal called the "New Deal", making him the first president who tried to substantially intervene into economy.

Roosevelt's New Deal was based the so-called "Three Rs":

- Relief: alleviating the poverty and unemployment caused by the depression

- Recovery: rebuilding the economy through government programmes 
- Reform: putting legislation in place to avoid future economic crises

The post-WWII era: The New Deal did not solve all the economic problems, some of which have continued to the present. But after the Second World War and by the 1950s, the US economy had achieved global dominance. Globalised companies such as General Motors, General Electric and Ford continued to dominate world markets for the remainder of the 20th century.

\section{The 2007-2008 financial crisis:}

On September 29th, 2008, the stock market experienced its biggest crash since 1929. This was followed by a worldwide recession, accompanied by widespread bankruptcies and unemployment. But what is often referred to as the financial crisis of 2008 began at least as far back as 2007, and its roots extend even further.

It all began with the housing market. In what was known as a housing bubble, US house prices rose continually from 1998 until they peaked in 2006. This continual rise led to optimism among homebuyers, convinced that any property they purchased would continue to increase in value, and among investors in housing (e.g. speculators, those who bought and sold houses not to live in them, but purely to make a profit) and mortgage-based (mortgage $=$ loan for buying a home) financial products, convinced that such investments would be safe and profitable.

Banks were also optimistic, willing to approve mortgages for people without the means to pay them back. The banks' rationale was that the high-risk debt of these so-called "sub-prime mortgages" could be converted into financial products and sold to larger banks or investors, who would assume the risk of the mortgages going unpaid. This risky trend further encouraged practices such as mortgage fraud (intentionally using inaccurate data to obtain a loan) and inaccurate ratings of mortgage-based financial products by ratings agencies. Meanwhile, few regulations were in place to ensure that banks could cover their losses if these risky investments didn't work out.

When housing prices started to drop in 2006, speculators began to sell their properties, and in 2008 the bubble finally burst - home prices plummeted, and banks responded by raising their mortgage clients' monthly payments. When the clients couldn't pay these higher rates, the banks foreclosed (took possession of) their homes, forcing them (or their renters) to move out, sometimes even leading to homelessness. The banks, in turn, were left with properties that were worth far less than their initial value. These cumulative losses proceeded to affect the larger banks and investors who held financial products based on these mortgages. And since these larger banks hadn't been properly regulated, they often lacked the necessary capital reserves to cover their losses. This was how the crisis on the US housing market spread first to the US financial market. And since it wasn't just US banks that had invested in the US housing market, but banks all over the world, the crisis then spread to the global financial market as a whole. When it became more difficult to acquire loans from banks, businesses suffered, leading to unemployment and general financial woe.

In 2009, Bernard Madoff was convicted in the biggest single case of financial fraud in US history, becoming the poster boy for the illegal and unethical activities enabled by the financial market's lack of regulation. His "Ponzi scheme" ended up costing his clients roughly $\$ 18$ billion, possibly more, destroying the savings of individuals and organizations around the globe. Tellingly, he had advertised his products not as risky investments, but as conservative, safe ones, attracting clients such as charity organizations.

If the New Deal was Franklin D. Roosevelt's answer to the Great Depression, George W. Bush and Barack Obama's answer to the Great Recession, as it is sometimes called, came in the form of several different laws and measures. Both presidents approved so-called "bailouts" of the failing large banks, guided by the principle that such banks were "too big to fail". In other words, if the banks were allowed to fail, the effects on the economy would be catastrophic, meaning that public funds should be used to keep them afloat. The 2008 bailout package amounted to $\$ 700$ billion; for comparison, this 
is nearly eight times the entire GDP of Slovakia. For obvious reasons, this use of public funds to prop up private businesses was controversial among politicians and citizens alike.

To avoid similar crises in the future, new regulations were also put into place, such as 2010's Dodd-Frank Wall Street Reform and Consumer Protection Act. Key measures include more oversight, new regulatory institutions, and requiring banks to maintain larger capital reserves to protect themselves in case of failure. Given the general distaste for regulation in the US business community, this law has been subjected to numerous legal challenges. The American people, for their part, remain split in terms of the views on regulating the US financial industry, with Democrats generally calling for more regulation and Republicans calling for less. The Democratic Party itself, however, generally takes a relatively lenient approach to the financial industry. In the 2016 presidential race, one of the primary criticisms of Hillary Clinton was focused on her ties to Wall Street, including campaign donations from financial institutions and individuals associated with them. For all that, after winning the election, Donald Trump would go on to take the usual antiregulatory, pro-business approach characteristic of his party: as of August 2020, Congress and Trump have eased several of its measures and plan to continue to do so.

The Federal Reserve: One of the main institutions responsible for regulating the US financial industry is the Federal Reserve Bank (often called "the Fed"), which decides the interest rates of minor banks and tells commercial banks how much money they must keep as a reserve. Given its responsibilities and independence, some scholars have even (albeit controversially) referred to it as the fourth branch of government.

US Stock Market: A "bull market" refers to a situation in the stock market when people known as "bulls" who buy shares in order to sell them later with profit. 


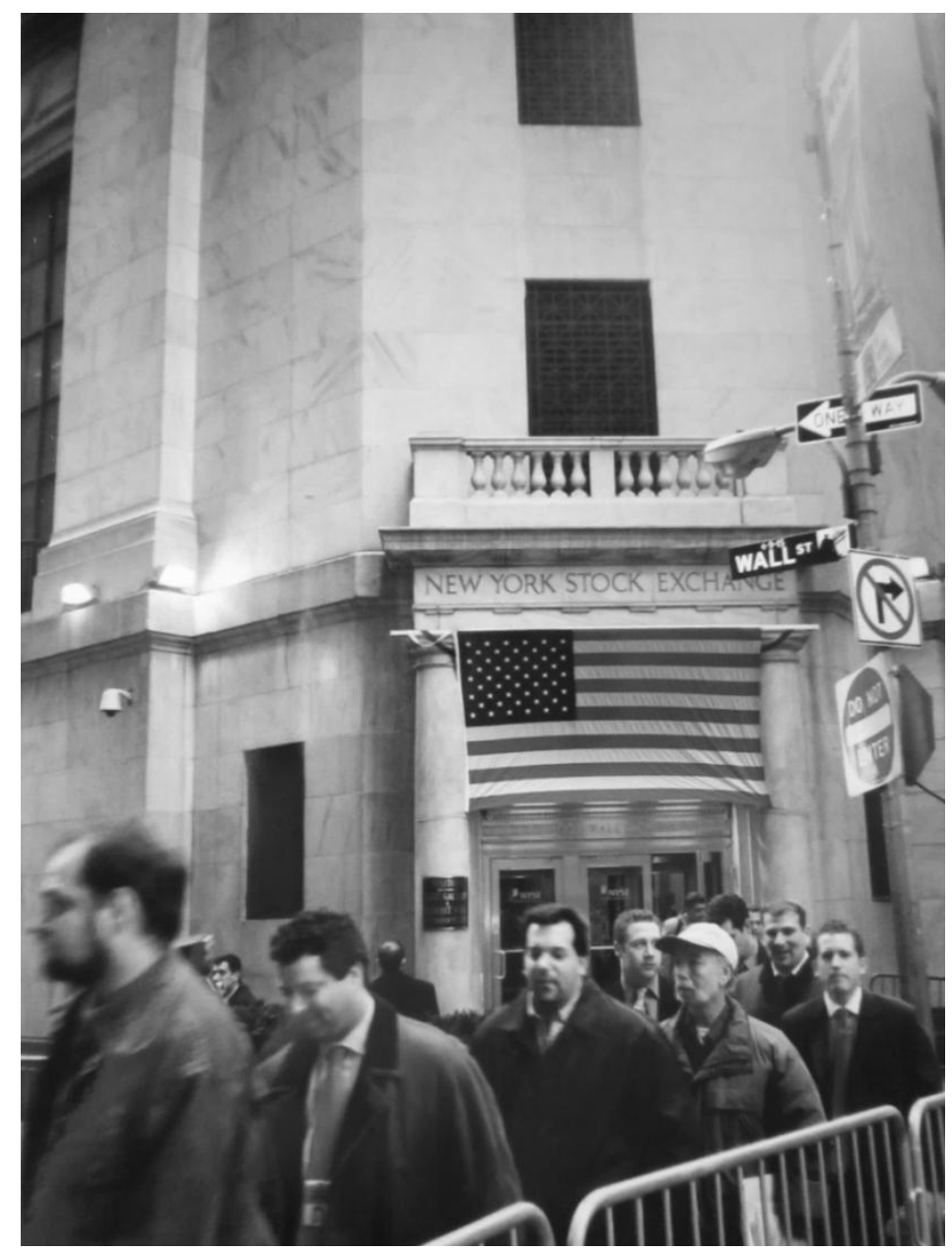

Figure 18: US stockbrokers rushing back home after a busy day. Photo: Jana Javorčíková.

US Money and Taxes: The US coins are called: pennies (.01 dollar, or one cent), nickels (.05), dimes (.10), quarters (.25), half-dollars (.50) and dollars. Every month, US employees are given a paycheck by their employers. Every year, they also receive a W-2 form (SK: podklady pre daňové priznanie) for tax purposes.

\subsection{Economic Schools and Famous Thinkers who have Influenced US Economic Thought}

Educational writer Norman Lunger notes that there are four main questions that dominate economic thought. These are:

- What is the role of the government in the economy?

- Should the government protect the economy or allow free trade?

- Should the government support big businesses or small enterprise?

- What should the relationship between management and labour be like?

Answers to these questions fundamentally distinguish various schools of economics and economic thought.

Adam Smith was a Scottish philosopher who advocated minimal intervention of the government into economy (i.e. deregulation). This theory became famous as laissez faire (the "leave it alone" principle, also called "free enterprise" and "free market") and it allows private interests maximum freedom in their enterprise, i.e. free competition of companies with each other. Smith argued that "the actions of private individuals, motivated by self-interest, [work] together for the greater good of the society, as if individuals were guided by an invisible hand." The "invisible hand of the market" 
metaphor became a popular phrase to describe the free enterprise philosophy. According to Smith, the market is self-regulating; inefficient businesses die out and only the perfectly functioning ones survive the economic competition. Smith published his ideas in the treatise known under the shortened title The Wealth of Nations (1776). His philosophical musings can be summed up as follows: "People are naturally selfish. When they engage in manufacturing or trade, they do so in order to gain wealth and/or power. This process should not be interfered with because, despite the selfinterest of these individuals, their activity is good for all society. The more goods they make or trade, the more goods people will have. The more people who manufacture and trade, the greater the competition. Competition among manufacturers and merchants helps all people by providing even more goods and probably lower prices. This activity creates jobs and spreads wealth.”

Benjamin Franklin (1709-1790) was a writer and inventor; however, he perpetuated the "American model" of success. In his Autobiography (1791) he suggested a model of self-improvement based on hard work, frugality and practicality. He also pointed out individualism and liberty as essential human desires in order to pursue happiness. Franklin believed that when following these principles, a businessman can be moral and honest. He coined many sayings and proverbs celebrating frugal and economical life, for example:

- Early to bed and early to rise makes a man healthy, wealthy and wise.

- Time is money.

- $\quad$ There will be sleeping enough in the grave.

- A penny saved is a penny earned.

These sayings grew very popular and became a part of the American cultural heritage; they also comprise basic American beliefs and principles.

Thomas Jefferson (1743-1826) was not only a politician, president and inventor, but he also explored many philosophical and ethical ideas about how to achieve maximum wealth for individuals and the society. He believed in the so-called "yeoman farmer" (SK: slobodný malorolník), an independent, self-sufficient farmer.

John Stuart Mill (1806-1873) was an English philosopher and economist. He published Principles of Political Economy where he, just like Adam Smith, perpetuated ideas of laissez faire. He also explored the philosophy of utilitarianism, i.e. a pragmatic way of solving problems. Mill and Smith represent the "Classical School" of economics.

Alfred Marshal (1842-1924) was an English economist, a representative of the "Neoclassical School" of Economics who greatly influenced US political thought. In his book Principles of Economics (SK: Zásady ekonomiky), he expresses his belief in competitive markets, low taxes, minimal governmental intervention and equilibrium between supply and demand.

Horatio Alger (1832-1899), a 19th century author, wrote a series of popular books for boys. In these, he employed the very American topic (introduced by Benjamin Franklin) of "rags to riches". He wrote about young men who gained success via hard work and frugal living. These ideas still resonate in American society today; many people view America as a country where one can "get rich quick" or can move upwardly "from a shoe shiner to the president."

Asa Grigs Candler (1851-1929), founder of the Coca Cola Company.

Henry Ford (1863-1947) was not a professional economist; however, he greatly influenced the American economy. Ford was an entrepreneur who employed mass production technologies (such as the assembly line) in order to make his famous Model T (called "Tin Lizzie") automobile. What is more, due to his generous salaries, Ford's employees were able to buy the cars and thus formed a very numerous group of customers. His rather controlling view of the world is well illustrated by one of his quotes: "Any customer can have a car painted any colour that he wants as long as it is black." 
John Maynard Keynes (1883-1946) was originally an English economist, though his ideas were influential internationally. His basic economic philosophy can be summed up as follows: "When demand lags because people lack money to buy things they need, Government should run a deficit that is, spend more than it takes in from taxes - to provide economic stimulus." Keynesian economic thought supported a fusion of protectionism and regulation. Many of his teachings have been redebated during the present crisis.

Milton Friedman (1912-2006), anti-Keynesian, Ronald Reagan's economic adviser and the primary exponent of neoliberal economics, the most influential economic philosophy of the late 20th and early 21 st centuries.

Bill Gates (1955-) started the Microsoft Corporation with Paul Allen when he was only nineteen. 


\section{Follow-up}

1. Can you write out a check?

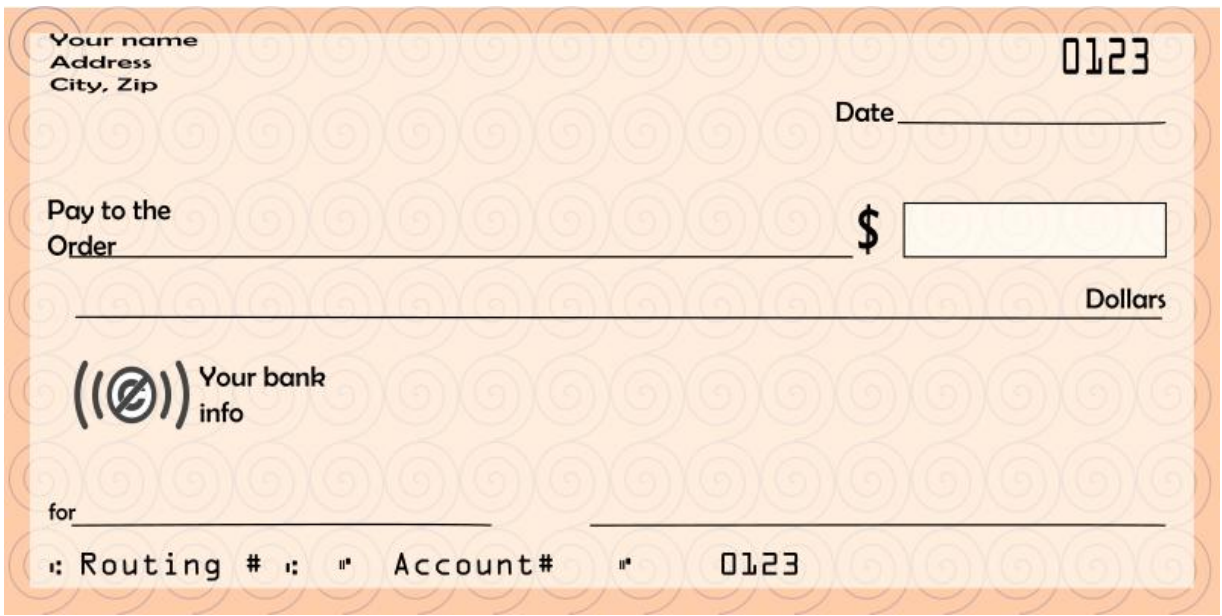

Image source: openclipart.org (public domain).

2. Discuss some of the maxims of US enterprise:

a. The customer is always right.

b. Work hard and you will be rewarded.

c. Life doesn't owe you a living; you have to work for it.

3. What, in general terms, caused the 2008 financial crisis? Name at least two factors. 


\section{The Legal System}

There is no method

by which men can be both

free and equal.

(Walter Bagehot)

In this chapter you will learn:

- What are the main legal documents in the USA?

- What are the sources of US law?

- What are the main issues in the US Constitution? How does it differ from the Slovak one?

- What are the main legal institutions in the USA?

\section{Study and explain the following terms:}

case law, common law, precedent

the law of equity

jury, grand jury, petit jury

judicial district

district court, Supreme Court civil law

criminal law

misdemeanour

felony

social security number

\subsection{Basic Legal Documents}

There are at least three sources of American law. The gist of the US legal philosophy derives from the Puritan Scriptures and later the Christian Bible regulating what is right (meaning acceptable, desirable) and wrong (meaning dangerous and punishable) in society.

Later, other sources of law emerged. In legal terminology they are called statutory laws, common laws and the law of equity. Statutory laws (SK: štatutárne zákony) are made by legislative bodies, usually in the form of written laws. Common law (also called "case law"; SK: obyčajový zákon) is a phenomenon inherited from England. Allen writes, "Beginning almost 1000 years ago, English judges decided cases according to the customs of their day. Slowly these decisions were built into a vast body of law. Judges were able to turn to this body of law for help in making new decisions. Gradually the process of turning back to the decisions made by earlier judges became an accepted practice in English courts." Common law system or, in other words, the system of precedents was brought to colonies in the early colonial times and is still widely used in state courts. The most famous precedents include:

Plessy v. Ferguson (1896) This case decided that segregation in public places was legal provided that black and white people were given the same quality service. This became famous as the separate but equal principle. 
Brown v. Board of Education of Topeka (1954) ended the separate but equal doctrine and led to the illegalisation of segregation at US public schools.

Miranda v. State of Arizona (1955) was the court decision that determined the rights of those arrested. They must be informed of their rights, such as the right to have a lawyer and the right to remain silent.

However, mechanical application of common law could potentially lead to injustice. Therefore, equity law enables judges to depart from the strict meaning of common and statutory law (Ibid.).

Most of Americans' rights and freedoms are guaranteed by the Constitution, written in 1787 .

The US Constitution is the oldest written constitution in the world. It consists of:

- the Preamble;

- the Articles;

- 27 amendments. The first 10 amendments are called the "Bill of Rights" (SK: Listina práv a slobôd). The style and formulation of these amendments proved to be so effective that very few changes were later required and therefore many believe that the USA has one of the most sustainable legal documents in the world.

I. Freedom of Speech, Press, Religion, Assembly and Petition Congress shall make no law respecting an establishment of religion, or prohibiting the free exercise thereof; or abridging the freedom of speech, or of the press; or the right of the people peaceably to assemble, and to petition the Government for a redress of grievances.

II. Right to keep and bear arms

A well-regulated militia, being necessary to the security of a free State, the right of the people to keep and bear arms, shall not be infringed.

III. Conditions for quarters of soldiers

No soldier shall, in time of peace be quartered in any house, without the consent of the owner, nor in time of war, but in a manner to be prescribed by law.

IV. Right of search and seizure regulated The right of the people to be secure in their persons, houses, papers, and effects, against unreasonable searches and seizures, shall not be violated, and no warrants shall issue, but upon probable cause, supported by oath or affirmation, and particularly describing the place to be searched, and the persons or things to be seized.

V. Provisions concerning prosecution

No person shall be held to answer for a capital, or otherwise infamous crime, unless on a presentment or indictment of a Grand Jury, except 
in cases arising in the land or naval forces, or in the militia, when in actual service in time of war or public danger; nor shall any person be subject for the same offense to be twice put in jeopardy of life or limb; nor shall be compelled in any criminal case to be a witness against himself, nor be deprived of life, liberty, or property, without due process of law; nor shall private property be taken for public use without just compensation.

VI. Right to a speedy trial, witnesses, etc.

In all criminal prosecutions, the accused shall enjoy the right to a speedy and public trial, by an impartial jury of the State and district wherein the crime shall have been committed, which district shall have been previously ascertained by law, and to be informed of the nature and cause of the accusation; to be confronted with the witnesses against him; to have compulsory process for obtaining witnesses in his favor, and to have the assistance of counsel for his defense.

VII. Right to a trial by jury

In suits at common law, where the value in controversy shall exceed twenty dollars, the right of trial by jury shall be preserved, and no fact tried by a jury shall be otherwise reexamined in any court of the United States, than according to the rules of the common law.

VIII. Excessive bail, cruel punishment

Excessive bail shall not be required, nor excessive fines imposed, nor cruel and unusual punishments inflicted.

IX. Rule of construction of Constitution

The enumeration in the Constitution, of certain rights, shall not be construed to deny or disparage others retained by the people.

X. Rights of the States under Constitution

The powers not delegated to the United States by the Constitution, nor prohibited by it to the States, are reserved to the States respectively, or to the people.

However, nowadays some terms of the Bill of Rights provoke controversy. For example, the Fifth Amendment is often used by suspects who are afraid to answer those questions that could incriminate them (saying "I take/plead the Fifth"). The Fifth Amendment also regulates the rights of suspects and convicts, saying "nor shall any person be subject for the same offense to be twice put in jeopardy of life or limb." However, that does not include DNA testing technology (put into practice in 1993) and now many cases are re-investigated after the fact.

The Eighth Amendment also provides some room for interpretation. US citizens cannot be exposed to cruel and unusual punishment; however, in the American military prison Guantanamo (also called "Gitmo"), certain interrogation practices (e.g. a technique called waterboarding) were classified as contradicting the Eighth Amendment and thus declared illegal. The death penalty is also taken as an example of cruel and unusual punishment. 
Freedom of expression is another debatable issue in the USA, and it is not upheld in every situation. For example, the courts may order newspapers not to print an article if national security is involved. Also, libel is illegal. Oliver Wendell Holmes said, "The most stringent protection of free speech would not protect a man falsely shouting fire in a theater and causing a panic."

The most controversial, however, is the First Amendment that concerns the freedom of worship. It guarantees freedom of religion, saying that "Congress shall make no law respecting an establishment of religion, or prohibiting the free exercise thereof." Even religious communities, such as the Mormons (members of a Christian denomination also called Latter-Day Saints who are mostly concentrated in Utah. They believed in teetotalism and polygamy), and very extreme religions like the Amish, Hutterites (Protestants, a division of Anabaptists, first established in former Czechoslovakia, now living mainly in the Dakotas and Montana who believe in plain life without modern technological inventions), or Hasidim are tolerated. However, the statement itself is a contradiction and might lead to many ambiguities when put into practice. For example, any form of schoolorganized worship or prayers is prohibited in public schools in the USA, which may seem to contradict the right of an individual to "free exercise" of their religion; however, some schools also offer a "prayer club" where individuals can practice their respective religions.

\subsection{The Constitutional Liberties and Famous Legal Principles}

There are several liberties granted by the US Constitution:

- habeas corpus (SK: právo na proces);

- protection from ex post facto laws (SK: retrospektívny zákon);

- protection from bills of attainder (SK equivalent relates to the issue: ochrana pred kolektívnou vinou);

- limited definition of treason (SK: špecifické vymedzenie vlastizrady).

Habeas corpus (comes from a Latin phrase meaning "you should have the body brought before a judge") is granted by Article I of the Constitution. It requires that "an arrested person must be brought before a judge who will decide whether or not the person should be kept in jail before being tried. The purpose of Habeas Corpus is to prevent unreasonable imprisonment." Habeas corpus may be suspended only in times of rebellion or invasion, or when public safety requires it.

A bill of attainder is a law that singles out one person or group of people (e.g. gays, Communists) and punishes them without a trial by jury.

An ex post facto law is "a law that punishes a person for doing something that was not illegal when the person did it."

Limited definition of treason: Treason is the only crime defined in the Constitution, in Article III:

Treason against the United States shall consist only in levying war against them, or in adhering to their enemies, giving them aid and comfort. No person shall be convicted of treason unless on the testimony of two witnesses to the same overt act, or on confession in open court.

The Congress shall have power to declare the punishment of treason, but no attainder of treason shall work corruption of blood, or forfeiture except during the life of the person attained.

Why is treason defined in such great detail? Historically, treason has been one of the most disputable crimes. Any dissenter with the crown or ruler, anybody who justly criticized the government could be accused of treason. Therefore, the US constitution framers secured the rights of people regardless of their political standing. The definition of treason was greatly re-debated in the 1950s during the "McCarthy 
Era" (also negatively called the "Red Scare"), when many famous people (dramatist Arthur Miller, for example) were accused of sympathizing with and helping the Communist Party. This era, however, is now criticized as disrespectful of the third Article.

\subsection{Legal Institutions}

The Slovak and the US legal systems are completely different entities; thus the Slovak translations and equivalents in this sub-chapter refer to the most closely related areas in judicial institutions in both countries.

Who works at the US courts? Some of the people who work in legal institutions are: judges, justices (nine judges of the Supreme Court), lawyers (also called attorneys-at-law), defense attorneys (representing the suspect in courts) and prosecutors. In civil cases, the person who claims to be wronged is called the plaintiff (SK: žalobca). The person who is accused of a crime or trespass is called the defendant (SK: obžalovaný).

The US legal institutions consist of:

- the Supreme Court (SK: Najvyššsi súd);

- 94 district courts situated in various states of the USA (SK equivalent: Okresný súd);

- 12 courts of appeal (SK: Odvolacie súdy; in Slovakia, their function is carried out by Krajské súdy).

Here are several notable points regarding the US legal institutions:

\section{The Supreme Court in Washington, DC:}

- has the power to review any executive or legislative action or law and declare it unconstitutional;

- recently, the Supreme Court has received on average a hundred petitions a week to hear appeals from lower federal courts or to take cases directly to itself;

- decides on about a hundred cases a year;

- one of the nine Justices is appointed to write the Court's reasoned opinion, and when each Justice has had time to study the draft opinion, a vote is taken.

\section{4 district courts situated in various states of the USA:}

- 94 courts are situated in all parts of the USA, with each state having at least one court.

- District courts are trial courts in which a single judge or jury decides each case).

- District courts try cases regarding issues such as taxation, administrative regulations, and bankruptcy but also robbery or currency fraud. Some states also have specialised family courts (which deal with issues such as custody and divorces) or small claims courts (which deal with civil claims of small amounts of money). Family courts and small claims courts lack an exact counterpart in Slovakia, where the institution called Okresný súd hears these types of cases. 


\section{US Courts of Appeals:}

- The Courts of Appeals consist of 12 courts sitting in 11 judicial circuits and the District of Columbia (Washington, D.C.).

- These courts (with from three to five judges) mainly hear appeals of the decisions of the US District Courts.

- Most of their decisions are final and set a precedent for similar cases in the future.

These courts hear cases according to their nature. Just like in Slovakia, cases are divided into criminal and civil. Civil cases involve issues such as child custody and inheritance. Criminal cases treat crimes, of which there are two kinds: felonies and misdemeanours.

Felonies (SK: trestné činy) are serious violations of laws such as hijacking, kidnapping, robbery, assault, forgery, murder, and rape. Misdemeanours (SK: priestupky) represent less dangerous types of crimes such as petty larceny, minor car accidents etc. In extreme cases, 38 states utilize an extreme form of punishment - capital punishment, also called the death penalty. The methods of execution vary from state to state (electrocution, gas injection, electric chair, hanging, firing squad and gas chamber) and many people object to these as "cruel and unusual forms of punishment." A prisoner who is on death row, however, can be pardoned any time before the execution. One argument against the death penalty is that there have been several cases in US history of miscarriage of justice (SK: justičný omyl) - the irreversible mistake of executing an innocent person.

There is also a special legal practice in the USA called trial by jury (SK: porota). Though the Slovak legal system does not use it, we might be familiar with it from TV series and films (Twelve Angry Men starring Peter Fonda might be most famous of them). The right to a trial by jury is guaranteed by Article III of the Constitution, and it is also mentioned by the Sixth and Seventh Articles. There are two kinds of juries:

- grand jury (SK: vel'ká porota) - serves in criminal cases and may have 12 to 23 members

- petit jury (SK: malá porota) - also called a "trial jury"; generally has 12 members and serves in civil cases

Any adult (including those without legal education) with a social security number may become a member of the jury. Their job is to hear charges, examine evidence and hand down a verdict which has to be either unanimous or a majority verdict, provided that no more than two of the jurors disagree. There must be a trial judge present, who instructs the members of the jury about how laws should be applied. Any person who pleads "not guilty" can be tried by jury.

\section{Follow-up}

1. Decide which of these are classified as felonies and misdemeanours:

$\begin{array}{llll}\text { 1. } & \mathbf{F} & \mathbf{M} & \text { minor traffic offense } \\ \text { 2. } & \mathbf{F} & \mathbf{M} & \text { petty larceny } \\ \text { 3. } & \mathbf{F} & \mathbf{M} & \text { shoplifting }\end{array}$


4. $\quad$ F $\quad$ M keeping goods unlawfully

5. $\mathbf{F}$ M extortion of money

6. $\mathbf{F}$ M using threats

7. $\mathbf{F}$ M robbery

8. $\mathbf{F}$ M hold-up

9. $\mathbf{F}$ M threatening with a gun

10. F $\mathbf{M}$ libel

11. F M hijacking

12. $\mathbf{F}$ M trespassing on private land

13. F M blackmail

14. F $\mathbf{M}$ smuggling

15. $\mathbf{F}$ M identity theft

2. Read the sample essay in the Appendix. Discuss the role and effect of the death penalty in some American states. Do you agree or disagree with the author's arguments? 


\section{The School System}

Education

is the only equalizer of

social differences.

(Rannae Hanson)

In this chapter you will learn:

- What are the basic principles of the US school system?

- How does the US school system differ from the Slovak one?

- Which are the most significant school institutions in the USA?

\section{Study and explain the following terms:}

the Old Deluder Law

national curriculum

school district

school board

K-12

tuition junior high school

high school

college

community college

bussing

\subsection{Historical Milestones in US Education}

There have been several important milestones in the history of the US public education:

The Puritan period - origins of the public schools: The first school in America (Henrico College) was founded in 1619 in Jamestown. The reasons were self-evident: the English colonists, who had a religious obligation to read the Bible daily, needed both educated ministers and literate citizens. Quakers also required all parents in Pennsylvania to teach their children reading and writing. In 1647, an important law was passed; it required that every village with 50 families provide a school and a teacher to defeat "that old deluder, Satan." Therefore the law was called The Old Deluder Law. In this period, the country's oldest and most prestigious higher education institution, Harvard University, was founded in Massachusetts (1636). Nowadays it is a member of the top-quality Ivy League universities.

The Post-War of Independence Period - the Beginnings of American Culture: After the War of Independence, the newly formed USA wanted to divide themselves from Britain not only politically, but also culturally. There were attempts to write a new, national literature celebrating American life (James Fennimore Cooper's The Last of the Mohicans is a representative piece of the period). Schools also became places where the "new American culture" (Ibid.) was perpetuated.

George Washington and Thomas Jefferson also supported the dissemination of knowledge. In the $1830 \mathrm{~s}$, there was an educational awakening and the desire to open schools, supported by taxes, to all American children. In the 1850s, the first kindergartens emerged. By the 1860 s, elementary schools had spread widely and there was a great demand for high schools. In 1862, the Morrill Act enabled the establishment of colleges and universities on public land. Even nowadays, there is at least one land-grant university in every state. There was also a tradition of educating women and men (after 
they came of age) separately: young women were educated at "dame schools"; men were prepared for universities in "military colleges."

\begin{tabular}{|c|c|c|c|}
\hline $\begin{array}{c}\text { Staring } \\
\text { age }\end{array}$ & Gradellevel & \multicolumn{2}{|c|}{ Type of school } \\
\hline $3-4$ & \begin{tabular}{|l|} 
preschool (SK equivalent \\
predprimáme vzdelávane)
\end{tabular} & \multicolumn{2}{|c|}{$\begin{array}{c}\text { mulsery school } \\
\text { (SK śstolka) }\end{array}$} \\
\hline 5 & $\begin{array}{l}\text { kindergaiten } \\
\text { (SK: predškolská výchova) }\end{array}$ & \multirow{6}{*}{$\begin{array}{c}\text { elementary school } \\
\text { (SK základna } \\
\text { škola ) }\end{array}$} & \multirow{7}{*}{$\begin{array}{l}\text { elementary } \\
\text { school }\end{array}$} \\
\hline 6 & 1st grade = prvý roc̆nik & & \\
\hline 7 & Znd grade & & \\
\hline 8 & 3rd grade & & \\
\hline 9 & 4th grade & & \\
\hline 10 & 5th grade & & \\
\hline 11 & 6th grade & \multirow{3}{*}{ midde school } & \\
\hline 12 & 7 th grade & & \multirow{2}{*}{$\begin{array}{l}\text { juinor } \\
\text { high } \\
\text { school }\end{array}$} \\
\hline 13 & 8th grade & & \\
\hline 14 & 9th grade (freshnan) & \multirow{4}{*}{\multicolumn{2}{|c|}{$\begin{array}{c}\text { high school } \\
\text { (SK: stredná škola) }\end{array}$}} \\
\hline 15 & 10th grade (sophornore) & & \\
\hline 16 & 11th grade (union) & & \\
\hline 17 & 12th grade (senior) & & \\
\hline
\end{tabular}

The Present: Nowadays, young Americans can study in the public tax-supported K-12 system (from kindergarten through grade 12; SK equivalent: základná školská dochádzka). After the 5th or 6th grade, students continue in their studies at a middle school (grades 6-8) or junior high school (grades 7-8).

As the US system differs from the Slovak one, some terms are beyond translation. These include SK: prvý stupeň základnej školy, druhý stupeň základnej školy.

At the age of 16-18 (depending on the state), students can legally stop studying and start work. However, many still take the SAT (Scholastic Aptitude Test). The SAT is not a graduation exam like the maturita, but it determines the level of school students can attend in higher education (SK: vzdelávanie tretieho stupňa), which include the following:

- technical institutes (they usually take 3 years)

- private career schools (training, for example, dental technicians; also take 3 years)

- junior colleges (e.g. Community and technical colleges; 3 years)

- colleges and universities

Technical institutes, private career schools and junior colleges are equivalents to Slovak: nadstavbové štúdium, pomaturitné štúdium. At universities, graduates study as follows: 


\begin{tabular}{|c|c|c|}
\hline $\begin{array}{c}\text { Starting } \\
\text { Age/Level }\end{array}$ & Type of Study & \multirow{11}{*}{$\begin{array}{l}\text { Higher education } \\
\text { (SK: vyśšje } \\
\text { vzdelávanie, } \\
\text { vzdelávanie } 3 . \\
\text { stupña) }\end{array}$} \\
\hline 18ffreshman & \multirow{4}{*}{$\begin{array}{l}\text { undergraduate study } \\
\text { (SK equivalent: bakalárske ștúdium ) } \\
\text { Degrees awarded: } \\
\text { BA (Bachelor of Arts) } \\
\text { BSc (Bachelor of Science) } \\
\text { B Mus (Bachelor of Music) }\end{array}$} & \\
\hline 19/sophomore & & \\
\hline 20fjunior & & \\
\hline 21/senior & & \\
\hline 22 & \multirow{2}{*}{$\begin{array}{l}\text { graduate study } \\
\text { (SK: magisterské štúdium) } \\
\text { Degrees awarded: } \\
\text { MA (Master of Arts) } \\
\text { MSc (Master of Sciences) } \\
\text { MBA (Master of Business Administration) } \\
\text { Sometimes students also take intemships (SK: } \\
\text { prax) }\end{array}$} & \\
\hline 23 & & \\
\hline 24 & \multirow{4}{*}{$\begin{array}{l}\text { doctoral study } \\
\text { (SK: postgraduálne štúdium, doktorandské } \\
\text { štúdium) } \\
\text { Degree awarded: } \\
\text { PhD (philosophiae doctor) }\end{array}$} & \\
\hline 25 & & \\
\hline 26 & & \\
\hline 27 & & \\
\hline
\end{tabular}

American schools also differ according to their funding. Students may study at:

- public schools financed by tax money

- private schools (financed by tuition). Private schools may be parochial (e.g. supported by the Catholic Church) or independent (private but non-religious);

- other types of schools, e.g. independent charter schools (financed by the state but independent in terms of teaching philosophy. Charter schools often educate children with special needs. There are also magnet schools, which focus on education in specific fields such as mathematics, sciences or the arts. They are very popular and admission is either based on entrance exams or lottery. Instead of public or private schools some parents opt for home schooling. In Slovakia, on the other hand, home schooling is not permitted. While there are vocational secondary schools in the US, there is nothing like the English NVQ (National Vocational Qualifications) or Slovak vocational apprenticeship (SK equivalent: učnovské školstvo). Students may choose between academic and vocational subjects.

\subsection{Educational Principles of US Schools}

There are four major principles of the US schools:

1. Individualism, state system of education: Unlike in Slovakia, in the USA there is no national system of education. Each state decides the financial, legal and psychological underpinning of its education. Rules and laws differ not only from state to state but also within a state from one school district to another. This tradition goes back to the revolutionary years, when each state wrote its own constitution as well as its own set of school laws. Educational individualism results in differences among various educational systems, including:

- financial localism: different amount of funding per student (SK: normatív)

- various teacher qualifications

- various coursebooks used 
- various tests: Most states have their own high school graduation exams similar to the Slovak maturita, but there are no national exams, just several standardized tests for those who wish to study at universities, e.g. GRE - Graduate Record Examination for those who wish to enter graduate schools and SAT - Scholastic Aptitude Test). The most common test for students from other countries is TOEFL - Test of English as a Foreign Language.

2. Religious liberalism: US public schools follow the First Amendment to the Constitution and its principle of the separation of church and state. They do not promote any specific type of religion but attempt to support tolerant approaches toward other denominations. In many schools, for example, they do not only celebrate Christmas but also Jewish holidays such as Hanukkah. Organised school prayer has been banned; instead they offer their students a chance to practice worship in the privacy of prayer clubs.

3. Coeducation: The US public schools broke from the previous tradition of educating boys and girls separately; they co-educate, i.e. teach both sexes the same curriculum in the same time and manner. Some private schools are still "all boys" or "all girls" institutions, but no public school may exclude any student on the basis of their sex.

4. Desegregation: Prior to 1954, US schools in some states were segregated; Afro-American students were taught at schools that (based on the Plessy v. Ferguson Supreme Court decision) were supposed to be "separate but equal" in the education they provided.

However, in 1954, the separate-but-equal principle was challenged in the Brown v. Board of Education of Topeka Supreme Court case. Brown argued that schools for African American students were underfunded, underequipped and underfurnished and did not comply with the separate-but-equal principle. In order to achieve racial integration in the US schools, school districts were established and students were "bussed" (i.e. transported by famous yellow buses) to schools according to their school district. Nowadays, a solution to the problem of disadvantaged students from certain race or income groups has been proposed in the form of affirmative action, also called positive discrimination. Traditionally marginalized groups were given more rights and advantages (e.g. lower test scorings for university admittance) to support them in their studies. However, some argue that this causes further discrimination against non-minority students. The 1978 Regents of the University of California $v$. Bakke Supreme Court decision stated that affirmative action is legal but reverse discrimination is not.

\subsection{Educational Philosophy of US Schools}

The US educational philosophy differs from the Slovak one; the reasons for this might lie in the different requirements for graduates as well as the historical sources of inspiration for US educators.

The US educational system was greatly influenced by the American philosophies of pragmatism and utilitarianism. It extensively employs a

"hands-on" approach (SK: metóda priameho kontaktu). Many primary-school classes are practically oriented. Instead of the teacher standing in front of the class (SK: metóda frontálneho výkladu), many classes are practical and involve excursions, project preparation and presentation and student teaching. For example, the secondary-school subject civics (SK: občianska náuka) is treated differently in the US schools, often referred to as "public achievement project", "citizenship education" or "community education". Instead of note-taking, students are supposed to participate in practical activities improving the life of their community (e.g. establishing a new bus stop in the street where a school is; helping the underprivileged to get access to computers or visiting the terminally ill in hospitals and easing the end of their lives). 


\section{Follow-up}

1. Discuss the advantages and disadvantages of the US school system.

2. In what way is the US school system depicted in the TV series The Simpsons? Can you remember any other films showing life at American schools?

3. Discuss the advantages and disadvantages of the American "hands-on" approach in teaching. What is gained? What is lost via teaching this way?

4. Analyse the following activity. Imagine that you are teaching a foreign language in a multicultural classroom (e.g. with seven white American students, six African American students, four Chinese students, one Indian student, one Native American, one Slovak and two Polish students).

Do you find this activity culturally acceptable (are all the cultures and nationalities represented equally or are some overrepresented and some underrepresented?)?

\section{Sample Introductory Activity: Find Somebody Who...}

Lexical aim: Teaching new vocabulary - nationalities, food, habits.

Grammatical aim: Practicing questions.

Cultural aim: Learning more about other students and their cultures.

Instructions: Ask the students in your class the following questions, write down the answers. The first one who completes all boxes with names wins.

Practice structures: Are you from ...Spain?

Do you eat ...tortillas?

Do you drive to school?

\begin{tabular}{|l|l|l|}
\hline Find somebody who: & Find somebody who: & Find somebody who: \\
Is from Czechoslovakia: & Eats hamburgers: & $\begin{array}{l}\text { Drives to school: } \\
\text { Name: }\end{array}$ \\
Name: & Name: & Eats "goulash": \\
Is from the USA: & Name: & Lives in a house: \\
Name: & Name: \\
\hline Is from China: & Eats steaks: & Has more than 4 siblings: \\
Name: & & Name: \\
\hline
\end{tabular}


End of Activity 


\section{American Art}

Just as there is no single ethnic group,

There is also no single American style.

(Jansen, R. Fiedler, E.)

In this chapter you will learn:

- What are the most significant milestones in US cultural history?

- What are the main trends, movements in US fine and performing arts?

\section{Study and explain the following terms:}

$$
\text { op art }
$$

pop art

abstract expressionism

minimalism

\section{Broadway, off-Broadway,} off-off-Broadway

little theaters

repertory theater

American culture encompasses a wide variety of arts, from visual to performing arts and from artistic to commercial art. In this chapter we will look at those arts that have been significant for the development of American culture and those that have played an important role in US cultural history.

\subsection{US Visual Arts (Painting and Sculpture)}

\subsubsection{Historical Milestones in American Visual Art}

The history of US visual (fine) art can be divided into several movements and schools:

\begin{tabular}{|c|c|c|c|}
\hline Period & $\begin{array}{c}\text { Movement/ } \\
\text { School }\end{array}$ & Characteristics & Representatives \\
\hline 17 th c. & & $\begin{array}{l}\text { - Imitation of English styles of at least } \\
\text { a century earlier; } \\
\text { - Flat portraiture }\end{array}$ & Charles Wilson Peale \\
\hline 18th c. & $\begin{array}{l}\text { The Hudson River } \\
\text { Valley School }\end{array}$ & $\begin{array}{l}\text {-Portraiture of landholders; } \\
\text {-Professional artists prevailed over the } \\
\text { semi-trained in the mid-1750s }\end{array}$ & $\begin{array}{l}\text { Benjamin West } \\
\text { John Singleton Copley }\end{array}$ \\
\hline $\begin{array}{l}\text { After } \\
1776\end{array}$ & Portraiture & $\begin{array}{l}\text {-Portraiture extremely popular } \\
\text {-Portraitists trained by Benjamin West }\end{array}$ & $\begin{array}{l}\text { Ralph Earl } \\
\text { Gilbert Stuart } \\
\text { John Trumbull (the } \\
\text { nation's history painter) }\end{array}$ \\
\hline
\end{tabular}




\begin{tabular}{|c|c|c|c|}
\hline & Romantic portraiture & & $\begin{array}{l}\text { Samuel F. B. Morse } \\
\text { (later turned his } \\
\text { attention to electric } \\
\text { telegraphy) }\end{array}$ \\
\hline & $\begin{array}{l}\text { Genre painting - } \\
\text { The First } \\
\text { Generation of } \\
\text { Hudson River } \\
\text { School }\end{array}$ & $\begin{array}{l}\text {-Recorded lives of farmers } \\
\text {-Romantic, idealized } \\
\text {-Classical style prevailing }\end{array}$ & $\begin{array}{l}\text { Thomas Cole (founder } \\
\text { of the HR school) }\end{array}$ \\
\hline & $\begin{array}{l}\text { The Second } \\
\text { Generation of } \\
\text { Hudson River } \\
\text { School }\end{array}$ & $\begin{array}{l}\text {-More realistic } \\
\text {-Use luminism - effects of light }\end{array}$ & $\begin{array}{l}\text { Frederick E. Church } \\
\text { Albert Bierstadt }\end{array}$ \\
\hline $\begin{array}{l}\text { After } \\
1865\end{array}$ & & Realism, academic style & $\begin{array}{l}\text { Winslow Homer } \\
\text { Thomas Eakins }\end{array}$ \\
\hline $\begin{array}{l}\text { Early } 20 \text { th } \\
\text { c. }\end{array}$ & $\begin{array}{l}\text { Avant-garde group: } \\
\text { "The Eight" }\end{array}$ & -Characteristic vigorous brushwork & \\
\hline \multirow[t]{3}{*}{$\begin{array}{l}\text { After } \\
1917\end{array}$} & & $\begin{array}{l}\text {-Cooperation with European artists } \\
\text { (Picasso) } \\
\text {-Abstract art }\end{array}$ & Max Weber \\
\hline & Regionalism & $\begin{array}{l}\text {-Depicting life of the American town } \\
\text { or farm }\end{array}$ & \\
\hline & Realism & $\begin{array}{l}\text {-Depicting realistically the American } \\
\text { landscape, town }\end{array}$ & Edward Hopper \\
\hline \multirow[t]{3}{*}{$\begin{array}{l}\text { After } \\
1945\end{array}$} & $\begin{array}{l}\text { Abstract } \\
\text { Expressionism }\end{array}$ & $\begin{array}{l}\text {-Reinterpretation of abstract painting } \\
\text { in terms of the strong colour of } \\
\text { Expressionism }\end{array}$ & $\begin{array}{l}\text { Jackson Pollock } \\
\text { Willem de Kooning }\end{array}$ \\
\hline & Pop Art, Op Art & $\begin{array}{l}\text {-Reaction against Abstract } \\
\text { Expressionism } \\
\text {-materializing objects of art } \\
\text { (Campbell Soup) }\end{array}$ & $\begin{array}{l}\text { Jasper Johns } \\
\text { Andy Warhol } \\
\text { Roy Lichtenstein }\end{array}$ \\
\hline & Minimalism & Minimal input, maximum meaning & Mark Rothko \\
\hline
\end{tabular}

\subsubsection{US Fine Arts in the 20th century}

In the 20th century, several schools and approaches to arts emerged that changed the previous perception of "reality", namely: 
Modernism: At the beginning of the 20th century, it was originally called the avant-garde until the word modernism prevailed. This movement identified itself as attempting to overthrow aspects of tradition or the status quo. In literature, the modernists explored new topics, such as sex and the human subconscious. Modernism encompasses many minor movements, for example surrealism and symbolism. In fine arts, the US modernists attempted to capture the modern era: they depicted modern subjects, such as famous bridges and buildings, or used modern painting techniques.

Abstract expressionism: Abstract expressionism emerged in the 1940s. It questioned previously used techniques, subjects as well as the definition of art itself. Abstract expressionists liberated many artistic conventions. Their techniques of painting included "placing outstretched raw canvas on the floor where it could be attacked from all sides by artistic and industrial materials, dripping and throwing paint, staining and brushing."

Op art: Op art is short for "Optical Art", which uses optical illusions, psychedelic motifs and various graphic and geometrical shapes to convey the idea that the senses are deceptive.

Pop art: In 1958, the term Pop Art was first used by Lawrence Alloway to describe paintings that celebrated the consumerism of the post Second World War era. Pop artists celebrated "...material consumer culture, advertising and iconography of the mass production age." Therefore, pop artists did not hesitate to depict food, clothes and pop stars and their reproductions in their paintings.

Minimalism: Minimalism emerged in the early 1960s as one of the modernist movements that served as a precursor to post-modernism. Minimalism is rooted in geometric abstraction and extreme simplicity that has a potential to capture the gist of the meaning.

Graphic experiments focus on experimenting with graphics; the artists deny the traditional subjects of fine arts (such as nature or society-related subjects) and pick various graphic objects, such as geometric shapes and newspaper clippings that transmit meanings as the central point of their paintings. Sometimes, graphic experiments are also referred to as mixed media.

Collage, assemblage, installations: Artists often use combinations of paintings and sculpture and large physical objects, such as stuffed animals, birds, and photographs to move away from all previous conventions of painting and sculpture.

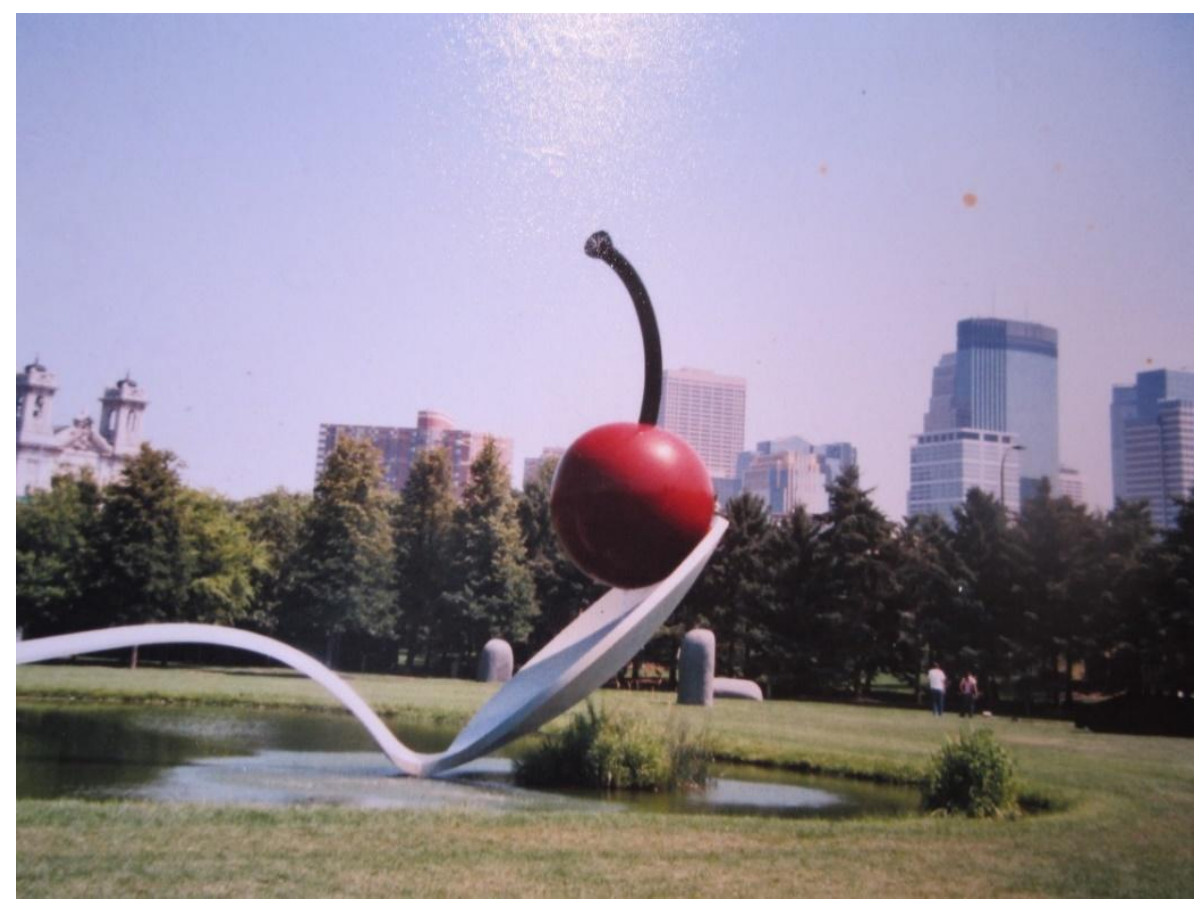

Figure 19: "Spoonbridge and Cherry" (by Claes Oldenburg and Coosje van Brugen, 1985-88); an installation in Minneapolis Sculpture Garden. Photo: Jana Javorčíková. 


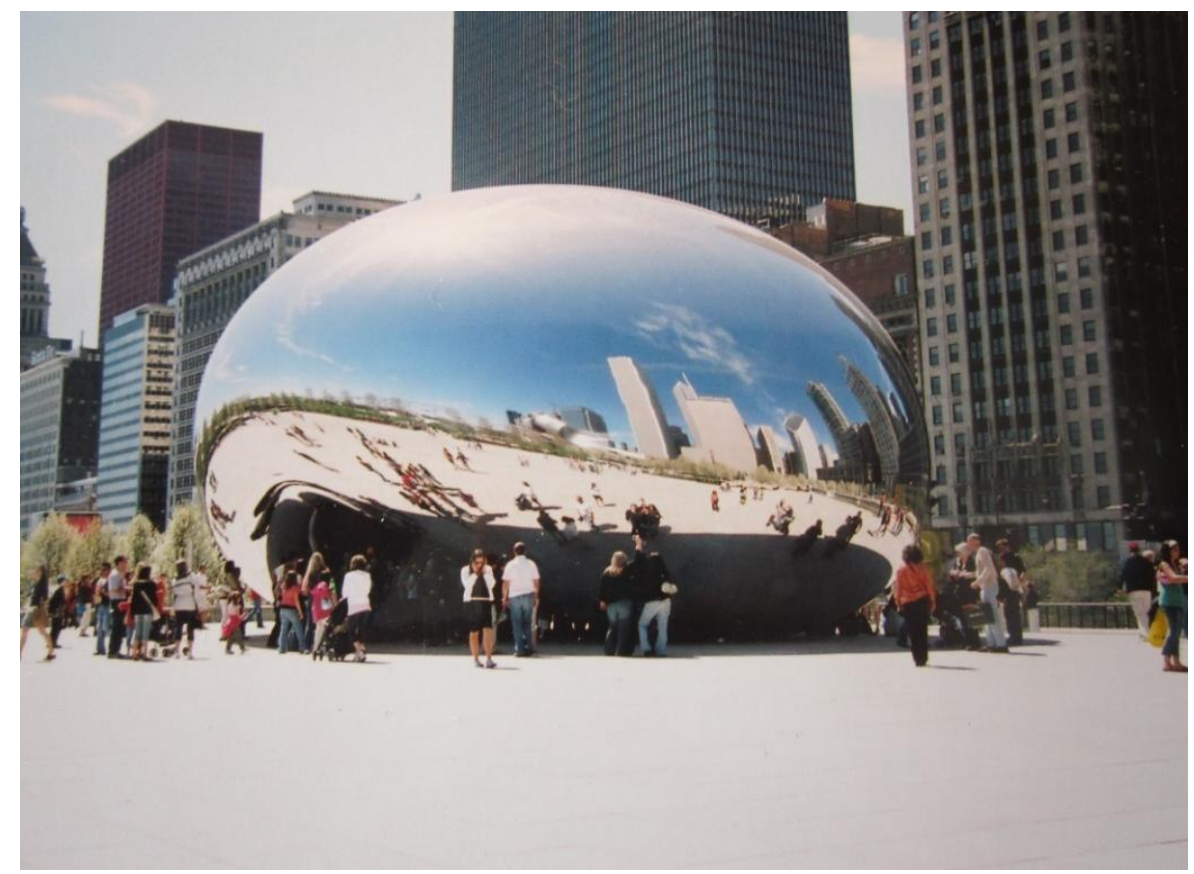

Figure 20: "Cloud Gate" (by Anish Kapoor, built in 2004-2006); an enormous stainless-steel sculpture in Millennium Park, Chicago colloquially referred to as "The Bean”. Photo: Jana Javorčíková.

\subsection{US Performing Arts - Theatre, Film, Music and Dance}

\subsubsection{US Theatre}

Broadway is the name of the only diagonal street in Manhattan, New York, which is associated with theatre. The most famous theatres are in or around Times Square (this part is also called the Great White Way because of the lights). Broadway's best years were the 1920s, when there were as many as 80 theatres, including the famous experimental theatrical group called the Provincetown Players. Many quality plays have premiered on Broadway, such as Long Day's Journey into Night, Death of a Salesman and Who's Afraid of Virginia Woolf? Nowadays, mostly musicals (such as Mamma Mia!), interactive performances (such as those of the Blue Man Group) and light comedies are to be seen on Broadway, as most spectators are tourists or those who seek light genres.

Off-Broadway (OB) theatres emerged in the 1960s as a protest and escape from the commercial Broadway. They are located in minor streets next to Broadway. They offer more experimental, intellectually stimulating plays. For example, some plays by Edward Albee premiered off Broadway.

Off-off-Broadway (OOB) is a set of even more distant theatres from Broadway, both physically and artistically. They offer extremely experimental avant-garde plays, using methods of post-modern and total theatre. Some of these methods include physical interaction with spectators during the performance, shocking sounds, flashing lights and extreme language. Off-off-Broadway stages are also unconventional, situated in lofts in the part of Manhattan called SoHo.

\subsubsection{American Film and TV}

Writing only a half-page chapter about American film and TV might sound overly ambitious; however, here are some film- and TV-related phenomena any professional researcher in American studies should know about:

Soap operas: Their name might sound strange, but they were first financed by soap-making companies. Many US soaps, such as the older ones (Dallas and Dynasty) and the more recent ones (Desperate Housewives) are now internationally broadcasted; others such as Days of Our Lives and The Young and the Restless are mostly known in the USA. 
Stand-up comedy shows and talk shows: Both are based on direct contact with the spectator. Some famous talk shows include Oprah Winfrey Show, Jerry Springer and that of stand-up comedian Ellen DeGeneres.

Reality TV: Reality TV shows are now a rather globalized phenomena that, however, has little to do with reality. Originally the medium was inspired by George Orwell's novel 1984; Big Brother was a police method of watching people perpetually, even in private, and controlling their private thoughts and actions. US reality shows include Big Brother (showing a group of people boxed in a house and monitored all the time); various contests and competitions (e.g. Donald Trump's The Apprentice, American Idol - similar to the Slovak Superstar singing contest).

TV evangelism: Also called the electronic church. Evangelicals, usually representing right-wing political standpoints, broadcast God's word through TV programmes in order to reach the widest possible audience. They believe in the ultimate power of the Bible and a direct and personal relationship with Jesus, and they actively try to convert others to their faith.

\subsubsection{American Music and Dance}

Various genres and types of music have emerged in the USA or been substantially altered from their original inspirational sources in various periods of US history. The most popular ones include:

Jazz: a kind of music born in the USA. Like the blues, jazz was influenced by the work songs and spirituals sung by African American slaves. It became popular when New Orleans street bands started to play it and famous singers started to sing it, such as singer Ella Fitzgerald, pianist and composer Duke Ellington, and trumpeter Louis Armstrong (nicknamed "Satchmo" because of his big mouth resembling a schoolboy's satchel).

Early forms of jazz were called ragtime (developed by composer Scott Joplin into a serious genre). In the 1920s, New York and Chicago became centres of jazz. The Jazz Age (the 1920s era of the rising popularity of jazz music) was named after this type of music; however, it also refers to the title of the book Tales of the Jazz Age (1922) by F. Scott Fitzgerald. The same era was also called the Roaring Twenties (SK: Burácajúce dvadsiate roky). The atmosphere of the Roaring Twenties was on one hand overly optimistic (due to the end of the war, new technologies, cars, new courageous and unbound women - a.k.a. flappers) but all these good times were tempered by the Prohibition, and there was something doomsday-like about their atmosphere.

Other types of music originating in America are:

- Country music: combining the traditional music of the US West and the South, i.e. cowboy songs and hillbilly music. The birthplace and centre of country music is Nashville, Tennessee

- Bluegrass: an Appalachian type of music combining folksong of the British Isles with that of West Africa, played on string instruments such as banjo, guitars and fiddles

- Rock-and-roll: a fast combination of jazz, blues and country originating in the 1950s; the expression rock-and-roll originally referred to sex and was thus shocking; Elvis Presley and Buddy Holly are some famous rock-and-rollers

- $\quad \mathbf{R} \& \mathbf{B}$ (rhythm and blues): a combination of blues, jazz and gospel

- Gospel: Christian religious music sung by African Americans mostly. Aretha Franklin is a famous gospel singer.

- Rap (or hip-hop): a combination of rhythmic spoken word with repetitive rhythms often based on electronics or samples. Deals with a variety of subjects related to the urban African American experience, including a more violent and thus criticized version, 1990s gangsta rap

- and many others 
Musicals: Musicals are a very typical and popular American music genre. They combine features of ballet, drama and music. Some historians trace their origins to the steamboats cruising down the Mississippi River, when passengers were entertained by a combination of comedy sketches and music. The most notable musicals are:

Porgy and Bess (1935), a musical by Ira and George Gershwin, it is also called the America's first folk opera based on jazz and blues. It was based on a novel with the same title. The main characters are Porgy (a beggar) and Bess. Perhaps its most famous song is "Summertime". Another famous piece by George Gershwin is the instrumental Rhapsody in Blue. Other famous musicals that have become "American classics" include West Side Story (by Leonard Bernstein and Stephen Sondheim; premiered on Broadway in 1957) and The Fantastics (music by Tom Jones, premiered in 1960). Popular recent musicals include, for example, A Chorus Line.

The most remarkable American dancer and the leader of the modern dance movement was Isadora Duncan (1878-1927). Later dancers and choreographers include Martha Graham, Alvin Ailey and Twyla Tharp. 


\section{Follow-up}

1. On the internet, look up the following American fine artists:

\begin{tabular}{|l|l|l|}
\hline Andy Warhol & Mark Rothko & Barnett Newmann \\
Jackson Pollock & Frank Stella & Claes Oldenburg \\
Roy Lichtenstein & Stuart Davis & Jasper Jones \\
Chuck Close & Robert Motherwell & John Martin \\
\hline
\end{tabular}

Decide who represents the following movements or trends and why:

\begin{tabular}{|l|l|}
\hline Modernism & \\
\hline Abstract Expressionism & \\
\hline Op Art & \\
\hline Pop Art & \\
\hline Minimalism & \\
\hline Graphic experiments & \\
\hline Collage & \\
\hline Assemblage & \\
\hline Installation & \\
\hline
\end{tabular}




\section{Famous Holidays, Events and People}

I'm the greatest.

(Muhammad Ali)

In this chapter you will learn:

- What holidays do the Americans celebrate and why?

- How do holidays illustrate the values and priorities of a country?

- What are some famous quotes and notable Americans?

- How has globalization affected major American holidays?

\begin{tabular}{ll} 
Study and explain the following terms: & \\
\hline floating holiday & Resurrection \\
fixed holiday & Passover \\
national, legal, religious holiday & Hanukkah \\
patriotic holiday & Yuan Tan
\end{tabular}

\subsection{Famous American Holidays}

In the USA, various types of holidays are celebrated. These are:

- National holidays (e.g. Independence Day, a.k.a. the Fourth of July) are recognized by the federal government. Most institutions are closed on these holidays.

- Legal or official holidays (e.g. Labor Day). These are recognized in most states. On that day some schools celebrate these holidays instead of regular teaching.

- Religious holidays: Most businesses and public institutions (such as schools) close on Christmas. Some schools also close for other religious holidays. This is, however, controversial, due to the supposed separation of church and state.

- Unofficial holidays (e.g. April Fool's Day). No institutions are obliged to respect these.

Some of these holidays are fixed (they always fall on the same date, e.g. July 4th), and others are floating (SK: pohyblivé sviatky; they for example fall on the last Monday in May). US holidays can be divided according to their nature into:

- major holidays, e.g. patriotic and religious holidays;

- minor holidays, e.g. family and friend-focused holidays.

\subsubsection{Major holidays: religious holidays}

Major and nowadays rather globalised holidays such as Christmas, Easter and New Year's Eve differ from their European equivalents. Christmas, for example is celebrated in most American Christian households by: 
- exchanging gifts

- receiving gifts from Santa Claus

- hanging a stocking near the chimney

- decorating the home with a Christmas tree and other evergreen decorations (branches and wreaths of fir, spruce and poinsettia)

- singing Christmas carols

- sending Christmas cards (often called Season's Greetings)

Of course not all American households are Christian. However, many now express appreciation for all religions and thus celebrate multiple religious traditions, such as Christmas and Hanukkah, the Jewish Festival of Lights celebrated in December. Hanukkah commemorates religious freedom. Tiersky writes,

"In 168 BC, the Syrian King Antiochus conquered Judea and tried to force the Jews to worship pagan gods. Three years later, a small band of Jews led by Judas Maccabaeus defeated the powerful Syrian armies. When the Jews recaptured Jerusalem and rededicated the Holy Temple, they relit the eternal lamp. One day's supply of oil - all that was left - burned for eight days, until fresh oil was available. In memory of this miracle, Jews celebrate Hanukkah for eight days and light candles in a special candleholder called a menorah. In addition to the candle used to light the others, Jews light one candle on the first day of Hanukkah, two on the second day, and so on until the eight day, when candles are burning in all nine branches of the menorah."

New Year's Eve is celebrated in a similar fashion to Europe: with noisy parties and fireworks. However, there are typical New Year's Day festivals: the Mummer's Parade (which takes place in Philadelphia, where people dress in lavish costumes as clowns, musicians, dancers and join the parade) and the Tournament of Roses (in Pasadena, California, where elaborate floats displaying roses and other flowers can be seen).

Ethnicities such as Chinese Americans and Jewish Americans celebrate their own special holidays. The fifteen-day Chinese New Year starts with Yuan Tan (a private family holiday) and concludes with the Festival of Lanterns.

Jewish New Year is called Rosh Hashanah (meaning "head of the year"). It is a solemn holiday when devoted Jews make vows to be a better person in the next year.

Easter also differs from the European tradition. The Catholic version of Easter includes a chain of holidays:

- Shrovetide (three or four days preceding Lent; SK: koniec fašiangov);

- Mardi Gras (French for Fat Tuesday); it is celebrated by parades, especially in New Orleans;

- Lent (SK: Pôst; begins with Ash Wednesday, SK: Popolcová streda);

- Palm Sunday (the beginning of Holy Week);

- Maundy Thursday (Holy Thursday);

- Good Friday (SK: Vel'ký piatok);

- Easter Sunday (SK: Vel'konočná nedel’a). 
The Jewish equivalent of Easter is called Passover (SK: Pesah). It commemorates the liberation of the Hebrews from slavery in ancient Egypt. It is celebrated by a special dinner (including symbolic foods such as eggs, lamb, matzoh and wine) and prayers.

Other religion-based holidays include:

\begin{tabular}{|l|l|l|}
\hline Name of the Holiday & Date & Celebrates: \\
\hline St. Patrick's Day & March 17 & $\begin{array}{l}\text {-the national day of Ireland, adopted } \\
\text { by the Americans. It honours } \\
\text { Ireland's patron saint, who brought } \\
\text { Christianity to the pagans. It is } \\
\text { celebrated with parades in Boston, } \\
\text { Chicago and New York. }\end{array}$ \\
\hline Halloween & October 31 & $\begin{array}{l}\text {-Pagan rituals, even though the name } \\
\text { (All Hallows Eve) comes from a } \\
\text { Christian festival. Nowadays it is a } \\
\text { holiday for children who do various } \\
\text { pranks (write on doors, soap } \\
\text { windows) and ask for treats, saying: } \\
\text { "Trick or treat" (SK: maškrtu alebo } \\
\text { nezbedu) or "Money or eats!" } \\
\text { The symbol of Halloween is a lantern } \\
\text { carved out of a pumpkin called a Jack- } \\
\text { o'-lantern (SK: Svetlonos). }\end{array}$ \\
\hline
\end{tabular}

\subsubsection{Major holidays: political and patriotic holidays}

These are also some American patriotic holidays, known from movies and news:

\begin{tabular}{|l|l|l|}
\hline Name of the Holiday & Date & Celebrates: \\
\hline $\begin{array}{l}\text { Independence Day } \\
\text { (a.k.a. the Fourth of } \\
\text { July) }\end{array}$ & $\begin{array}{l}\text { Official US } \\
\text { holiday } \\
\text { July 4 (first } \\
\text { celebrated in } \\
1776)\end{array}$ & $\begin{array}{l}\text { ine nation's independence } \\
\text { from Britain. On that day, the } \\
\text { Continental Congress gave its } \\
\text { approval of the Declaration of } \\
\text { Independence. It is celebrated } \\
\text { with fireworks, barbecues and } \\
\text { speeches. }\end{array}$ \\
$\begin{array}{l}\text { Columbus Day } \\
\text { (also called Discovery } \\
\text { Day) }\end{array}$ & $\begin{array}{l}\text { Second Monday } \\
\text { in October }\end{array}$ & $\begin{array}{l}\text {-Christopher } \\
\text { popularly considered to be the } \\
\text { first European explorer of } \\
\text { America. Some find this }\end{array}$ \\
\hline
\end{tabular}




\begin{tabular}{|l|l|l|}
\hline & $\begin{array}{l}\text { holiday discriminatory to the } \\
\text { original inhabitants and } \\
\text { celebrate Indigenous People's } \\
\text { Day (SK: Deñ pôvodných } \\
\text { obyvatel'ov) instead. }\end{array}$ \\
\hline Thanksgiving & $\begin{array}{l}\text { Fourth Thursday } \\
\text { in November }\end{array}$ & $\begin{array}{l}\text {-the hardships endured by the } \\
\text { early European colonisers of } \\
\text { America and the help they } \\
\text { received from the Native } \\
\text { Americans. It is celebrated } \\
\text { with a traditional dinner } \\
\text { (including stuffed turkey, } \\
\text { sweet potatoes, yams, jellied } \\
\text { cranberries, etc.). }\end{array}$ \\
\hline
\end{tabular}

Another series of quite well-known patriotic holidays is devoted to notable politicians and famous individuals in American history. Some of these holidays are:

\begin{tabular}{|l|l|l|}
\hline Name of the Holiday & Date & Celebrates: \\
\hline $\begin{array}{l}\text { Martin Luther King, } \\
\text { Jr. Day }\end{array}$ & $\begin{array}{l}\text { Official US } \\
\text { holiday: } \\
\text { third Monday in } \\
\text { January (on or } \\
\text { near January 15, } \\
\text { King's birthday) }\end{array}$ & $\begin{array}{l}\text { American leader of the US } \\
\text { civil rights movement. }\end{array}$ \\
\hline Presidents' Day & $\begin{array}{l}\text { Legal holiday in } \\
\text { most states: } \\
\text { Third Monday in } \\
\text { February }\end{array}$ & $\begin{array}{l}\text {-the birthday of George } \\
\text { Washington, the "father of } \\
\text { chief of the revolutionary } \\
\text { forces and the first American } \\
\text { president. }\end{array}$ \\
\hline Lincoln's Birthday & $\begin{array}{l}\text { Legal holiday in } \\
\text { most states: } \\
\text { First Monday in } \\
\text { February } \\
\text { February 12 or }\end{array}$ & $\begin{array}{l}\text {-the US president who issued } \\
\text { the Emancipation } \\
\text { Proclamation in 1863. }\end{array}$ \\
\hline
\end{tabular}

\subsubsection{Minor holidays: political and historical holidays}

Minor holidays which are perhaps less well-known in Europe are: 


\begin{tabular}{|l|l|l|}
\hline Memorial Day & Last Monday in May & -Americans killed in wars. \\
\hline Flag Day & June 14 & $\begin{array}{l}\text {-the birthday of the US "Stars and } \\
\text { Stripes" flag, originally with six- } \\
\text { point stars (made by Betsy Ross). }\end{array}$ \\
\hline Labor Day & $\begin{array}{l}\text { First Monday } \\
\text { September }\end{array}$ & $\begin{array}{l}\text { in } \\
\text {-the efforts of the labour unions } \\
\text { that accomplished the 37-to-42- } \\
\text { hour work week }\end{array}$ \\
\hline Veterans Day & November 11 & $\begin{array}{l}\text {-all men and women who have } \\
\text { served in the armed forces. People } \\
\text { hang flags outside their homes, } \\
\text { parades occur in many cities. }\end{array}$ \\
\hline
\end{tabular}

Another type of American festivity is state fairs. One of the most notable ones is the Minnesota State Fair, similar to the Slovak fair known as Agrokomplex.

\subsubsection{Minor holidays: unofficial and family holidays}

There is also a set of more private and family-focused holidays. These are:

\begin{tabular}{|l|l|l|}
\hline Name of the Holiday & Date & Celebrates: \\
\hline April Fool's Day & April 1 & $\begin{array}{l}\text {-a day of practical jokes. } \\
\text { Some typical pranks } \\
\text { include: calling the zoo and } \\
\text { asking to speak to Mr Lion; } \\
\text { putting salt in the sugar } \\
\text { bowl and setting the clocks } \\
\text { back an hour. }\end{array}$ \\
\hline Valentine's Day & February 14 & $\begin{array}{l}\text {-love between partners or } \\
\text { mothers and children }\end{array}$ \\
\hline Mother's Day & National holiday: & $\begin{array}{l}\text {-love and care of mothers. } \\
\text { Mothers usually receive } \\
\text { flowers and hand-made } \\
\text { cards from their spouses } \\
\text { and children. }\end{array}$ \\
\hline Father's Day 8 & $\begin{array}{l}\text { June Sunday in } \\
\text { third }\end{array}$ & $\begin{array}{l}\text {-fatherly love. Fathers } \\
\text { gifts. greeting cards and }\end{array}$ \\
\hline
\end{tabular}




\subsection{Famous People in US History}

In the previous chapters, we have mentioned many famous Americans who have greatly contributed to the development of the USA. However, due to the scope and size of this coursebook, many more remained unmentioned. In this chapter, we would like to mention the most notable Americans; however, such an attempt might be overly ambitious given the number of writers, inventors, scientists and other renowned persons who have become internationally famous. Therefore, we have decided to mention only those who are frequently referred to in the press and media and we feel should be recognized by professional Americanists or those who have some personal or professional ties to the region of former Czechoslovakia.

Interestingly, there is a correlation between famous people and regions in the USA. Perhaps because of its high number of literate and educated people, the Northeast was taken for centuries as the centre of education and politics. Many politicians, inventors and also notable writers were born in the Northeast. Some of these are:

\section{Notable Americans of the Northeast}

\section{Famous politicians of the Northeast:}

\section{ABRAHAM LINCOLN (1809-1865)}

Lincoln, nicknamed "Honest Abe", was born in a log cabin to poor and uneducated parents and received very little schooling. He was elected the 16th President in 1860 and reelected in 1864 as the first successful Republican presidential candidate. In 1863 he issued the Emancipation Proclamation, declaring all slaves in the rebellious states to be free. Lincoln became famous for saying, "A house divided against itself cannot stand. I believe this government cannot endure permanently half slave and half free." Parts of his speeches have become famous, for example, his Gettysburg Address, where he said: "...that this nation, under God, shall have a new birth of freedom, and that the government of the people, by the people, for the people shall not perish from the earth." In 1865, Lincoln was assassinated at Ford's Theatre in Washington).

Interesting footnote: Lincoln became famous for his rhetorical abilities. In one of his speeches he said, "Let us have faith that right makes might; and in that faith let us, to the end, dare to do our duty as we understand it."

\section{BENJAMIN FRANKLIN (1607-1690)}

Franklin was a writer, inventor (he invented the lightning rod as well as a special "Franklin" stove), political leader and printer who was also one of the American "Founding Fathers." He helped to write the Declaration of Independence and the Constitution. As a writer, he published his Autobiography, in which he perpetuated the idea of self-improvement. He also became tremendously famous for his collection of wit and wisdom, an almanac called Poor Richard's Almanack.

Interesting footnote: Franklin's Autobiography was criticized by some Puritans who believed that a man cannot achieve perfection; it is given only to God. Therefore Franklin had to add one more virtue to his list: piety. 


\section{JOHN FITZGERALD KENNEDY (1917-1963)}

Kennedy was the 35th US President (1961-1963). He was the country's youngest and the first Roman -Catholic US President. His greatest presidential success was dealing with the Cuban missile crisis, which was, however, precipitated by his worst failure - the Bay of Pigs incident. He is also associated with the phrase "New Frontier"; he said that America in 1960 was at the "edge of a new frontier" in technological advances, space and scientific exploration and the improvement of general welfare.

Interesting footnote: One of his oft-quoted sayings is: "And so, my dear fellow Americans: ask not what your country can do for you - ask what you can do for your country."

\section{FRANKLIN DELANO ROOSEVELT (1882-1945)}

Roosevelt, also known as FDR, was the only US president to be elected four times. As President, he put forward the New Deal policy (SK: politika Nového údelu), which helped to overcome the effects of the Great Depression.

Interesting footnote: FDR's famous words in his inaugural address of 1933: "The only thing we have to fear is fear itself."

\section{Famous writers and literary movements of the North:}

$$
\text { THE ROMANTICISTS (1800s-1830s) }
$$

American Romanticism was, just like its European predecessor, inspired by the French Revolution in 1789. In America, Romanticism coincided with the early national period when the new independent USA tried to separate from Britain not only politically but also artistically. American Romantic novels include James Fenimore Cooper's The Last of the Mohicans, the most famous instalment of the pentalogy Leatherstocking Tales, and Herman Melville's Moby-Dick. The best-known American Romantic poet was Edgar Allan Poe.

\section{EDGAR ALLAN POE (1809-1849)}

Poe was a prolific writer of both scary, Gothic tales (e.g. "The Pit and the Pendulum", 1843), the first detective stories (he actually invented the model of a superdetective and not-so-smart companion, later adopted by Sir Arthur Conan Doyle in his Sherlock Holmes series) and aesthetically pleasing yet morbid poems such as "The Raven" (1845) and "Annabel Lee" (1849), usually depicting an idealized beauty of a dead beauty.

Interesting footnote: Poe's poetry greatly inspired many present-day rock bands, heavy metal bands and musicians such as the controversial Australian singer-songwriter Nick Cave.

\section{THE TRANSCENDENTALISTS (the 1830s)}

The Romantic movement of the 1830s inspired the first truly "American" literary movement - the Transcendentalists. Inspired by Eastern philosophies and religions, they believed they could "transcend" this world and experience a spiritual rebirth. Nowadays, they are seen as proto- 
environmentalists. Notable Transcendentalists included Ralph Waldo Emerson, Henry David Thoreau and later Walt Whitman.

Interesting footnote: Thoreau believed in Transcendentalism so much that he actually spent two years in a log cabin (SK: zrub) in the woods next to Walden Pond in Concord, Massachusetts. This area is surprisingly similar to the surroundings of the Slovak town of Banská Štiavnica. Thoreau wrote about this experience his well-known memoir Walden.

\section{EUGENE GLADSTONE O’NEILL (1888-1953)}

O'Neill was the first American Nobel-Prize-winning dramatist. In his plays, he attempted to grasp the very nature of the American people and raise awareness of the tragic aspects of American life, underlying the fundamental American belief in success. He noticed that immigration, uprootedness and the harsh Puritan past are as apt tragic stimuli as those in the dramas of classical Greek playwrights Aeschylus and Sophocles. Among his most famous plays are: Mourning Becomes Electra (1931) and Long Day's Journey into Night (1941).

Interesting footnote: O'Neill's work was first premiered in Slovakia in 1934. The theatre in Martin attempted to put on one of his experimental and war-related plays, In the Zone, to prove they were capable of staging the work of an international author.

\section{JOSEPH HELLER (1923-1999)}

Heller was a New-York-born satirical novelist and playwright. His most famous novel, about the absurdity of the Second World War, is Catch-22 (SK: Hlava 22).

Interesting footnote: "There was only one catch and that was Catch-22, which specified that a concern for one's own safety in the face of dangers that were real and immediate was the process of a rational mind... Orr would be crazy to fly more missions and sane if he didn't, but if he was sane he had to fly them. If he flew them he was crazy and didn't have to; but if he didn't want to he was sane and had to." (Catch-22).

\section{J. D. (JEROME DAVID) SALINGER (1919-2010)}

Salinger is another New-York-born short-story writer and novelist. He became famous for his 1951 novel The Catcher in the Rye, portraying a rebelling adolescent who stood against his "phoney" parents and the middle-class values they symbolized.

Interesting footnote: Salinger was an extremely private man who tried to avoid any public contact.

\section{Famous explorers of the North:}

\section{DANIEL BOONE (1734-1820)}

He was a legendary American frontiersman who crossed the Appalachian Mountains through the Cumberland Gap, fought with Indians and survived captivity. He inspired the character of Natty Bumpo in James Fenimore Cooper's romantic novel The Last of the Mohicans. 


\section{Famous politicians and activists of the South:}

\section{GEORGE WASHINGTON (1732-1799)}

Washington was also called "The Father of the Country." He lived at his plantation, Mt. Vernon as a gentleman farmer. During the War of Independence, he was appointed by the Continental Congress commander-in-chief (SK: vrchný velitel ozbrojených sil). He is said to have been a very compassionate leader who never received any salary for his job. Instead, he often used his own money to buy clothing for his men or to aid their families. After the end of the war, he was elected as the first President of the USA. He took office in 1789 and was re-elected in 1792. To the Americans, Washington symbolizes dignity, statesmanship and honesty.

Interesting footnote: the famous "Cherry tree story":

According to Tiersky, "When Washington was about six years old, his father gave him a hatchet. One day, he tried the edge of his hatchet on his father's favourite cherry tree and did enough damage to kill the tree. Next morning, his father noticed the damage and ran into the house shouting, 'George, do you know who killed that beautiful little cherry tree yonder in the garden?' George's famous reply was, 'I can't tell a lie, Pa, you know I can't tell a lie. I did cut it with my hatchet.' [SK: Nemôžem klamat', urobil som to sekerkou.]

\section{THOMAS JEFFERSON (1743-1826)}

Jefferson was the third US President (1801-1803). He is also recognized as one of the Founding Fathers. He wrote the text of the Declaration of Independence. As president, he supported the Louisiana Purchase and the Lewis and Clark Expedition.

Interesting footnote: Jefferson opposed slavery; yet he owned slaves. He had an intimate relationship with one of the slaves - that was socially perfectly acceptable. Paradoxically, had he given her freedom, any social or personal relationships between a white man and woman of colour would not have been socially palatable.

\section{MARTIN LUTHER KING (1929-1968)}

King was originally born Michael King; however, his father later changed his name to honour the German reformer, Martin Luther. King, an Afro-American Baptist minister and a Nobel Prize winner (1964), was the most important leader of the US Civil Rights Movement. He led several peaceful campaigns against segregation in the southern states. These peaceful protests became famous as civil disobedience (SK: občianska neposlušnost'). Like Gandhi, King initiated sit-ins (SK: blokujúci/sedací štrajk) during which people of colour peacefully sat in whites-only public places such as restaurants and libraries. King was assassinated in 1968 in Memphis, Tennessee.

Interesting footnote: In 1963 King led about 250,000 people to Washington where his most influential speech at Lincoln Memorial became internationally famous: "I have a dream that one day this nation will rise up and live out the true meaning of its creed. We hold these truths to be selfevident: That all men are created equal." 
She is also called "the first lady of the American Civil Rights Movement." She rejected the segregation of buses when she refused to vacate a seat in the white section and move to the "colored" section on a bus. She was imprisoned on December 1 and this day is now celebrated in many states as "Rosa Parks Day."

Interesting footnote: Rosa Parks was not the first to protest bus segregation; however, she served as the best symbol of racial segregation in public transport.

Famous writers of the South:

MARK TWAIN (1835-1910)

Twain was the leading US humourist and writer of local colour (SK: lokálny kolorit). His novels include The Adventures of Tom Sawyer and Adventures of Huckleberry Finn, the latter of which was often mistakenly criticised for advancing racism (African American slave Jim is depicted as plain, unskilled and speaking with thick vernacular dialect). His other novels include The Prince and The Pauper and Life on the Mississippi. In Slovakia, he was critically analysed by many Slovak scholars.

Interesting footnote: Twain's real name was Samuel Langhorne Clemens. He picked his pseudonym when he was working on a Mississippi steamboat; the depth of water was reported as "mark one mark twain - mark three", and so on. Twain was one of the US authors who were very popular in the East-Bloc countries.

\section{Notable Americans of the Midwest}

\section{Famous writers:}

\section{ERNEST HEMINGWAY (1891-1961)}

This Nobel Prize winner, veteran of the First World War and the Spanish Civil War, war correspondent and writer became famous for his short stories and novels such as The Sun Also Rises, Farewell to Arms, To Whom the Bell Tolls and many others. Hemingway, Ezra Pound and Gertrude Stein are representatives of the Lost Generation (SK: Stratená generácia) - a generation who physically lost their youth or life in the war, or, metaphorically, a generation who was "lost" - lost ideals and illusions about the world. He committed suicide in 1961. Hemingway was a close friend to many expatriates, artists who gave up life in the USA and decided to live in Paris, including Stein and Pound.

Interesting footnote: Hemingway's style, now often criticized for being "too masculine", is called the "iceberg method" (SK: l'adovcová metóda): he tried to do without any enhancements of language such as excessive adjectives, metaphors and other linguistic ornaments. A text, according to Hemingway, is the tip of an iceberg; the meaning is hidden under the water. Due to his critical tone towards capitalism, he was very popular in the former East-Bloc countries. 
Kesey was born in Colorado. He became famous for his novel One Flew over the Cuckoo's Nest (1962), which has been interpreted as a metaphorical critique of totalitarianism.

Interesting footnote: Kesey was a professional wrestler; some parts of One Flew over the Cuckoo's Nest are very autobiographical. The novel was filmed by Czechoslovak emigrant Miloš Forman in 1975 and, therefore it could not be publicly distributed in Czechoslovakia during the Soviet invasion period.

\section{Notable Americans of the West}

\section{Famous writers:}

\section{JACK LONDON (1876-1916)}

London was an American writer, a representative of an extreme form of realism called Naturalism, a popular author of adventure novels and short stories. Many of his novels are autobiographical; he was a sailor and a gold prospector in the Klondike, Canada. His internationally famous novels are The Call of the Wild (1903), Sea Wolf and White Fang (1906). Another artist who depicted the Klondike Gold Rush (1897), though from a comic point of view, was Charlie Chaplin in his film The Gold Rush (1925).

Interesting footnote: Jack London sympathized with socialism, and his novel Valley of the Moon depicts the American crisis, strikes and is openly critical of the US form of capitalism. It was therefore translated in many East-Bloc countries including former Czechoslovakia.

\section{JOHN STEINBECK (1902-1968)}

Steinbeck was another author from the American West, who in 1962 received the Nobel Prize for literature. Among his novels are Of Mice and Men (1937), The Grapes of Wrath (1945) and East of Eden. He often wrote about poor farmers in California, the Oklahoma Dust Bowl and the massive migration of the unskilled labour force to the west.

Interesting footnote: Like Jack London, because of his criticism of US society, Steinbeck was well accepted and widely translated in former Czechoslovakia.

\section{THE BEAT GENERATION}

The Beatniks were a group of young people (mostly writers and artists) centred in San Francisco who diverged from the middle-class values of their parents as well as from the politics that started the wars in Korea and Vietnam. They tried to find a different style of living: explored Eastern philosophy, unbound lifestyles and drugs (Benzedrine, LSD and marijuana). They were also inspired by Walt Whitman (1819-1892), a controversial American poet and perpetuator of personal and social freedom, who published the famous poetry collection Leaves of Grass (1865). Jack Kerouac and Allen Ginsberg were among the best-known Beat Generation writers. Some of their ideas were followed by the hippies. One famous hippie gathering was the Woodstock rock festival in 1969. 
Interesting footnote: Jack Kerouac wrote in the fashion of so-called "spontaneous prose"; he wrote without any preparation, off the top of his head and usually on any piece of paper he could find. His $O n$ the Road is written on a single roll of paper; however, some literary scholars have challenged this legend and claim that Kerouac closely revised his texts. The free, unbound lifestyles of the beatniks and hippies were quite popular among the Czechoslovak youth of the time and celebrated in many folk songs. 


\section{Follow-up}

1. Complete:
a) The first American flag was made by:
b) On Memorial Day people go to:
c) Memorial Day now officially honours:
d) The meats associated with Easter are:
e) Which holiday is associated with a shamrock?

2. Discuss: How would you celebrate various holidays in a multicultural classroom?

3. Read the following and discuss cultural differences between an invitation for dinner to a Slovak household vs. an American one:

When invited to an American's home for dinner, it's polite for guests to ask, "What (food) can I bring?" The host may suggest something or say that it's not necessary to bring anything.

At the very beginning of the meal, each person puts his napkin in his lap. Sometimes, in Christian households the guest may be asked to say grace (i.e. to hold hands with the other people and say a prayer). In formal situations, some people use only one hand to eat (except for cutting meat) and leave the other in their lap during the meal.

At the end of the meal it's polite to offer to help wash the dishes. The host may either happily accept, or say that it's not necessary.

Generally, Americans don't have any greetings or wishes to tell each other at the beginning of the meal; however, in some restaurants the servers may say, "Enjoy your meal"or, in formal contexts "Bon appétit!" and in informal ones "Dig in!".

4. With the use of the internet or a dictionary of culture, try to specify the origin of the following foods/dishes/drinks and the occasion when Americans eat them:

\begin{tabular}{|l|l|}
\hline - fortune cookie & - potato chips \\
- dim sum & - BBQ \\
- donut & - soda \\
\hline
\end{tabular}




\section{Food and Agriculture (by Michael E. Dove)}

Food is much more than simply nourishment.

It embodies a complex web of relationships. It is a huge part of the context in which we exist.

(Sandor Katz)

In this chapter you will learn:

- What are "New World crops" and how are they significant?

- What distinguishes Americans' eating habits?

- How do foodways influence other aspects of US culture?

\begin{tabular}{|c|c|}
\hline \multicolumn{2}{|c|}{ Study and explain the following terms: } \\
\hline New World crops & foodie \\
\hline corn & foodways \\
\hline staple & breakfast \\
\hline selective breeding & lunch \\
\hline soybeans & dinner \\
\hline TV dinner & cafeteria \\
\hline convenience & diner \\
\hline
\end{tabular}

\subsection{What Americans (among others) eat: New World crops}

How have Native Americans influenced your life? If you don't live in a teepee or a wigwam, you might find yourself searching in vain for the answer. Yet Native Americans have actually made enormous contributions to the way people everywhere on the planet live, and more specifically, eat and Slovakia is no exception.

Imagine some of your favorite foods. Now imagine them without corn, peanuts, tomatoes, beans, pineapple, peppers (including chilies), allspice, sunflower oil, avocado, squash (including pumpkins and zucchini), vanilla, chocolate and potatoes. That means no ketchup, nothing spicy, no halušky and no Horalky. Is there much left?

That was the state of Slovak cuisine before 1492, since all the foods listed above are New World crops, i.e. crops that originated in the Americas. In fact, 1492 is quite early; most of these crops, such as peppers, didn't actually catch on in Central Europe till later. Before that, Slovaks obviously must have eaten something, but it was very different from what they eat now.

\subsubsection{Corn}


As globally influential as all these crops are, none plays a greater role than corn, and nowhere is corn more important than in the United States.

The significance of corn is apparent even in the word itself. Elsewhere in the English-speaking world, corn is called "maize", and the word "corn" itself has a more general meaning: "any cereal...esp. the chief crop of a region: wheat, oats, or (in the US and Australia) maize." Here there is an interesting parallel with the Slovak word žito, which can also refer to different grains depending on the region in which it is used. Judging by this definition, it is clear that maize has been "the chief crop" of the United States long enough to earn the name "corn".

But corn's significance to the US goes beyond being merely a staple, i.e. a chief food crop - more on that later.

First of all, a bit on corn's origins. Corn, like all New World crops, is a Native American invention. I use the term "invention" because it is not a pure product of nature - corn was crafted through human efforts and ingenuity by means of a process called selective breeding. In Figure 21, the plant on the left is teosinte, corn's natural ancestor - this is what corn looked like before Native Americans domesticated it. Teosinte, like all other cereals, is a kind of grass, and so it predictably resembles other cereal grasses like wheat, rye and barley. But as early as 10,000 years ago, people in what is now Mexico began cultivating and gradually domesticating it, reusing seeds only from those plants that displayed the qualities they sought. The primitive corn in the center of Figure 21 shows that a high number of kernels, and thus the amount of food produced by the grass, was a quality farmers had focused on encouraging.

The sheer caloric density of corn compared to other cereals supported dense populations, laying the foundation for urban Native American civilizations like the Mississippians and the Anasazi in North America, the Incas in South America, and in Mesoamerica the Maya and the ill-fated Aztecs. By the time the Spanish conquistador Cortés arrived in 1519, the Aztec capital of Tenochtitlan (now Mexico City) was one of the world's largest and most technologically advanced cities, and corn looked much like it does today (Figure 21, on the right).

While the Aztec Empire may have ended then and there (conquered as it was by Cortés), for corn it was only the beginning. Today corn is the world's top staple crop by yield. And nowhere is it more important than in the United States.

Even today, the Maya sometimes refer to themselves as "the corn people", but judging by how much we grow and eat, and even the chemical composition of our own bodies, it is we in the US who are the true corn people. The US produces and consumes more corn than any other country, both in total and per capita. You wouldn't necessarily know it by looking at what we eat, however; to see the corn hidden in our food, you have to consult the ingredients list, or delve even deeper - to what our livestock, i.e. our chickens, cows and pigs, eat. The US's vast crop of corn is now used to produce an equally vast range of products from oil and margarine to sweeteners and thickeners. But the greatest proportion of corn is used not to feed people, but animals. It is worth noting, however, that another use of corn is swiftly catching up: making ethanol fuel. 


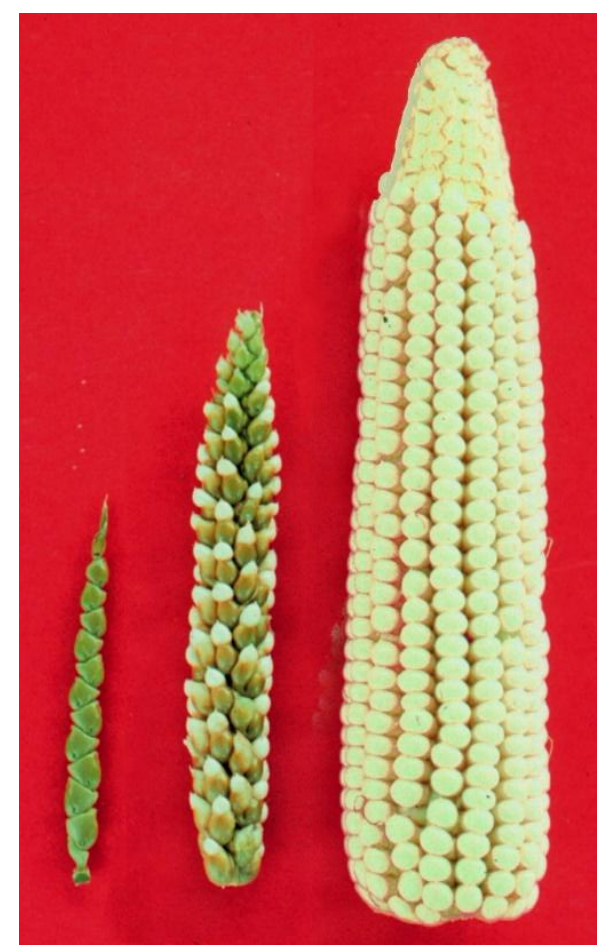

Figure 21: The development of teosinte into corn

\subsubsection{Selective breeding (continued)}

Incidentally, the process of selective breeding that produced corn is by no means exclusive to Native Americans; almost all food crops (and food animals) have been developed in this way. In Figure 2, see how the Mediterranean plant wild mustard (Brassica oleracea) has been bred, by humans, into many different modern vegetables with a range of uses, flavors, and qualities.

One vegetable you might not recognize is kale. Though its name sounds like the Slovak word kel (English: savoy cabbage), it in fact belongs to a group of vegetables known in English as "greens" essentially, the large edible leaves of any number of plants, usually requiring cooking (unlike salad greens like lettuce). One example popular in nearby Austria is chard (mangold). Despite their worldwide popularity, Slovak cuisine seems to lack this type of vegetable (with the rather unpopular exception of creamed spinach). According to the ethnobotanical literature, it seems that wild greens lost their popularity in Slovakia due to their association with wartime famine, and this stigma may have been transferred to domesticated greens as well. 


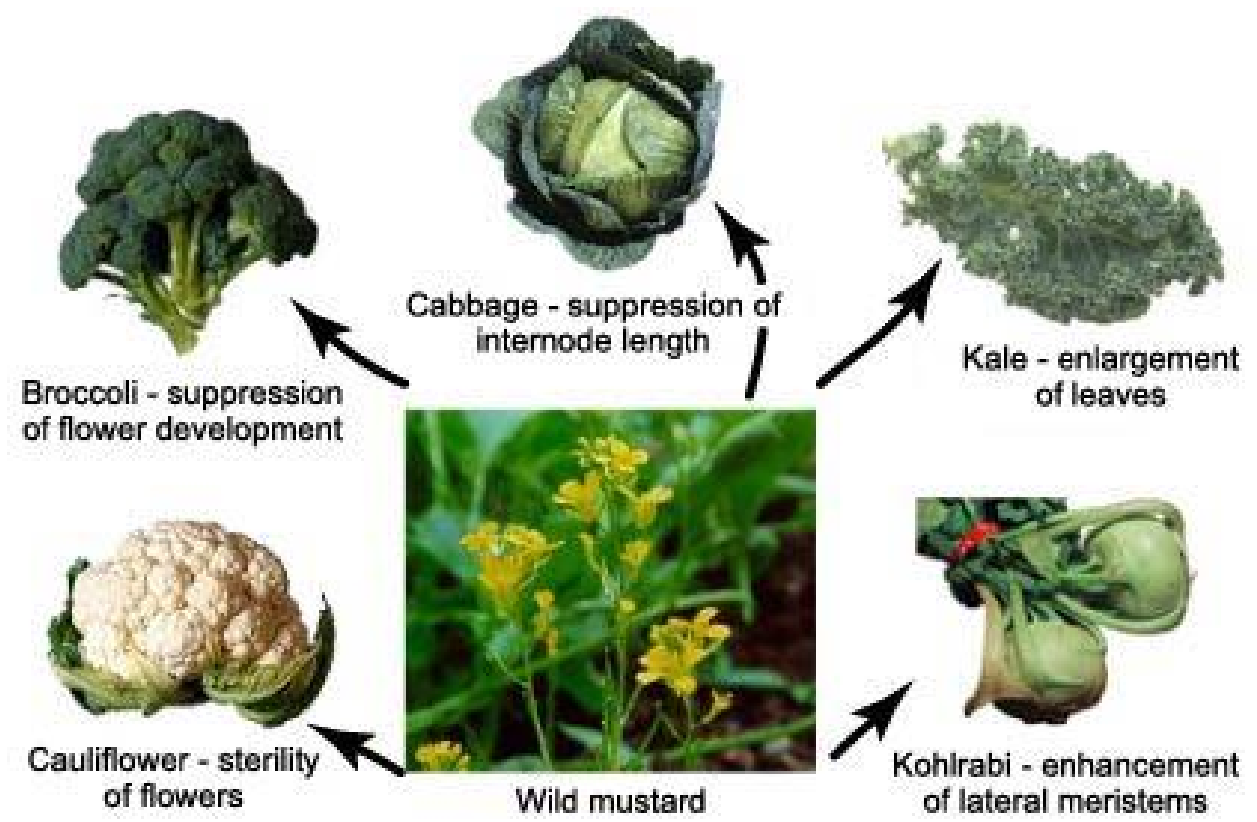

Figure 22: The artificial selection of Brassica oleracea (“Artificial selection." Understanding Evolution. University of California Museum of Paleontology. 23 August 2021, https://evolution.berkeley.edu/evolibrary/article/evo_30). Used with permission.

\subsubsection{Soybeans}

Corn is the US's number-one crop by weight produced, and coming in second is another invisible plant in our food supply: the soybean. Just as Mesoamericans would seem to live and breathe corn, one would think East Asian countries like China and Japan would be the world's greatest growers and consumers of soybeans. Not so: the US is the world's number-two soybean producer (after Brazil), and Americans consume more soybeans per capita than any other country.

But while Chinese and Japanese food is popular in the US, Americans don't eat huge amounts of soy sauce, tofu, or other obviously soy-based products. Like corn, soy is hidden in our food, present in the form of oil, various soy-derived additives, and, most of all, as animal feed. Also like corn, more and more soybeans are being used to produce fuel; in this case, biodiesel.

The result is that the seemingly enormous variety of American processed foods consists, to a shocking extent, of only these two plants. According to food journalist Michael Pollan:

"Along with the soybean, its rotational partner in the field, corn has done more than any other species to help the food industry realize the dream of freeing food from nature's limitations and seducing the omnivore into eating more of a single plant than anyone would ever have thought possible."

"Rotational partner" refers to the fact that corn and soybeans are actually grown on the same land, though in alternate years. Corn is a highly nutrient-demanding crop, quickly exhausting soil, while soybeans, as a legume, actually enrich the soil, so the two complement each other perfectly.

\subsection{What Americans eat, revisited: Regional cuisines}

Processed foods, however, only comprise one part of the US's diverse food culture. Due to the country's large geographical size and diversity, it should come as no surprise that there are a variety of regional foods in the US.

A full overview of US cuisine could easily fill a sizeable book. Thus I will only hint at its full diversity and highlight some of the best-known, most culturally significant foods. 
New England: Much of traditional New England food dates back to colonial times, consisting of simple fare that emphasizes both local produce (seafood, turkey, apples, blueberries, maple syrup) and products of maritime trade (molasses).

Clam chowder - a creamy soup with clams, bacon and potatoes.

Boston baked beans - beans slowly baked with tomato and molasses (origin of Boston's nickname "Beantown").

Blueberry pancakes with maple syrup - a classic New England diner breakfast.

Chesapeake Bay: Soft-shell crabs, crab cakes (a crabmeat croquette)

Appalachia: Country ham - a smoked, cured and aged ham similar to German Black Forest ham.

Bourbon whiskey - the whiskey-making tradition was brought to Appalachia by Scottish immigrants, but uses corn in place of barley, giving it a unique flavor. Well-known brands include Jack Daniels and Jim Beam.

The South: Of all the US regions, the South is the place where food has the greatest cultural value, symbolic value, and variety.

Southern barbecue, a widely misunderstood concept, is not grilling. According to American food scholar Harold McGee,

"Barbecuing is the low-temperature, slow heating of meat in a closed chamber by means of hot air from smoldering wood coals. It's an outdoor cousin to the slow oven roast, and produces smoky, fall-apart tender meat." (McGee, p. 157)

Indeed it does. What's more, every microregion of the South has its own style of barbecue, depending on the type of meat, the way it's cooked, the sauces used, etc. The "whole-hog" barbecue, a.k.a. a "pig pickin" (where an entire pig is barbecued and eaten) is a gastronomic event comparable in significance to the Slovak zabijačka. Pig pickin's are often a part of large gatherings, such as weddings, and as a surefire way to draw crowds, they are also a fixture of political rallies in the South.

Biscuits - rich, buttery, often flaky buns strikingly similar to Slovak pagáče.

Fried chicken and watermelons - while Southerners didn't invent fried chicken or watermelons, they are certainly ubiquitous in the South and of particular cultural significance. In fact, eating fried chicken and watermelons has been a racist African American stereotype since the slavery era, propagated by "minstrel shows", where white performers wore "blackface" (black face paint) and ridiculed black people. Even today, watermelon and fried chicken are used in racist propaganda to mock black politicians like Barack Obama. Of course, this unfortunate legacy doesn't keep anyone, regardless of race, from eating either food.

Soul food - traditional African American cuisine. African slaves had a major impact on Southern food, helping to introduce or popularize a variety of crops (rice, peanuts, greens, okra, sesame seeds, sweet potatoes, chili peppers) and preparation techniques. Thus it is difficult to separate African American cuisine from Southern cuisine in general. That is why the term "soul food" is most common outside of the South, in places where African Americans emigrated to in the 19th and 20th centuries, such as northern industrial cities.

Southern Louisiana: Originally home to two distinct cuisines-Cajun cuisine (the food of the French-Canadian immigrants from Acadia), and Creole cuisine (a combination of foodways from in and around New Orleans, e.g. Caribbean, African, Spanish and Choctaw), which have by this time blended together irreversibly. 
Well-known dishes include: jambalaya - a rice-and-seafood-based dish influenced by Spanish paella, and gumbo - a stew usually featuring shellfish, okra and the Choctaw seasoning filé powder, made from the leaves of the sassafras tree, Andouille sausage.

Tex-Mex: Texan cuisine is one of the US's most influential cuisines, since it is nearly universally presented as Mexican cuisine, especially in Europe. So next time you go to a "Mexican" restaurant, keep in mind that the following dishes are Texan, not Mexican, and are often unheard of in Mexico itself:

Chili con carne: a stew of meat and chilies. Outside of Texas, beans and tomatoes are often added.

Fajitas: Grilled meat, peppers and onions, often served with wheat tortillas.

Southwestern cuisine: A branch of Mexican cooking that revolves around three staples of Native American agriculture: corn, chilies and beans. And as in every area of Southwestern culture, the aesthetic plays a major role. Ingredients like motley, multicolored Indian corn and deep maroon dried chilies double as decorative motifs in many a Southwestern home.

Posole: A hearty soup of hominy corn and chilies in a pork broth.

Enchiladas: Rolled corn tortillas stuff with meat, covered in cheese and chili sauce and baked.

\subsubsection{City foods}

Most US cities don't possess a single, cohesive cuisine of their own, but many of them are hotbeds of culinary innovation, from street food to fine dining, and many of their local foods have become symbols of the cities themselves. Though virtually all of these foods have their origins in a particular immigrant community, they've been embraced universally. And the ethnic enclaves they've come from - the Chinatowns, Koreatowns, and Little Italys in various cities - have become food meccas in their own right. I would even argue that food plays a major role in establishing ties and cultivating tolerance between different ethnic communities in the US. After all, how much animosity can you bear towards someone who cooks you delicious food?

New York City: As the US's premiere city of immigrants, New York City is a mix of cultures from around the world, and this is clearly evident in the way New Yorkers eat.

Bagels - ring-shaped buns brought to New York by Ashkenazi Jews from Eastern Europe.

Jewish delicatessens (delis) - not a dish, but a type of restaurant; in fact, two types of restaurant. Since Jews traditionally keep kosher, i.e. separate dairy foods from meat, there are actually two kinds of Jewish deli - milchig, where bagels, lox (smoked salmon), cheese blintzes, matzo ball soup, and other meatless delicacies are sold, and fleishig, featuring traditional cold cuts like corned beef and tongue.

New-York-style pizza - one of the many American variations on pizza, originally brought to the US by Neapolitan and Sicilian immigrants. In New York City, pizzas are big, thin "pies", sold in individual slices as street food.

Chicago: Chicago-style pizza - the opposite extreme from New-York-style pizza: several centimeters thick, with a pastry-like crust and the tomato sauce on top.

San Francisco: Sourdough bread - During the gold-rush era, sourdough (a natural yeast culture) was among a prospector's most cherished possessions, since it was the key to making bread. The living source of yeast, in the form of a ball of dough, had to be protected from cold at any cost, and according to legend, many even kept it safe and warm in their underwear. Eventually experienced prospectors were themselves referred to as "sourdoughs". After the gold rush, the sourdough tradition remained, and today San Francisco is known for its bread bakeries. The city has even lent its name to a particular species of lactic acid bacteria present in sourdough: Lactobacillus sanfranciscensis. 


\subsection{When Americans eat: Mealtimes}

Mealtimes are another key difference between American foodways and those of Britain and Slovakia.

"In colonial times, American meal patterns followed European practices...As the first meal of the day, breakfast...was eaten immediately upon rising or a few hours later, after the earliest chores have been completed...Working men and schoolchildren returned home for dinner, the main meal of the day, which was traditionally served in the early or late afternoon...Supper, the last meal of the day, was light and, sometimes, optional. It was eaten in the early evening... The traditional meal pattern began to change during the mid-nineteenth century, due in part to the growth of cities and the shifting of occupations of American men. The first meal to change was dinner. As towns and cities grew, it became more difficult for workers to return home for dinner at midday as the distance between home and the place of work increased...Dinner, the most important meal of the day, moved to the evenings, when the family could dine together at a more leisurely pace. The midday repast came to be called lunch...and evolved into a small, light, and frequently rushed meal - often something brought from home in a tin pail or a brown bag, or a quick bite in a workplace cafeteria. Sandwiches, soups, and salads became common luncheon foods."

There are several interesting inferences to be made here. First, it seems that the growing distance of American workers' commutes has played a role in shifting the main meal, still known as dinner, from midday to evening, when it is more practical for the whole family to meet. According to market research commissioned by US food manufacturers, most US families have at least five meals together per week, while $74 \%$ still "wish they could have more meal time together". Even in my relatively relaxed childhood household, all family members were expected to be present together at the dinner table.

The evening meal has long been seen as having major social significance in the US. Countless media images (as well as my own experience) reinforce the idea that dinnertime is family time, a time for the family to not only eat, but talk, share news, have important discussions and connect emotionally. This important sociocultural institution was preserved in the face of the modern working schedule by moving it to the evening.

While I don't have hard data on Slovak mealtime behavior, I can make some tentative generalizations based on my observations and conversations. Despite a modern working schedule similar to the US, the midday meal (obed) seems to have remained the main meal for most Slovaks. As a result, this main meal is usually eaten away from the home, in the workplace or in school. One advantage of this is that Slovak cafeteria fare, in my experience, is often heartier and healthier than in the US. Recently Americans have also begun to recognize that eating a large meal in the evening can lead to health problems such as weight gain. But considering how family-oriented most Slovaks are, the question remains: if the evening meal (večera) isn't a formal, sit-down gathering, when do Slovak families meet during the workweek?

Like the traditional English breakfast but unlike the Slovak morning meal (raňajky), breakfast in the US is also traditionally a large meal. While many American professionals limit themselves to a light "continental" (i.e. European-style) breakfast, many others eat a big traditional breakfast, often at a fast -food restaurant or a diner. In fact, though dinner may be the most culturally significant meal, breakfasts are often higher in calories. These big breakfasts are thought to hearken back to a time when most people worked hard in the fields all day, and for those with physically demanding jobs, like construction workers and movers, they still provide a much-needed energy supply.

Which leaves lunch, the replacement for dinner as the midday meal. Compared to breakfast and dinner, an American lunch is often an afterthought - a sandwich or leftovers brought from home or a light salad at a cafeteria. 


\subsection{Where Americans eat}

In many cultures' foodways, eating location also plays a major role. So where do American eat?

\subsubsection{TV dinners}

Though it may be, like televisions themselves, on the way out, the TV dinner is an important concept for understanding the development of convenience foods and prepackaged meals, a major influence on the way Americans and people around the world eat.

The idea of a complete frozen meal in a single tray was first developed for airplane travelers and the military. In the $1950 \mathrm{~s}$, these meals began to be sold to consumers as a convenient alternative to home cooking. The arrival of affordable microwave ovens in the 1970s made preparing such prepackaged meals even quicker and easier, ushering in an era when home cooking became rarer and rarer.

At the very same time, a reverse trend was starting to simmer. Julia Child, the best-known American TV chef, made her onscreen debut in 1962, catapulting both herself and the TV cooking genre to fame. Through cookbooks and cooking shows, Americans were rediscovering home cooking, no longer as a necessity, but as a leisure activity.

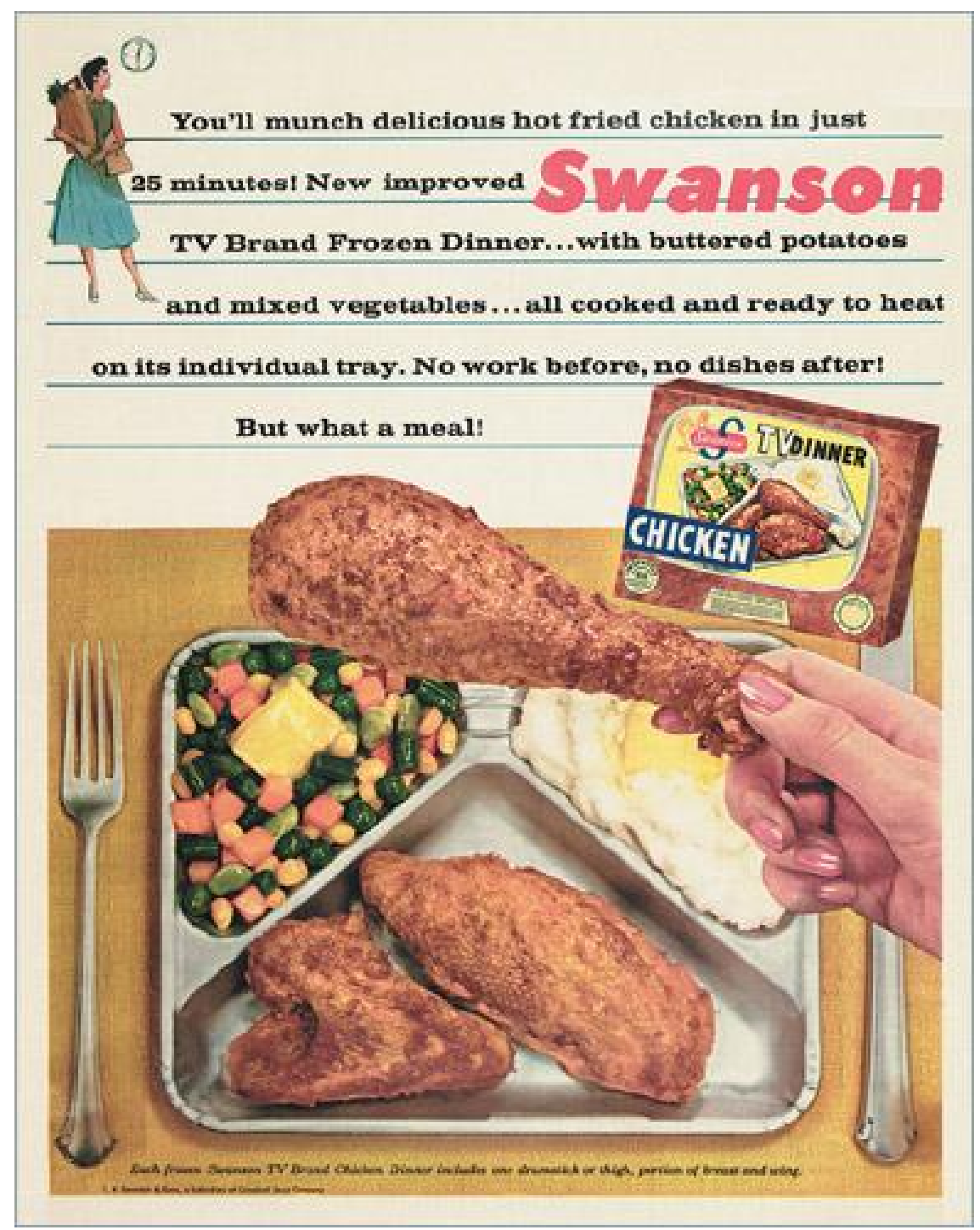

Figure 23: A TV dinner advertisement (C.A. Swanson \& Sons, 1956) 
The classic cookbook Joy of Cooking has long been a fixture of American kitchens, as well as an indicator of American culinary tastes and trends. In his introduction to the 1997 edition, Ethan Becker writes:

"My Granny Rom (known to the rest of the world as Irma Rombauer) wrote Joy in $1931 . .$. she wrote it for the times... when domestic help was fast becoming a thing of the past and women all over the country were once again heading to the kitchen. This book made cooking socially acceptable, fun and easy, and helped change the perception of cooking from a chore to a joy. Over the next twenty-two years, Irma revised the book, always keeping current with the times, even writing for the days of war rationing...And what times these are! Who would have thought twenty-five years ago that cooking would be a noble career choice and one of America's favorite pastimes? Since Joy's last version, the food community has grown to thousands of experts, cooking magazines abound, and literally tens of thousands of cookbooks have been published."

By 1999, 38.2 percent of Americans identified as "foodies".

But to what extent does this media phenomenon translate into more actual home cooking? According to a 2012 study published in Nutrition Journal, Americans' rate of home cooking stopped falling in the mid-90s, but hasn't actually begun to increase. So while cooking may be fun for many Americans, for most it has yet to truly overcome the convenience of eating out or eating from a box.

And what about Europe? According to recent studies, home cooking is still in decline among most Europeans, with more and more of people's food budget going to fast food restaurants and prepackaged food. Yet in most Americans' eyes, Europe is still seen as a bastion of traditional gastronomy. Is this decline simply a delayed version of what happened to home cooking in the US in the 20th century? Or something else entirely?

\subsubsection{Diners}

During the industrial revolution in the mid-19th century, traditional agrarian mealtimes were being compromised by urban workers' schedules. But these workers still had to eat. Bringing a "brown-bag lunch" made at home was one option, but a more attractive, fresher, hotter alternative was also emerging: street food. For both consumers and vendors, one of the most convenient ways of serving street breakfasts and lunches was in the form of the lunch cart, a hand-pushed or horse-drawn cart on wheels selling portable meals, such as egg sandwiches, to passersby. As lunch carts expanded into larger and more elaborate lunch wagons, they began to resemble another mobile kitchen: the railway "dining car".

By 1923-1924, this development had culminated in the full-fledged diner - a sit-down restaurant modeled after a railway dining car with its own unique aesthetic. The elongated, rectangular, train-car shape of the building enclosed a long, narrow space with a countertop stretching nearly its entire length. On one side of the counter stood the cooks and waitstaff (often the same people) surrounded by the tools and wares of their trade; on the other side sat patrons on high, round, padded barstools. This individual seating was oriented towards speedy workweek meals, but like a bar, it also encouraged interaction between patrons and staff. Later, wider diners incorporated a row of tables or even "booths", individual tables with fully-padded benches on either side, creating more intimate spaces for families and couples to dine in. Much of these surfaces were covered with chrome, vinyl, and black-and-white tile, an art-deco touch which remains a part of the diner's design language to this day. 


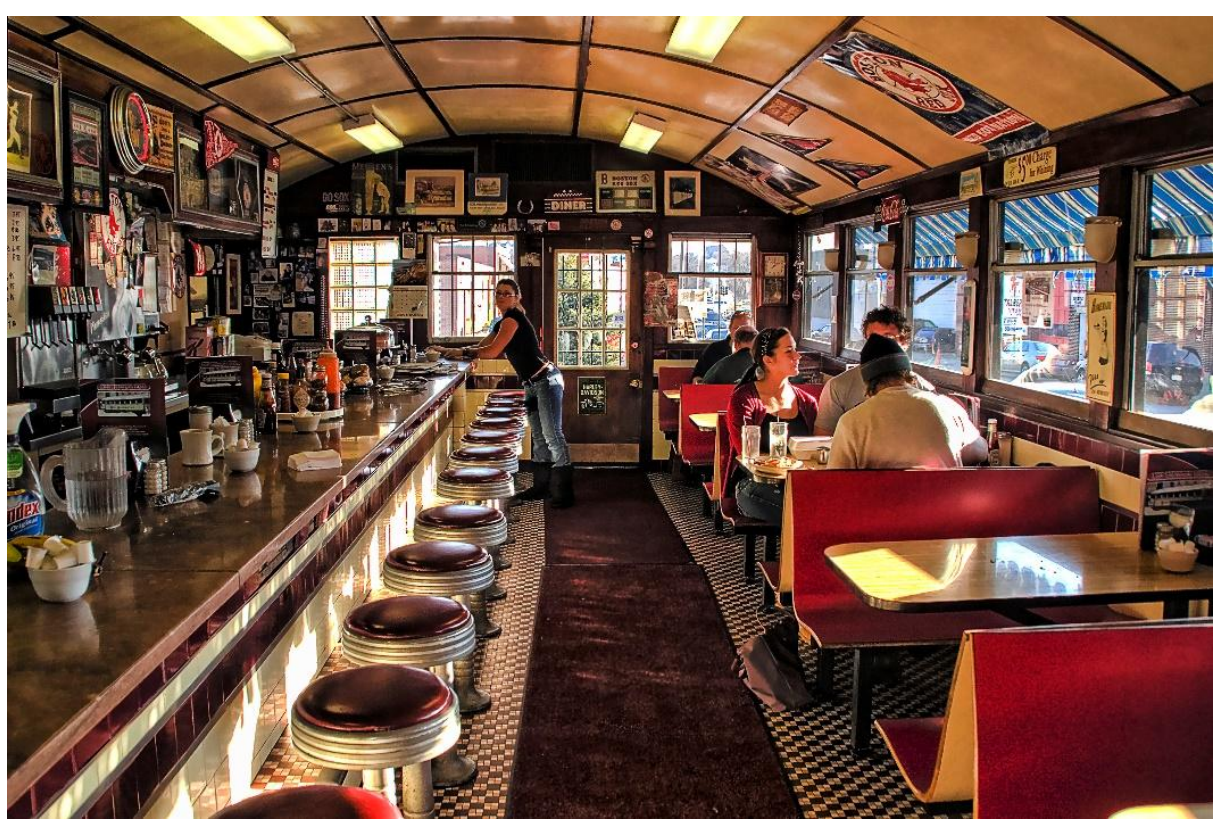

Figure 24: Miss Worcester Diner in Worcester, Massachusetts. Constructed by the Worcester Lunch Car Company in 1948. (liz west, "Miss Woo Diner inside", https://www.flickr.com/photos/calliope/4147290484/, Creative Commons Attribution 2.0 Generic)

The diner quickly became both a ubiquitous type of American restaurant and an iconic space in the American imagination, primarily through art, film and television. One of the most recognizable American paintings of all time, Edward Hopper's "Nighthawks" (Fig. 5), itself inspired by a diner scene in the Ernest Hemingway story "The Killers", in turn influenced the story's film adaptation, as well as an entire Hollywood genre - film noir - where diners acted as a backdrop for numerous scenes. Hopper's angular diner combines both the anonymity (the individual seats, the dark-clothed, brooding men, the woman's withdrawn posture) and the public exposure (the inescapably wide windows, making every passerby a voyeur) that characterize urban life, while the cook's bleached uniform lends him the appearance of an angel, his bright-walled sanctuary a haven of light for the wretched denizens of the dark city night.

In more recent times, diners have become a staple location for movies and television series of nearly every genre. From the Moondance Diner in Friends and the Peach Pit in Beverly Hills, 90210 to the shocking opening robbery scene in Pulp Fiction, the list goes on and on.

\section{Pop culture's influence on our own mental images}

Like many American cultural institutions, the diner is now so deeply connected with pop culture that it is difficult to separate the real dining experience from the virtual experience mediated by film and television. As an American myself, and an unabashed diner-lover, I'm left with the question: is it my own memories or onscreen images that have contributed more to my own mental image of the diner? The same question could be asked of everything from Thanksgiving to the legal system, as it's highly likely that I've seen more Thanksgivings onscreen than I've experienced in real life, and I've certainly seen more US court proceedings onscreen than in real life.

Complicating things even more, American media is exported around the world, along with its accompanying stereotypes. When a Slovak and I were walking in a New England woods, she picked up an acorn and remarked upon its shape: "It's just like the ones on TV!" She'd seen the seed of the American white oak in countless movies and TV programs, but never in real life. Acorns are a rather innocuous example, but consider some of your more significant mental images, perhaps even your values - which do you think might be influenced by the Slovak media or, indeed, imported American media? 


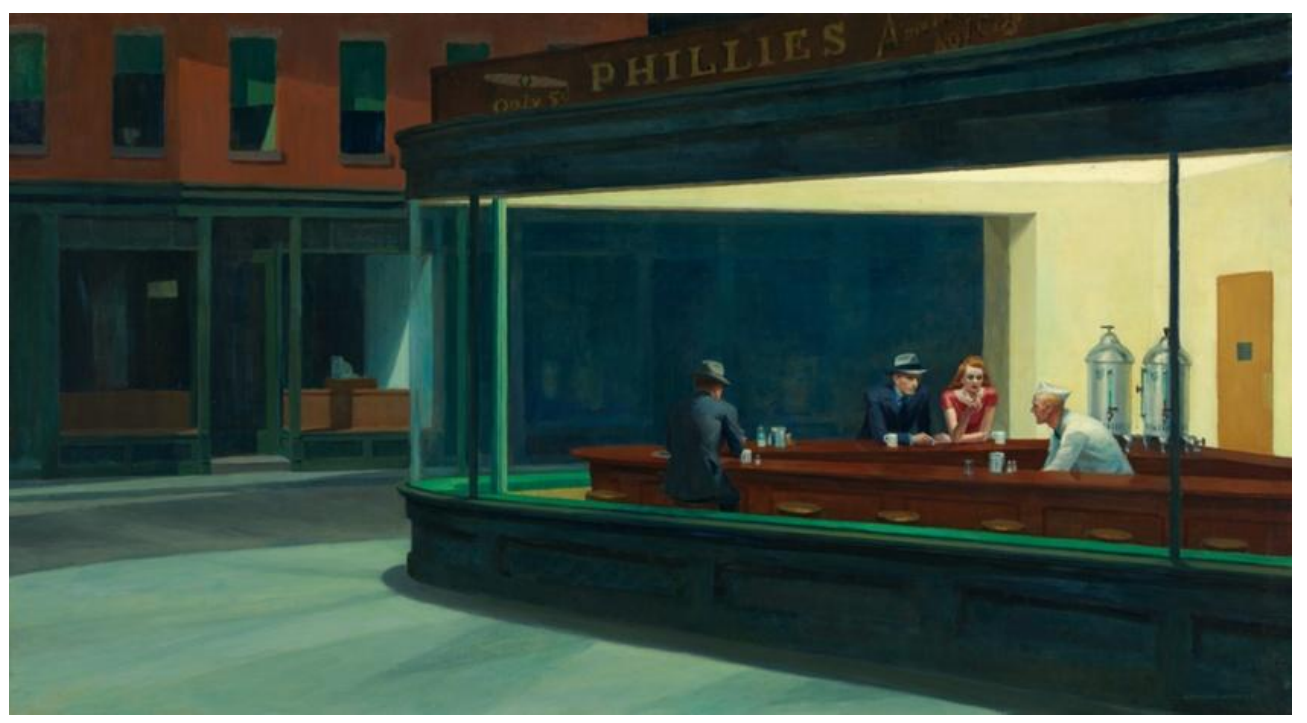

Figure 25: Edward Hopper: "Nighthawks" (1942) (public domain, https://www.artic.edu/artworks/111628/nighthawks)

\subsection{Some US/UK vocabulary differences}

Like transportation (or "transport" in British English) and clothing, food is one of the areas of vocabulary where American English and British English differ most. It seems that Slovak has been influenced by both American and British English in this respect (see the terms in bold). Not all these foods exist in exactly the same forms in all three cultures, so in the case of an American term that does not have an exact equivalent in British English or Slovak, I have listed the next closest thing, preceded by a double tilde $(\approx)$. This list is by no means exhaustive; these just are some of the most common differences.

\begin{tabular}{|c|c|c|}
\hline American English & British English & Slovak \\
\hline chips & crisps & čipsy \\
\hline French fries & chips & hranolky \\
\hline pudding & custard & puding \\
\hline biscuit & $\approx$ scone & pagáč \\
\hline cookie & biscuit & sušienka \\
\hline appetizer & starter & predjedlo \\
\hline entrée & main course & hlavné jedlo \\
\hline muffin & (American) muffin & mafin \\
\hline cupcake & $\approx$ fairy cake & mafin (s polevou) \\
\hline zucchini & courgette & cuketa \\
\hline arugula & rocket & rukola \\
\hline eggplant & aubergine & baklažán \\
\hline jello & jelly & želé \\
\hline jelly & $\approx \mathbf{j a m}$ & džem (rôsolovitej konzistencie) \\
\hline broil (v.) & grill & grilovat' (v rúre) \\
\hline oatmeal & porridge & ovsená kaša \\
\hline
\end{tabular}




\begin{tabular}{|l|l|l|}
\hline corn & maize & kukurica \\
\hline wholegrain & wholemeal & celozrnný \\
\hline candy (uncountable) & sweets (countable) & sladkosti \\
\hline scallion & spring onion & cibul'ka \\
\hline can & tin & konzerva \\
\hline diner & $\approx$ café & $\approx$ bistro \\
\hline cafeteria & canteen & závodná/školská jedáleň \\
\hline pancakes & Scotch pancakes & $\approx$ dolky \\
\hline
\end{tabular}

\section{Follow-up}

1. How many New World crops that you eat can you name?

2. What are the US's top two crops by volume? What are they used for?

3. Which US regional dishes have you tasted? Which would you like to taste?

4. How does your eating schedule compare to that of a stereotypical American?

5. Can you think of any films, TV shows or books with a diner scene? 


\section{US Regions (by Michael E. Dove)}

We Americans are a bundle of paradoxes.

We are mixed in our origins, and yet we are one people.

(David Hackett Fischer)

In this chapter you will learn:

- How is the US split up into regions?

- What features distinguish these various regions?

\begin{tabular}{|c|c|}
\hline New England & the Great Plains \\
\hline the Mid-Atlantic & the Cherokee Nation \\
\hline the grid plan & the Mountain States \\
\hline Appalachia & the Southwest \\
\hline the South & the Navajo \\
\hline the Great Migration & the Central Valley \\
\hline the Midwest & Silicon Valley \\
\hline the Rust Belt & the Pacific Northwest \\
\hline
\end{tabular}

\subsection{Official regions?}

Unlike Slovakia, the United States does not consist of distinct official regions (aside from the states themselves). There are instead many official and unofficial regions, which vary depending on the particular needs of the given context. Examples include courts districts, climate zones and census regions.

\subsection{Unofficial regions}

In Americans' discourse, however, a variety of unofficial regions are referred to. These roughly correspond with historical, cultural, and environmental differences across the country. These could be compared to Slovakia's "traditional" regions such as Záhorie, Liptov, etc., which, despite their unofficial status, continue to be of major cultural significance.

Keep in mind that these borders are approximate, debatable, even controversial (as in the South, for example), and do not necessarily correspond to state borders, which are primarily of legal and political significance. An internet search of "US regions" will show that there are myriad ways of dividing up the country. We have opted for a map that includes the regions most commonly referred to in US discourse. For a larger version, see Appendix E on p. Error! Bookmark not defined. 


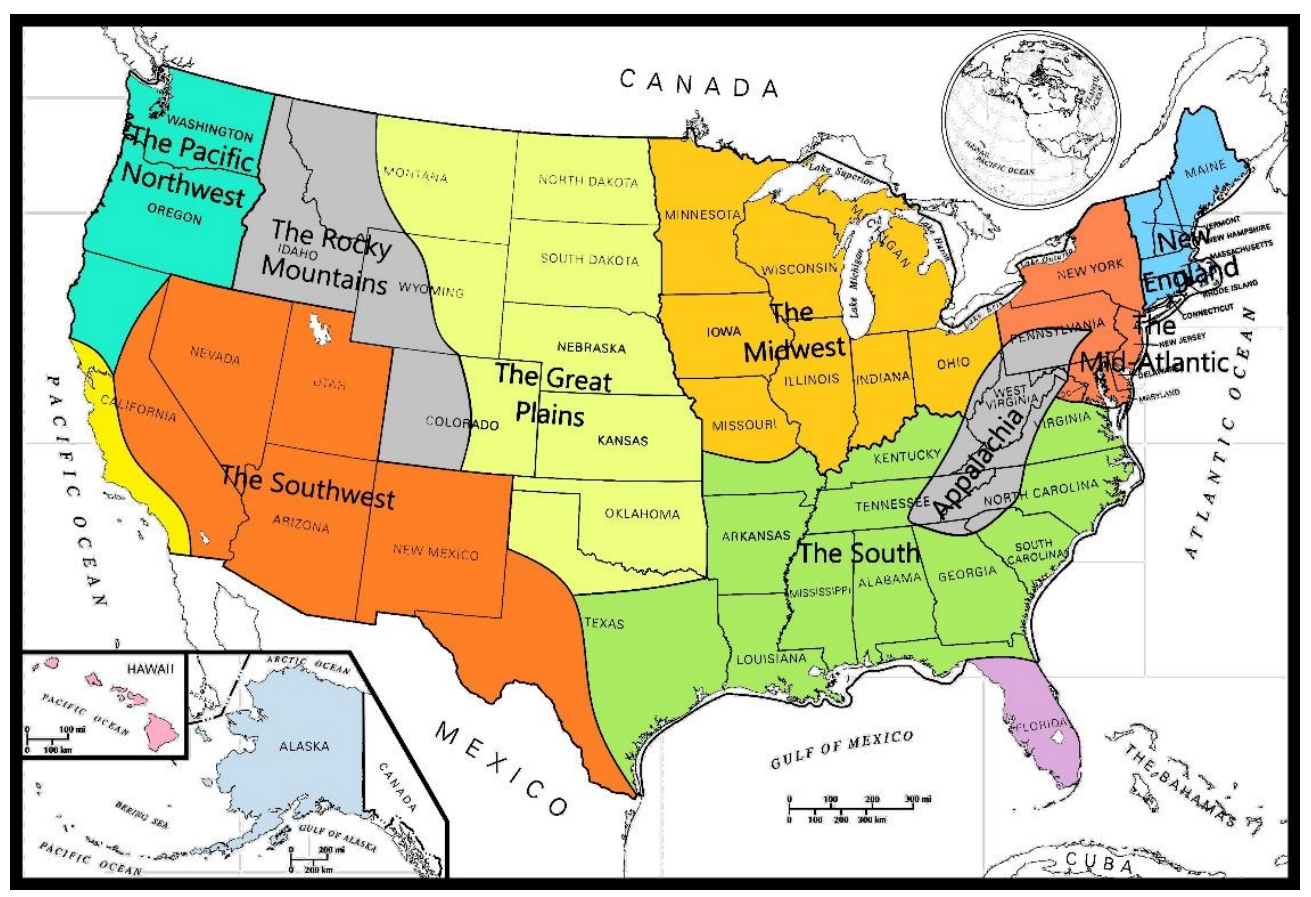

Figure 26: Unofficial US regions

\subsection{A brief tour of the US}

In the following section, we will take you on a guided tour of the regions in the map above, describing some of the particularities that distinguish them and how they are viewed by the country as a whole.

\subsubsection{New England}

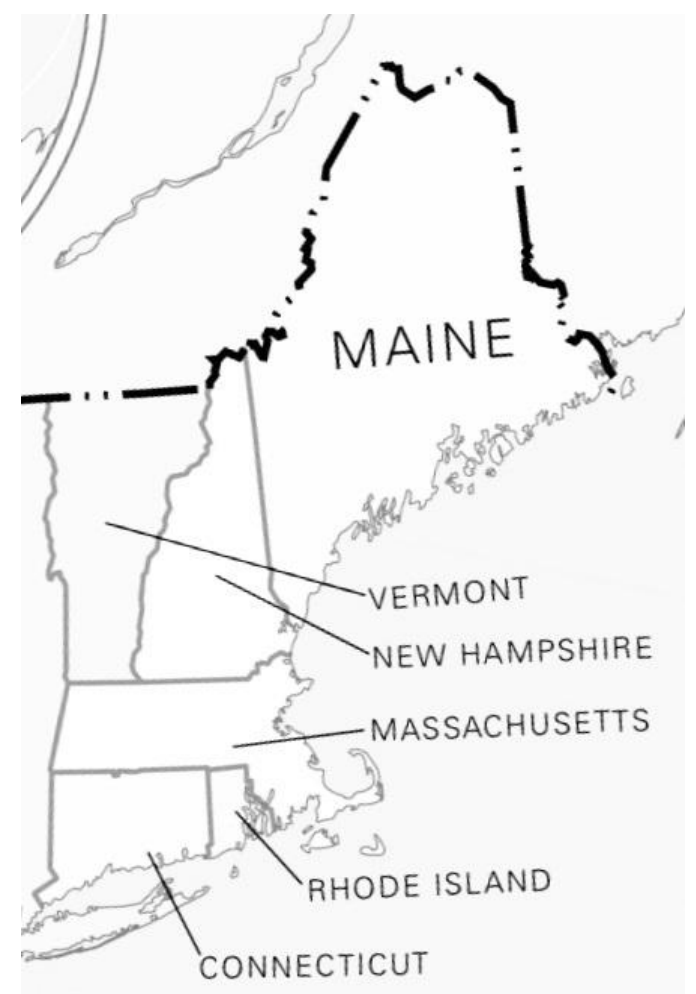

Figure 27: The Six States of New England 
New England is the most clearly defined of all the US regions, consisting of six states: Maine, New Hampshire, Vermont, Massachusetts, Connecticut, and Rhode Island.

In pre-Columbian times, present-day New England was inhabited by Algonquin tribes such as the Wampanoag, Massachusett, Mohegan and Abenaki. Farming, gathering, fishing and hunting provided goods for their own consumption as well as for trade with other regional tribes. The first Europeans they encountered were usually French, Dutch and English fur traders, who bought pelts from them.

Home to some of the earliest English colonies, New England has a long history of Anglo-American culture, dating to the Pilgrims' founding of the Plymouth Colony in 1620. The region continued to play a strong role in many pivotal events of the nation's history, including the American Revolution.

\section{Economy}

Thanks to its rugged coastline, dotted with natural harbors and islands, the region naturally lends itself to maritime trade. Boston, the largest city in the Thirteen Colonies (and still New England's largest city), became a major port in the various triangular trade routes connecting England, the Caribbean and New England. At first, exports generally consisted of fur, timber, fish (preserved with salt imported from England or the Caribbean) and alcohol (distilled from Caribbean molasses). This later expanded to include whale oil and whalebone; the US whaling industry was concentrated in New Bedford, Massachusetts, where the opening of Herman Melville's novel Moby-Dick is set. The onset of the industrial revolution came another, more lucrative export: fabric, woven in New England's industrial textile mills, using cotton from Southern slave plantations. Starting in the late 19th century, even ice began to be exported as far as Australia.

Today, New England's economy is decidedly post-industrial; the old textile mills are now used as museums or cultural centers. In terms of manufacturing, the region now focuses on medical equipment, weapons and other high-tech products.

Though certain food products retain cultural significance, such as lobster, maple syrup and local dairy products, the bulk of the economy is service-oriented. Education is particularly well represented, with a tradition dating back to 1635, when the Puritans founded Boston Latin, the country's first public school (still in existence). The Boston area, for example, is home to over 50 colleges and universities, including Harvard and the Massachusetts Institute of Technology (MIT). The area's highly educated workforce has given rise to new industries, such as the rapidly growing biotechnology sector, closely connected with local universities.

\section{Demographics}

This and subsequent sections on the ethnic makeup of each region are based on the U.S. Census Bureau's "Largest Ancestry" map, available at https://www.census.gov/history/pdf/ancestry.pdf on page 8 . We recommend referring to that map while reading these sections.

You may wonder why we use a map from 2000 in 2018. The reason is that the 2000 census was the last US census when questions regarding ancestry were asked. The question "What is this person's ancestry or ethnic origin?" was removed from the subsequent 2010 census. Nevertheless, from a demographic perspective, 20 years is less than a single generation, and so we still consider the data from the 2000 census relevant for our purposes.

Today, New England's population is quite diverse, but some clear local patterns remain:

- In wilds of the far north, on the border with Canada, French Americans predominate, descendants of some of the first European settlers in the area. Famous New Englanders of French descent include patriot Paul Revere, transcendentalist philosopher Henry David Thoreau (Walden, "Civil Disobedience") and beat writer Jack Kerouac (On the Road). 
- In rural, agrarian northern New England, the descendants of English immigrants, arriving throughout the colonial period, remain. Given their early arrival and cultural dominance, it should come to no surprise that New Englanders of English descent are well represented in US society, represented by the likes of founding father John Adams, poets Henry Wadsworth Longfellow and Emily Dickenson, transcendentalist philosopher Ralph Waldo Emerson, novelists Nathaniel Hawthorne, Harriet Beecher Stowe (Uncle Tom's Cabin) and the transcendentalist-raised Louisa May Alcott (Little Women), horror writers Edgar Allan Poe, H. P. Lovecraft and Stephen King, painter Winslow Homer, the Bush family of politicians, actor/filmmakers Matt Damon, Ben Affleck and Casey Affleck, and many more.

- In more urban, industrialized southern New England, the predominant English heritage gives way to Irish Americans, most of whose ancestors arrived during or after the mid19th-century Irish Potato Famine. Famous Irish New Englanders include former president John F. Kennedy, writer Cormac McCarthy and talk-show host Conan O’Brien.

- Further south and west, moving towards New York City, the Irish plurality is displaced by Italian Americans, representing one of the 20th century's largest waves of immigration to that city and the area around it.

- Also worthy of note is the significant Portuguese American population in and around New Bedford, Massachusetts, which began with arrival of Azorean whalers in the 19th century.

\subsubsection{The Mid-Atlantic}

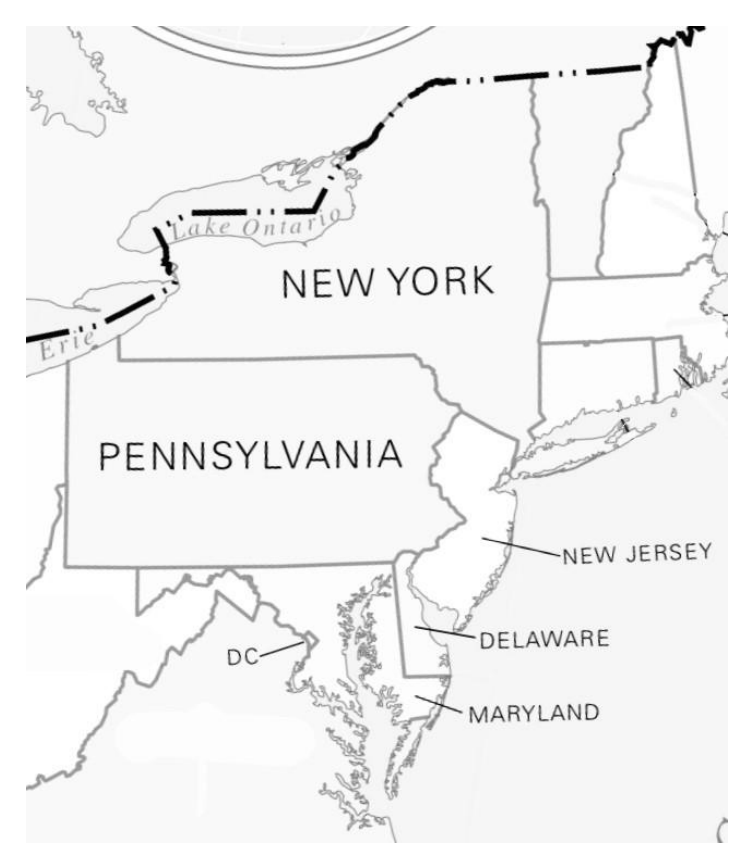

Figure 28: The Mid-Atlantic states

Bordering New England to the west are two larger states and several smaller ones that form a diverse region known as the Mid-Atlantic. Like New England, the Mid-Atlantic has a long history of AngloAmerican settlement; unlike New England, the history of that settlement is highly varied, giving way to a variety of cultures and identities. While many people identify as New Englanders, few MidAtlantic folk identify as such, more often associating themselves with their state, city or local subregion. 


\section{The Northeast Megalopolis}

The coastal portion of the Mid-Atlantic is the most densely populated part of the US, stretching from New York City (or even Boston) to Washington, D.C. This conglomeration of large cities sometimes referred to as the East Coast Megalopolis. If Boston is included, the area's population exceeds 50 million inhabitants.

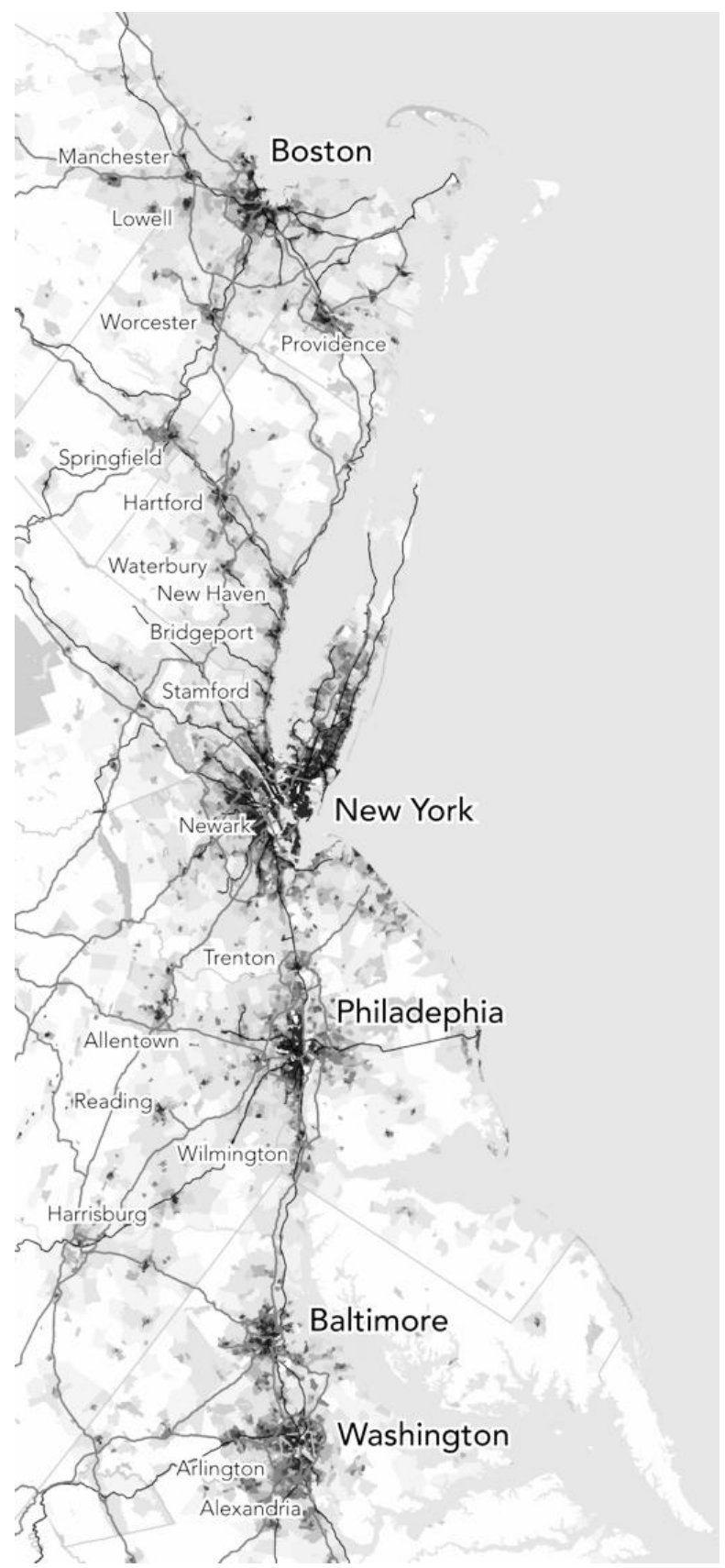

Figure 29: The cities of the Northeast Megalopolis

Continuing along the eastern seaboard southwards from Boston, the urban character of southern New England only intensifies as you approach New York City, the US's largest and most famous city.

\section{New York City}

"New Amsterdam", as the originally Dutch colony was first called, or "The Big Apple", as it is sometimes known now, needs little introduction. Thanks to its oversized presence in US culture, 
many of the distinctive aspects of this city are common knowledge among Americans, even those who have never visited it in person.

With a population of over 8.5 million, New York City is indeed massive, but it is perhaps better described as a city of cities. Specifically, it is divided up into five areas known as "boroughs", each of which constitutes its own county and functions as a semi-autonomous city in its own right.

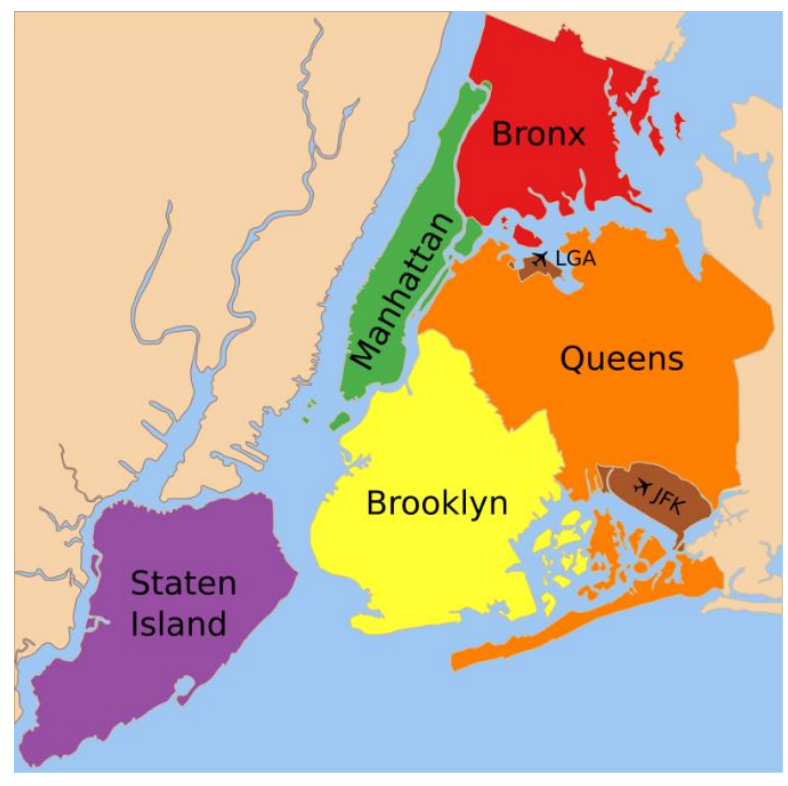

Figure 30: The five boroughs of New York City (Nafsadh, https://commons.wikimedia.org/wiki/File:5_Boroughs_Labels_New_York_City_Map.svg, public domain)

Of all five boroughs, the one that is best known and most emblematic of the city is undoubtedly Manhattan, a long, narrow island between the Hudson River and the East River. Bought for a pittance from Lenape Indians in 1626, Manhattan began as a Dutch colony. After conquering the island, the English renamed it New York. By the 19th century, New York had become the US's largest city. To make room for the city's growing population, a plan was adopted in 1811 for the city's expansion, covering nearly all of Manhattan Island with the now-familiar grid plan. 


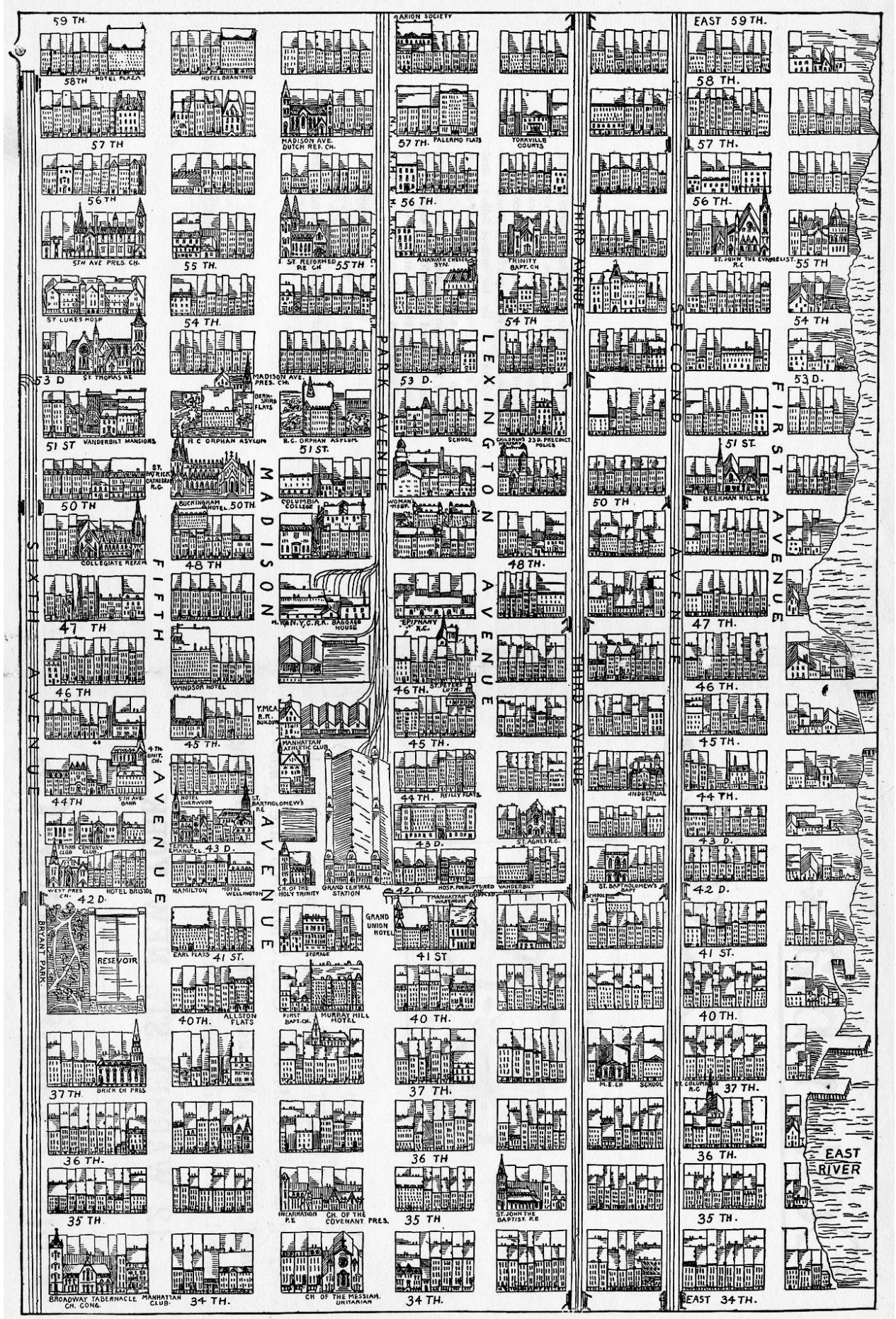

Figure 31: Manhattan's grid plan (“Map of Midtown Manhattan”, published by Sun Manhattan, 1890, from the Seymour B. Durst Old York Library Collection)

In this street plan, most of roads are numbered. The roads running east-west across the island, numbered from 1 to 228, are named "streets", e.g. "6th Street", "110th Street" etc. The roads running north-south up and down the island are called "avenues", e.g. "5th Avenue". Like a Cartesian graph, this allows for accurate navigation using the street and avenue name as coordinates. If you want to meet someone somewhere in Manhattan, all you need to say is "I'll meet you at 27th [Street] and 8th [Avenue]".

New York City is the center of many spheres of activity in the US, from the financial industry (Wall Street) and the news media (Times Square) to art (Chelsea) and theatre (Broadway). Its contributions to global culture are numerous, with hip-hop (originally from the Bronx) being just one among them. 


\section{Philadelphia}

Another major city of the colonial era, Philadelphia, or "the City of Brotherly Love", played a pivotal role in the struggle for independence; after the Revolutionary War, it served as the nation's capital for a decade while Washington, D.C. was being constructed.

For much of the 20th century, Philadelphia was a major industrial city. In the later decades of the 1900 s, deindustrialization took a heavy toll in the form of high unemployment and crime, in part because Philadelphia lacked the diversified economy of Boston and New York City. Nevertheless, it remains a vibrant, proud city, exemplified in the local tradition of community murals - large paintings on the sides of buildings, often created collaboratively with local residents.

\section{Washington, D.C.}

The nation's capital is a city of contradictions. Home to all three branches of the federal government and an array of other federal institutions, it was also long stricken by crime and poverty, though this has improved in recent years.

The divide between the local population and the federal government is further emphasized by an odd anomaly in US democracy: taxation without representation. Originally a Revolutionary War-era slogan, "Taxation without Representation" is now used by Washington, D.C. residents (and is even featured on car license plates in the district) to describe their political plight. Because Washington, D.C. is not a state, its residents are not fully represented in Congress, yet they are fully required to pay federal taxes (unlike residents of other non-state territories like Puerto Rico). Changing this would require an act of Congress, which is unlikely due to D.C. residents' lack of representation.

\section{Demographics}

The New York City metro area is characterized by enormous ethnic diversity, with hundreds of languages spoken, but as of the 2000 census, the most represented ethnicities were:

- Dominican Americans, most of whom came during or after the unrest of the 1960s in the Dominican Republic. Dominican New Yorkers have made a strong mark on the arts, particularly authors Julia Alvarez and Junot Díaz, as well as Broadway composer, playwright and actor Lin-Manuel Miranda (Hamilton).

- Puerto Ricans, who are US citizens by birth, Puerto Rico being a US non-state territory. The Second World War, when there was a high demand for workers to fill the position left by drafted soldiers, prompted a wave of Puerto Rican immigrants, transforming neighborhoods such as Manhattan's East Harlem into "Spanish Harlem". Puerto Rican New Yorkers include many famous entertainers, such as pop artists José Feliciano and Marc Anthony, singer/actress Jennifer Lopez and jazz musician Tito Puente.

- New York City's African American community is one of the city's oldest, dating back to the early 17 th century, when they arrived as slaves. When slavery was abolished in the state in 1827, the city became a major center of African American culture, home to the first African American newspaper (Freedom's Journal). The local community grew enormously during the Great Migration of the early 20th century, when black people moved from the rural South to northern cities, fleeing the oppression and violence of the segregationist "Jim Crow" era. The Manhattan neighborhood of Harlem is most commonly associated with early-20th-century African American culture, home to the literary movement known as the "Harlem Renaissance" (e.g. poet Langston Hughes) and the New York jazz scene (e.g. composer Duke Ellington). In the late 20th century, New York City, and particularly the Bronx, became known as the home of rap/hip-hop music and culture, producing scores of well-known artists like Grandmaster Flash (the Bronx), 
The Notorious B.I.G. (Brooklyn) and Jay-Z (Brooklyn), not to mention Michael Jordan, considered by the NBA to be "the greatest basketball player of all time."

- In the areas surrounding New York City, Italian Americans come to the fore. Their ancestors mostly came from southern Italy in the late 19th and early 20th centuries. Prominent Italian Americans from the New York City area include Supreme Court judges Antonin Scalia and Samuel Alito, New York City mayors Rudolph Giuliani and Bill de Blasio, New York governor Andrew Cuomo, New Jersey governor Chris Christie, filmmaker Martin Scorsese, actors Robert DeNiro, Al Pacino, John Travolta and Sylvester Stallone, and singers Frank Sinatra and Jon Bon Jovi (who is also, incidentally, of Slovak heritage).

Looking at the color-coded ancestry map, as we head west, away from the coast, the Mid-Atlantic states are soon enveloped in a sea of sky blue, representing the country's largest ethnic group: German Americans. Numbering nearly 45 million, German Americans make up approximately 14\% of the US population. And while today they are distributed across the entire country, Pennsylvania is where most of their communities began, and the state continues to be a German American stronghold.

Famous German Americans from the Mid-Atlantic region include baseball legend Babe Ruth (often considered to be the best baseball player of all time), President Donald Trump, actresses Grace Kelly, Meryl Streep and Sandra Bullock, and ketchup magnate Henry J. Heinz.

\subsubsection{Appalachia}

Stretching 2,400 km from eastern Canada all the way to the Southern states of Georgia and Alabama, the Appalachian $\left(/\right.$ ææрə'leI $\left.(\mathrm{t}) \int ə \mathrm{n} /\right)$ Mountains are the largest and most prominent mountain range of eastern North America. 


\section{Northern}

\section{Appalachians \\ (New England)}

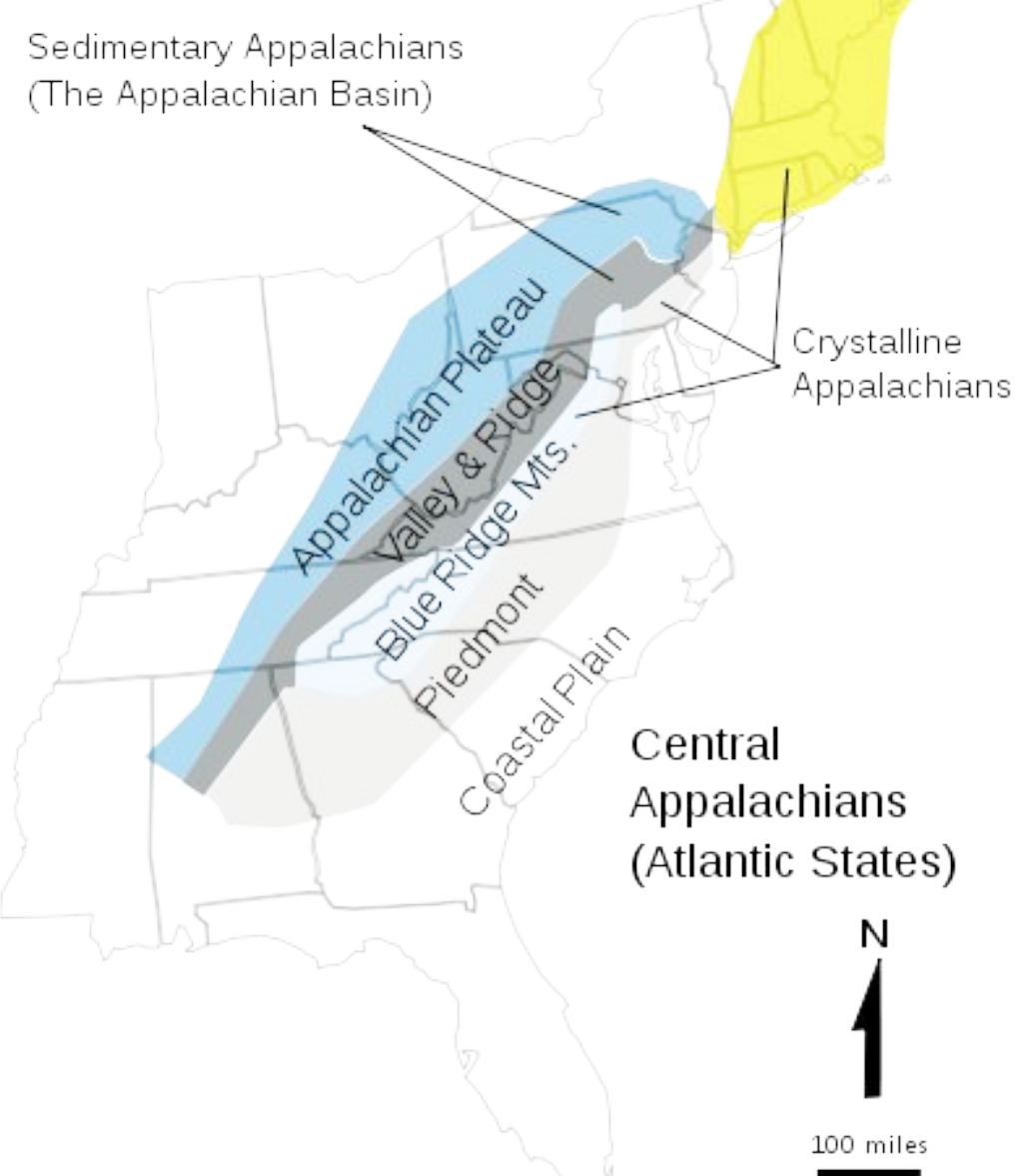

Figure 32: The Appalachian Mountains (Jo Weber, https://commons.wikimedia.org/wiki/File:Appalachian_map.svg, public domain)

A smaller area of the mountain range, seen below in Figure 33, comprises a unique cultural region known as "Appalachia" (/,æpə'lætðə/). Generally considered part of the South, Appalachia nevertheless possesses a distinctive topography, history and culture. 


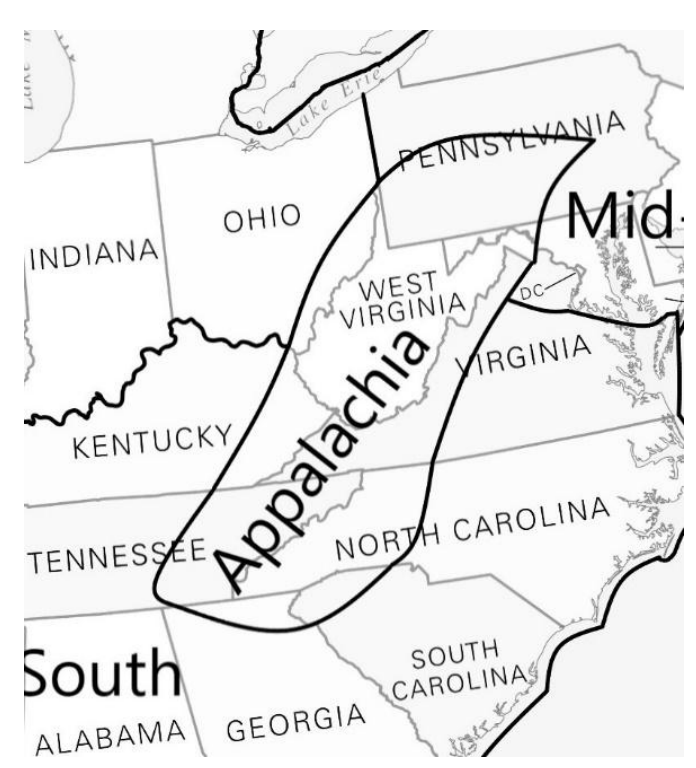

Figure 33: The cultural region of Appalachia

Throughout the colonial period, the mountains of Appalachia formed a natural frontier between the Thirteen Colonies and the Indian territories to the west. Inspired by historian David Hackett Fischer's book Albion's Seed: Four British Folkways in America, journalist Colin Woodard calls the Appalachian settlers and their descendants "the Borderlanders", a fiercely independent people of primarily Scotch-Irish descent. These roots are significant, as the Scotch-Irish have a long history of inhabiting contested border regions, first in the Border Country between England and Scotland, then as Protestant colonizers in what is now Northern Ireland (known as Ulster Scots).

\section{Economy}

With the introduction of railroads in the late 19th century, coal mining expanded enormously in Appalachia, employing the local population as well as an influx of new immigrants from Europe, including Slovakia. This abundant source of energy helped to turn cities such as Pittsburgh, Pennsylvania into major centers of industry. However, the much larger rural parts of the region remained among of the poorest in the country.

\section{Stereotypes}

Appalachia has long been the subject of various, generally negative, stereotypes. The derogatory term "hillbilly", used to refer to the region's residents, has connotations of poverty, willful ignorance, violence and racism. In his controversial memoir Hillbilly Elegy: A Memoir of a Family and Culture in Crisis, investor J. D. Vance presented his life as a story of escape from a dysfunctional culture, exemplifying the social mobility, or "bootstrap" narrative so important in American culture, but also lending credence to some of the negative stereotypes about his home.

Familiar Appalachian stereotypes often intertwine reality with exaggeration, misunderstanding and myth. One example with truth to back it up is "moonshine", the local term for illegally distilled alcohol. Liquor production has long served as a lucrative activity for many in Appalachia, combining the whiskey-distilling traditions of the British Isles with the higher yields of maize, the grain grown by local Indians. When aged in oak barrels until it takes on a brownish amber color, the result is prized Bourbon whiskey, one of the few traditional American products to be strictly regulated in terms of manufacturing and place of origin. Examples include world-famous brands such as Jim Beam and Jack Daniels. At the other end of the spectrum are clear, illegally produced spirits known as moonshine. For obvious reasons, the demand for such moonshine reached a peak during the 1920s Prohibition Era, which coincided with the rise of the automobile (see Henry Ford, p. 74). In Driving with the Devil: Southern Moonshine, Detroit Wheels, and the Birth of NASCAR, author Neal 
Thompson describes how stock car racing (racing with commercially available automobiles as opposed to racecars) and street racing emerged from a tradition of "bootlegging" (moonshine smuggling) using cars, often driven at great speeds down mountain roads and "souped up" (improved) to avoid police and government agents.

On the other hand, like other parts of the South, Appalachia has a strong tradition of conservative, even fundamentalist Christianity. Across the South, this is evidenced by, among other things, the prevalence of "dry counties", where alcohol is banned, many of which date back to the 19th century. Other manifestations of fervent religiosity include snake handling, the use of venomous snakes during church services, sometimes resulting in fatal bites. While this practice is limited to a small number of churches, it has received a great deal of attention, both confirming and perpetuating negative stereotypes of Appalachian culture.

\section{Demographics}

\section{Americans}

Most of the early European settlers in Appalachia came from the British Isles, yet according to the 2000 census, English and Irish Americans don't make up a plurality in many of its counties. Instead, the region is dominated by people who report their ancestry as simply "American". Though their motivations for asserting this identity may vary, we can nevertheless hypothesize about them.

One reason may be the (relatively) long history of European settlement in Appalachia, dating back to the 18th century. Over the centuries, individual nationalities have undoubtedly mixed and family histories have been forgotten. Some people's heritage may be too complicated to sum up in a word; other people may not even know the national origin of their ancestors. Though the descendants of African slaves generally find themselves in a similar position, "African American" is a separate ancestral category, as well as being a visible minority, so we can safely assume that most people who identify as "American" are of primarily European descent.

Identifying oneself as "American" may also be a political statement, expressing a refusal to associate oneself with a subcategory as opposed to a full-fledged American identity.

\section{Cherokees}

Though the Cherokee Indian tribe is native to southern Appalachia, most of its members were forced to migrate west by the Indian Removal Act of 1830, an event known as the Trail of Tears. Nevertheless, a small minority have remained and continue to inhabit far-western North Carolina.

\subsubsection{The South}

Of all the US regions, the South is the one most defined by history, specifically the history of slavery and the Civil War. Slavery's legacy is most apparent in the region's sizable African American population (see Demographics below).

Though the exact borders of the South are not clearly defined, one possible definition is based on the Civil War-era "Mason-Dixon Line", which separated the mostly Confederate "slave states", or "Dixie", from the mostly Unionist "free states", home of the "Yankees". 


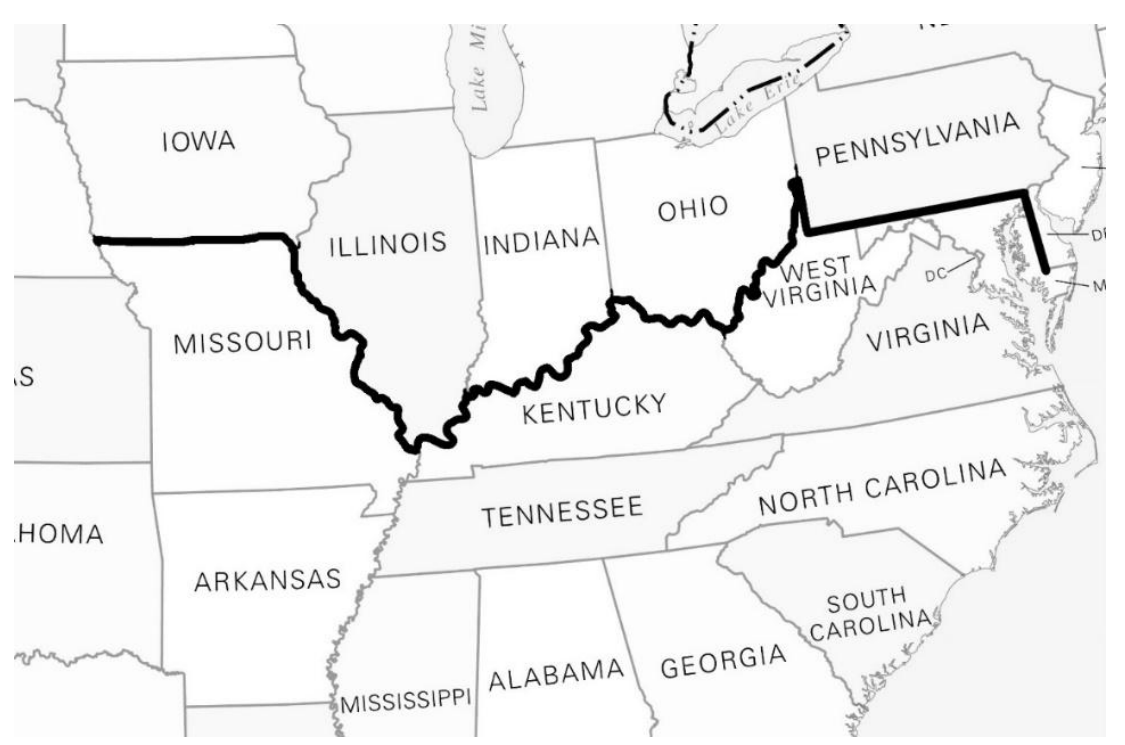

Figure 34: The Mason-Dixon Line

Though 150 years is a very long time from an American perspective, the Civil War and its aftermath continue to influence the South's identity as a region.

The Mississippi state flag, for example, contains the Confederate "battle flag", a symbol of, depending on whom you ask, an interest in history, Southern pride, or racism, even white supremacy.
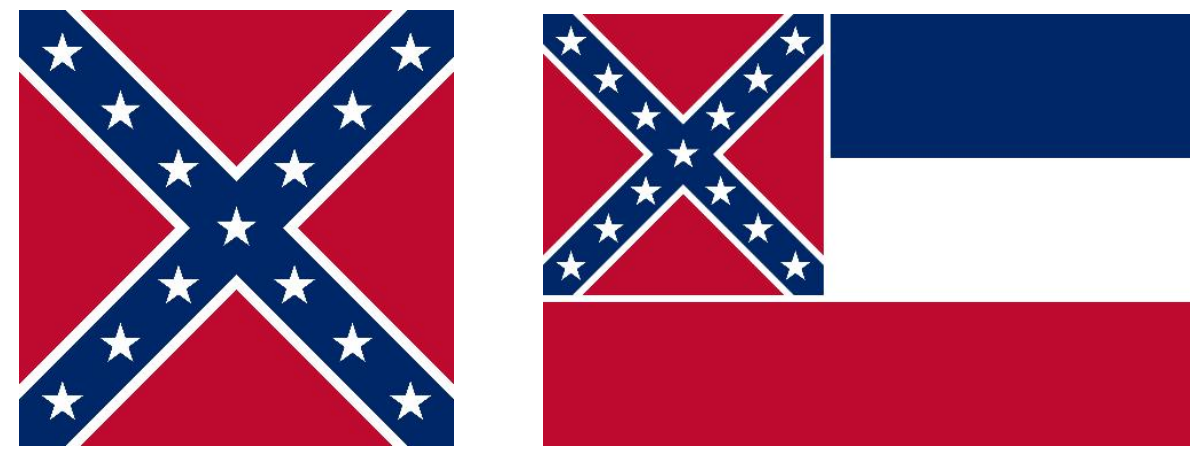

Figure 35: On the right, the Confederate "Battle Flag", originally the flag of the Army of Northern Virginia. On the left, the flag of the state of Mississippi until January 2021 (adopted in 1894, reaffirmed by referendum in 2001). (public domain)

Beyond its historical and political particularities, the South is undoubtedly a culturally distinctive region. The variety of Southern accents are all quite different from standard General American English and generally identify their speakers as being from the South. The richness and variety of Southern cuisine is recognized around the country. Mark Twain, William Faulkner, Flannery O'Conner, Ralph Ellison - the list of great Southern authors is seemingly endless (see p. 105 for more on Southern literature). Through music, from blues, jazz and rock ' $n$ ' roll to bluegrass and country, the South has made an indelible mark not only on American culture, but on the world. And the political influence of the region is evidenced by the fact that the majority of presidents over the last forty years have been from the South, including George H. W. Bush, George W. Bush and Bill Clinton.

\section{Demographics}

Like in Appalachia (generally considered a part of the South), the South is home to an abundance of self-described ethnic "Americans", but the non-Appalachian areas of the South, i.e. the lowlands of "the Deep South", are also inhabited by the US's largest population of African Americans. Students of US history will know why: the Deep South is the area where slave labor was used to grow crops such 
as cotton and tobacco, and for this reason it can be seen as the American homeland of African Americans.

\section{Acadiana}

In the southern part of the state of Louisiana, you will notice a group of counties where French Americans predominate. This unique cultural region, including the area around New Orleans, is known as Acadiana, a reference to Acadia, the French colony in eastern Canada from which most of the Francophone settlers of southern Louisiana came in the 18th century. While most of them identified as "French" in the census, the more common term for this ethnicity is "Cajun". They speak their own dialect of French and continue to practice a variety of distinctive traditions.

The state of Louisiana as a whole has several distinctive features that reveal its French heritage. Instead of being separated into counties like all other US states, Louisiana consists of parishes. Also, its civil court system is based on French Napoleonic law (a system with roots in the Roman legal system) as opposed to Anglo-Saxon common law like the rest of the US.

\section{New Orleans}

While Cajuns are certainly one of the major ethnic groups influencing the unique culture southern Louisiana, they are certainly not the only one. African Americans and Caribbeans have also made major contributions, particularly to New Orleans. The result is a city that holds a singular place in the American imagination. Like many majority-Catholic cultures (including Catholic communities in Slovakia), New Orleans holds an annual pre-Lent Carnival celebration (similar to Slovakia's fašiangy), in this case referred to as Mardi Gras (Fat Tuesday). Since Protestant religious culture dominates most of the rest of the US, Mardi Gras is seen as a unique event. The hometown of jazz, the city also has a rich, living musical heritage.

\subsubsection{Florida}

As evidenced by the 2000 census ancestry map, the Panhandle region of northern Florida is of a piece with the rest of the South. Further south, however, the ethnic makeup of the state diverges into something much more diverse, and these differences speak to a different history and a different culture. For this reason, Florida can be considered a cultural region unto itself.

On one hand, Florida has a very long history of European settlement, home to the US's oldest European-founded municipality: the Spanish colonial city of St. Augustine. During the colonial period, the Spanish, French and British fought for control of various parts of the peninsula, and it was inhabited by a Native American tribes (such as the Seminoles, a mix of local tribes and refugees from conflicts further north), escaped slaves and European settlers. On the other hand, the area south of the Panhandle was sparsely populated until the 20th century. Then, people from other areas of the US, retirees in particular, were attracted by the warm weather (tempered by the invention of air conditioning) and inexpensive living costs. Immigrants from the Caribbean also arrived in large numbers, particularly from Cuba following that country's 1959 revolution. Due to the Communist ideology of the Castro regime, these refugees were generally middle- or upper-class. Many of them settled in Miami, and today they constitute the city's largest ethnicity, contributing to its Caribbeantinged, multicultural, multilingual character.

As a result of these influxes, Florida's population has grown continuously, becoming the third most populous state in 2014. As of 2017, Florida was home to nearly 21 million people.

\subsubsection{The Midwest}




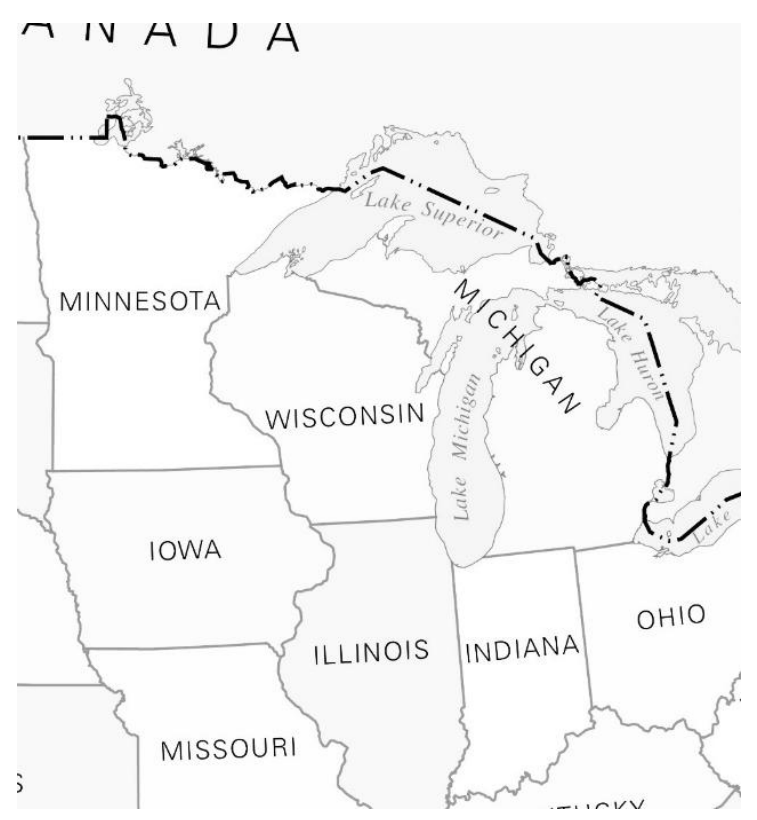

Figure 36: The Midwest

\section{"Middle America", a.k.a. "The Heartland"}

While it once formed the western frontier of the original Thirteen Colonies, the Midwest is now more Mid than West. Often called "Middle America", the Midwest is more than just the US's geographical "Heartland"; it is also widely seen as the most culturally representative, or average, region of the country. Among other things, this is borne out by how people speak. Many Midwesterners are described as having "no accent", due to the fact that their variety of English is closest to General American, the current unmarked form of American English.

\section{"The Breadbasket"}

Thanks to its deep, rich soil, the Midwest is home to a highly productive agricultural industry, earning it the nickname "the Breadbasket". Originally, this referred to wheat, but now Midwestern farms are dominated by the US's two top crops: corn (mainly used for biofuels and animal feed) and soybeans (mainly used for animal feed).

\section{"The Rust Belt"}

Approaching the Great Lakes, Midwestern farmland gives way to a vast industrial region. The network of cities dotting the coasts of the Great Lakes, including Cleveland, Ohio; Detroit, Michigan; and Chicago, Illinois (as well as Windsor, Ontario in Canada) has long manufactured a variety of products. In the 19th century, Cincinnati, Ohio earned the nickname "Porkopolis" thanks to its meatpacking industry, sending barreled pork products such as lard and salt pork down the Ohio River to the Mississippi River. During the Civil War, Chicago usurped the title, aided by its central location in the country's growing railroad network. The city's meatpacking industry is often remembered in infamy thanks to Upton Sinclair's 1906 novel The Jungle, an exposé of the brutal working conditions and lack of proper hygiene which prompted a major public uproar subsequent legislative action, including the founding of what would become the US Food and Drug Administration.

At the turn of the 20th century, the Great Lakes region emerged as the center of the US's nascent automobile industry (see p. 74), which enjoyed its heyday in the 20th century and persists today, despite a downturn during and following the 2008 financial crisis. Also known as "Motor City", Detroit, Michigan is home to the headquarters of the "Big Three" American car manufacturers - Ford, General Motors, and Chrysler (purchased by Fiat in 2014). 
Not only the automobile industry, but also the US's entire manufacturing sector has been in a steady decline since its peak during WWII, leading some to describe this region as "the Rust Belt". During the 2016 presidential elections, a major part of Donald Trump's "Make America Great Again" platform consisted of promises to "restore manufacturing in America."

\section{Chicago}

Home to more than 2.5 million people, Chicago is the US's third largest city by population. It stretches for over 35 kilometers along the shore of Lake Michigan and the banks of the Chicago River, a location that, since the city's founding, has made it a hub for trade routes throughout the North American continent.

Chicago began as fur trading post in the 18th century; by the end of the 19th century, with the help of the railroad, it had become a center of various industries, including meat processing, wood products, clothing, steel and other types of manufacturing. In the early 20th century, Chicago's still-growing industrial economy attracted workers from around the world, including African Americans from the South (see the Great Migration on p. 131), Irishmen and Poles, all of whom continue to have a major presence in the city. To celebrate the Irish holiday St. Patrick's Day, for example, the city dyes the Chicago River a brilliant green.

As its economy grew to include a bustling insurance and financial sector, the downtown area also grew - literally upwards, earning Chicago its reputation as the home of the skyscraper. Built in 1885, the 10-story Home Insurance Building is generally considered to be the world's first skyscraper, but it was dwarfed by later constructions such as the Willis Tower (formerly known as the Sears Tower), which was the tallest building in North America until it was surpassed by New York's One World Trade Center in 2014.

\section{Demographics}

Though they have no Indian reservations today, states like Illinois, Ohio and Indiana (hence the name) were once home to many Native Americans; they were also the sites of bloody wars between the US and various Indian tribes.

As part of New France, the Midwest had been settled by French fur traders since the 17th century, but the first large waves of European American immigration into the area came from the northeast US (New England and Mid-Atlantic, or "Yankees") in the 18th and 19th centuries. They were followed by other European settlers, such as German Americans.

Of particular note are the areas with a preponderance of African Americans - these are the industrial cities mentioned earlier. During the Great Migration (see p. 131) of the early 20th century, black people from the South came to these cities in search of work in the flourishing manufacturing sector as did other ethnicities not visible in this map, such as Irishmen, Italians and Poles - as well as Slovaks.

In what should now be a familiar story, groups of Dutch Protestants seeking religious freedom founded several enclaves in Iowa and Michigan (including the city of Holland, Michigan) which remain to this day, and these communities actively celebrate their Dutch heritage with Netherlandsinspired architecture and annual tulip festivals.

Michigan's Upper Peninsula is different from the rest of the state in several ways - it is separated by the water of Lake Michigan, it is in a different time zone, and it is home to several distinctive ethnic communities, most numerously Finnish Americans, founders of the Lutheran-affiliated Finlandia University.

With its vast forests and numerous lakes, perhaps it is no coincidence that the Upper Midwest (as the northern part of the region is often called) is also home other Scandinavian Americans as well. 
Norwegian Americans, for example, continue to produce and eat lutefisk, an infamously divisive fish dish. Scandinavian languages may have even had an effect on the regional accent (though this theory is not universally held), characterized by a distinctive sing-song intonation and monophthongs in words like "know" [no:] and "same" [se:m]. One public figure with this type of accent is former Alaska governor and 2008 vice-presidential candidate Sarah Palin, who grew up in the MatanuskaSusitna Valley, a part of Alaska settled by people from the Upper Midwest.

\subsubsection{The Great Plains}

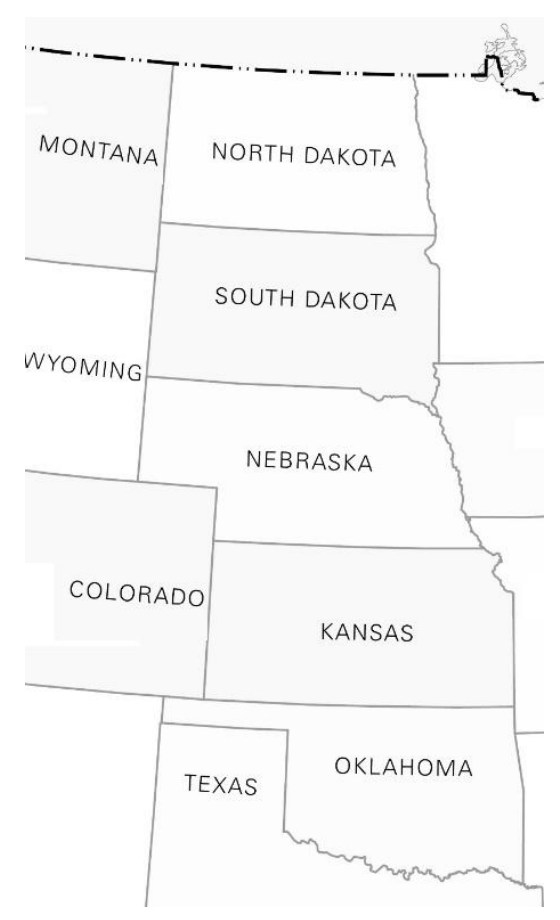

Figure 37: The Great Plains

Though often considered to be a part of the Midwest, the Great Plains is a region that bears many distinctive features, particularly in terms of its natural geography and use of land.

As you travel west from the Mississippi River onwards, the elevation begins to increase imperceptibly, slowly but surely, for over 1000 kilometers, until you reach the foothills of the Rocky Mountains. At its height, this plateau reaches 1800 meters above sea level, despite its flat appearance.

The Great Plains and the states that comprise it are known for their stark natural beauty, sparse population, Native American cultures and extreme weather.

\section{The Prairie}

Much of the Great Plains region consists of a type of grassland called prairie. In the summer, the tall prairie grasses dry and often catch fire, whether by natural causes or human intervention, which prevents trees from growing and is actually essential to the prairie's lifecycle.

\section{"Big Sky Country"}

With its lack of large cities, forests or prominent peaks, the landscape of the Great Plains appears low in comparison to the sky above it, which can feel enormous. For those not used to it, the effect can be downright unsettling at first. 


\section{"Tornado Alley"}

And while this landscape often remains constant for hundreds of miles, the sky above it changes constantly. Thunderstorms are a nearly daily occurrence in the warm season. Even more dangerous, the Great Plains are legendary for their high frequency of destructive tornadoes, earning them the nickname "Tornado Alley". These dangerous weather events necessitate special infrastructure, such as warning sirens and storm cellars, often with a special door on the outside of the house leading directly to its basement. Among the country's most iconic forces of nature, the tornadoes of the Great Plains have been captured onscreen by Hollywood films such as The Wizard of Oz (1939) and Twister (1996).

\section{The Plains Indians}

The Native American peoples of the Great Plains, such as the Cheyenne, the Lakota (historically part of the Sioux), the Cree and the Ojibwe (historically the Chippewa), deserve especial mention due to their outsized influence not only on American culture, but on the perception of Native Americans around the world.

Most stereotypes about Native Americans have their origins among the tribes of the Great Plains in particular. To name a few of these stereotypes:

- Lifestyle: buffalo hunting (many of these tribes were originally nomadic, following herds of buffalo, on which they depended, across the plains), horseback riding

- Crafts: feather headdresses, dreamcatchers

- Housing: teepees (a type of portable dwelling, conducive to a nomadic lifestyle)

- Physique: tall and lanky

It is important to recognize that these are stereotypes, and while they have some basis in truth among the Plains Indians specifically, they certainly cannot be applied to all Native American cultures. Despite that, they have come to represent Native American culture in romanticized popular genres such as westerns, from American productions to Italian-made "spaghetti westerns" and other European works such as Karl May's enormously popular and influential Winnetou novels, as well as their film adaptations. Interestingly, Karl May's works and Winnetou are virtually unknown in the US itself.

\section{The Cherokee Nation (Eastern Oklahoma)}

Not all the Indian tribes currently living in the Great Plains are originally from there. The Cherokee Nation of Oklahoma, currently the US's largest Native American tribe, trace their roots back to the South, from which they, along with members of several other tribes, were expunged by the Indian Removal Act of 1830 in an event known as the Trail of Tears.

\subsubsection{The Rocky Mountains}




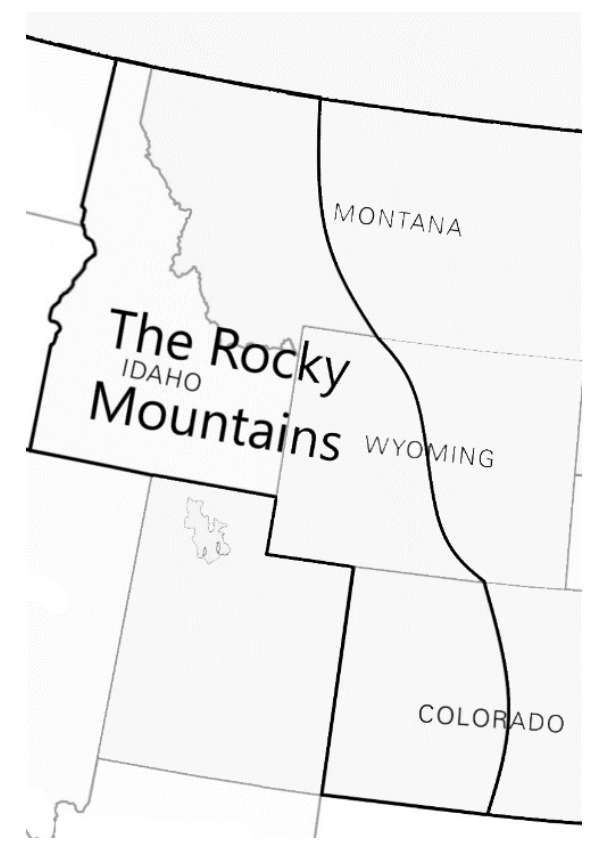

Figure 38: The Rocky Mountain states

As we continue west, despite the already high elevation, they seem to pop up out of nowhere: the Rocky Mountains. Probably North America's best-known mountain range, the Rockies stretch all the way from the Canadian province of British Columbia to the US state of New Mexico. Nevertheless, the states in Figure 38 are the ones most often associated with them.

The vast wildernesses of these states contain more than just majestic mountains; Wyoming's Yellowstone National Park, the world's first, is a veritable garden of geological delights, replete with explosive geysers, pools of mineral-rich water colored otherworldly hues and wondrous rock formations, all surrounding North America's biggest volcano.

"The Rockies", as they are often referred to, have never been an area of dense human settlement. Denver, Colorado, with a population of over 700,000, is the region's largest city by far. Otherwise, the best-known communities are exclusive ski resorts like Aspen, Colorado, and Park City, Utah.

\subsubsection{Texas}

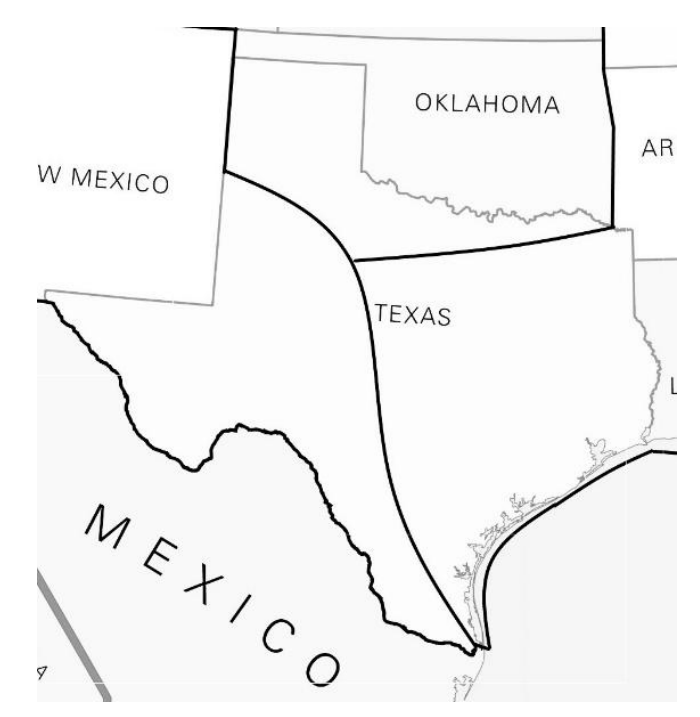

Figure 39: Texas 
Given its great size, unique history and distinctive culture, Texas deserves special treatment. Even if we were to assign it to a particular region, the question would be: which one? The country's secondlargest state straddles three different regions - the South, the Great Plains, and the Southwest - while also constituting a region unto itself.

Though much of Texas is rural, it is also home to some of the US's largest cities. Houston, San Antonio, Dallas, Austin and Fort Worth are all among the country's top 20 municipalities by population. And unlike the big three (New York, Los Angeles and Chicago), they are all growing by more than $10 \%$ annually.

As Texas grows more and more urban, the image of the state remains tied to its rural roots. Cowboy culture has a major presence, including fashion such as cowboy hats, cowboy boots and bolo ties, and sports such as rodeo.

State pride is another area where Texans excel. The state was, after all, its own country for the brief period following the Texas Revolution, and local beer brand Lone Star half-jokingly references this with their slogan, "The National Beer of Texas". The irreverently independent attitude associated with Texans is exemplified by the phrase "Don't Mess with Texas", originally used as an anti-littering campaign by the Texas Department of Transportation.

\subsubsection{0}

\section{The Southwest}

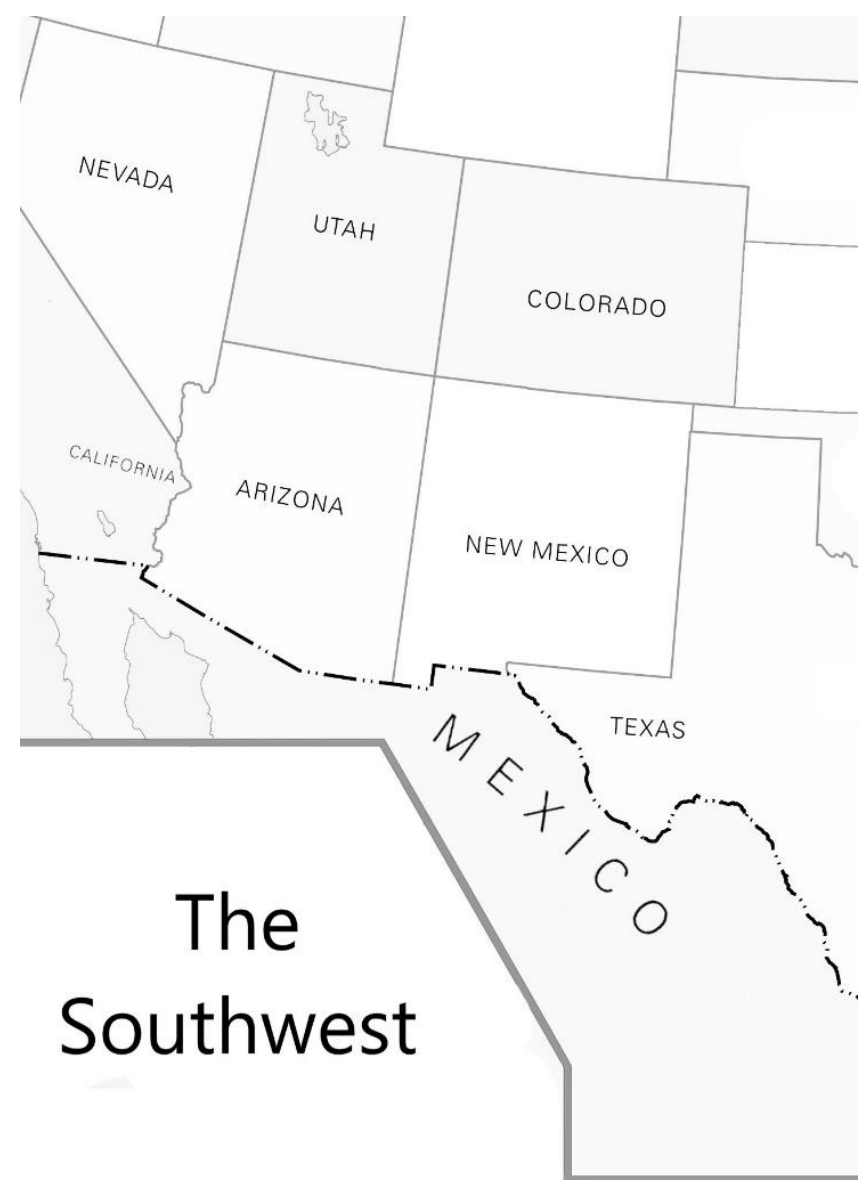

Figure 40: The Southwest

Immortalized in the popular imagination as "the Wild West", the Southwest is a highly distinct region for its natural landscape, history, ethnic composition and culture. Largely composed of desert, it was historically less suitable for dense human settlement, though the same dryness has allowed for the preservation of its long history. The ruins of Anasazi cliff-side villages, for example, date back at least a millennium. 


\section{Demographics}

Today, the Southwest is home to some of the largest Native American communities in the US. The Navajo, for example, number at over 300,000, making them the US's second most populous Native American tribe. What is more, the Navajo language, with nearly 170,000 speakers, is the most widely spoken Native American language in the US. The Navajo Nation is visible in the 2000 Census ancestry map as a cluster of amber counties surrounding the "Four Corners", where the Southwestern states of Arizona, Utah, Colorado and New Mexico meet.

Looking at the same map, the state of Utah stands out from its surroundings, nearly entirely covered by the lavender color representing English Americans. This speaks to the unique origins of one of the US's most homogeneous states, both ethnically and religiously: 67\% of Utah's population are members of the Church of Jesus Christ of Latter-day Saints, also known as Mormons. Mormonism was founded in the 1820s by mystic Joseph Smith in the Anglo-American settlement of Palmyra, New York. After Joseph Smith's death, the Mormon movement, facing continual antagonism from local communities, embarked on a westward "exodus" across the United States and into what was then the Mexican state of Alta California. In the uninhabited Salt Lake Valley, they founded the settlement that would become Salt Lake City, the largest and capital city of Utah.

Utahans' religious values are demonstrated by the differences between their laws and those of their western neighbors, Nevadans. Mormons generally frown on the consumption of alcohol, and Utah's alcohol laws are accordingly restrictive - most shops can only sell beer with $3.2 \%$ alcohol, and bars can only serve drinks until 1:00 am. Cross the border into Nevada, and alcohol is freely available any time of day, while public intoxication is legal (unlike most other US states). What is more, Nevada permits gambling (again, unlike most other US states) and even, in some counties, prostitution (unlike all other US states). Las Vegas, the state's largest city, is known worldwide for its casinos.

While Utah's relatively conservative laws can be chalked up to the influence of Mormonism, what is behind Nevada's comparatively libertine stance? When the Great Depression arrived in the 1930s,

"Victorian values lost the battle with economic reality, and [Las Vegas] found itself perfectly positioned to lure libertine thrill-seekers with money to spend. Booze ran freely, divorce laws were liberalized, prizefights were staged, prostitution was more or less accepted, and, of course, gambling became legal."

\subsubsection{California}




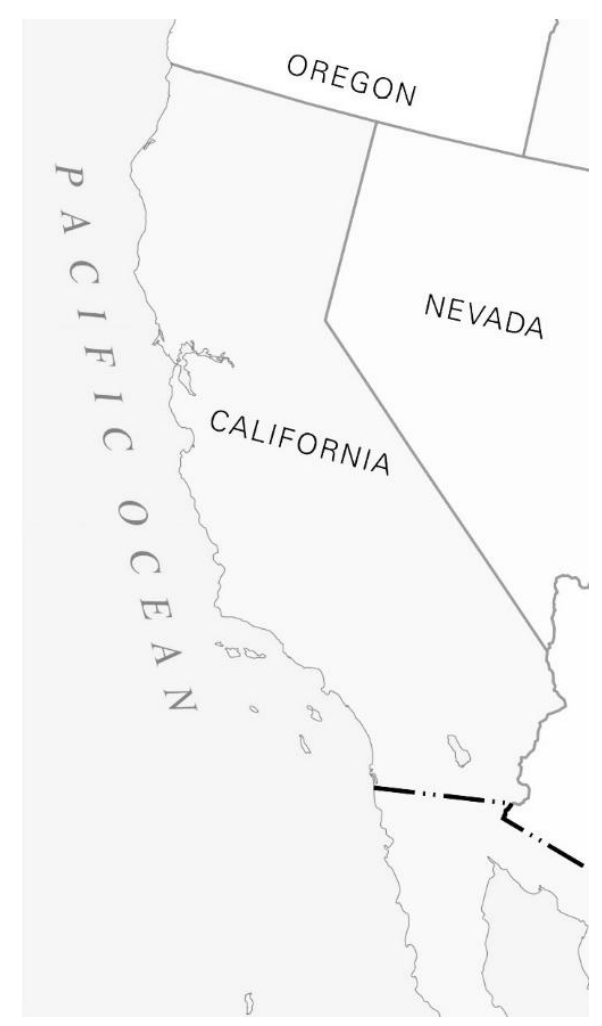

Figure 41: California

California not only overlaps with other regions, it contains areas that are unlike any other part of the country and are as economically, culturally and environmentally significant as they are unique.

\section{The Southern California Coast}

With its mild, Mediterranean weather, picturesque shoreline and Hollywood cachet, the Southern California coast, or "SoCal", is quite literally the stuff of Americans' "California dreams". Exclusive seaside cities like Santa Monica and Santa Barbara are known for their beautiful beaches and Spanish colonial architecture, while larger cities like San Diego and Los Angeles have thriving, diverse economies.

Los Angeles, or "LA", being the US's second-largest city, deserves especial mention. One could even say that its size is outstripped by its influence, home as it is to the US audiovisual entertainment industry, particularly associated with the neighborhood of Hollywood. The US entertainment industry has a global market share of $37 \%$ (and growing); this is a major vehicle, quite possibly the major vehicle of US culture abroad. And since Los Angeles's surroundings are picturesque, varied and most of all conveniently located, many films and television programs are shot and set there as well. This means that people around the world have seen LA, at least onscreen, in classic films such as the film noir Sunset Boulevard (1950), the neo-noir Chinatown (1974), the urban African American drama Boyz $n$ the Hood (1991), the dystopian Philip K. Dick adaptation Blade Runner (1982) and the (relatively) utopian vision of LA in Her (2013), as well as in popular television shows such as Columbo, The Brady Bunch, Beverly Hills, 90210, The Fresh Prince of Bel-Air and many, many more.

Like the Southwest, Los Angeles and the rest of Southern California are also distinguished by the strong presence of Hispanic culture, particularly Mexican culture. After all, this area was part of Mexico until 1848, evidenced by the prevalence of Spanish place-names. What is more, there has been continuous immigration from Mexico since 1848, peaking in 2010. The fact that the people of Los Angeles, regardless of their native language, call themselves "Angelenos", attests to this influence. 


\section{The Central Valley}

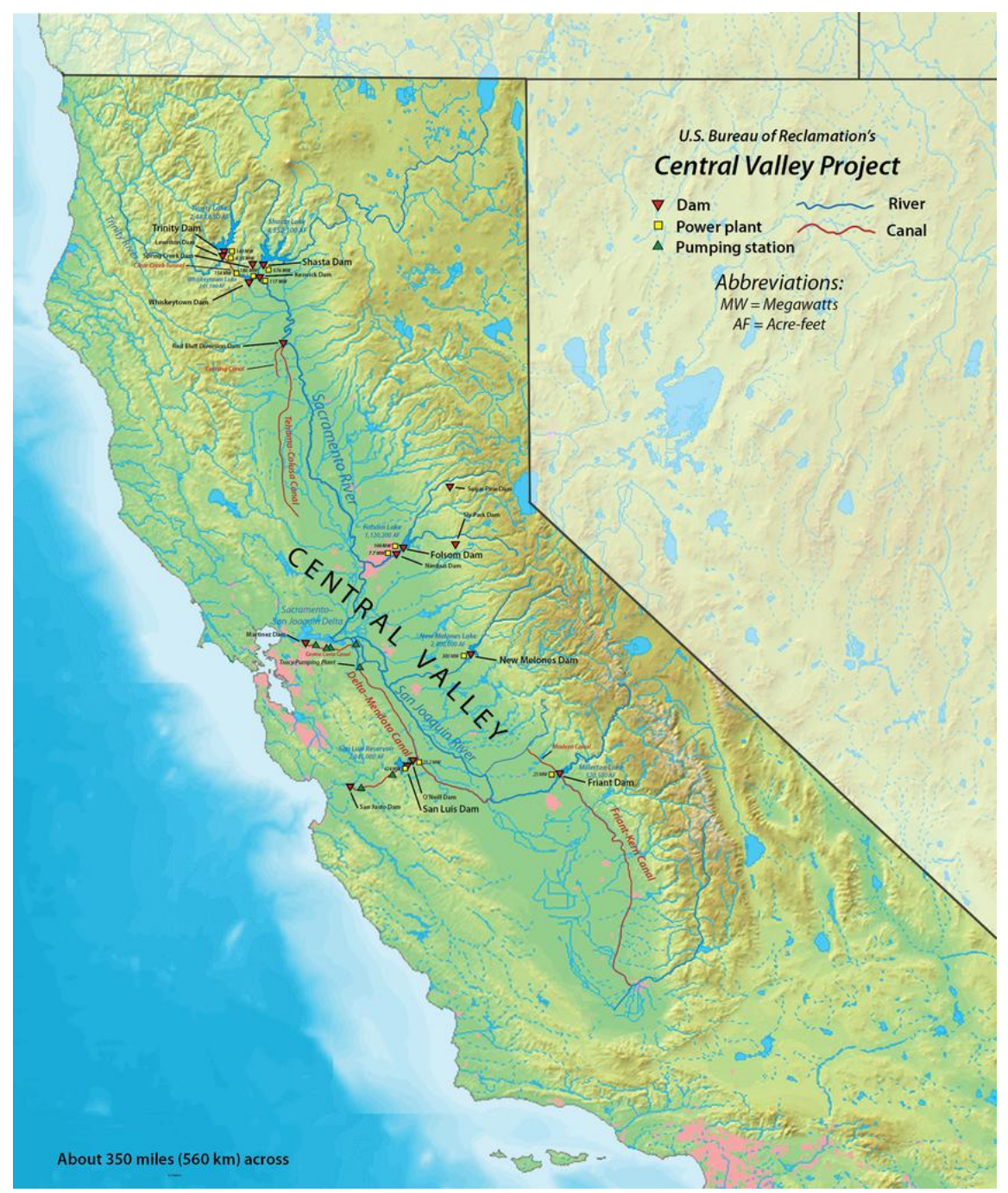

Figure 42: California's Central Valley (Shannon1, https://commons.wikimedia.org/wiki/File:CVP_Map.png, Creative Commons Attribution-Share Alike 4.0 International)

Turning out one third of the country's vegetables, two thirds of its fruits and nuts and about $80 \%$ of the world's almonds, California is the US's most agriculturally productive state, and the Central Valley is California's most productive agricultural region. At nearly $50,000 \mathrm{~km}^{2}$, it is roughly the size of Slovakia. Thanks to its mild climate, long growing season and fertile soil, the region produces an enormous amount of a wide variety of crops.

\section{Silicon Valley}

"I do think that when people look back in a hundred years, they're going to see this as a remarkable time in history. And especially this area, believe it or not."

Steve Jobs, founder of Apple Inc.

Silicon Valley produces "crops" that, while less immediately delicious than the Central Valley's almonds, peaches and oranges, are of no less economic significance. 


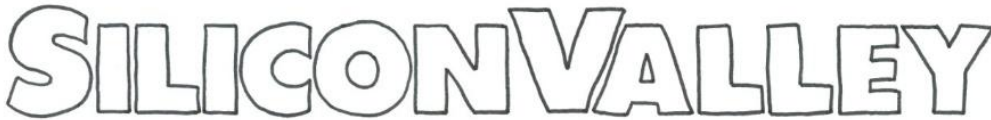 \\ TECH ME TO THE MOON}

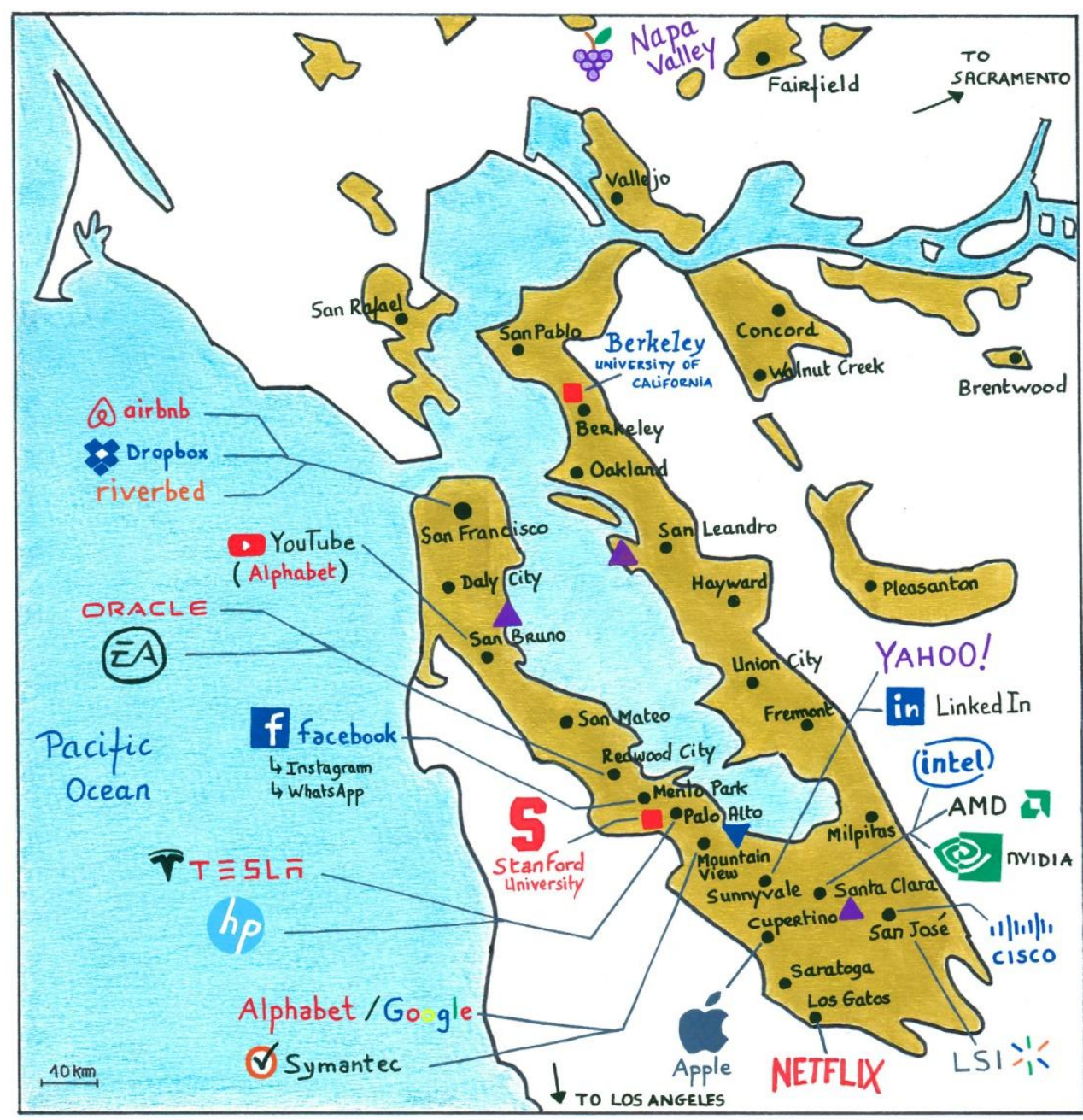

DENSELY POPLLATED URBAN AREAS

NASA AMES RESEARCH CENTER

JUNE 2018
INTERNATIONAL AIRPORTS

LEADING UNIVERSITIES

CHRISTOPHE CHABERT

Figure 43: Silicon Valley and the San Francisco Bay Area (2018, Christophe Chabert, https://mindthemap.fr/siliconvalley/, used with artist's permission)

Silicon is the material used to construct computer microprocessors, and Silicon Valley is indeed home to Intel and AMD, two semiconductor manufacturers which, taken together, represent close to $100 \%$ of the world's PC CPU market.

There is more, however, to Silicon Valley than CPUs. The area south of the San Francisco Bay has been a hotbed of technology since the 1910s, when Lee de Forest, at the Federal Telegraph Company in Palo Alto, invented the vacuum tube, the building block of modern electronics. Today it is the national and global center of the tech industry. Cities like San Jose, Palo Alto and Santa Clara boast the headquarters of globally influential companies including Google, Facebook, Apple, Intel, HP, Adobe, Netflix - the list goes on and on. 
Palo Alto's Stanford University, also known as "the Harvard of the West", has been instrumental to the development of Silicon Valley. The site of the first industrial park, it is the alma mater of such luminaries as William Hewlett and David Packard of Hewlett-Packard (HP) fame, Google founders Larry Page and Sergey Brin, as well as the founders of YouTube, Yahoo!, PayPal, Tesla, LinkedIn, Instagram, and many other companies.

\section{The San Francisco Bay Area}

The Bay Area, as it is often called, is one of the most desirable places to live in the US, including the aforementioned Silicon Valley, as well as cities such as Oakland, Berkeley and its namesake San Francisco.

With a whopping average rent of over $\$ 3,200$ per month for a one-bedroom apartment as of 2020, San Francisco is the world's second most expensive city to rent an apartment in after Hong Kong. The possible reasons for this are many. Famous as a center of hippie culture in the 1960s and known for its dramatic hills, magnificent parks and magnolia-lined streets, San Francisco's appeal is undeniable. First of all, however, it was the California Gold Rush of 1849 that turned San Francisco into the first major US city on the West Coast. This comparatively early start, along with its restricted location (at the tip of a peninsula in the San Francisco Bay), encouraged urban development of a density unparalleled in the western United States. The population density is matched by a dense public transportation network, and the convenient lifestyle this allows for makes San Francisco a highly appealing place to live for people throughout the Bay Area, including Silicon Valley.

San Francisco is also home to the oldest and proportionally largest Chinese community in the US; in fact, Chinese American is the city's leading ancestry according to the 2000 census. Along with its Chinatown neighborhood, San Francisco is well known for its Japantown district. This fact exemplifies a larger phenomenon across the West Coast: the major influence of immigration from East Asia dating back to the early 19th century. Among the famous Chinese Americans from the Bay Area are novelist Amy Tan and actor/martial artist Bruce Lee, while famous Japanese Americans from the area include actor/activist George Takei and physicist Michio Kaku.

\subsubsection{The Pacific Northwest}

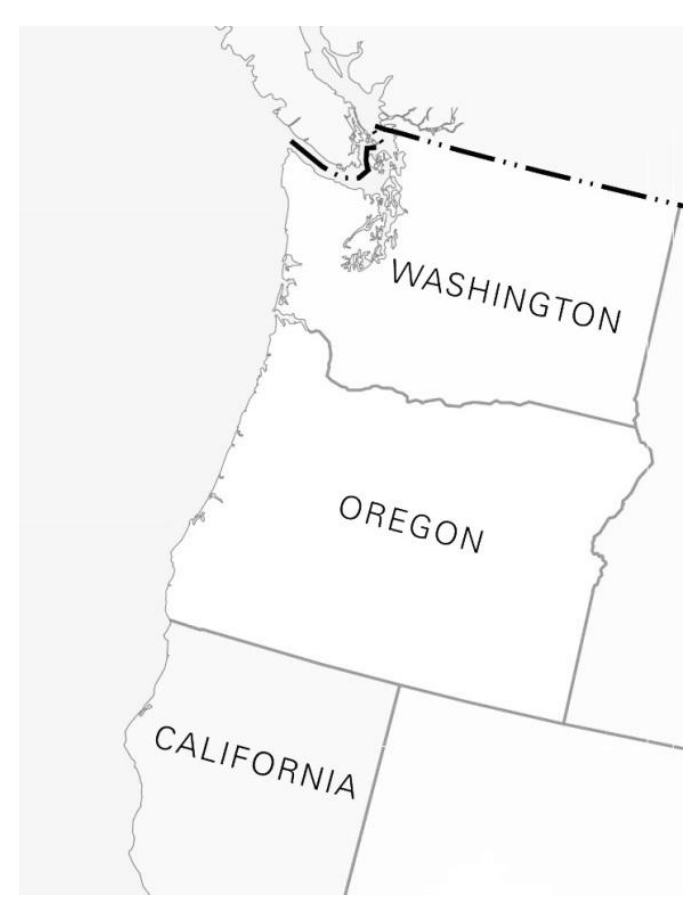

Figure 44: The US portion of the Pacific Northwest 
The Pacific Northwest is a geographical and cultural region that transcends state, and by some measures, national borders, stretching along the Pacific coast from Northern California and the US states of Oregon and Washington, through the Canadian province of British Columbia, all the way to Alaska.

This vast region is unified by natural traits such as mild, moist weather, volcanic mountain ranges and temperate rainforests (including the California Redwood, the world's tallest tree species), as well as cultural traits like similar indigenous cultures and a liberal political culture, at least in the region's cities, which include Vancouver, British Columbia; Portland, Oregon; and Seattle, Washington.

While Silicon Valley may reign supreme as the US's tech hub, a strong case for second place can be made for Seattle, thanks to the presence of Microsoft and Amazon, as well as that of the gaming giant Valve Corporation.

Seattleites' coffeeshop culture has been exported worldwide via once-local chain Starbucks. The city also made a name for itself as the center of the 1990s grunge scene, associated with bands such as Nirvana, Pearl Jam and Alice in Chains. And as the original home of Boeing, the world's biggest aerospace company, Seattle is a major player in the defense industry as well.

12.3.13

Alaska

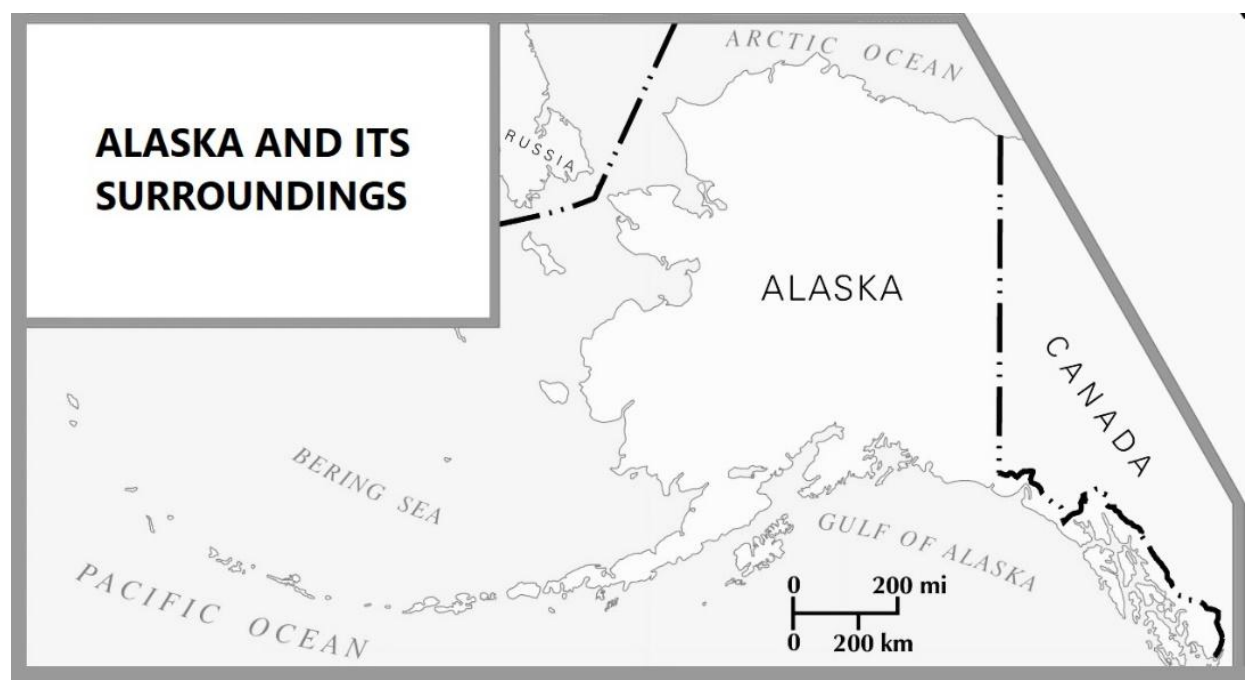

Figure 45: Alaska

At over 1.7 million $\mathrm{km}^{2}$, Alaska is by far the largest US state by geographical size. For this reason, along with its geographical separation from the rest of the country, the state clearly deserves to be treated as its own region.

Alaska's superlatives are not limited to its geographical size; it is also home to the US's highest peak, Denali (6,190 m, known as Mount McKinley until 2015), its largest protected area, the Arctic National Wildlife Refuge $\left(78,000 \mathrm{~km}^{2}\right.$, the size of the Czech Republic), and the largest oil field in North America (Prudhoe Bay Oil Field).

It is no exaggeration to call fossil fuels the lifeblood of Alaska's economy, making up $90 \%$ of the state's revenue, from which between $\$ 1,000$ and $\$ 2,000$ is annually given back to each state resident, in a form of "universal basic income" or "reverse tax" (Alaska has no state income tax or sales tax). Nevertheless, some of its reserves remain untouched, as they lie under protected land, such as the Arctic National Wildlife Refuge. Oil drilling on the Arctic Refuge was a hotly debated topic nationally for decades, until Congress finally opened it up for drilling in 2017.

Despite its low population (less than 750,000 people), Alaska is inhabited by a variety of ethnicities, particularly indigenous peoples, who make up over $15 \%$ of the population, the highest proportion in 
the US. Many of Alaska's native people identify as Inuit (sometimes referred to as "Eskimos"), a group of ethnicities living throughout the Arctic regions of the Western Hemisphere. The Inuit are known for their ability to thrive in harsh arctic conditions, particularly their traditional use of sleds drawn by huskies, the dog breed raised specifically for that purpose, and hunting of marine mammals, such as seals and whales.

\subsubsection{Hawaii}

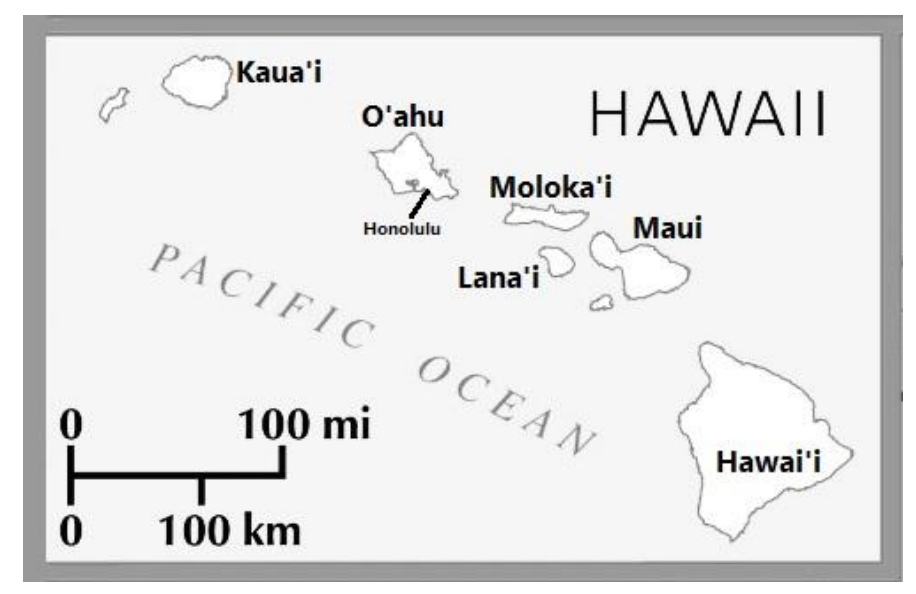

Figure 46: Hawaii

Hawaii, or Hawai $i$ in the Hawaiian language, is a long archipelago, a chain of 137 islands stretching 2,400 kilometers across the Pacific Ocean. Due to their small size, however, most of these islands are unpopulated. The six islands labeled in Figure 46 are the only ones with significant human populations.

The Hawaiian Islands have been home to the Polynesian Hawaiian people for nearly two millennia. The youngest US state, Hawaii was a constitutional monarchy until 1893, when Queen Lili'uokalani was ousted by US nationals. After a few years as an independent republic, Hawaii was annexed by the US in 1898, acquiring the status of US territory until 1959, when it became a full-fledged state.

In 2000 , Native Hawaiians made up $6.6 \%$ of the population, greatly outnumbered by the descendants of later-arriving immigrants such as Japanese (17\%), Filipino (14\%) and white Americans (24\%). Japanese culture in particular has made its mark on Hawaiian culture, one example being the "Aloha shirt", an item of men's formalwear that began in the 1910s as a button-up shirt sewn from Japanese patterned kimono fabrics. Today, aloha shirts bear patterns that reflect native Hawaiian flora and fauna. In the 1960s, Hawaiian businessmen began wearing Aloha shirts instead of conventional suits on Friday, in a custom known as "Aloha Friday". By the 1990s, this custom of wearing less formal clothing to work on Fridays had spread across the US and beyond, where it is now known as "Casual Friday".

Another item of traditional Hawaiian clothing now recognized and worn worldwide is the loosefitting women's dress known as the muu-muu. 


\section{Follow-up}

1. Name two distinctive features of each US region.

2. Examine the "Largest Ancestry" map from the 2010 US Census. What patterns do you see? How do they correspond to the borders of states or various unofficial regions? What peoples' stories do you see represented in the map? What is the story behind...

a. the distribution of African Americans, both in the South and in cities further north?

b. the French populations in the Northeast as well as southern Louisiana?

c. Irish Americans, particularly in the Northeast?

e. German Americans, who appear to dominate nearly everywhere?

f. the English American population throughout Utah?

g. various other, smaller ethnic enclaves, e.g. Norwegians, Chinese, Cubans, Japanese, Portuguese, Filipino etc.?

h. Where do you see the largest Native American populations? Do you know which specific tribes or nations these areas represent? 


\section{Appendix A The US Anthem}

The Star-Spangled Banner by Francis Scott Key, 1814

1

Oh, say can you see by the dawn's early light

What so proudly we hailed at the twilight's last gleaming?

Whose broad stripes and bright stars thru the perilous fight,

O'er the ramparts we watched were so gallantly streaming?

And the rockets' red glare, the bombs bursting in air,

Gave proof through the night that our flag was still there.

$\mathrm{Oh}$, say does that star-spangled banner yet wave

O'er the land of the free and the home of the brave?

On the shore, dimly seen through the mists of the deep,

Where the foe's haughty host in dread silence reposes,

What is that which the breeze, o'er the towering steep,

As it fitfully blows, half conceals, half discloses?

Now it catches the gleam of the morning's first beam,

In full glory reflected now shines in the stream:

'Tis the star-spangled banner! Oh long may it wave

O'er the land of the free and the home of the brave!

And where is that band who so vauntingly swore That the havoc of war and the battle's confusion, A home and a country should leave us no more!

Their blood has washed out their foul footsteps' pollution.

No refuge could save the hireling and slave

From the terror of flight, or the gloom of the grave:

And the star-spangled banner in triumph doth wave

O'er the land of the free and the home of the brave!

Oh! thus be it ever, when freemen shall stand

Between their loved home and the war's desolation!

Blest with victory and peace, may the heav'n rescued land Praise the Power that hath made and preserved us a nation.

Then conquer we must, when our cause it is just,

And this be our motto: "In God is our trust."

And the star-spangled banner in triumph shall wave

O'er the land of the free and the home of the brave!

\section{Appendix B US States, Capitals, Nicknames and the Etymology of Selected State Names}

State Capital Nickname

Alabama Montgomery Yellowhammer State 


\begin{tabular}{|c|c|c|}
\hline Alaska & Juneau & The Last Frontier \\
\hline Arizona & Phoenix & The Grand Canyon State \\
\hline Arkansas & Little Rock & The Natural State \\
\hline California & Sacramento & The Golden State \\
\hline Colorado & Denver & The Centennial State \\
\hline Connecticut & Hartford & The Constitution State \\
\hline Delaware & Dover & The First State \\
\hline Florida & Tallahassee & The Sunshine State \\
\hline Georgia & Atlanta & The Peach State \\
\hline Hawaii & Honolulu & The Aloha State \\
\hline Idaho & Boise & The Gem State \\
\hline Illinois & Springfield & Land of Lincoln \\
\hline Indiana & Indianapolis & The Hoosier State \\
\hline Iowa & Des Moines & The Hawkeye State \\
\hline Kansas & Topeka & The Sunflower State \\
\hline Kentucky & Frankfort & The Bluegrass State \\
\hline Louisiana & Baton Rouge & The Pelican State \\
\hline Maine & Augusta & The Pine Tree State \\
\hline Maryland & Annapolis & The Old Line State \\
\hline Massachusett & Boston & The Bay State \\
\hline
\end{tabular}




\begin{tabular}{|c|c|c|}
\hline Michigan & Lansing & The Great Lakes State \\
\hline Minnesota & St. Paul & The North Star State \\
\hline Mississippi & Jackson & The Magnolia State \\
\hline Missouri & Jefferson City & The Show Me State \\
\hline Montana & Helena & The Treasure State \\
\hline Nebraska & Lincoln & The Cornhusker State \\
\hline Nevada & Carson City & The Silver State \\
\hline New Hampshire & Concord & The Granite State \\
\hline New Jersey & Trenton & The Garden State \\
\hline New Mexico & Santa Fe & The Land of Enchantment \\
\hline New York & Albany & The Empire State \\
\hline North Carolina & Raleigh & The Tar Heel State \\
\hline North Dakota & Bismarck & The Peace Garden State \\
\hline Ohio & Columbus & The Buckeye State \\
\hline Oklahoma & Oklahoma City & The Sooner State \\
\hline Oregon & Salem & The Beaver State \\
\hline Pennsylvania & Harrisburg & The Keystone State \\
\hline Rhode Island & Providence & The Ocean State \\
\hline South Carolina & Columbia & The Palmetto State \\
\hline
\end{tabular}

South Dakota Pierre Mount Rushmore State 


$\begin{array}{lll}\text { Tennessee } & \text { Nashville } & \text { The Volunteer State } \\ \text { Texas } & \text { Austin } & \text { The Lone Star State } \\ \text { Utah } & \text { Salt Lake City } & \text { The Beehive State } \\ \text { Vermont } & \text { Montpelier } & \text { The Green Mountain State } \\ \text { Virginia } & \text { Richmond } & \text { The Old Dominion State } \\ \text { Washington } & \text { Olympia } & \text { The Evergreen State } \\ \text { West Virginia } & \text { Charleston } & \text { The Mountain State } \\ \text { Wisconsin } & \text { Madison } & \text { The Badger State } \\ \text { Wyoming } & \text { Cheyenne } & \begin{array}{l}\text { The Equality or Cowboy } \\ \text { State }\end{array}\end{array}$

Names of American states tell a story. Some of them adopted an altered version of their original Indian name, some adopted, in a more colonial fashion, a name after its first explorers or colonizers. For example:

\begin{tabular}{|l|l|l|}
\hline $\begin{array}{l}\text { State names of Indian } \\
\text { origin: }\end{array}$ & French origin: & Spanish origin: \\
\hline $\begin{array}{l}\text { Alaska, Arkansas, } \\
\text { Connecticut, } \\
\text { Massachusetts, Nebraska, } \\
\text { Oklahoma }\end{array}$ & Vermont, Oregon & $\begin{array}{l}\text { California, Montana, } \\
\text { Nevada }\end{array}$ \\
\hline
\end{tabular}

With the help of the internet or a dictionary, determine the etymological origin of the following states and complete the table above: Indiana, Minnesota, Mississippi, Oklahoma, Utah, Vermont, Florida, Colorado, Delaware. Can you guess the history of these states?

Some American states were named after a king, queen or a famous person, For example: Louisiana was named after the French king Louis XIV. Can you guess which of the following US states was named after a queen, king or a famous person? 
- Maryland

- New York
- South and North Carolina

- Virginia

3. Each American state has a state nickname that reflects its history, early inhabitants, flora, fauna, way of life, main crops, climate or eccentricity etc. For example: Florida is nicknamed "The Sunshine State" because it has a very warm and sunny climate. Can you guess which US states are nicknamed:

1. The Aloha State

2. The Bluegrass State

3. The Empire State of the South

4. The Grand Canyon State

5. The Lone Star State a) Georgia

b) Texas

c) Kentucky

d) Hawaii

e) Arizona

\section{Appendix C I Have a Dream (extract)}

By the Rev. Martin Luther King Jr.

August 28, 1963

1 I am happy to join with you today in what will go down in history as the greatest demonstration for freedom in the history of our nation.

2 Five score years ago, a great American, in whose symbolic shadow we stand today, signed the Emancipation Proclamation. This momentous decree came as a great beacon light of hope to millions of Negro slaves who had been seared in the flames of withering injustice. It came as a joyous daybreak to end the long night of their captivity.

3 But one hundred years later, the Negro still is not free. One hundred years later, the life of the Negro is still sadly crippled by the manacles of segregation and the chains of discrimination. One hundred years later, the Negro lives on a lonely island of poverty in the midst of a vast ocean of material prosperity. One hundred years later, the Negro is still languished in the corners of American society and finds himself an exile in his own land. And so we've come here today to dramatize a shameful condition.

4 In a sense we've come to our nation's capital to cash a check. When the architects of our republic wrote the magnificent words of the Constitution and the Declaration of Independence, they were signing a promissory note to which every American was to fall heir. This note was a promise that all men, yes, black men as well as white men, would be guaranteed the "unalienable Rights" of "Life, Liberty and the pursuit of Happiness." It is obvious today that America has defaulted on this promissory note, insofar as her citizens of color are concerned. Instead of 
honouring this sacred obligation, America has given the Negro people a bad check, a check which has come back marked "insufficient funds."

5 But we refuse to believe that the bank of justice is bankrupt. We refuse to believe that there are insufficient funds in the great vaults of opportunity of this nation. And so, we've come to cash this check, a check that will give us upon demand the riches of freedom and the security of justice.

We have also come to this hallowed spot to remind America of the fierce urgency of Now. This is no time to engage in the luxury of cooling off or to take the tranquilizing drug of gradualism. Now is the time to make real the promises of democracy. Now is the time to rise from the dark and desolate valley of segregation to the sunlit path of racial justice. Now is the time to lift our nation from the quicksands of racial injustice to the solid rock of brotherhood. Now is the time to make justice a reality for all of God's children.

7 It would be fatal for the nation to overlook the urgency of the moment. This sweltering summer of the Negro's legitimate discontent will not pass until there is an invigorating autumn of freedom and equality. Nineteen sixty-three is not an end, but a beginning. And those who hope that the Negro needed to blow off steam and will now be content will have a rude awakening if the nation returns to business as usual. And there will be neither rest nor tranquility in America until the Negro is granted his citizenship rights. The whirlwinds of revolt will continue to shake the foundations of our nation until the bright day of justice emerges.

But there is something that I must say to my people, who stand on the warm threshold which leads into the palace of justice: In the process of gaining our rightful place, we must not be guilty of wrongful deeds. Let us not seek to satisfy our thirst for freedom by drinking from the cup of bitterness and hatred. We must forever conduct our struggle on the high plane of dignity and discipline. We must not allow our creative protest to degenerate into physical violence. Again and again, we must rise to the majestic heights of meeting physical force with soul force.

The marvelous new militancy which has engulfed the Negro community must not lead us to a distrust of all white people, for many of our white brothers, as evidenced by their presence here today, have come to realize that their destiny is tied up with our destiny. And they have come to realize that their freedom is inextricably bound to our freedom.

We cannot walk alone.

And as we walk, we must make the pledge that we shall always march ahead.

We cannot turn back.

10 There are those who are asking the devotees of civil rights, "When will you be satisfied?" We can never be satisfied as long as the Negro is the victim of the unspeakable horrors of police brutality. We can never be satisfied as long as our bodies, heavy with the fatigue of travel, cannot gain lodging in the motels of the highways and the hotels of the cities. 
11 We cannot be satisfied as long as a Negro in Mississippi cannot vote and a Negro in New York believes he has nothing for which to vote. No, no, we are not satisfied, and we will not be satisfied until "justice rolls down like waters, and righteousness like a mighty stream." "

12 I am not unmindful that some of you have come here out of great trials and tribulations. Some of you have come fresh from narrow jail cells. And some of you have come from areas where your quest for freedom left you battered by the storms of persecution and staggered by the winds of police brutality. You have been the veterans of creative suffering. Continue to work with the faith that unearned suffering is redemptive. Go back to Mississippi, go back to Alabama, go back to South Carolina, go back to Georgia, go back to Louisiana, go back to the slums and ghettos of our northern cities, knowing that somehow this situation can and will be changed.

Let us not wallow in the valley of despair, I say to you today, my friends.

And so even though we face the difficulties of today and tomorrow, I still

13 have a dream. It is a dream deeply rooted in the American dream.

I have a dream that one day this nation will rise up and live out the true

14 meaning of its creed: "We hold these truths to be self-evident, that all men are created equal."

I have a dream that one day on the red hills of Georgia, the sons of former

15 slaves and the sons of former slave owners will be able to sit down together at the table of brotherhood.

I have a dream that one day even the state of Mississippi, a state

16 sweltering with the heat of injustice, sweltering with the heat of oppression, will be transformed into an oasis of freedom and justice.

I have a dream that my four little children will one day live in a nation

17 where they will not be judged by the color of their skin but by the content of their character.

I have a dream today!

I have a dream that one day, down in Alabama, with its vicious racists,

18 with its governor having his lips dripping with the words of "interposition" and "nullification" -- one day right there in Alabama little black boys and black girls will be able to join hands with little white boys and white girls as sisters and brothers.

I have a dream today!

19 I have a dream that one day every valley shall be exalted, and every hill and mountain shall be made low, the rough places will be made plain, and the crooked places will be made straight; "and the glory of the Lord shall be revealed and all flesh shall see it together."

This is our hope, and this is the faith that I go back to the South with.

(End of extract; read full text at

http://www.miamiherald.com/2013/08/24/3580335_p2/full-text-ofmartin-luther-king.html) 


\section{Appendix D Sample Essay in American Studies}

Read the following sample essay in American studies:

Title

Student's

name, year

and course of

study

Date due

1 st sentence-

connects with

the reader

2nd sent. -

gives examples

$3^{r d}$ sent. -

THESIS =

main

organizational sentence of an essay

Development of arguments: Argument 1:

Illustrational direct quote: if longer, use smaller print and indents.

Reference: Intext citation (name, page).

\section{Is the Second Amendment to the Constitution an Outmoded Practice?}

\author{
Ol'ga Nováková \\ Katedra anglistiky a amerikanistiky, \\ 2nd year; UAP, English - French
}

Due: May 30, 2019

Individual citizens very often face situations when they have to defend their civil rights and liberties. Examples of these might be crimes such as burglary or hold-up. In spite of the fact that these situations are likely to happen, the right of people to bear and keep arms should be limited. Otherwise, citizens might be prone to a subjective understanding of carrying out laws, weapons might be abused or misused by children and crime rate might rapidly increase.

The dangers of subjective understanding and enforcement of laws lie in the fact that a vast majority of people are not competent to justly and objectively interpret laws. Only courts and judges are authorized to explain laws and apply them to individual cases. An example of incompetent interpretation and execution of laws was the well-known legal case Goetz $v$. State in the 1980s:

...New York subway passenger Bernhard Goetz took the law into his own hands to avoid being the victim of another crime, he was hailed a hero by most New Yorkers. The incident occurred in 1984 on a subway train when four youths demanded five dollars of him. Goetz, a man with no criminal record who had already been mugged and beaten several months earlier, reacted by pulling out a gun and shooting the four youths, all of whom had criminal records, including conviction for armed robbery and burglary. In a three-month trial in 1987 Goetz was finally acquitted of all but the relatively minor charge of illegally possessing a gun (Fiedler, p. 102).

Although some might feel Goetz has a sort of "eye for an eye" right to defend his life and property, it was his individual decision to pull out the gun that killed or seriously injured four 
Your analysis of the quote:

Argument 2:

Argument 3: people, regardless of their potential motivation or their reasons for committing the robbery. In addition, the robbery was de facto legally classified a misdemeanor (Crane, p. 65) all that the youths demanded before they were shot was five dollars. Thus the youths actually had their lives taken for a very banal fault or, rather, what could have been just a teenage lapse.

The danger of the fact that an individual decision might result in an execution of a citizen must not be played down for one more historical reason - it was the same kind of individual or small-and-incompetent-group-based decision that led to the "lynching" trials at the end of the 19th century in the USA. Both such decisions (lynching and individual execution) tend to be subjective and based on previous experience, current mental state or even mood of the person who pulls the trigger. History supplies many examples of hasty enforcement of laws, which very often resulted in legal error.

To sum up, the criminal history of the youths does not supply enough information about their moral character or motivation. To Bernhard Goetz, they were obviously inner-city slum teenagers harassing commuters in the subway. However, their participation in the harassment might have varied; some of them might have been only on-lookers. Needless to say, many innocent people could have been injured during the shooting as well.

The question to what extent Goetz's decision was influenced by the fact that he was carrying a gun is of a philosophical nature. If he had not had a gun, he might have been robbed or even killed by the youths. Nevertheless, his defense of his own life at the cost of four other lives certainly provokes many questions about validity of the Second Amendment to the Constitution and free ownership and purchase of guns by the general public.

Free sale and ownership of guns could also result in weapon abuse, because it makes guns accessible not only to their competent and trained owners but possibly also to children and criminals. Many real-life situations have proved that no matter how strictly ordinances regulate keeping or storing guns, there is always a possibility of their abuse. Children could accidentally find them in the house and criminals could simply steal them. Moreover, unless there is federal registration of arms (Allen, p. 165), many guns could be abused for crimes without a chance to bring them back to their owners.

Free and unrestricted ownership of guns could also provoke many felonies such as gun threats, which would be unlikely to happen otherwise. This is because the decision of when and how to use gun would lie exclusively on its owner, instead of on legislative representatives. The example of two schoolboys 
Argument 4: $\quad$ who first threatened and then shot twelve of their schoolmates illustrates another effect of this constitutional right:

Direct quote supporting Argument 4:

Analysis of the quote:

Conclusion:

\section{Final} statement stating why is the topic important nowadays:

Alphabetically ordered works cited entries:
In November 1999, two thirteen-year-old schoolboys shot twelve students of the high school they were studying at. The gun was under legal ownership of one of the boys' parent, who "did not even realize it was missing." When asked about their reasons for shooting, both boys said they wanted to punish a schoolboy who harassed them. Unable to find him, they started shooting into the crowd of students, going home from school (Werner, p. 21).

This case proves not only how easy it can be to obtain a gun, but also that the decision when and how to use a gun might be based on an individual's mental state or even mood.

It is my opinion that free purchase and ownership of guns leads to gun misuse and abuse. Therefore the Second Amendment to the Constitution, which suggests that gun ownership is one of Americans' fundamental rights, should be changed or amended, and the right of people to "keep and bear arms" should be infringed upon through regulations preventing gun abuse. Society's safety cannot rely upon the momentarily decisions of individuals, but on solid rules and laws that control the basic civil rights of individuals.

\section{Works Cited}

ALLEN, B. 1993. American Belief. New York: Hill Road Publishing, 1993. pp. 308. ISBN 023-568-9985-X.

CRANE, S. 1995. Modern History of the USA. Yale: Yale University Press, 1995. pp. 546. ISBN 895-254-465.

FIEDLER, E. 1990. American Society. New York: Litton Editorial Publishing, 1990. pp. 514. ISBN 0-278-46072-0.

WERNER, K. 2000. Was Goetz Right? In Newsweek. March 4, 2000, No. 3. pp. 16-17. In: http://www.wasgoetzright?newsweek.march4.2000.com/. [Accessed: April 2, 2019]. 


\section{Works Cited}

ACHEBE, C. 2001. Interview by Jason Zasky. Failure, Apr. 7, 2001. In:

http://failuremag.com/article/chinua-achebe. [Accessed August 10, 2021].

AGNEW, R.-MOYER, D. 1999. Population Distribution: Where do we live? Where don't we live? In: WURMAN, R. S. Understanding USA. Newport, RI: TED Conferences.

ALASKA MONTHLY. September/October 1971. Cited in: http://www.motherearthnews.com/realfood/sourdough-recipes-zmaz71sozgoe.aspx?PageId=1\#axzz3PehQPa71. [Accessed July 18, 2014].

ALLEN, J. 1978. American Society. New York: Linton Educational Publishing, 514 p. ISBN 0-27846072-0.

ALMOND BOARD OF CALIFORNIA. California Almond Industry Facts. In: https://www.almonds.com/sites/default/files/2016 almond industry factsheet.pdf. [Accessed February 17th, 2019].

ARISTOTLE. 1999. Nicomachean Ethics. Trans. Irwin, Terence. New York: Hackett Publishing, 1999. 480 p. ISBN-10 0872204642.

BARKER, C. 2006. Slovník kulturálních studií. Praha: Portál, 2006. 208 p. ISBN 80-7367-099-2.

BOURNE, J. 2018. "This Refuge May Be the Most Contested Land in the U.S." National Geographic. June 2018 issue. In:

https://www.nationalgeographic.com/magazine/2018/06/arctic-national-wildlife-refugeamerica-oil-risk/. [Accessed February 18th, 2019].

BRATTON, D. 1999. The 1999 American Food \& Travel Survey. San Francisco: The San Francisco Convention and Visitors Bureau.

BREALEY, N. 1994. Riding the Waves of Culture: Understanding the Cultural Diversity in Business. London: Fons Trompenaars, 1994. p. 21.

BYRAM, M. 1989. Cultural Studies in Foreign Language Education. Philadelphia: Multilingual Matters, In: http://www.carla.umn.edu/culture/resources/litreview.pdf. [Accessed July 1, 2013].

BYRAM, M. 1997. Teaching and Assessing Intercultural Communicative Competence. Clevedon: Multilingual Matters, 1997. pp. 34-73.

BYRAM, M.-MORGAN, C. et al. 1994. Teaching and Learning Language and Culture. Philadelphia: Multilingual Matters, 1994. pp. 50- 51.

CALIFORNIA DEPARTMENT OF FOOD \& AGRICULTURE. California Agricultural Production Statistics. In: https://www.cdfa.ca.gov/statistics. [Accessed Feb. 17th, 2019].

CHEN, C. 2020. Zumper National Rent Report: August 2020. In: https://www.zumper.com/blog/zumper-national-rent-report-august-2020/. [Accessed Aug. 26th, 2020].

CHEN, G. M.-STAROSTA, W. 2005. A Review of the Concept of Intercultural Awareness. In: Human Communication, 2005, 2, pp. 353-383.

CHENETIER, M. 2008. "New" American Studies: Exceptionalism redux? In: European Journal of American Studies. EJAS 2008-2. 
THE CHURCH OF JESUS CHRIST OF LATTER-DAY SAINTS NEWSROOM. Facts and Statistics - Utah. In: https://www.mormonnewsroom.org/facts-and-statistics/state/utah. [Accessed February 19th, 2019].

CODJOE, H. M. 2002. Can Blacks be Racist? In: Pens of Many Colours. Eva C. Karpinski (ed.). Scarborough: Thomson-Nelson, 2002.

COTHRAN, J. R. 2003. Gardens and historic plants of the antebellum South. Columbia, S.C.: University of South Carolina Press, 2003.

CRYSTAL, D. 1991. The Cambridge Encyclopaedia of Language. Cambridge: Cambridge University Press, 1991. 472 p. ISBN 0521559677.

DE AENLLE, CONRAD. 2015. Where Did Madoff's Money Go? In: Yale Insights, https://insights.som.yale.edu/insights/where-did-madoffs-money-go. [Accessed July 13, 2018].

DOUGLAS, G. H. 2004. Skyscrapers: a social history of the very tall building in America. Jefferson, N.C.: McFarland \& Co.

DOSSIER. 1994. The English-Speaking World-English Civilization. La Spiga Languages. 1994.

EDWARDS, T. (ed.) 2010. Kulturální teorie. Praha: Portál, 368 p. ISBN 978-80-7367-685-8.

ENDANGERED LANGUAGE ALLIANCE. Documentation. In: http://elalliance.org/programs/documentation/. [Accessed August 2, 2018].

FAIRVOTE. 2016. 2016 Presidential Candidate General Election Events Tracker. In: https://docs.google.com/spreadsheets/d/14Lxw0vc4YBUwQ8cZouyewZvOGg6PyzS2mArW Ne3iJcY/edit\#gid=0. [Accessed July 9, 2018].

FAOSTAT. 2013. Top 20 Commodities by country - Top production - World (Total) - 2012. In: http://faostat.fao.org/site/339/default.aspx. [Accessed July 18, 2014].

FAST FACT STUDY GUIDE. In: http://www.theus50.com/capital.php. [Accessed July 1, 2013].

FIEDLER, E.-JANSEN, R.-NORMAN-RISCH, M. 1994. America in Close-up. Singapore: Longman, 1994. 281 p. ISBN 0-582-74929-8.

FISCHER, D. H. 1989. Albion's Seed: Four British Folkways in America. Oxford University Press, 1989. ISBN-13 978-0-19-506905-1.

FISHER, A. 2018. Valley of Genius: The Uncensored History of Silicon Valley. Twelve, 2018. 512 p. ISBN 978-1455559022.

FRENCH, P. 2004. From Nighthawks to the shadows of film noir. In: The Observer, April 25, 2004, p. 7.

FRIES-BRITT, S. 1989. Some Things to Remember About Cross-Cultural Relationships. In Notes from lectures. p. 1.

GARDENSWARTZ, L.-ROWE, A. 1991. How Culturally Aware are You? In: The Diversity Tool Kit. London: Irwin Professional Publishing, Section III - 3.

GAZDÍK, M.-OTRÍSALOVÁ, L. 2012. English Canadian Literature in Slovak Translation: the story of underrepresentation. In: Canada in Eight tongues: translating Canada in central Europe. Brno: Masarykova univerzita, 2012. ISBN 978-80-210-5954-2.

GEROMETTA, M. et al. 2012. Tall Buildings in Numbers. In: The Council on Tall Buildings and Urban Habitat Journal. (2):48. 
GORDON, M. 2004. “The West and Midwest: Phonology.” In: A Handbook of Varieties of English, Vol. 1: Phonology, ed. Schneider et al. Mouton de Gruyter: 2004.

GUTMAN, R. 2000. American Diner: Then \& Now. Baltimore: Johns Hopkins University Press, $272 \mathrm{p}$.

HALL, S. 1980. Cultural Studies and the Centre: some problematics and problems. In: HALL, S. et al. (eds.) Culture, Media, Language. London: Hutchinson, 205 p.

HENČEKOVÁ, E. Vymedzenie kultúrneho obsahu učebníc anglického jazyka ako predpokladu pre medzikultúrny dialóg. pp. 214-220. In: http://www.pulib.sk/elpub2/FF/Olostiak1/pdf_doc/21.pdf. [Accessed July 10, 2013].

HOHN, E. 2004. Komparatistik im Kontext der literaturwissenschaftlichen Methoden. In: Zborník príspevkov zo VII. konferencie Spoločnosti učitel'ov nemeckého jazyka a germanistov Slovenska. Banská Bystrica 1.-4. 9. 2004, pp. 275-277. ISBN 80-89057-05-5.

HONG, J. 2013. Flat-panel TV Shipments Continue to Decline in July. IHS Technology. In: https://technology.ihs.com/454881/flat-panel-tv-shipments-continue-to-decline-in-july. [Accessed July 16, 2014].

HORNBY, A.S. 1989. Oxford Advanced Learner's Dictionary. 4th ed. Oxford: Oxford University Press, 1531 p. ISBN 0-19-431-510X.

HUDSON, J. 1994. Making the Corn Belt. Bloomington: Indiana University Press. 255 p. ISBN 0253-32832-2.

JAVORČÍKOVÁ, J. 2010. Literary and Cultural Artifact in the Process of Teaching. In: Philologica LXV. Bratislava: Univerzita Komenského FF UK, 2010. pp. 209-215. ISBN 978-80-2232894-4.

JAVORČÍKOVÁ, J. 2001. Word Perfect. Banská Bystrica: Metodické centrum, 2001. 33 p. ISBN 80-8041-396-7.

JESENSKÁ, P.-ŠTULAJTEROVÁ, A. 2013. Selected Chapters on English Lexical Semantics. Banská Bystrica: UMB, 137 p. ISBN 978-80-557-0486-9.

KAČALA, J. 1997. Krátky slovník slovenského jazyka. Bratislava : JULS, 943 p. ISBN 80-2240464-0.

KATZ, S. 2012. The Art of Fermentation. White River Junction, Vermont: Chelsea Green Publishing. $498 \mathrm{p}$.

KEMP, M. 2000. The Oxford History of Western Art. Oxford: Oxford University Press. 564 p.

KENT, M. 1997. Food and Fitness: A Dictionary of Diet and Exercise. Oxford: Oxford University Press, $377 \mathrm{p}$.

KOHLS, R. L. 2001. Survival Kit for Overseas Living. New York: Nicholas Bradley, 216 p. ISBN$1018578829 X$.

LADD, E. C. 1984. The Reagan Phenomenon and Public Attitudes Toward Government. In: Salamon, L.-Lund, M. (ed.) The Reagan Presidency and the Governing of America. Washington, D.C.: The Urban Institute, 1984. 500 p.

ŁUCZAJ, Ł. 2012. Ethnobotanical review of wild edible plants of Slovakia. In: Acta Societatis Botanicorum Poloniae. (4):81.

LUNGER, N. 1991. Business and Industry. In: About the United States. The United States Information Agency. $6 \mathrm{p}$. 
MATZ, M. 2008. Reálie Spojených států amerických. Plzeň: Fraus, 2008. 146 p. ISBN 978-80-7238 $-786-1$.

MAUK, D. C.-OAKLAND, J. 2005. American Civilization - An Introduction. New York: Routlege, 2005. 375 p. ISBN 0415 35831-0.

MCGEE, H. 2004. On Food and Cooking. New York: Scribner. 884 p.

METROPOLITAN LIFE INSURANCE COMPANY. 1914. The Metropolitan Life Insurance Company: its history, its present position in the insurance world, its home office building and its work carried on therein. New York: Metropolitan Life Insurance Co.

MIGRATION POLICY INSTITUTE. 2018. Mexican Immigrants in the United States. In: https://www.migrationpolicy.org/article/mexican-immigrants-united-states. [Accessed February 18th, 2019].

MOORE, J. 1991. An analysis of the cultural content of post-secondary textbooks for Spanish: Evidence of information processing strategies and types of learning in reading selections and post-reading adjunct questions. Unpublished doctoral dissertation. Minneapolis: University of Minnesota. In: http://www.carla.umn.edu/culture/resources/litreview.pdf [Accessed July 10, 2013].

MOUDRY, R. 2005. The American skyscraper: cultural histories. New York: Cambridge University Press.

MURPHY, R. 1986. Culture and Social Anthropology: An Overture. 2nd ed. New Jersey: Englewood Cliffs, Prentice Hall, 1986.

NATIONAL BASKETBALL ASSOCIATION. NBA Encyclopedia. Playoff Edition. "Michael Jordan" In: http://www.nba.com/history/players/jordan bio.htm. [Accessed August 3, 2018].

NATIONAL CORN GROWERS ASSOCIATION. Corn Usage by Segment 2017. In: http://www.worldofcorn.com/\#corn-usage-by-segment. [Accessed February 16th, 2019].

NATIONAL GEOGRAPHIC-GLOBESCAN. 2008. Greendex 2008: Consumer Choice and the Environment - A Worldwide Tracking Survey. National Geographic Society \& GlobeScan. In: http://images.nationalgeographic.com/wpf/media-live/file/GS_NGS_Full_Report_May08cb1274129241.pdf [Accessed September 10, 2013].

NATIONAL GEOGRAPHIC-GLOBESCAN. 2012. Greendex 2012: Consumer Choice and the Environment - A Worldwide Tracking Survey. National Geographic Society \& GlobeScan. In: http://images.nationalgeographic.com/wpf/mediacontent/file/NGS 2012_Final_Global_report_Jul20-cb1343059672.pdf. [Accessed September 10, 2013].

NAVAJO EPIDEMIOLOGY CENTER. 2013. Navajo Population Profile - 2010 U.S. Census. In: http://www.nec.navajo-nsn.gov/Portals/0/Reports/NN2010PopulationProfile.pdf. [Accessed February 18th, 2019].

NEWMAN, A. A. 2014. Trying to Bolster the Image of Frozen Meals as Sales Lag. The New York Times, April 24, 2014: p. B5.

OLVER, L. 2000. The Food Timeline. In: http://www.foodtimeline.org/foodfaq7.html. [Accessed July 22, 2014].

OTRÍSALOVÁ, L.-JAVORČÍKOVÁ, J. 2010. Slovakia and Canada: Bridging Two Nations: Foreword. In: Lopičić, V. (ed.) Migrating Memories: Central Europe in Canada. Volume 1 Literary Anthology. Brno/Niš: CEACS/AECEC, 327-386 p. ISBN 978-86-7746-233-8. 
OXFORD ENCYCLOPEDIA OF FOOD AND DRINK IN AMERICA, VOLUME 2. 2004. Oxford University Press: New York.

THE OXFORD ENCYCLOPEDIC ENGLISH DICTIONARY. 1991. Oxford: Clarendon Press.

OXFORD GUIDE TO BRITISH AND AMERICAN CULTURE. 2005. Oxford: Oxford University Press, 2005. ISBN-13978 0194311298.

PAIGE, R. M.-JORSTAD, H.-SIAYA, L.-KLEIN, F.-COLBY, J. Culture Learning in Language Education: A Review of the Literature. In: https://carla.umn.edu/culture/res/litreview.pdf. [Accessed September 7, 2021].

PAIGE, R. M. 1993. Education for Intercultural Experience. Yarmouth: ME Intercultural press, p. 171. In HENČEKOVÁ, E. 1993. Vymedzenie kultúrneho obsahu učebníc anglického jazyka ako predpokladu pre medzikultúrny dialóg. pp. 214-220. In: http://www.pulib.sk/elpub2/FF/Olostiak1/pdf_doc/21.pdf. [Accessed July 10, 2013].

PASSMARK SOFTWARE. AMD vs Intel Market Share. In: https://www.cpubenchmark.net/market_share.html. [Accessed February 19th, 2019].

PAWELEK, R. 1991. American Economy and Financial Institutions. In About the United States. The United States Information Agency. 6 p.

PETERSON, N. The Geography of Campaign Spending. In: https://liberal-arts.wright.edu/appliedpolicy-research-institute/blog/article/the-geography-of-campaign-spending. [Accessed July 9, 2018].

PEW RESEARCH CENTER. Republicans see too much regulation of financial industry, Democrats too little. In: http://www.pewresearch.org/fact-tank/2017/03/02/public-remainsdivided-over-role-of-government-in-financial-regulation/ft 17-03-02 financialreg party. [Accessed July 17, 2018].

POLLAN, M. 2006. The Omnivore's Dilemma. New York: Penguin. 451 p.

POSNER, R. 2012. In Defense of the Electoral College. In: http://www.slate.com/articles/news and politics/view from chicago/2012/11/defending the electoral_college.html. [Accessed July 10, 2018].

PRINCE, R. 2010. The Decline of European Home Cooking. In: The Wall Street Journal, Nov. 12, 2010, p. W8.

PRŠOVÁ, E. 2011. Humor v próze s detským a dospievajúcim chlapčenským hrdinom. In: Smiech, slzy a svet komiky. Ed. Ivan Jančovič. Banská Bystrica: UMB Fakulta humanitných vied, 2011. 368 s. ISBN 978-80-557-0147-9.

PURNELL, T. et al. 2009. "Defining Dialect, Perceiving Dialect, and New Dialect Formation: Sarah Palin's Speech.” In: Journal of English Linguistics. (4):37.

RAPINO, M., FIELDS, A. 2013. Mega Commuters in the U.S. Presented at the Association for Public Policy Analysis and Management Fall 2013 Conference.

RIVERNBURG, R. 2003. A landmark idea, yes, but whose? Tracing the invention of the TV dinner opens a can, er, tray of worms. The Los Angeles Times, November 23, 2014: p. E1 \& E4.

ROMBAUER, I.-ROMBAUER-BECKER, M.-BECKER, E. 1997. The All New Joy of Cooking. New York: Scribner. $1136 \mathrm{p}$.

SAMOVAR, A. L.-PORTER, E. R. 2001. Communication between Cultures. 4th edition. Belmont: Wadsworth, 2001. 277 p. 
SCOTT, J. 2010. Kulturální analýza v marxistickém humanizmu (Cultural Analysis In Marxist Humanism). In: EDWARDS, T. (ed.) 2010. Trans. Vichnar, David. Kulturální teorie. Praha: Portál, 368 p. ISBN 978-80-7367-685-8.

SCOTT, J. 2010. Giddens a kulturální analýza: nepřítomné slovo a ústřední concept (Giddens and Cultural Analysis - Absent Word and Central Concept). In: EDWARDS, T. (ed.) 2010. Kulturální teorie. Trans. Vichnar, David. Praha: Portál, 368 p. ISBN 978-80-7367-685-8.

SMITH, L. et al. 2013. Trends in US home food preparation and consumption. In: Nutrition Journal. 2013, 12:45.

SMITH, S. 2011. Moon Nevada. New York: Perseus Book Group, 440 p. ISBN 978-1598807578.

SOULE, D. C. 2006. Urban sprawl: a comprehensive reference guide. Westport, Conn.: Greenwood Press.

SULLIVAN, L. H.-BRAGDON, C. F. 1924. The Autobiography of an Idea. New York: Press of the American Institute of Architects.

TIERSKY, E.-TIERSKY, M. 1975. USA - Customs and Institutions. New York: Regents, 273 p.

THOMPSON, NEAL. 2007. Driving with the Devil: Southern Moonshine, Detroit Wheels, and the Birth of NASCAR. Broadway Books, 2007. ISBN-13: 978-1400082261.

TRUFELMAN, AVERY. 2018. "Hawaiian Shirts: Articles of Interest \#4." 99\% Invisible. In: https://99percentinvisible.org/episode/hawaiian-shirts-articles-of-interest-4/. [Accessed November 20th, 2018.]

TYSON FOODS. 2014. Family Meal Time Survey. In: http://www.tysonfoods.com/ourstory/families.aspx. [Accessed July 22, 2014].

UNESCO DEFINITION OF CULTURE. 2005. UNESCO and the Question of Cultural Diversity 1946-2007. Review and Strategies. In: http://unesdoc.unesco.org/images/0015/001543/154341mo.pdf. [Accessed July 10, 2013].

UNIVERSITY OF CALIFORNIA MUSEUM OF PALEONTOLOGY. Artificial Selection. In: Understanding Evolution. http://evolution.berkeley.edu/evolibrary/images/evo/mustardselection.jpg. [Accessed July 21, 2014].

U.S. CENSUS BUREAU. 2004. Ancestry: 2000. In: https://www.census.gov/history/pdf/ancestry.pdf. [Accessed February 6th, 2019].

U.S. CENSUS BUREAU. 2011. Native North American Languages Spoken at Home in the United States and Puerto Rico: 2006-2010. In: https://www2.census.gov/library/publications/2011/acs/acsbr10-10.pdf. [Accessed February 18th, 2019].

U.S. CENSUS BUREAU. 2013. US and World Population Clock. p. 1. In: http://www.census.gov/popclock/. [Accessed July 12, 2013].

U.S. CENSUS BUREAU. 2018a. National Population Totals and Components of Change: 20102018. In: https://www.census.gov/data/tables/time-series/demo/popest/2010s-nationaltotal.html. [Accessed February 6th, 2019].

U.S. CENSUS BUREAU. 2018b. QuickFacts - Alaska. In: https://www.census.gov/quickfacts/fact/table/ak/PST045218\#viewtop. [Accessed February 18th, 2019]. 
U.S. DEPARTMENT OF AGRICULTURE, ECONOMIC RESEARCH SERVICE. 2014. U.S. domestic corn use. In: http://www.ers.usda.gov/media/866543/cornusetable.html. [Accessed July 21, 2014].

U.S. DEPARTMENT OF COMMERCE. 2017. 2017 Top Markets Report Media and Entertainment Sector Snapshot. In:

https://www.trade.gov/topmarkets/pdf/Top\%20Markets\%20Media\%20and\%20Entertinment \%202017.pdf. [Accessed February 18th, 2019].

U.S. DEPARTMENT OF TRANSPORTATION, FEDERAL HIGHWAY ADMINISTRATION. 1973. Nationwide Personal Transportation Study, report no. 8: Home-to-Work Trips and Travel.

U.S. OFFICE OF TECHNOLOGY ASSESSMENT. 1994. Saving energy in U.S. transportation. Washington, DC: Congress of the U.S.

U.S. SOYBEAN EXPORT COUNCIL. Uses for Soybeans. In: https://ussoy.org/uses-for-soybeans/. [Accessed February 16th, 2019].

USIA. 1991. United States Information Agency. pp. 1-4.

VANCE, J. D. 2016. Hillbilly Elegy: A Memoir of a Family and Culture in Crisis. Harper, 2016. ISBN-10: 0062300547.

WALLIN, N. 2004. Chili: Small Fruit Sets Global Palettes on Fire. In: YaleGlobal. http://yaleglobal.yale.edu/about/chili.jsp. [Accessed July 18, 2014].

WELCH'S. 2013. State of the American Family: Mealtime a Top Priority. In: http://www.welchs.com/docs/default-source/health-andnutrition/welchs kitchen table report.pdf?sfvrsn=0. [Accessed July 22, 2014].

WHAT IS CULTURE? 2013. (Anonymous). In: http://en.wikipedia.org/wiki/Culture. [Accessed July 20, 2013].

WISEMAN, L. R. 2001. Intercultural Communicative Competence. 2001. In: http://commfaculty.cullerton.edu/rwiseman/ICCCpaper.htm. [Accessed May 10, 2013].

WITZEL, M. 2006. The American Diner. St. Paul: MBI, 160 p.

WOODARD, COLIN. 2011. American Nations: A History of the Eleven Rival Regional Cultures of North America. Penguin Books, 2011. ISBN 978-0-14-312202-9.

WORLD WILDLIFE FOUNDATION. 2014. The Growth of Soy: Impacts and Solutions. Gland, Switzerland: WWF International. $94 \mathrm{p}$.

YODER, D. 1972. Folk Cookery. In: DORSON, R. M. (ed.) 1972. Folklore and Folklife, An Introduction. Chicago: University of Chicago Press, $561 \mathrm{p}$.

ZELENKA, I. 2007. Languagewise or Culturewise? - k poslaniu literárneho textu na hodinách cudzieho jazyka. In Pedagogické rozhl'ady. 4(16). Banská Bystrica: MPC, 2007. 32 p. ISSN 1335.0404 .

ZELENKOVÁ, A. 2009. Interkultúrne vzdelávanie ako súčast' cudzojazyčnej výučby na vysokej škole. In: Psychologie, Sociologie a Pedagogika. Mezinárodní Batova conference pro doktorandy a mladé vědecké pracovniky. Zlín: Univerzita Tomáše Bati ve Zlíne, 2009. ISBN 978-80-7318-812-2. 


\section{About the authors:}

Jana Javorčíková has worked at the Department of English and American Studies in Banská Bystrica, Slovakia, since 1997. She specialises in the literatures and cultures of the Englishspeaking countries (she currently teaches courses in American studies, Canadian studies, modern and 17th-to-19th-century English literature and selected courses in American drama and literature). Her recent publications include a coursebook of English literature entitled Contemporary Literature in English: Selected Historical, Social and Cultural Contexts (2012), a two-volume reader on Canadian literature entitled Slovak Immigration to Canada: Narrated Histories and Written Histories (2010). She has also published widely in the fields of American studies and literature. In 2005-2006, she spent a year teaching literature and culture at Minneapolis Community and Technical College in Minneapolis, Minnesota.

Michael E. Dove has worked at Matej Bel University's Department of English and American Studies since 2008. His teaching activities focus on written and spoken rhetoric, translation, and naturally American studies, in which he co-teaches a course with Dr. Javorčíková. Michael was born and raised near Boston, Massachusetts. 


\section{Explorations in American Life and Culture}

2021

Authors: PaedDr. Jana Javorčíková, Ph.D.

Mgr. Michael E. Dove

Reviewers: prof. Ruslan Saduov, Ph.D.

doc. PhDr. Anna Zelenková, Ph.D.

Richard Amidon Betts, Ph.D.

Consulted experts: Mgr. Ivan Zelenka (The Composition of US

Society), Mgr. Mikuláš Gürtler (The Legal System), Richard A. Betts, Ph.D.,

Michael Seward, Ph.D. (The Political System), Mgr. Michael E. Dove (The School

System), Sandra Hall, Ph.D. (The School System)

Cover design: Karol Demuth

Cover photograph: (C) Charles Hészely (Downtown Minneapolis)

Copyediting: Michael E. Dove; Chapters 2 \& 11: Paul Wood, Gloria M. Dove

Layout \& typesetting: Karol Demuth

Edition: 3rd edition, 1st electronic edition

Page count: 236

Format: A4

Publisher: Belianum: Matej Bel University Press

Publication year: 2021

ISBN 978-80-557-1860-6

DOI https://doi.org/10.24040/2021.9788055718606

(C) Javorčíková - Dove, 2021 